UNIVERSIDADE DE SÃO PAULO

FACULDADE DE EDUCAÇÃO

DARCISIO NATAL MURARO

A importância do conceito no pensamento deweyano:

relação entre pragmatismo e educação

São Paulo - SP 


\section{A importância do conceito no pensamento deweyano: relação entre pragmatismo e educação}

Tese apresentada à Comissão Julgadora
do Programa de Pós Graduação da
Faculdade de Educação da Universidade
de São Paulo, como exigência parcial
para obtenção do título de doutor em
Educação.
Área de concentração: Filosofia da
Educação.
Orientadora: Prof ${ }^{\text {a }}$. Dra ${ }^{a}$. Maria Nazaré de
Camargo Pacheco Amaral 
Autorizo a reprodução e divulgação total ou parcial deste trabalho, por qualquer meio convencional ou eletrônico, para fins de estudo e pesquisa, desde que citada a fonte.

Catalogação na Publicação

Serviço de Biblioteca e Documentação

Faculdade de Educação da Universidade de São Paulo

\section{$37.01 \quad$ Muraro, Darcísio Natal}

M972i A importância do conceito no pensamento deweyano: relações entre pragmatismo e educação / Darcísio Natal Muraro; orientação Maria Nazaré de Camargo Pacheco Amaral. São Paulo: s.n., 2008.

$228 \mathrm{p}$.

Tese (Doutorado - Programa de Pós-Graduação em Educação. Área de Concentração: Filosofia da Educação

- Faculdade de Educação da Universidade de São Paulo

1. Dewey, John 2. Pragmatismo 3. Conceitos - Processos Cognitivos 4. Educação 5. Democracia 6. Pensamento

I. Amaral, Maria Nazaré de Camargo Pacheco, orient. 


\section{FOLHA DE APROVAÇÃO}

\section{Darcísio Natal Muraro}

A importância do conceito no pensamento deweyano: relação entre pragmatismo e educação

Tese apresentada à Comissão Julgadora do Programa de Pós Graduação da Faculdade de Educação da Universidade de São Paulo, como exigência parcial para obtenção do título de doutor em Educação.

Área de concentração: Filosofia da Educação.

Aprovado em:

Banca Examinadora

Prof. Dr.

Instituição Assinatura

Prof. Dr.

Instituição Assinatura

Prof. Dr.

Instituição Assinatura

Prof. Dr.

Instituição Assinatura

Prof. Dr.

Instituição Assinatura 


\section{DEDICATÓRIA}

Á Ana Cristina Guimarães, pela compreensão, amor e apoio intenso que deram leveza e força para a continuidade do trabalho.

Á Helen Cristina Guimarães Muraro: vida nova que chegou durante este trabalho, sinal de ternura, graça, inspiração, alegria e esperança em nossas vidas. 


\section{AGRADECIMENTOS}

À professora Dr $^{\mathrm{a}}$ Maria Nazaré de Camargo Pacheco Amaral, pela orientação paciente e confiante, pelas oportunidades de reflexões e pelo contínuo apoio, sem o que este trabalho não teria sido realizado.

Ao professor Dr. Ivo Assad Ibri pelas importantes sugestões dadas para a ampliação do trabalho.

Ao professor José Auri Cunha, pela colaboração intensa na problematização de questões da tese, pelo trabalho de revisão e pela especial amizade.

À Jaqueline Sampaio, pela revisão técnica do trabalho.

À Márcia Heloisa Sampaio, pela leitura paciente e contribuições na revisão.

As pessoas que colaboraram na tradução ou revisão de alguns trechos utilizados neste trabalho:

Nélia Maria Pinheiro Padilha Von Tempski-Silka

Denise Monteiro.

À $\operatorname{Dr}^{\mathrm{a}}$ Helen Anne Butler Muralha, pelo carinhoso apoio material e emocional, pelo amor e amizade.

Ao amigo Eliezer Milesere, pelas discussões e especial apoio encurtando distância.

Aos meus familiares, com muito carinho, especialmente à minha mãe e meu pai: Leocádia Mocelin Muraro e Amado Muraro.

A todas as pessoas e instituições que de alguma forma contribuíram com sua amizade e apoio para a realização deste trabalho. Destaco alguns nomes:

Andréa Prendin

Cassiano Rodrigues Terra. 
Celi Lopes de Moraes

Eliane Aparecida M. Pires

Flaviana Martins de Lima

Francisco Ximenez

Ismael de Oliveira

João Bosco Fernandes

Jorge Alves

Josué Cândido da Silva

Márcia Heloisa Sampaio

Marcos Antonio Lorieri

Marlete Scapinelli

Michele Czaikoski

Neusa M. Pita de Sousa

Orlando Araújo Bonafé

Patrícia Helena Rocha

Paula Ramos de Oliveira

Priscylla Krone

Rejane Giacomassi

Rita de Cássia Gonçalves de O. Angerami

Thaís M. Kuzma

Aos alunos de todas as turmas do curso Fundamentos de uma Educação para o Pensar (PUCSP, PUCMG - Poços de Caldas) pela oportunidade de ler e dialogar as idéias de John Dewey

A todos, muito obrigado. 
Com suas congêneres, vida e história, a experiência inclui aquilo que os homens fazem e padecem, aquilo que eles se esforçam por conseguir, amam e crêem, e talvez como os homens agem e sofrem a ação, as maneiras pelas quais eles realizam e padecem, desejam e desfrutam, vêem, crêem, imaginam - em suma, processos de experienciar. "Experiência” designa o campo plantado, as sementes semeadas, as searas ceifadas, as alternâncias entre noite e dia, primavera e outono, úmido e seco, calor e frio, que são observados, temidos, ardentemente desejados; designa também aquele que planta e colhe, que trabalha e se alegra, espera, teme, planeja, invoca a magia ou a química em busca de auxílio, que é vencido ou triunfante. Ela é “de duplo sentido" nisto em que, em sua integridade primitiva, não admite divisão entre ato e matéria, sujeito e objeto, mas os contém numa totalidade não analisada. 


\section{RESUMO}

MURARO, D. N. A importância do conceito no pensamento deweyano: relação entre pragmatismo e educação. 2008. 228p. Tese (Doutorado). Faculdade de Educação, Universidade de São Paulo, São Paulo, 2008.

Dewey desenvolve a teoria instrumental e operacional dos conceitos para explicar a forma inteligente do homem de conduzir sua experiência natural, social, cultural e democrática. $\mathrm{O}$ pragmatismo de Dewey compreende os conceitos como instrumentos que o pensamento reflexivo utiliza no processo da investigação para transformar uma situação problemática, inicialmente confusa e não dirigida em uma situação resolvida, harmoniosa como forma de garantir a permanente necessidade de adaptação do indivíduo ao meio, garantindo assim a sua sobrevivência. Os conceitos como instrumentos de significação ou instrumentos para estabelecer relações de continuidade entre meios e fins na e para a experiência têm a função de guiar a ação inteligente do ser humano. A solução experimental que resolve uma situação problemática é chamada de "asserção garantida". Aquilo que é verdadeiro somente pode ser compreendido a partir das conseqüências práticas de um conceito cujos significados foram elaborados no processo investigativo. O estudo dos métodos para resolver problemas, Dewey chamou de lógica, ou teoria da investigação. Esta é histórica e evolutiva. Os conceitos são instrumentos sociais de comunicação dos significados da experiência através da linguagem e instrumentos que corroboram no processo investigativo. A aquisição destes instrumentos deve ser estimulada pela educação. A escola é o ambiente organizado e simplificado para a formação do hábito de pensar que ganham força no âmbito de uma sociedade democrática. A fé na vida democrática fundamenta-se na fé nas capacidades da natureza humana com necessidade inata de associação, cooperação e uso da inteligência humana na solução dos conflitos sobre bens sociais. A vida democrática é a que oferece as melhores oportunidades para o crescimento, uma vez que desperta naturalmente o interesse pela solução dos conflitos numa comunidade de comunicação. Constituindo-se, assim, a vida democrática é a única forma de vida digna dos seres humanos.

Palavras chave: Dewey. Pragmatismo: conceitos, educação, democracia, pensamento. 


\begin{abstract}
ABSTRATCT
MURARO, D. N. The importance of concepts in the Dewean thinking: relations between Pragmatism and the education. 2008. 228 f. Thesis (Doctoral). Faculdade de Educação, Universidade de São Paulo, São Paulo, 2008

Dewey develops the instrumental and operational theory of concepts, in order to explain man intelligent form of conducting his natural, social, cultural and democratic experience. Dewey's pragmatism comprehends the concepts as instruments the reflexive thought uses in the process of investigation, to transform a problematic situation, initially confuse and not commanded, in a resolved and harmonic situation, as a way to grant the permanent need for adaptation to environment by the individual, therefore granting him the survival. The concepts as instruments of signification or instruments for the establishment of relations of continuity between means and purposes in and for the experience have the function of guiding the intelligent action of the human being. The experimental solution that solves a problematic situation is called the "warranted assertion". What is true to life can only be understood from the practical consequences of a concept, whose meanings were elaborated in the investigative process. Dewey called logic or theory of investigation the study of the methods to solve problems. The logic is historical and evolutive. The concepts are social instruments of communication of the meanings of the experience through language and instruments that corroborate in the investigative process. The acquisition of these instruments shall be stimulated by education. The school is the organized and simplified environment for the development of the habit of thinking, which urges in the ambit of the democratic society. Faith in the democratic life is founded on faith in the capacities of human nature with the innate necessity of association, cooperation and use of human intelligence in the solution of the conflicts over social assets. Democratic life is the one to offer the best opportunities for growth, once it naturally awakes the interest on the solution of conflicts in a communication community. Thus constituted, democratic life is the only form of life that is condign for human beings.
\end{abstract}

Key Words: Dewey, Pragmatism, concepts, education, democracy, thinking 


\section{SUMÁRIO}

INTRODUÇÃO . $\quad . \quad$.

CAPÍTULO I - O PRAGMATISMO AMERICANO • $\quad$ • $\quad$ • $\quad 18$

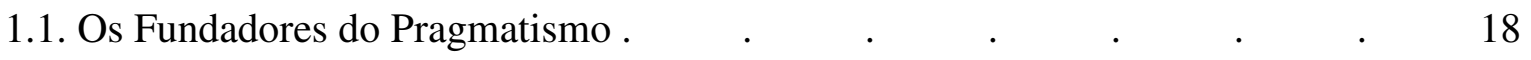

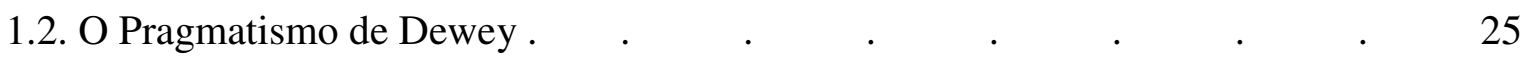

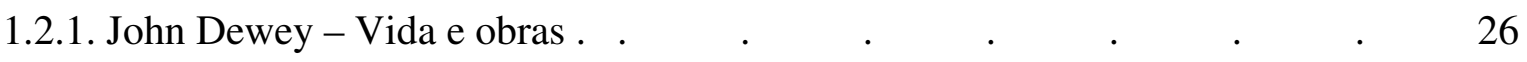

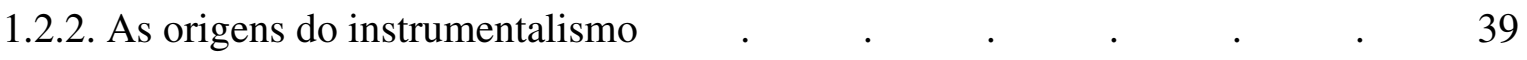

CAPÍTULO II - A CONCEPÇÃO DE CONCEITO EM DEWEY • • • $\quad 48$

2.1. As relações entre o conceito, a experiência e a natureza . 48

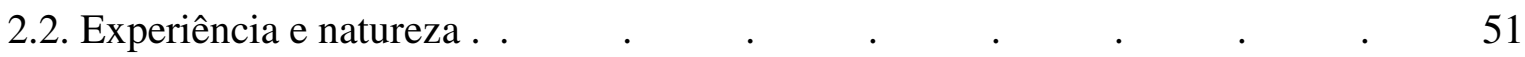

2.3. Conceito na concepção naturalista: natureza e instrumentos. • 70

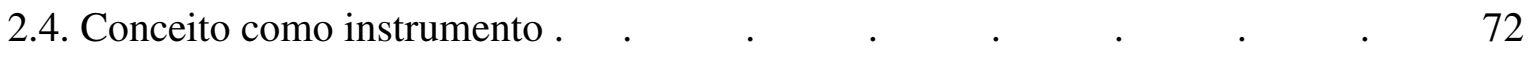

2.5. Conceito e organismo: crítica ao dualismo mente e corpo . 77

2.6. Conceitos na concepção naturalista: continuidade e interação entre meio e organismo .

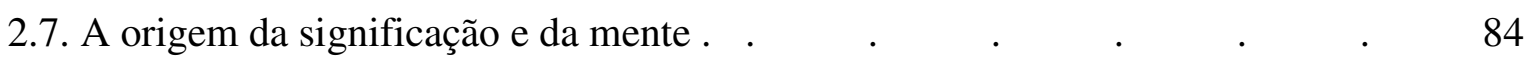

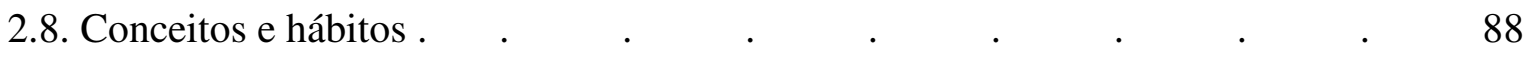

2.9. A origem biológica dos conceitos como instrumentos de significação $\quad$ $\quad 101$

2.10. O papel dos conceitos na investigação experimental . $\quad . \quad . \quad . \quad . \quad 103$

CAPÍTULO III - CONCEITO E SUA FUNÇÃO SOCIAL - PENSAMENTO REFLEXIVO E A TEORIA LÓGICA DA INVESTIGAÇÃO • • • • 115

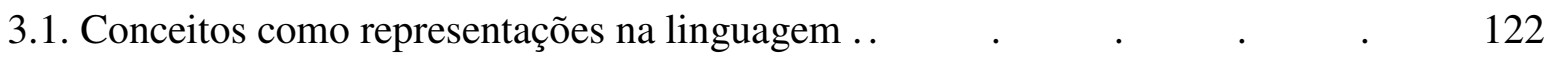

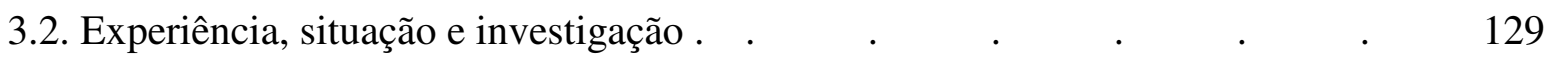

3.3. O papel do conceito na pauta da investigação . . $\quad . \quad$. $\quad . \quad$. $\quad$. 131

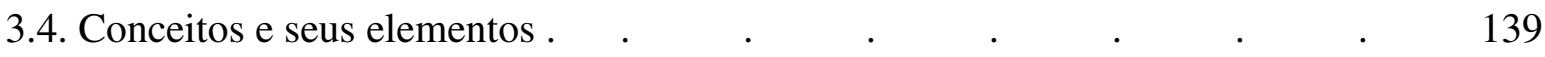

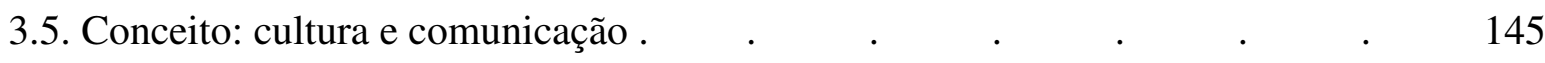

3.6. A democracia e a reconstrução social dos conceitos e da inteligência . $\quad$ $\quad 156$

CAPÍTULO IV - CONCEITO E EDUCAÇÃO • • • • • • • 163

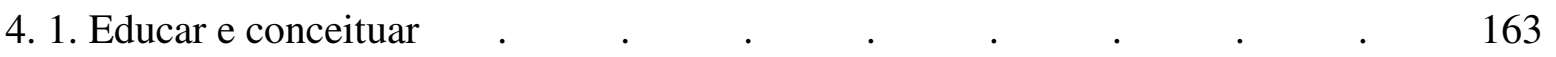




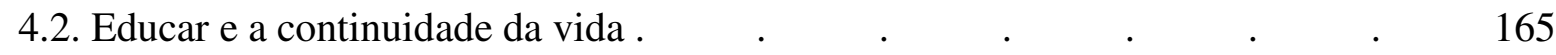

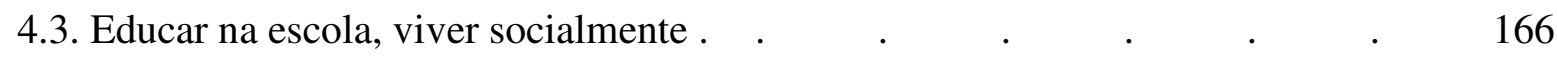

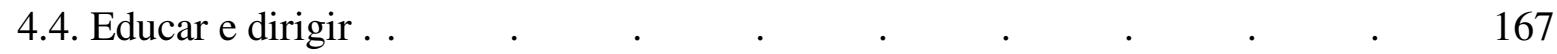

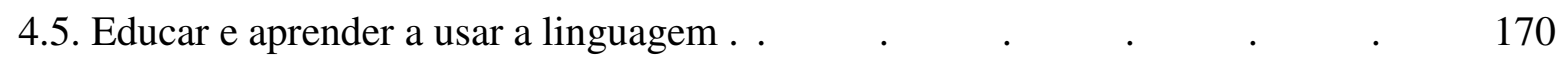

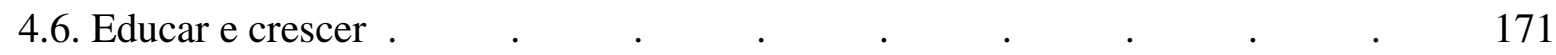

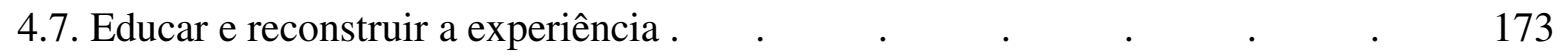

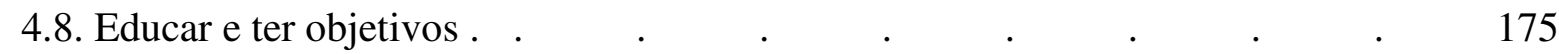

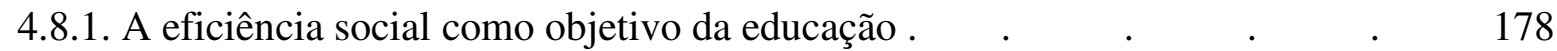

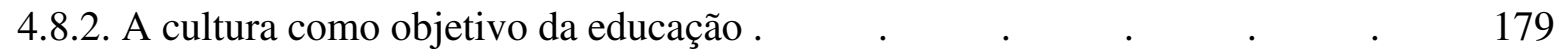

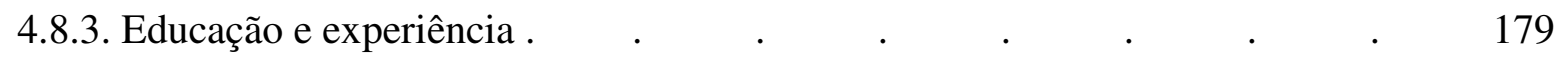

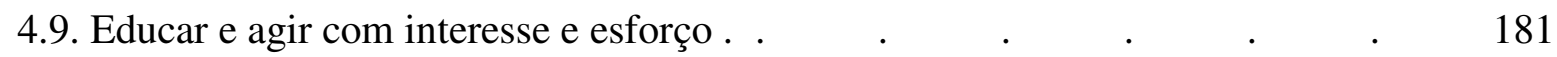

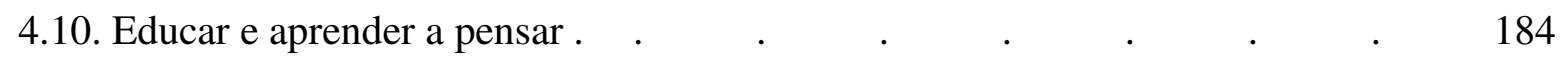

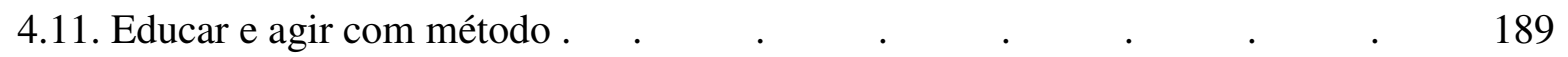

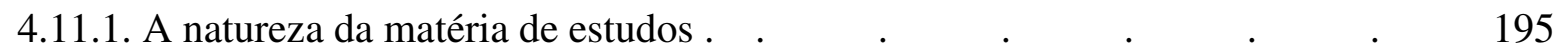

4.11.2. A matéria de estudo em sua natureza social . $\quad$. . 200

4.12. Educar é respeitar a vida da criança: corpo, imitação, brinquedo e trabalho . $\quad 201$

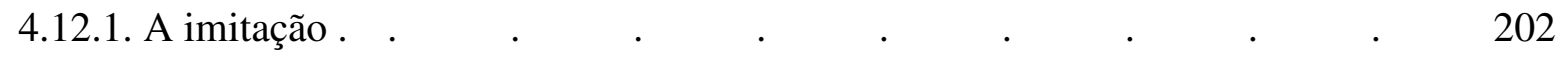

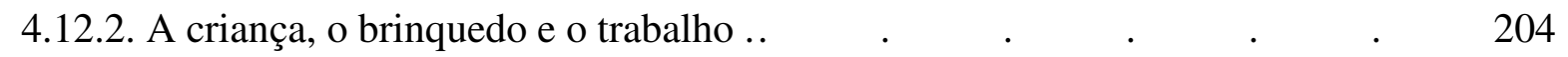

4.13. Educar e escolher as atividades educativas . . . . . . . . $\quad$. 209

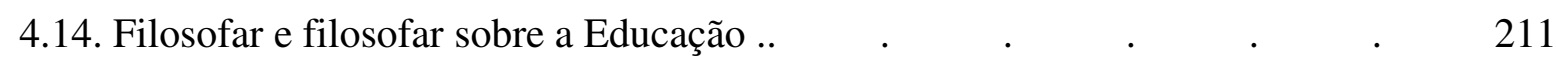

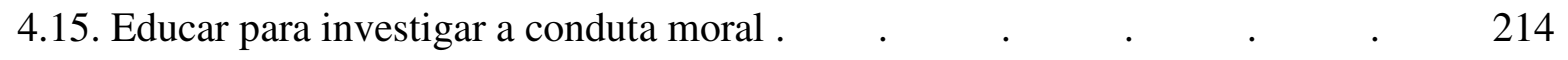

CONSIDERAÇÕES FINAIS $\quad$ • $\quad$ •

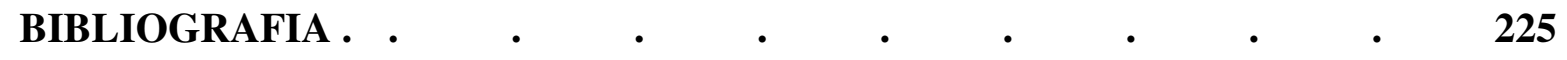




\section{INTRODUÇÃO}

As primeiras palavras não são as mais fáceis de serem ditas, principalmente quando elas vêm quase por último e com a delicada tarefa de ser um convite para entrar na casa recém-construída.

Com a chegada dos convidados, as portas e janelas se abrem para que, inundados pela luz, possamos ver tudo em seus mínimos detalhes.

Falar dos detalhes pode ofuscar os cenários mais belos e talvez mais importantes, para não dizer desde já a palavra, úteis. Mas, observar detalhes pode ajudar a ver melhor o todo.

O todo ao qual nos referimos pode ser simbolizado por este trabalho, se considerarmos que ele é entrecortado por diversos níveis.

Um primeiro grupo de detalhes está no nível da vida concreta, de um pesquisador concreto. Ao abrir o álbum de fotos desta trajetória, nos deparamos com aquelas fotos que sobrecarregam a mala e aquelas que mostram o presente. A mala é o peso das inúmeras e longas viagens, dos livros, do próprio labor para o auto-sustento pessoal, custeio do estudo e manutenção da família. O presente é o encontro com amigos novos e antigos, professores, idéias e, de maneira especial, uma esposa e uma filha recém-nascida.

Um segundo conjunto de detalhes está no nível da vida acadêmica propriamente dita. E aqui temos coisas interessantes para pôr em cima da mesa. Algumas trágicas, como a que se refere à negação de bolsa de estudos pelas agências de fomento à pesquisa, tão necessária para este tipo de empreendimento. Consideremos seriamente este problema: as obras de Dewey não estão facilmente disponíveis em português; as poucas traduções que dispomos estão esgotadas no mercado editorial e sem previsão de reedição; são traduções que apresentam sérios problemas; as obras completas do autor, no original, não se encontram em nenhuma biblioteca brasileira, entre as consultadas. Nossa única alternativa, para um trabalho criterioso, foi adquirir os livros do autor no mercado externo, procedimento demorado, dispendioso e com inúmeros contratempos. 
Dewey é considerado um autor clássico ${ }^{1}$ da filosofia, da psicologia social e da educação. Está no rol dos princípios acadêmicos o compromisso de proporcionar a leitura dos clássicos. Porém, no que se refere a Dewey, temos sérias limitações, uma vez que nem obras principais do autor, como Logic. The Theory of Inquiry, estão traduzidas. Para termos uma melhor dimensão do problema, comparemos, por exemplo, a abundante publicação das obras de autores importantes para a psicologia e educação, como J. Piaget, L.S.Vygotsky, A. Lúria.

Cabe registrar o caminho percorrido para a escolha de dedicar-me ao estudo deste autor, primeiramente no Mestrado, e agora neste Doutorado. Primeiramente, vale mencionar as motivações pessoais. Retornemos no tempo para encontrar os meus primeiros contatos com o pensamento deweyano. O currículo do curso de graduação de Filosofia que freqüentei estava estruturado inteiramente sobre a filosofia européia. Oferecia também algumas poucas disciplinas pedagógicas, também centradas sobre os pedagogos europeus, mas com algumas leituras sobre a história da educação brasileira, como o movimento da Escola Nova, liderada por Anísio Teixeira, Fernando Azevedo, Lourenço Filho, além da menção a outros pedagogos contemporâneos, especialmente Paulo Freire. O contato com o pensamento de Paulo Freire, ele ainda era vivo, e seu embate com a ditadura, despertou em mim simpatia significativa, a ponto de ser objeto do trabalho de conclusão do curso. A referência direta ou indireta destes autores ao pensamento deweyano, especialmente aos problemas da democracia, da prática da liberdade, do pensamento reflexivo, suscitou forte interesse por este autor, que ficou anotado como uma tarefa de continuidade de estudo. Estes assuntos adquiriam especial importância no contexto histórico de fim da ditadura militar e exigiam busca de fundamentos que alimentassem um debate mais consistente. Entretanto, a leitura dos filósofos americanos era desmotivada, tanta pela crítica ao imperialismo americano e a cultura "enlatada", quanto pela forte tendência marxista na academia, que inclusive exercia também sobre mim especial simpatia intelectual e política.

O mestrado foi a forma encontrada para aprofundar estas discussões e a decisão foi a de levar adiante um estudo mais apurado da obra Como pensamos, de John Dewey. Essa pesquisa mostrou, no entanto, a necessidade de continuar aprofundando mais ainda a vasta obra do autor.

\footnotetext{
${ }^{1}$ Tomamos o termo clássico nas várias acepções dadas por Ítalo Calvino, na obra Por que ler os clássicos. (2004)
} 
À medida que foi avançando minha leitura da obra de John Dewey, deparei-me com um campo vasto de concepções novas, como, por exemplo, o pensar / pensamento reflexivo como princípio educativo, a concepção social de homem e da escola, a importância da democracia em todas as esferas da vida, a necessidade da prática como forma de adquirir conhecimentos, a continuidade experiência e a formação das significações, o aprender a aprender a pensar, a ética investigativa, a reconstrução da Filosofia, as relações entre natureza e cultura, dentre tantos outras. O desafio foi o de encontrar um eixo unificador a partir do qual pudesse investigar e apreender com mais profundidade o pensamento deweyano. Percebi que, como é comum a cada filósofo, o elo de ligação da rede de idéias elaboradas pelo autor é sua própria concepção de conceito. Fazia sentido olhar a obra do autor sob este foco, a fim de encontrar uma imagem mais original.

O fato de que John Dewey tenha se tornado uma referência na história da filosofia e da educação norte-americana ganhou outra dimensão após o contato com sua obra. Seu pensamento demonstra envergadura e originalidade, não somente por ser considerado um dos fundadores do pragmatismo juntamente com outros dois pioneiros, que são C. S. Peirce e W. James, mas por ter desenvolvido reflexões que perpassam todos os campos da filosofia e da educação. Seu pensamento é cada vez mais reconhecido como clássico, por continuar ainda a iluminar o debate atual destas duas áreas de grandioso valor para a cultura humana.

A filosofia deweyana entrou em relativo declínio nos Estados Unidos com o desenvolvimento intenso da Filosofia Analítica, introduzida pelos "positivistas lógicos", fugidos do nazismo e que ali aportaram, a partir dos anos 30, e acabaram dominando a maioria dos departamentos de filosofia. Existe hoje um movimento de retomada do pensamento pragmatista deweyano, impulsionado em grande parte pelo neopragamatismo de Richard Rorty. Foi Rorty quem empreendeu novo interesse pela atualidade das idéias de John Dewey, inclusive colocando-o, junto com Wittgenstein e Heidegger, no grupo do que considera os três filósofos mais importantes do século passado. Nas palavras de Rorty:

É de encontro com este fundo que devemos encarar a obra dos três mais importantes filósofos de nosso século - Wittgenstein, Heidegger e Dewey. Cada um deles tentou, na sua juventude, encontrar uma nova maneira de tornar a filosofia "fundamental" - uma nova maneira de formular um contexto último para o pensamento. Wittgenstein procurou construir uma nova teoria da representação, que nada teria a ver com o mentalismo. Heidegger tentou construir um novo conjunto de categorias filosóficas que nada teriam a ver com a ciência, a epistemologia, ou a busca cartesiana da certeza, e Dewey tentou construir uma nova versão naturalizada da visão hegeliana da história. [...] Todos os três, nas suas últimas obras, se libertaram da concepção kantiana da filosofia como fundamento e dedicaram 
o seu tempo a prevenir-nos contra aquelas mesmas tentações a que eles próprios haviam um dia sucumbido. Essas últimas obras são assim mais terapêuticas do que construtivas, mais edificantes do que sistemáticas, concebidas de molde a que o leitor questione os seus motivos para filosofar, em vez de lhe fornecer um novo programa filosófico. (Rorty, 1988. p. 16 e 17, itálicos nossos)

A obra de Rorty, A Filosofia e o espelho da natureza é um marco significativo de tentativa de retomada do pensamento deweyano. Com a repercussão da obra de Rorty e sua atuação no debate filosófico atual, Dewey ganhou também a atenção de outros filósofos consagrados e mundialmente conhecidos como Jacques Derrida e Jürgen Habermas. Este também tem declarações importantes, como leitor dos pragmatistas pioneiros, no processo de construção de suas teses:

Estimulado por meu amigo Apel, também estudei Peirce, bem como Mead e Dewey. Desde o início entendi o pragmatismo americano como sendo a terceira resposta produtiva a Hegel, depois de Marx e Kierkegaard, por assim dizer como o ramo democrático-radical do neo-hegelianismo. Desde então me apóio nesta variante da filosofia da práxis, quando surge o problema de compensar a debilidade do marxismo com relação à teoria democrática. (Habermas, 1987. p. 78-79, itálico nosso)

A necessidade de estudar o pensamento deweyano está amparada na relevância atual de suas idéias para as práticas da filosofia e da educação mundial, como mencionamos. $\mathrm{O}$ recorte que leva à leitura da produção deste autor põe foco na dimensão por ele dada aos conceitos. O objeto da pesquisa é a concepção de conceito em sua filosofia e os desdobramentos para a concepção de educação. Assim, o estudo se propõe a oferecer elementos para o debate sobre a concepção de conceito, questão que consideramos relevante tanto para a filosofia quanto para a educação.

Esta pesquisa tem também outra razão bastante forte e que se assenta na relevância da influência das idéias deweyanas na filosofia da educação brasileira. Pesquisar Dewey a partir deste contexto permite entender e contribuir com a leitura que se fez e se faz de seu pensamento e oferecer luzes para uma compreensão mais fidedigna e um posicionamento crítico.

Finalmente, esta pesquisa pretende oferecer fundamentos teóricos para a abordagem dos problemas da filosofia e da educação relacionados ao pensamento deste autor nas diversas atividades de formação de professores e da pesquisa.

O problema, portanto, que essa tese se propõe a investigar é a concepção de conceito na filosofia deweyana e suas relações com o pragmatismo e com a educação. 
O objetivo foi o de entrar na obra do autor para desenvolver as seguintes questões:

1. O que Dewey entende por conceito? Como essa questão aparece em sua obra? Como se dá a construção deste tema: sua origem, princípios, categorias, influências e conceitos relacionados? Qual o papel que exerce na sua reconstrução filosófica?

2. A concepção de conceito no pensamento deweyano e suas implicações educacionais. Como o conceito aparece em sua teoria da educação? Como pensa a dimensão didático-pedagógica do conceito na relação ensino-aprendizagem?

Dewey reconstrói uma vasta rede de princípios e conceitos para formular sua filosofia, como por exemplo, o princípio de continuidade e interação, os conceitos de experiência, natureza, pensamento, conceito, conhecimento, lógica, investigação, hábito, democracia, educação, interesse e esforço, dentre outros. Esta é a tarefa que o próprio Dewey busca empreender em suas obras: "É uma questão urgente examinar a competência da lógica tradicional como um órgão da investigação dos problemas atuais de sentido comum e da ciência." (Dewey, 1960, p. 80).

A produção teórica desse autor constitui o referencial teórico basilar para a pesquisa dos conceitos, princípios e categorias que se busca apreender com o objetivo de responder as questões mencionadas. São feitas incursões nas obras de seus comentadores e críticos, especialmente no que se refere à dimensão conceitual.

Em termos de metodologia, optou-se por uma pesquisa de caráter dissertativo e bibliográfico de base, que se ocupa em examinar a produção deweyana com o objetivo de compreender suas formulações em relação à concepção de conceito e seus desdobramentos na educação. Os procedimentos adotados para desenvolver a pesquisa foram:

a) Percorrer sistematicamente as obras do autor analisando e mapeando conceitos e categorias que serviram de base para a formação da concepção de conceito (autores com os quais dialoga tanto para fundamentar suas idéias, como para criticar; proposições formuladas, relações estabelecidas entre os conceitos principais: articulações, encadeamentos, recorrências, correlações, definições adotadas, originalidade, dentre outros).

b) Evidenciar os nexos da concepção de conceito na filosofia e na educação de Dewey, considerando-os a partir de seu contexto histórico, das relações que estabelece no plano interno de sua obra e no diálogo com seus interlocutores. 
Nossa tese procura mostrar que conceitos, no pensamento deste autor, são instrumentos que o pensamento reflexivo utiliza no processo da investigação, para transformar uma situação problemática, inicialmente confusa, indeterminada, em uma situação resolvida, harmoniosa, como forma de garantir a permanente necessidade de adaptação do indivíduo ao meio, garantindo assim a sua sobrevivência.

Em outras palavras, conceitos são instrumentos de significação ou instrumentos para estabelecer relações, que têm a função de guiar a experiência inteligente do ser humano. São instrumentos sociais de comunicação dessa experiência através da linguagem e instrumentos que corroboram no processo investigativo. A aquisição destes instrumentos deve ser estimulada pela educação.

O primeiro capítulo visa abordar o nascimento do movimento filosófico do Pragmatismo norte-americano, destacando as contribuições de seus fundadores; situar brevemente o contexto histórico norte-americano a partir do qual o autor viveu; apresentar sua biografia destacando as influências recebidas e sua produção teórica.

O segundo capítulo aprofunda a concepção de conceito, o inter-relacionando com outros conceitos e relações centrais na obra do autor: experiência, natureza, continuidade, hábitos, experimentalismo, conduta, dentre outros.

O terceiro capítulo complementa e amplia o anterior, na análise da concepção de conceito e sua função social, a partir do estudo do pensamento reflexivo ou da lógica como teoria da investigação. Sob esta ótica, são analisadas as concepções de linguagem, comunicação e democracia.

O quarto capítulo discute as relações entre conceito e educação. São abordados os conceitos que compõem o quadro da Filosofia da Educação deweyana. 


\section{CAPÍTULO I}

\section{O PRAGMATISMO AMERICANO}

\subsection{Os Fundadores do Pragmatismo}

Os fundadores do movimento filosófico norte americano chamado Pragmatismo são C.S. Peirce ${ }^{2}$, W. James, J. Dewey e H. Mead, cada um com sua contribuição distinta e original para o lançamento das bases do sistema, constituindo-se como uma corrente de pensamento heterogênea. (cf. Schneider, 1950, p. 501)

O termo pragmatismo tem origem grega - pragmata - e significa ação, ato, afazeres. Originalmente o termo foi empregado por Peirce (1993) no artigo "Como tornar claras nossas idéias", publicado em 1878. Peirce empregou o termo Pragmatismo no sentido expressado por $\mathrm{Kant}^{3}$, ou seja, refere-se ao termo pragmatisch que designa estar em relação com algum objetivo humano. Peirce entendeu como sendo a maneira como o conhecimento (saber racional) está relacionado com a ação humana ou conduta (finalidade racional). Foi William James quem popularizou o Pragmatismo quando tentou expor a doutrina de Peirce no famoso discurso para a União Filosófica da Universidade da Califórnia com o título "Concepções filosóficas e resultados práticos" (1897). Entretanto, o próprio Peirce, para fugir da diversidade de sentidos do termo expressos nos periódicos da época e da versão individualista feita por James de seu método lógico, fez questão de retificar o termo para pragmaticismo,

\footnotetext{
${ }^{2}$ Charles Sanders Peirce nasceu em Cambridge, Massachussetts, a 10 de setembro de 1839 e faleceu em Milford, Pennsylvania, a 19 de abril de 1914. Graduou-se em química pela Universidade de Harvard, fez contribuições importantes no campo da Geodésia, Biologia, Psicologia, Matemática, Filosofia e é considerado o fundador da moderna Semiótica. Sua produção em grande parte inédita, só começou a ser conhecida quando a Harvard University Press divulgou seus Collected Papers, obra póstuma, organizada por P.C. Weiss e C. Hartshorne vol. 1 a 6, 1931-35 e por A. Burks - vol. 7 e 8. 1958. Cada volume da obra tem os parágrafos numerados. Como é de costume, a citação desta fonte se dará com a abreviatura da obra - $\mathrm{CP}-$, número do volume e parágrafo.

${ }^{3}$ Diz Peirce: "fui levado ao princípio pragmático pela reflexão sobre a A crítica da razão pura, de Kant. (CP, 5,3) Durante mais de três anos tenho dedicado duas horas diárias ao estudo da $A$ crítica da razão pura, de Kant, até saber quase de memória o livro inteiro e ter examinado com sentido crítico cada uma das suas seções" (CP, 3,4) E acrescenta a amplitude de fontes do Pragmatismo: "toda doutrina que fora totalmente nova, dificilmente deixaria de resultar totalmente falsa; porém, os riachos nos quais nascem o rio do pragmatismo podemos fazê-los remontar quase à antiguidade que queremos." $(\mathrm{CP}, 5,11)$
} 
para designar sua concepção metodológica do pragmatismo, que se ocuparia de estabelecer o estatuto sobre o significado dos conceitos no plano intelectual.

Para além das oscilações por que passa o termo pragmatismo para se fixar como concepção entre os seus primeiros construtores, podemos traçar uma linha comum de reflexão, que consiste em aliar a ciência à filosofia como forma de combater os estilos de pensamento de ordem religiosa ou não, os quais buscam seus fundamentos no absoluto ou num modelo de razão que determina a priori a possibilidade do conhecimento e, neste sentido, instaurar uma nova e distinta forma de pensar. Assim, o pragmatismo primitivo de Peirce, James e Dewey, conforme a análise de Cometti, tem duas características significativas: 1) a validade e a definição de um conceito não podem ser dissociadas dos seus efeitos observáveis, enquanto pertencentes à nossa concepção de objeto; 2) não é possível ter de um conceito uma idéia filosoficamente justa, se não o associarmos aos interesses que entram na sua definição." (Cometti, 1995, p.13). Podemos acrescentar uma terceira característica: a concepção social do homem introduzida pela psicologia social de Mead e Dewey, dentre outros, conforme nos relata Schneider: "uma contribuição mais permanente para a análise social foi feita por um grupo de Chicago, formado por Albion Small, John Dewey, James H. Tufts, George H. Mead, W. I. Thomas e Thorstein Veblen.” (Schneider, 1950, p. 376, grifos nossos). Especificamente sobre a contribuição de Dewey para a psicologia social baseada no método genético, Schneider comenta: "Sua principal contribuição à psicologia social foi mostrar a importância dos interesses profissionais e morais na evolução da experiência humana." (Schneider, 1950, p. 377). Aprofundaremos essa análise no estudo que faremos da psicologia de Dewey. Desenvolveremos a seguir a contribuição de Peirce na construção do Pragmatismo: a concepção de conceito e da investigação.

Peirce, no artigo já mencionado "Como tornar claras nossas idéias", introduz a idéia de que o pensamento tem por finalidade única produzir a crença e que esta é base dos nossos atos, ações ou da nossa conduta. ${ }^{4} \mathrm{O}$ homem é considerado por Peirce como um animal de costumes e crença. Todo o processo se inicia por uma excitação, uma condição irritante em nossa experiência ${ }^{5}$ em que a crença é posta em dúvida por não produzir mais os mesmos

\footnotetext{
${ }^{4}$ Um estudo aprofundado destas concepções de Peirce e desenvolvido pelo Prof. Ivo Assad Ibri em seu livro Kósmos Noētós (1992).

${ }^{5}$ Peirce identifica a experiência com o curso da vida, do qual vertem as idéias e na qual as idéias são precipitadas e filtradas, eliminadas de forma a eliminar o que é falso e dar vigor ao que é verdadeiro. (Cf. CP, 5, 50) E Continua na próxima página.
} 
efeitos: a dúvida que se origina pela surpresa, é geralmente provocada pelo exterior e tem o poder de paralisar a ação. Tal processo, de dissipar a dúvida e estabelecer uma nova crença, Peirce chama de investigação, que significa pensamento em ação buscando ajustar a crença à realidade. O conflito gerado pela dúvida viva e autêntica em nossa experiência leva ao encontro da verdade. A crença elimina a dúvida, nos faz conscientes e estabelece um hábito que regula a ação. Portanto, a crença se fixa no processo da pesquisa que resulta da excitação produzida pela dúvida. Ele extrai a concepção de crença de Bain, que a toma como "hábito de ação" e, para este, os hábitos "são regras da ação" (cf. CP, 4,53) Peirce estabelece uma identidade entre pensamento como crença e produção/instauração de hábito, sendo que uma diferença no pensamento significa uma diferença que se pode observar na prática. Diz Peirce: “A função do pensamento é produzir hábitos de ação (...). Para desenvolver seus significados temos simplesmente que determinar que hábito produz, já que o que uma coisa significa é simplesmente o hábito que implica." (CP, 5, 411-412) Desta forma, entende Peirce que um conceito tem efeitos práticos observáveis que completam a própria concepção. Assim, Peirce elaborou o que denomina de "máxima pragmática", como um princípio de caráter empírico e operante para sua doutrina, a crença que constitui o Pragmatismo:

A fim de determinar o significado de uma concepção intelectual, dever-se-ia considerar quais conseqüências práticas poderiam concebivelmente resultar, necessariamente, da verdade de uma concepção; e a soma destas conseqüências constituirá todo o significado da concepção. (Peirce, 2003, p. 195)

As conseqüências práticas, no contínuo da experiência, são uma fase do pensamento em que a ação não ocorre fortuitamente, mas de forma intencionada, traduzindo o significado ou propósito do conceito. Assim, a ação é controlada pela significação. O pensamento permeia a ação através da significação. Continua a atividade do pensamento na concepção, enquanto soma das conseqüências. A racionalidade se realiza na medida em que se refere a um futuro, quer na ação ou conduta, quer em outro pensamento.

Quando a experiência evidencia que a concepção subjacente à ação está equivocada o hábito adquirido é rompido, desde que o caráter mental da consciência tenha a plasticidade necessária para crescer. A experiência tem um fator corretivo e alimentador do nosso 
intelecto. Quando erramos, procede à correção, buscando novo hábito mais adequado à continuidade da existência. Diz Peirce:

Esta tendência ao erro, quando você a coloca sob o microscópio da reflexão, parece consistir nas variações fortuitas de nossa ação no tempo. Mas escapa à nossa atenção, que em tal variação fortuita, nosso intelecto é alimentado e cresce. Pois sem esta variação fortuita, a aquisição de hábitos seria impossível e o intelecto consiste na plasticidade do hábito. $(\mathrm{CP}, 6,86)$

Através da aprendizagem ${ }^{6}$, da correção, da síntese, da ampliação e do aperfeiçoamento dos conceitos evoluímos ou crescemos. Assim, Peirce desenvolve a idéia que o método científico se justifica em função do fato de se mostrar submisso ao real. Diz ele que este é um método "em que nossas crenças são determinadas não por algo humano, mas por alguma permanência exterior - por algo sobre o que não age o pensamento.” (CP, 5, 384) Esta formulação de Peirce associando crença à regra de ação lhe permite opor-se ao cartesianismo fundado no paradigma da representação. Para Peirce, a investigação começa com uma dúvida autêntica e real por um problema, que nasce em alguma situação efetiva, e que põe em confusão alguma crença. A máxima cartesiana da dúvida completa, que tem dominado a Filosofia, é um passo preliminar inútil, um faz de conta, porque não tem uma razão positiva, não está situada na experiência. (cf. CP, 5, 265/498; 6, 498). Assim, para Descartes o conhecimento consiste apenas em ter idéias claras pelo método da dúvida, que legitimam as conclusões obtidas pelo espírito atento, prescindindo do teste empírico para validá-las. Clareza de idéias, numa perspectiva individualista, difere radicalmente de validade das idéias determinadas pelas conseqüências práticas para o processo de investigação, o que significa dizer que as idéias acarretam uma diferença objetiva de conduta. O paradigma cartesiano corresponde a uma concepção essencialista do conhecimento, tem como pressuposto que o conceito de um objeto corresponde a sua essência, ou seja, está nele inscrita desde sempre. A atividade do intelecto é de apreender esta essência.

No artigo "A fixação da crença”, Peirce (1993) desenvolveu melhor os métodos de trabalhar com a dúvida. Os quatro métodos de resolver a dúvida e fixar a crença são:

\footnotetext{
${ }^{6}$ Peirce argumenta que o princípio evolucionista do contínuo crescimento implica uma regra para a razão: “A primeira e, em um sentido, a única regra da razão, é aquela de que a fim de aprender, você deve desejar aprender, e com tal desejo não se satisfazer com o que você já se inclina a pensar, seguindo-se um corolário que é digno de ser inscrito em todos os muros da cidade da Filosofia: Nunca bloqueie o caminho da investigação." (CP, 1,35)
} 
O primeiro é o método da tenacidade. Tem como característica o apego emocional às crenças tradicionais. É fixado pela lei do exercício e efeito. O seu ponto fraco é que o impulso social originado no contato com outra crença, também legítima, abala a confiança.

O segundo é o método da autoridade e compulsão externa. Visa fixar a crença numa comunidade. Vigora em sociedades conservadoras e sistemas autoritários. Seu ponto fraco é incapacidade de uma instituição regular todos os assuntos da vida comunitária.

O terceiro é o método a priori. Por este método a crença é fixada pela razão de cada indivíduo, não aceitando imposição ou adesão a crenças externas. Seu ponto fraco é estar à mercê do gosto, da espontaneidade dos instintos e acaba servindo à moda. É individualista e arbitrário.

O quarto é o método da investigação experimental ou científica: exige disposição emocional e intelectual para investigar a dúvida e chegar a conclusões que sejam aceitas e provadas publicamente pela comunidade de investigadores. Por isso, este método é considerado superior intelectualmente e moralmente, em relação aos demais.

Sobre este método como promotor da comunidade de crenças e determinação da verdade, Peirce comenta:

O mesmo ocorre com toda investigação científica. As distintas mentes podem pôr-se a andar, desde os pontos de vista mais antagônicos, porém, conforme avança a investigação, uma força alheia a eles os conduz a uma mesma e mesma conclusão. Esta atividade do pensamento que nos leva não a onde queremos, senão a uma meta preestabelecida, é algo, assim, como a ação do destino. Não há modificações do ponto de vista adotado, nem eleição de outros fatos para seu estudo, nem sequer uma tendência natural da mente, capazes de fazer a um homem se iludir a opinião predestinada. Esta grande esperança se encontra encarnada na concepção de verdade e de realidade. A opinião que definitivamente haverá de ser aceita por todos quantos investigam é o que chamamos verdade e o objeto representado nesta opinião é o real. Assim é como eu explicaria a realidade. (CP, 5, 407, 408)

O reconhecimento de Peirce, de que o método de investigação da ciência é capaz de chegar a conhecimentos verdadeiros, é acompanhado do reconhecimento da precariedade destas descobertas e da necessidade de retificação e ampliação. Para Peirce, a verdade é um acordo a que eventualmente chega a comunidade científica, sendo um empreendimento cooperativo, social e público já que uma crença tem sempre um elemento de erro, que é estímulo à investigação, à contínua busca. Se a verdade se encontra no final do processo de investigação, esse processo por sua vez, é infinito e é levado adiante pelos investigadores que trabalham juntos numa comunidade. Os consensos são provisórios. A comunidade de 
investigadores trabalha com um método de investigação autocorretivo e a objetividade se encontra na atividade deliberadora da comunidade como uma totalidade. Mas essa prática de comunidade de investigação não é só meio de chegar à objetividade, mas também tem uma dimensão ética: desenvolve hábitos e atitudes como o compromisso com a autocorreção e autocontrole, disponibilidade para receber novas idéias, seriedade, perseverança, honestidade e cooperação. Portanto, para Peirce, a comunidade de investigação tem um sentido epistemológico e ético já que a investigação científica é um processo comunitário cujo resultado é por ela garantido. Peirce desenvolve assim a teoria falibilista do conhecimento.

A doutrina do Falibilismo de Peirce decorre da maneira como ele compreende o Evolucionismo. Para Peirce, encontramos na natureza fenômenos que seguem alguma Lei, provisoriamente, e fenômenos que ocorrem ao acaso. Historicamente, o acaso foi reconhecido por filósofos como Aristóteles, Lucrécio e Demócrito, entre outros. Entretanto, na ciência moderna, este princípio ficou obscurecido pela crença num universo determinado pela Lei. Trata-se, por exemplo, do mundo mecanicista de Descartes, da teoria de Einstein, entre outros. (CP, 1, 403) Os defensores desta regularidade exata, como uma fé determinista, a justificam recorrendo ao argumento de ser um pressuposto ou postulado (incognoscível) da ciência, ou a razões a priori. $(\mathrm{CP}, 6,48)$ Ambos os casos barram a investigação e são intrinsecamente contraditórios.

Peirce, por sua vez, pautado pela experiência de laboratório, encontra na determinação arbitrária do acaso a explicação para as observações que evidenciam afastamento da lei $(\mathrm{CP}, 6,48)$. Portanto, pelas observações rigorosas descobre-se a imprecisão do mundo. A acaso é responsável também pelo crescimento da complexidade e diversidade das coisas no universo. (CP, 6, 57-58) Peirce constrói, a partir daí, sua hipótese de que as leis da natureza, derivadas do acaso, são evolucionárias e, portanto, ainda em evolução. Mais ainda, o acaso adquire o estatuto de um princípio ou lei que pode evoluir e se desenvolver por si mesmo. Peirce infere, ainda, uma tendência da lei do acaso: "Evidentemente, ela deve ser uma tendência à generalização - uma tendência generalizadora [...] Contudo, a tendência generalizadora é a grande lei da mente, a lei da associação, a lei da aquisição de hábitos [...] Assim, sou levado à hipótese de que as leis do universo têm sido formadas sob uma tendência universal de todas as coisas à generalidade e à aquisição de hábitos.” (CP, 7, 512-514) Porém, diz Peirce, como toda lei resulta da evolução ela não é absoluta. Os fenômenos ou fatos envolvem afastamento da lei. (CP, 6, 101) Assim, toda descrição de leis deve obedecer ao âmbito de sua operação, em torno da qual os fatos adquirem freqüência regulares, mas não 
absolutas. Desta forma, Peirce fundamenta a doutrina do Falibilismo: "Todo raciocínio positivo é da natureza de julgar a proporção de alguma coisa no todo e de uma coleção pela proporção encontrada em uma amostra. Assim, há três coisas que nunca podemos esperar obter pelo raciocínio, a saber, a certeza absoluta, exatidão absoluta, universalidade absoluta.” (CP, 1,141) Afirmar que o conhecimento não é absoluto é reconhecer a sua provisoriedade dentro do processo de evolução contínua. O Falibilismo, diz Peirce, "é a doutrina de que nosso conhecimento nunca é absoluto, mas é como se sempre flutuasse em um continuum de incerteza e indeterminação." (CP, 1, 171)

Essa nova visão de pensamento e conhecimento do mundo é explicada em termos pragmáticos e empíricos. O conceito clássico de verdade que a toma como representação mental - idéia, imagem, cópia - das coisas é questionado em suas bases. Por sua vez, o pensamento, também, não é uma propriedade do intelecto ou razão, ou algo que ocorre na mente dos indivíduos separado da natureza. James, por exemplo, coloca a verdade como uma construção processual feita pelo sujeito através da análise das conseqüências práticas em sua experiência, rompendo com as concepções de verdade do racionalismo (verdade como reflexo do objeto que se impõe ao sujeito). James argumenta da seguinte maneira: A verdade de uma idéia não é uma propriedade estagnada inerente a ela. A verdade acontece a uma idéia. A idéia se torna verdadeira, é feita verdadeira pelos eventos. Sua verdade é de fato um evento, um processo, o processo notadamente de se verificar a si mesmo, sua verificação. "Sua validade é o processo de sua validação." (James, 1974, p. 41, itálicos do autor) A verdade é uma idéia útil que se torna verdadeira pelos acontecimentos. Para completar o raciocínio: "Verdadeira é o nome para qualquer idéia que inicie o processo de verificação, útil é o nome para sua função completada na experiência.” (James, 1967, p. 118). Por sua vez, a experiência está na mutação, assim como a verdade. Decorre daí a dependência da verdade da dimensão psicológica (do sujeito) que faz a ligação, estabelece os elos entre verdades novas e antigas. Explica James que o processo da verdade tem um efeito similar ao de bola de neve: "No reino dos processos-verdade, os fatos vêm independentemente e determinam nossas crenças temporariamente. Essas crenças, porém, fazem-nos agir, e tão rápido quanto assim procedem, trazem à vista, ou à existência, novos fatos que tornam a determinar consequentemente as crenças." (James, 1974, p. 33) Neste sentido, a verdade depende da experiência individual e tem imenso valor prático dado na própria experiência. James usa a metáfora do "cozinhar" para expressar a importância da experiência na validação da verdade: "A experiência, como sabemos, tem meios de cozinhar, e de fazer-nos corrigir nossas fórmulas presentes." (James, 
1974, p. 32, itálicos do autor) Ao recusar a verdade como correspondência, James associa a idéia de verdade ao que é útil e que se testa nos interesses que satisfaz. Contrasta com o racionalismo que sustenta a teoria da cópia, na qual as idéias são ineficazes e impotentes, um espelho da realidade completamente sem a realidade. Contrasta, também, a noção de realidade: para o pragmatismo de James ela é um contínuo processo de fazer-se, enquanto que no racionalismo é uma eterna edição acabada e completa em si mesma. James promove assim deslocamento significativos do conceito de verdade: do essencialismo para o funcionalismo dos conceitos; da verdade absoluta para a verdade prática, útil, funcional, ou meias-verdades temporais; do objeto para o sujeito; da razão intelectual para a reflexão prática. Esta postura marca o nominalismo de James, em relação ao realismo de Peirce. Analisaremos a seguir o pragmatismo de Dewey.

\subsection{O PRAGMATISMO DE DEWEY}

\subsubsection{John Dewey - Vida e obras}

Em um texto autobiográfico intitulado From absolutism to experimentalism (1930) Dewey comenta a dificuldade de se autodefinir como filósofo, a partir de sua mudança de posição em relação ao idealismo alemão, porque ainda se sente em processo de mudança, instável, recolhendo diversas influências, algumas até incompatíveis, lutando para assimilar algo de cada uma, esforçando-se para dar continuidade lógica consistente ao novo a partir do que já aprendeu. Na verdade, estava sendo fiel à missão que considerava apropriada para o filósofo: exprimir os profundos conflitos e as infindas incertezas da civilização de que participa (cf. Dewey, 1968, p. 7).

Ainda neste relato autobiográfico, ele enfatiza que as pessoas e as situações exerceram mais influência sobre sua vida do que os livros. Estes contribuíram com um aprendizado um tanto técnico, enquanto que as pessoas e situações o forçaram a pensar as experiências em que se encontrava confuso. Declara seu gosto pelo pensar, embora pareça uma "reação de defesa" diante das inconveniências que foi obrigado a enfrentar na sua trajetória de vida, mas que teve uma vantagem que foi a de não o induzir a uma imunidade do pensamento em relação à experiência.

Estas declarações do autor indicam a importância de localizá-lo no tempo para poder entender seu pensamento e sua obra. Por isso, num primeiro momento, voltaremos nosso 
olhar para o contexto histórico em que ele se situa, pensa e produz e, em seguida, iremos percorrer sua própria trajetória de vida.

Sem a pretensão de fazer uma análise histórica exaustiva, resgataremos algumas informações de vital importância para compreender o movimento histórico em que Dewey nasce e cresce $^{7}$ : a) passada a Guerra Civil Americana (1861 a 1865), o país entra num período de consolidação nacional nos níveis econômico, social, político e cultural. Passa a preponderar a era da industrialização e do comércio. Desta forma, há uma nova divisão do trabalho com a mudança da estrutura social agrária e rural para a industrial e comercial urbana; b) secularização e universalização do ensino público, com aumento significativo do número de alunos, exigindo revisão nos programas de estudos e orientação vocacional, orientados mais por temas laicos (científicos, tecnológicos e filosóficos), corroborado pelo aumento de intelectuais formados no exterior; c) separação entre Estado e Igreja; d) ascensão do nacionalismo emergente pautado pelo liberalismo, que valoriza a educação como fator de desenvolvimento econômico, social, político e cultural; e) emergência da moderna ciência em contraponto aos dogmas religiosos; f) institucionalização da universidade norte-americana organizada sob a forma privada laica e privada religiosa. As universidades são subsidiadas por recursos financeiros vindos de investimentos de capitalistas industriais e comerciantes americanos na educação. Nesse contexto, por exemplo, se dá a abertura da Universidade que leva o nome de Johns Hopkins (1876), um comerciante rico de Baltimore, e da Universidade de Chicago (1890), subsidiada por John D. Rockfeller, um magnata do petróleo. A orientação da Universidade de Johns Hopkins estava marcada pela valorização de pesquisas originais e pelos trabalhos realizados em seminários e com ênfase para as questões de ciência, tecnologia e filosofia. Dewey nos dá um depoimento significativo sobre a importância dessa universidade: "É lugar comum na história educacional, que a abertura da Universidade de Johns Hopkins marcou uma nova era na educação superior nos Estados Unidos." (Dewey, 1930, p. 18) A abertura dessa universidade serviu de referência para a expansão de graduações nas universidades, provocando uma "reviravolta na cultura americana." (cf. Dewey, 1930. p. 18) Seguindo essa tendência, as universidades estatais também passaram a incluir temas seculares e utilitários. Os benefícios financeiros advindos dos investimentos

\footnotetext{
${ }^{7}$ Tomaremos como referências os estudos dos seguintes autores: SCHNEIDER, Herbert W. 1950. História de la filosofia norteamericana; BUTTS, Freeman and CREMIN, Lawrence A. 1959. A history of education in American culture; DEWEY, J.1930. From absolutism to experimentalism; MILLS, Wright C. 1966. Sociology and pragmatism.
} 
filantrópicos nas escolas e universidades confessionais (fundamentos religiosos), ou não, exigiram uma mudança na administração e no próprio currículo dessas instituições, tarefa que passou a cargo dos homens de negócio e menos influenciados pelo setor clerical.

Em termos culturais, temos o predomínio de três estilos de pensamento, como podemos conferir na classificação elaborada por Butts e Cremin:

Três principais orientações intelectuais podem ser identificadas operando na América no período em consideração [pós Guerra Civil]. Cada uma delas desenvolveu um conceito distinto de homem, de suas características essenciais, de seus processos de pensamento e aprendizagem, e de uma educação apropriada ao homem tal como foi concebido. Uma vê o homem como um reflexo de Deus. Em suas várias formas o teísmo fundamentalista cristão, a teologia liberal, a filosofia do idealismo e o novo humanismo dualista recorreu à autoridade do espírito. Eles vêem o homem essencialmente como um ser espiritual. O segundo ponto de vista vê o homem como um reflexo do mundo natural. Nas formas de uma filosofia empírica da mente, uma filosofia realista do conhecimento e uma psicologia objetiva da aprendizagem (conhecida posteriormente por conexionismo) recorreu à autoridade das ciências naturais. Elas vêem o homem essencialmente como um complexo organismo biológico. $\mathrm{O}$ terceiro ponto de vista vê o homem como um reflexo da sociedade humana. Aqui uma concepção social da mente e a nova e distinta filosofia americana do pragmatismo e experimentalismo recorreram não apenas à autoridade das ciências naturais, mas também às ciências sociais. Elas vêem o homem primordialmente como um ser social e cultural. (BUTTS E CREMIN, 1959, p. 325)

Diante desta classificação, que mostra as principais tendências intelectuais da época, evitaremos cair num certo imediatismo simplista de enquadrar o pensamento deweyano nesta ou naquela tendência, uma vez que nos parece mais prudente entender como Dewey se posicionou diante delas. Desta forma e em continuidade ao que foi sugerido anteriormente, abordaremos a seguir a biografia do autor, as pessoas, situações e livros que deram o tom para sua produção na área de filosofia e educação.

John Dewey ${ }^{8}$ nasceu aos 20 de outubro de 1859, na pequena cidade de Vermont, numa região agrícola denominada Burlington, na Nova Inglaterra, situada a extremo Leste dos Estados Unidos. Terceiro filho de Arquibald Dewey, comerciante bem sucedido que se casou com quase cinqüenta anos com Lucina Rich, vinte anos mais jovem, de família conceituada política e culturalmente.

\footnotetext{
${ }^{8}$ Nossas principais fontes de referências sobre esses dados biográficos são: DEWEY, (1930), Amaral (1990), Pitombo (1974) e Schneider (1950).
} 
Sua infância foi marcada pelo espírito familiar comunitário no qual as crianças desenvolvem pequenas tarefas como forma de despertar um espírito de responsabilidade. (cf. Amaral, 1990, p. 32) Sua educação básica e universitária deixou a marca de uma forte divisão: por um lado, a vida escolar marcada pelo fastio e pesadelo da "escola de memorização", dos livros escolares e aulas que não despertavam interesse nos alunos; por outro lado, o interesse pelas demais leituras e um rico e amplo aprendizado fora da escola.

Dewey inicia sua formação superior na Universidade de Vermont, Nova Inglaterra, bacharelando-se no ginásio em 1874, com 15 anos. No terceiro ano, teve seu primeiro contato com estudos que abririam os horizontes da Filosofia, através do Curso de Fisiologia, um estudo do darwinismo a partir do livro de T.H. Huxley, Lessons in Elementary Physiology (1866). Ele relata que este estudo do organismo humano lhe deixou um senso de unidade interdependente e inter-relacionada que lhe serviria como modelo de visão de mundo e da vida. Este estudo foi tão estimulante, que Dewey declara ser o responsável por despertar seu interesse filosófico. Constituirá também uma referência de base para desenvolver sua filosofia alicerçada no princípio de continuidade e de inter-relação de todos os seres no mundo. $\mathrm{O}$ modelo biológico darwinista de adaptação do indivíduo ao meio será uma marca constante na elaboração dos conceitos de sua filosofia. (cf. Dewey, 1930, p.13)

Outro estudo que o influenciou foi a síntese de Harriet Martineau do Curso de Filosofia Positiva, de Augusto Comte. Dewey chegou a declarar que não lembrava se a lei dos três estágios influenciou seu pensamento, mas ficou impressionado com a crítica comteana ao caráter desorganizado da cultura ocidental, devido ao individualismo desintegrado e à necessidade da função social da ciência, como um método regulador da vida organizada. Esta visão crítica combinaria com a solução hegeliana da integração que ainda estava por estudar. (cf. Dewey, 1930, p.20)

A Universidade de Vermont se orgulhava do pioneirismo em filosofia e ao mesmo tempo pelo ambiente de teologia liberal de cunho congregacionalista. O curso de filosofia era ministrado por professores homens, clérigos, uma vez que a orientação religiosa / teológica pesava sobre o ensino de filosofia. A controvérsia reinante no curso era entre as seguintes tendências: por um lado, o grupo que iniciou os estudos sobre os pensadores alemães (Kant, Schelling e Hegel) na América, especialmente com o Prof. Marsh; por outro lado, havia os estudiosos da Escola Escocesa, que defendia a crença intuitiva em Deus. Esta tendência acabou se tornando dominante com o controle maior sobre o ensino de filosofia feito pela direção da universidade. Deste grupo, destaca-se o Prof. H.A.P. Torrey, com genuíno 
interesse na filosofia, baseando também seu ensino na filosofia escocesa. Dewey aproveitou o potencial e a genialidade desse professor, revelado em aulas públicas e especialmente em aulas particulares. Ele reconhece a dupla dívida que tem com este mestre: uma, a sua decisão definitiva de ocupar-se com o estudo da filosofia e, a outra, a orientação particular na leitura dos clássicos da história da filosofia, além de lhe ter ensinado a ler filosofia alemã, especialmente o idealismo kantiano.

A filosofia escocesa se deu bem nessa universidade devido a sua aliança com a religião, especialmente com a causa da "intuição". O debate teológico que se travava nesta universidade era entre o intuicionismo e o sensacionalismo empirista, que pretendiam dar explicações satisfatórias para a realidade de todos os "objetos do alto". Para Dewey, tal debate direcionava de forma errada a abordagem dos problemas filosóficos, o que lhe despertou um certo ceticismo sobre essas questões e, ao mesmo tempo, ajudou a gerar um senso de valor ao estudo da história da filosofia.

Ele foi criado em um ambiente evangélico convencional extremamente liberal, (cf. Dewey, 1930, p.15) no qual a comunidade exercia a liberdade na formulação de sua fé numa prática democrática, independente, com igualdade e solidariedade entre os seus membros (cf. Schneider, 1950, p. 4). Esta experiência religiosa numa comunidade organizada de forma democrática contribuiu para o crescimento de sua fé na democracia como uma forma de associação humana mais repleta moral e espiritualmente, e será outro referencial sólido no desenvolvimento de suas idéias.

A filosofia por sua vez não foi a causa ou mesmo o motivo central que o influenciou a experimentar uma crise religiosa pessoal, uma crise de ceticismo. A luta entre aceitar aquela fé e descartar a crença religiosa tradicional e institucional advém de suas experiências pessoais, e não propriamente da filosofia. Suas experiências estavam marcadas pelo conflito entre as crenças religiosas tradicionais e as opiniões que teve que acolher com honestidade. Seu sentimento era que uma experiência genuinamente religiosa poderia ser adaptada a qualquer crença que alguém intelectualmente escolhesse seguir. A experiência religiosa é a que possibilita um senso de comunidade e ligação do indivíduo como membro de um todo infinito. (cf. Dewey, 2002, p. 331) Sua simpatia é pela capacidade pessoal de mudar de atitudes, mais do que por uma religião. Declara: "Eu tenho bastante fé na profundidade das tendências religiosas dos homens de acreditar que eles irão adaptar a si mesmos a qualquer mudança intelectual exigida, e é inútil (e é como ser desonesto) prever prematuramente com exatidão qual forma irá tomar o interesse religioso, como conseqüência final da grande 
transformação intelectual que está acontecendo." (Dewey, 1930, p.20) Às críticas que o consideram demasiado reticente na questão religiosa, ele responde dizendo que o grande problema nesse campo é que com freqüência se sobrepõem os interesses partidários de uma religião particular acima dos interesses genuínos da experiência religiosa. "Assim, outros deuses foram fixados antes do Deus único.” (Dewey, 2002, p. 331) Para Dewey os interesses sociais e os problemas de seu primeiro período, presentes principalmente nas questões religiosas, constituíam um apelo intelectual distinto e forneciam a substância de suas preocupações intelectuais a serem desenvolvidas pela filosofia. (cf. Dewey, 1930, p.20)

Após sua formatura na Universidade de Vermont, Dewey leciona por dois anos em South Oil City - Pennsylvania. Retorna a Burlington, onde leciona outros dois anos em escola primária. Continua suas conversas com o Prof. Torrey, mas já rejeita o intuicionismo escocês bem como o empirismo, tomando por base os postulados de Kant na defesa da necessidade do espírito para conhecer os fenômenos.

Foi encorajado por Dr. W. T. Harris a continuar os estudos na área de Filosofia a partir de um artigo escrito para o Journal of Speculative Philosophy. Este era o único periódico de filosofia no país, sob responsabilidade de um grupo de leigos dedicado à filosofia sem razões teológicas. $\mathrm{O}$ artigo estava ainda em linguagem intuicionista, muito esquemático e formal, e não correspondia ainda aos interesses mais profundos de Dewey, que eram os incidentes e pressões da experiência pessoal, a ênfase sobre a vida concreta, empírica e prática que apareceriam em seus escritos posteriores. O ensaio que Dewey apresentou a Harris é publicado nesse periódico (04.1882) e lhe abre caminhos para o doutorado. Esta fase de Vermont é considerada como a fase do primeiro Dewey, marcada por duas tendências: uma retrata sua preocupação em reconciliar religião com ciência e, outra, por seus interesses pelos problemas de epistemologia na busca pela natureza da mente, verdade e conhecimento. (cf. White, 1977, p. 6)

Nesta ocasião, Dewey decidiu dedicar sua vida ao estudo da filosofia e ingressa no programa de doutorado da Universidade de Johns Hopkins (Baltimore, Maryland) em 1882. Esta universidade marcou uma nova época dos estudos superiores em educação e é responsável pela mudança da cultura Americana, operada logo após a guerra civil, que inaugurou a era da industrialização e comércio. A filosofia passava por um movimento de renovação vital e construtivo. Segundo M. G. White, o departamento de filosofia dessa universidade abrigava pensadores de tendências opostas ao realismo escocês. Os principais membros do departamento de filosofia daquele período foram Charles Peirce, G. S. Morris e 
G. Stanley Hall. (cf. White, 1977, p. 6) O presidente desta universidade, Daniel Coit Gilman, tido como um anti-metafísico, deu forte ênfase ao valor dos trabalhos em seminários, prática esta que marcará a formação de Dewey. As influências mais marcantes foram de G. S. Morris, como veremos com mais detalhes a seguir e, também, de S. Hall. Este era discípulo de Wundt e tinha desprezo pelo método hegeliano. Suas preleções levaram Dewey a estudar psicologia experimental e exerceram influência sobre a obra Psycology, publicada em 1887. Esta obra traz também as influências que herdará de Morris que, em contraposição a S. Hall, é um adepto do pensamento de Hegel. Cabe ainda perguntar: qual foi a influência de Peirce sobre Dewey neste período em Baltimore? Dewey considerava seu professor inteiramente devotado à lógica formal, o que não o atraía; pelo contrário, a sua adesão a Hegel o levou a se contrapor a este sistema lógico. Assim, Peirce não o influenciou neste período, mesmo tendo já esboçado sua filosofia através dos artigos já publicados: "Como tornar claras nossas idéias" e "A fixação da crença".

A influência mais significativa deste período deve-se às preleções públicas e seminários organizados pelo Prof. G. S. Morris, professor leigo de filosofia, de personalidade marcante pelo entusiasmo e devoção intelectual e adepto do hegelianismo. Segundo seu aluno, Morris fazia uma leitura de Kant através de Hegel, e não o inverso, tomando uma atitude crítica em relação a Kant, expressada pelo próprio Hegel. Reverenciava Aristóteles e não tinha dificuldade de o unir com o pensamento de Hegel. O professor, segundo Dewey, defendia que a única questão filosófica era o significado da existência. M. G. White, no estudo da influência deste professor de Dewey, expõe que Morris era um crítico do empirismo inglês e ardente adepto do idealismo alemão. Em seu livro British Thought and Thinkers os empiristas são acusados principalmente de subordinar a teoria à prática e de elevar indevidamente o método da ciência física. Neste livro, especialmente no capítulo sobre Locke, Morris critica a identificação da psicologia empirista com a filosofia e desfere seu ataque aos que dispensam a teoria das idéias inatas. Mesmo sendo crítico à filosofia de Kant, reconhece nela o início do idealismo alemão, que foi coroado com Hegel, o qual concebe a realidade como um sistema conectado. Morris interpretava Hegel no que concerne à consciência da seguinte forma: $\mathrm{O}$ universo é de certa forma construído pelo pensamento, antes que qualquer mente humana começasse a pensar. A consciência empírica ou consciência individual está em orgânica relação com os objetos do conhecimento. A consciência empírica e os objetos estão inseridos na consciência universal, constituindo um todo vivo, com um espírito comum. Os significados estão na mente universal para serem decifrados pelo indivíduo. 
Morris também destaca que a virtude de Kant foi reconhecer que como as formas e funções da mente não eram sensações elas pertenciam a uma realidade vital e absoluta. As demonstrações kantianas destas formas na experiência cotidiana mostravam o poder e realidade da "energia da inteligência", ação do espírito, ou uma autoconsciência dinâmica, e não um estado passivo de sentimentos conscientes. Morris estabelece assim as bases para a concepção de mente ativa e será uma das maiores influências em Dewey. Esta discussão forneceu as bases para o ataque de Dewey à teoria expectadora do conhecimento e o problema da relação entre a psicologia e a filosofia. Esta obra de Morris, somada ao livro Kant`s Critique of Pure Reason, contribuíram para o desenvolvimento da doutrina deweyana do instrumentalismo: o ativismo e o anti-dualismo (cf. White, 1977, p. 12 a 27) Dewey herdou também desse mestre outras influências: o seu espírito de ensino, a idéia hegeliana de organicismo, ou seja, da experiência como um todo orgânico, vivo e dinâmico e a sua concepção de lógica, que opõe a lógica real à formal, dando-lhe base para desenvolver uma lógica instrumental, como processo de busca da verdade.

Sobre a influência que Hegel exerceria em seu pensamento, Dewey declarou:

Havia, contudo, também razões subjetivas para o apelo que o pensamento de Hegel fazia em mim. Ele supria a procura por unidade que era, sem dúvida, um anseio emocional intenso ou mesmo uma fome que somente um alimento intelectual poderia satisfazer. É mais do que difícil, é mesmo impossível, recordar aquela primeira disposição, mas o senso de divisão e separação que, suponho, foram-me impostas como conseqüência da herança da cultura da Nova Inglaterra, divisões expressas pelo isolamento do eu em relação ao mundo, da alma em relação ao corpo, da natureza em relação a Deus trazia uma dolorosa sensação de opressão - ou melhor, era uma dilaceração interna. Meus primeiros estudos de filosofia tinham sido uma ginástica intelectual. A síntese hegeliana do sujeito e objeto, matéria e espírito, divino e humano era, contudo, não meramente uma fórmula intelectual; ela proporcionava um alívio imediato, uma libertação. O tratamento de Hegel à cultura humana, às instituições e às artes, envolvia a mesma dissolução da dura e firme parede divisória e teve uma especial atração para mim. (Dewey, 1930, p. 19).

Mesmo reconhecendo que essa influência seria permanente em seu pensamento, ele identifica, que após quinze anos, desde que conhecera o sistema hegeliano, este passaria a ser visto como uma forma, um esquematismo artificial em último grau. Diz Dewey: “Todavia, eu nunca devia pensar em ignorar, muito menos duvidar, o que uma crítica astuta ocasionalmente refere-se como uma recente descoberta, - que aquela familiaridade com Hegel deixou um depósito permanente no meu pensamento. A forma, o esquematismo de seu sistema pareciame agora artificial ao último grau.” (Dewey, 1930, p.21) Continuaria admirando o conteúdo de suas idéias, a extraordinária profundidade e agudez de sua análise com exceção da dialética 
mecânica, a riqueza e grande variedade de insights que não encontrou em nenhum outro filósofo sistemático, excluindo Platão. Platão é o filósofo preferido para sua leitura (cf. Dewey, 1930, p. 21). Explica que sua leitura de Platão se aproxima mais daquela dos céticos e não dos que forçam a uma estrutura doutrinária rigidamente sistematizada. A melhor forma de apresentar o filosofar seria, segundo Dewey, o movimento de volta aos diálogos de Platão, na dramaticidade, inquietude e inquirição cooperativa, em que se tenta um modo de atacar atrás do outro para ver o que pode descobrir (autorizar). Esta volta a Platão, permite perceber que os mais altos vôos da metafísica sempre terminam com uma mudança social e prática, contrastando com um Platão artificial, construído por comentadores sem imaginação, que o trataram como um professor universitário original. (cf. Dewey, 1930, p.20)

Na vida prática, o Prof. Morris, além de lhe confiar o ensino de História da Filosofia, convidou-o para ensinar na Universidade de Michigan, em Ann Arbor, onde permaneceu no período de 1884 a 1894, sendo que num desses anos (1888-89) trabalhou em Minnesota. O ambiente da Universidade de Michigan era conduzido por ideal democrático de liberdade e responsabilidade, imprimido pelo presidente dessa instituição. Por sua vez, o ambiente religioso serviu para reforçar sua fé na democracia.

Dewey conheceu, em Ann Arbor, Alice Chipman, aluna da Universidade, com quem se casou em julho de 1886. Alice foi professora por muitos anos. A personalidade marcante de Alice, livre pensadora, inteligente e sensível, fez com que Dewey pudesse rever a questão religiosa como originária da própria existência natural e, por causa dela, afastou-se do partido republicano, de política conservadora, desgostando seu pai.

O período em Ann Arbor está marcado pela forte influência do idealismo alemão. Neste período, Dewey escreve dois importantes artigos no periódico Mind: "The Psychological Standpoint" e "Psychology as Philosophic Method" (1986) Nestes artigos Dewey desenvolve sua crítica a Kant considerando que a concepção de pensamento deste filósofo é formal e analítica, mas ativa e, por isso, dá um passo importante na transição do pensamento abstrato. Da mesma forma a concepção empobrecida de experiência adquire um novo sentido, na medida em que adquire as qualidades de crescimento, enriquecimento. Entretanto, é Hegel quem avança, ao introduzir a concepção de razão que constitui a experiência, cancelando a separação entre existência subjetiva e objetiva, e explicando-a em termos de sistema, unidade orgânica. Dewey esboça sua teoria do conhecimento segundo M. White: 
Ele precisava somente converter a consciência universal em natureza, o individual em organismo, e o objeto do conhecimento em ambiente. $\mathrm{O}$ resultado, traduzido em termos naturalísticos, é que o organismo e seu ambiente são ambos partes da natureza. Isto segue que tudo o que guarda verdade da natureza em geral, guarda verdade do organismo humano em particular, e que a atividade ou capacidade conhecida como 'conhecimento' aparece no homem em acordo com o princípio da evolução. (White, 1977, p. 46)

Dewey vai revendo aos poucos essa influência através dos estudos sobre ética e psicologia. Em 1887, aparece seu livro Psychology, em seguida Leibniz`s New Essays Concerning the Human Understanding (1988), e outro livro chamado Applied Psychology (1989). Os seus estudos sistemáticos sobre ética foram motivados a partir de sua atuação docente na Universidade de Michigan. Seus dois trabalhos publicados neste período sobre a ética estão fortemente influenciado pelo idealismo: "Ethics and Phisical Science" (1987) e “The Ethics of Democracy” (1888) Dewey defende nestes artigos que o homem está intrinsecamente relacionado com os outros homens, e que a democracia é uma forma de vida em sociedade.

Publicou trabalhos nos quais inicia sua revisão sobre este tema a partir do desenvolvimento da função da inteligência: Outlines of a Critical Theory of Ethics (1891), The Study of Ethics (1894) e The Study of Ethics: a Syllabus (1894) Nestes trabalhos Dewey descarta a idéia de consciência universal, questiona a suposta união da inteligência com o mundo no modelo idealista, e introduz a idéia de que o mundo é constituído por uma lógica e que o conhecimento desta lógica oferece a possibilidade de controle pela inteligência. Assim, a inteligência tem a função social de conduzir as questões sociais e é a base da democracia. A ciência tem função social. Concebe também que o ideal da conduta é a realização da personalidade ou do self e que a vida moral consiste no crescimento da liberdade. Cabe ao indivíduo se adaptar e construir instrumentos para resolver seus problemas. Dewey postula que o critério do valor moral de um ato reside no julgamento dos prováveis resultados do ato, o que somente é possível através do ato e não fora dele, pois isto seria uma mera abstração: "Exatamente no grau em que alguma conseqüência é considerada como provável resultado de um ato, exatamente neste grau ele adquire seu valor moral, pois ele se torna parte do próprio ato. (...) os resultados concebíveis constituem o conteúdo do ato a ser executado. Eles não são meramente relevantes para a moralidade, mas são sua qualidade moral. (Dewey, 1891, p. 9)

Michigan acalentou suas preocupações pedagógicas através da cadeira de Educação, pioneira em seu país, que colocava alunos e mestres em contato com os ginásios oficiais. 
Dewey foi membro do Clube de Professores da Universidade, entidade que tinha por objetivo aproximar escola secundária e universidade.

Ainda em Michigan, os estudos psicológicos, teóricos e experimentais sobre a obra de Stanley Hall ajudam-no a completar seus conhecimentos na relação entre Psicologia e Filosofia.

Dewey simpatiza-se pela psicologia experimental, não associacionista. A sua referência é o livro de psicologia biológica de William James', Principles of Psycology (1890), como uma teoria pragmática do conhecimento, a qual Dewey irá incorporar em seu pensamento. Esta obra que tem influência vital no pensamento deweyano, dando direção e qualidade, "agiu como um fermento na transformação de velhas crenças" e é uma exceção no que concerne às influências exercidas pelos livros em sua vida. (cf. Dewey, 1930, p. 24). Nesta obra, W. James introduz e usa o conceito biológico de psyche, aproveitando os progressos da biologia, e desenvolve a idéia de vida em termos de "vida em ação", contrariamente aos demais estudos de psicologia que adotam a idéia de organismo, mas de forma estrutural e estática. Com James, a conexão da psicologia com a filosofia passa a ter consideração, especialmente pelos fatores biológicos objetivos na concepção de pensamento (discriminação, abstração, concepção, generalização). Dewey manterá viva a relação entre psicologia e filosofia em sua obra para romper com o divórcio entre o pensar filosófico e as questões que se originam na existência:

A mais nova psicologia objetiva fornece o caminho mais fácil, em termos pedagógicos senão em abstrato, para se alcançar uma frutífera concepção de pensamento e do seu trabalho, e para melhorar nossas teorias lógicas precavidos de que pensamento e lógica tem a ver um com o outro. E no presente estado da mente humana, a ligação da filosofia com as questões

\footnotetext{
${ }^{9}$ William JAMES nasceu em Nova York, em 1842 e morreu em New Hempshire em 1910. Filho de rica família norte americana teve a oportunidade de estudar acompanhado de seu irmão Henry, em Londres, Paris, Geneve, Bonn. Estudou artes, química, anatomia e fisiologia. Esteve no Brasil na expedição de Louis Agassiz. Graduou-se em medicina em Harvard, em 1869. Apesar da forte influência religiosa familiar, James entusiasmou-se pelas idéias de livre arbítrio de Mill, Bain, e Spencer. Proclamou: "Meu primeiro ato de livre arbítrio será acreditar no livre arbítrio." Em 1872, foi indicado como professor de Fisiologia em Harvard. Três anos depois, fundou o primeiro laboratório norte americano de experimentos em Fisiologia e Psicologia. Em 1890, publicou, em dois volumes, Principles of psycology. Outra obra importante, retratando suas experiências religiosas, é The varieties of religious experience. Redirecionou suas energias para a filosofia, influenciado pelo seu colega de Harvard, Charles Peirce, fundador do Pragmatismo. Publicou uma coletânea de conferências sobre o pragmatismo de Peirce, intitulado de Pragmatism: a new name for some old way of thinking, em 1907. Outras obras desse período: The meaning of truth, em 1909 ; obra póstuma: Essay in radical empiricism; publicada após sua morte temos: Some principles of philosophy. (Cf. James, 1952)
} 
significantes da experiência atual é facilitada pela constante interação com os métodos e conclusões da psicologia. (Dewey, 1930, p. 25)

Outro aspecto importante da psicologia de James a partir da biologia objetiva é que leva a perceber a importância de categorias sociais distintas, especialmente da comunicação e participação.

Entretanto, Dewey sinaliza distanciamento de James em artigo publicado em 1893, no Philosophical Review, com o título "Self Realization as the Moral Ideal”. Neste artigo ele critica a idéia de Self como um esquema ou essência fixa, transcendental e individual e o explica em termos de uma realização deste esquema. O Self é sempre uma atividade específica e concreta e se identifica com a realização tornada possível pela atividade. Desta forma, Dewey recusa a idéia de uma mente universal e ego individual dando a este a compreensão de comportamento individual. A negação da possibilidade de ego universal, metafísico significa uma crítica a W. James e uma diferença importante na construção da psicologia social deweyana.

No ano de 1894, Dewey foi para a recém inaugurada Universidade de Chicago, a convite de seu amigo, o Prof. J. H. Tufts, onde permaneceu até 1904. Nesse período conviveu com dois grandes mestres que vieram substituir Tufts. Dewey partilha do seu fundamento instrumentalista com A. H. Lloyd - que concebe a idéia como plano de ação, a consciência como ato de estabelecer um plano - e da crítica ao abstracionismo.

De George H. Mead ${ }^{\mathbf{1 0}}$, com quem já convivia desde Michigan (1891), adotou as idéias a respeito da Psicologia Social. Declara em seu último livro: "Também devo a George H. Mead muito mais de que se infere pelo texto.” (Dewey, 1950, p. 5)

Nesse período de Chicago, fundou a Escola-Laboratório da Universidade (1896), uma escola experimental, conhecida também como Escola Dewey. Nessa escola Dewey pôde experimentar e comprovar suas idéias pedagógicas. A escola se tornou estímulo para as

\footnotetext{
${ }^{10}$ George Herbert MEAD nasceu em South Hadley, Massachussetts, em 1863. Concluiu seu ciclo universitário no Oberlin College. Trabalhou poucos meses como professor sendo afastado por problemas disciplinares. Ingressou, em 1887, em Harvard, familiarizando-se com a obra de W. James e Josiah Royce. Em 1888, após concluir a graduação, vai à Alemanha, onde passa a estudar psicofisiologia, na Universidade de Berlim. Em 1891 é convidado por Dewey para lecionar no Departamento de Filosofia da Universidade de Michigan, deixando então, seu doutorado em Berlim. Em 1894, convidado novamente por Dewey vai a Universidade de Chicago. Morreu em 1931, em Chicago. As conferências e aulas de Mead foram publicadas sob o título de The Philosophy as the present (1932) e Movements of thought in the neneteenth century (1936), Mind, self and society (1934) e a coletânea The philosophy of the Act (1938).
} 
demais escolas experimentais. Acolheu também a experiência de Coronel Parker, escola na qual seus filhos estudaram, cuja pedagogia baseava-se na escola como casa-modelo, comunidade democrática. Sua influência no campo educacional deve-se em parte à sua esposa. Outra pessoa que o influenciou foi Ella Flagg Young, superintendente do sistema escolar público de Chicago, pela sua tônica no respeito à integridade mental dos estudantes. Deve a Jane Addams, membro da Hull House, a fé nos princípios democráticos vivenciados nessa associação, baseada em relações de recíproco auxílio. (Cf. Amaral, 1990, p. 46) Participou ativamente dos trabalhos da Hull House, tendo a oportunidade de conhecer os problemas sociais e econômicos causados pela urbanização, pelo rápido progresso tecnológico e pelo crescente afluxo de imigrantes.

A integração da Escola-Laboratório à Universidade foi, para Dewey, uma intervenção autoritária do Presidente da Universidade, uma vez que este não o consultou. Dewey pediu sua demissão, procedimento adotado por E. F. Young. Neste período Dewey retoma suas discussões sobre lógica expressas no livro Studies in Logical Theory, publicado em 1903. Datam deste período seus primeiros escritos sobre teoria educacional: Meu credo pedagógico (1897), A escola e a sociedade (1889), A criança e o currículo (1902) e A situação educacional (1902).

Em 1905, ingressa como professor na Universidade de Columbia, em Nova York, lecionando também no Teachers College, onde permanece até 1930. Neste novo ambiente universitário, trabalha com doutorandos e, por influência de Woodbrige, partidário da doutrina aristotélica, concebe a teoria metafísica baseada em princípios empiricamente verificáveis desenvolvidos na obra Experience and Nature (1925). Neste período publicou também as seguintes obras: Reconstruction in Philosophy (1920), The Quest for Certainty (1929).

Após 1930, continua trabalhando na redação de inúmeros escritos. Participou intensamente da vida pública na defesa de causas progressistas. Em 1937, presidiu a comissão de investigação das acusações contra o líder comunista Leon Trotsky, concluindo por sua inocência. Em 1942, defende a liberdade universitária, diante da proibição de Bertrand Russell de lecionar no City College de Nova York.

As principais viagens de Dewey nesse período, acompanhado de sua esposa, são as seguintes: Japão, China (dois anos), Turquia (1924), México (1926), Rússia (1928). Viajou também à Europa, logo após sua demissão de Chicago. Essa viagem marcou profundamente o casal pela perda de um filho. 
A 2 de junho de 1952, Dewey faleceu em Nova York, com 92 anos de idade. As últimas obras do autor são: Arte enquanto Experiência (1937) e Lógica: Teoria da Investigação (1937). Nesta obra, Dewey afirma a grande contribuição de Peirce:

Os leitores que são familiarizados com os escritos lógicos de Peirce notarão minha grande dívida a ele nas posições tomadas em geral. Quanto a minha informação, ele foi o primeiro a escrever sobre lógica para fazer inquirição, e seus métodos constituem a fonte primeira e última em matéria de lógica. (Dewey, 1950, p. 5)

A partir de sua atuação pedagógica, Dewey criou uma escola de pedagogos, com William Kilpatrick, Harold Rugg, Boyd H. Bode, Carleton Washburne, entre outros. No Brasil, sua influência se deu a partir do movimento escolanovista, sobretudo através de Anísio Teixeira ${ }^{11}$ e Lourenço Filho.

Conforme Dewey salientou em seu relato autobiográfico e que pudemos identificar nesta introdução, ele denominou sua filosofia como sendo instrumentalista, por falta de uma palavra melhor, para designar seu intento de construir uma lógica como um efetivo método da inquirição. Esta denominação trazia também a sua trajetória de vida, o progresso de seu pensamento escandalizado diante quebra abrupta da continuidade expressa nos dualismos no ponto de vista da lógica e no método da ciência e da moral. M. G. White ajuda a compreender o movimento operado por Dewey:

O último instrumentalismo de Dewey marca o período durante o qual qualquer hegelianismo tradicional que permaneceu em seu pensamento, permaneceu a despeito (apesar) do seu próprio esforço. A unidade orgânica da idéia e do fato deu lugar à unidade da teoria com a prática; as contradições entre tese e antítese passaram a ser os elementos conflitantes numa situação problemática; a Razão Absoluta caiu diante da inquirição. (White, 1977, p. 152).

Este relato de fatos biográficos que influenciaram sua vasta produção teórica será complementado com uma discussão sobre o pragmatismo, que faremos a seguir. Analisaremos a seguir o pragmatismo de Dewey.

\footnotetext{
${ }^{11}$ Sobre a relação de A. Teixeira com Dewey, ver o trabalho de análise e sistematização de sua obra desenvolvida por Geribello (1973)
} 


\subsubsection{As origens do instrumentalismo}

John Dewey figura como um dos expoentes do pensamento pragmático norteamericano, por ter desenvolvido idéias originais sobre o conhecimento. Dentro desta vasta área de discussão tomamos como preocupação fundamental investigar como ele compreende esse problema, para depreender daí a dimensão conceitual em suas formulações, constituindo assim a primeira parte deste trabalho. Vamos começar buscando compreender como ele se apropriou das sugestões darwinistas.

Dewey encontra apoio teórico no modelo biológico darwinista de adaptação dos organismos vivos ao seu ambiente natural, para fundamentar o caráter ativo, inteligente, interativo e natural da atividade do homem. Como mencionamos nos dados biográficos do autor, este modelo servirá de base para Dewey formular os conceitos de sua filosofia. Diz o próprio Dewey:

[...] tenho a impressão que desse estudo derivou um sentimento de interdependência e de unidade inter-relacionada que infundiu formas às inquietudes que, anteriormente tinham caráter incipiente e criou um tipo ou modelo de concepção das coisas ao qual deveria conformar-se o material de todos os campos. Ao menos subconscientemente, eu fui levado a desejar um mundo e uma vida que tivesse as mesmas propriedades que o organismo humano, conforme a imagem dele derivada do estudo do tratamento dado por Huxley. (Dewey, 1930, p. 13)

Retomando a discussão iniciada sobre a psicologia social, Schneider aponta a contribuição de Darwin para a reconstrução filosófica do pragmatismo e do pensamento de Dewey em especial:

[...] a nova biologia trazia excelentes instrumentos de análise: "a adaptação ao meio", "a variação espontânea", "a luta pela existência", "o valor da sobrevivência", todos esses conceitos eram ao mesmo tempo teleológicos e físicos, que poderiam prontamente ser aplicados a todas as fases da cultura e à crítica de todas as instituições. O método genético ofereceu um programa (...) que transladou o centro do interesse evolucionista dos problemas da origem humana e dos planos divinos aos problemas da vida diária e da sociedade contemporânea. (Schneider, 1950, p. 368)

Schneider destaca, em seu estudo, a contribuição do grupo de Chicago, entre eles Dewey e Mead, na análise social a partir da "lógica genética": "acentuaram a diferença qualitativa entre os atos ou hábitos sociais e a adaptação meramente fisiológica ao meio físico." (Schneider, 1950, p. 376). Dewey contribui com a psicologia social ao mostrar a importância das ocupações / interesses profissionais e morais na evolução da experiência humana. Afastando-se da psicologia das faculdades e da mera adaptação fisiológica, ele 
concebe o papel da psique nesse processo como um órgão a serviço do controle do meio ambiente, em relação com os fins do progresso vital. Dewey comenta, em um artigo publicado no periódico Philosophical Review, com o título "Interpretações sociais", em sua análise da psicologia social, que as atividades ocupacionais são determinantes na formação dos hábitos e proporcionam um modelo ou esquema de organização estrutural e de funcionamento da mente. Vejamos o texto de Dewey:

Se investigamos em qualquer grupo social as funções especiais a que concerne a psique, surgem em seguida as ocupações. As ocupações determinam os modos fundamentais de atividade, e por isso controlam a formação e o uso de hábitos. (...) As ocupações determinam os modos fundamentais de satisfação, os critérios de êxito e fracasso. Daí que proporcionam as classificações e definições de valor operante; controlam os processos do desejo. Ainda, decidem que classes de objetos e relações são importantes e, por conseguinte, fornecem o conteúdo material da atenção e as qualidades que são significativamente interessantes. As direções impressas à vida psíquica se estendem assim às características emotivas e intelectuais. Tão fundamental e penetrante é o grupo das atividades ocupacionais que proporciona o esquema ou modelo da organização estrutural dos traços da psique. As ocupações integram os elementos especiais em um todo funcional. (Dewey, 1898, p. 629)

Em seguida, levanta o problema relacionado à formação do conceito como instrumento: "O problema imediato da psicologia genética é, portanto, mostrar como a adaptação puramente pessoal e imediata do hábito à satisfação direta se transforma no selvagem, pela introdução de fins e instrumentos em objetivos generalizados e impessoais." (Dewey, 1898, p. 629). Desta forma, Dewey descarta a psicologia como uma ciência dos estados da consciência e confere a ela a função de investigar as formas da ação, ou seja, dos contínuos reajustamentos dos hábitos e impulsos diante das circunstâncias - o ambiente sempre novas das quais emergem os significados. Na formulação mais elaborada da sua posição naturalista expressa na obra Lógica: Teoria da investigação, ele coloca da seguinte forma este problema: "Como ocorre que ao desenvolver-se o comportamento orgânico em investigação controlada se produz a diferenciação e a cooperação entre as operações observacionais e conceituais?” (Dewey, 1960, p. 39)

Num ensaio chamado “A origem do Instrumentalismo de Dewey”, Norton White desenvolveu uma pesquisa detalhada sobre a mudança que Dewey fez do idealismo ao instrumentalismo nas décadas de 1880 e 1990. O estudo de White percorre desde os primeiros trabalhos de Dewey até a obra que marca definitivamente o instrumentalismo de Dewey, chamado Studies in Logical Theory. Algumas contribuições de M. White foram introduzidas 
na primeira parte deste estudo, na apresentação da vida e obras de Dewey. Recorremos novamente a este estudo, para extrair a discussão deweyana sobre conceito.

Dewey começa a escrever sobre lógica no livro Psychology. Na verdade, sua posição nesta obra é idealista, seguindo o pensamento hegeliano. Dewey define pensamento nesta obra como sendo "o conhecimento dos elementos universais, ou seja, das idéias enquanto tais ou das relações." (Dewey, 1896, p. 202) Pensar é extrair os elementos ideais dos fatos tendo objetos gerais e propriedades. A única forma de pensar sobre objetos particulares é revesti-los conceitualmente. E como Dewey pensa o conceito nesta época?

Dewey discorda da concepção de conceito dos fisiologistas, porque não distinguem entre a coisa e sua função. Por exemplo, ao discorrer sobre o coração, eles não se decidem sobre o que se propõem a falar, ou seja, de uma coisa ou de sua função. Ora falam do coração como uma coisa isolada, com certa forma e tamanho, composto por certas fibras, ora, falam de um membro numa unidade em conexão interna.

Dewey introduz o problema da concepção afirmando que primeiramente uma imagem está associada ao conceito. Trata-se de um estado mental ainda, uma mera existência que não se pode chamar de conceito, como faziam os nominalistas. A imagem mental desempenha papel importante para a noção de conceito de Dewey neste período: "a força que uma imagem particular tem de significar ou transportar certo significado ou valor intelectual (...) o conceito é alguma coisa que a imagem faz, algum significado que ela transporta." (Dewey, 1896, p. 128) Dewey identifica a imagem com a percepção relacionando em seguida a percepção e concepção. $O$ conceito resulta da percepção realizando inteiramente o significado implícito nela. De que forma? Traçando um plano ou uma especificação, de acordo com a qual as coisas existem. Por exemplo, ao citar o caso do triângulo, Dewey diz: "O conceito de 'triângulo', em outras palavras, é o jeito com que três linhas são colocadas juntas; é um modo ou forma de construção." (Dewey, 1896, p. 129) Dewey adere à teoria construtivista das definições matemáticas. A definição construtivista oferece a origem, a gênese, as relações e produção das coisas. Dewey diferencia a percepção da sensação, atribuindo a esta a qualidade de uma mera posse. Entretanto, a percepção consiste num estágio inicial de conhecimento, a origem do conhecimento cujo desenvolvimento e resultado podem ser formulados em um conceito. A percepção é uma forma ativa de integrar várias experiências. O pensamento transforma a percepção desenvolvendo os elementos latentes nela. Dewey postula, assim, a continuidade entre percepção e concepção, mas a partir das premissas idealistas, antepondo-se às teorias dualistas. Ele consegue articular na definição 
construtivista de conceito três tendências com as quais vinha trabalhando: a ênfase hegeliana sobre a mudança, a darwiniana sobre a origem e o seu interesse pela educação. Na obra Applied Psychology (1889) ele desenvolve o aspecto educacional cunhando seu lema "Aprender a fazer para conhecer e conhecer fazendo". Estas idéias são precursoras de seu instrumentalismo, baseado na união da teoria e prática.

Dewey retoma esta discussão no ensaio que leva o título de Studies in Logical Theory $^{12}$ (1903). O livro é fruto do trabalho de Dewey sobre lógica: cursos de lógica que ministrava na Universidade de Chicago e do estudo de lógicos como Mill, Lotze, Bosanquet e Bradley.

Dewey inicia o seu estudo nesta obra apresentando a idéia central de sua teoria que é o princípio da continuidade, que nega a ruptura brusca da experiência ou a visão dualista da mesma. De acordo com sua compreensão, o pensamento vem depois de alguma coisa, de fora de alguma coisa e por causa de alguma coisa. "Em outras palavras, a reflexão aparece como traço dominante da situação, quando existe alguma coisa a importar seriamente, algum problema, devido a alguma discordância ativa, dissidente, conflitante entre os fatores de uma prévia experiência não-intelectual." (Dewey, 1953, p. 11) O pensamento procede de alguma atividade e continua em outro tipo de atividade. Hegel na filosofia, e Darwin ciência natural evolucionista, conceberam a realidade como um processo sem fim de acontecimentos sempre novos, todos eles em continuidade uns com os outros. O conhecimento é somente um acontecimento peculiar no meio de tantos outros, que tem suas condições específicas nos eventos que precedem e que por sua vez reage sobre os que seguem. O pensamento é compreendido como "um acontecimento específico no movimento das coisas experienciadas que tem suas ocasiões e exigências próprias e específicas, e seu lugar próprio e específico." (Dewey, 1953, p. 127) O princípio de continuidade é empregado por Dewey para dispensar a idéia de lógica pura de Lotze e outros lógicos. Esta lógica se baseia na noção de pensamento puro, adotando a premissa dualista que separa radicalmente o pensamento de seu objeto. Dewey critica o pressuposto inadequado da lógica pura: a existência de um método a priori para descobrir alguma coisa sobre o pensamento. Ou, ainda, que a formulação do critério para o bom pensar se dá apenas examinando o próprio pensar. Os lógicos se preocupam com o 12 Dewey incorporou esta obra na publicação da obra Essays in Experimental Logic (1916), conforme
informações do prefácio. Utilizaremos a versão inglesa desta obra publicada em 1953. 
valor, as distinções e relações absolutas do pensamento, como se fosse uma estrutura inerente já possuída, a ser trazida à consciência, e não com a gênese e o ciclo histórico do pensamento.

Dewey trabalha a lógica como uma ciência empírica a ser construída pela investigação empírica sobre o pensamento. Ele argumenta que o pensamento é resultado da evolução tal como tratado pela biologia. Este fato continua relegado pelos lógicos: "é espantoso que em face do avanço do método evolucionário na ciência natural, qualquer lógico possa persistir na afirmação de uma rígida diferença entre o problema da gênese e o da análise, entre história e validade.” (Dewey, 1953, p. 14). E continua mostrando a importância de como a história natural tem tratado a questão da origem do pensamento, de acordo com sua interpretação da visão darwiniana: "cada distinto órgão, estrutura ou formação, todo grupo de células ou elementos (...) como um instrumento de ajustamento ou adaptação a uma particular situação ambiental.” (Dewey, 1953, p. 15) Desta descoberta, o autor infere que o pensamento é um instrumento de ajustamento a uma situação ambiental, em que os fatores dela são mais ou menos incompatíveis entre si, exigindo uma remodelação e reorganização dos seus elementos. Assim, o pensamento intervém reorganizando os significados, para dar ou restaurar a unidade integrada e coerente da experiência tornando-a eficaz. Assim, o julgamento de uma atividade como boa ou válida se dá pelo grau de ajustamento ou não, isto é, pela extensão em que consegue atingir seu fim. Daí, o critério para julgar o pensamento como bom ou válido é o ajustamento que consegue realizar. $\mathrm{O}$ argumento de deweyano toma como base a observação dos fatos na história natural pela psicologia ou da biologia que mostra que o objetivo natural de certas atividades é o ajustamento. Ajustamento não é o restabelecimento de uma harmonia previamente existente, nem pensamento é decifrar enigmas já resolvidos por uma mente absoluta que guarda as respostas em segredo. Em todos os casos em que o objetivo natural é atingido a atividade é considerada boa. O pensamento também é tomado na observação destes fatos de forma empírica. Portanto, o método implica em adotar o ajustamento como critério de validade básico. O objetivo do pensamento é resolver a situação de conflito. Isto significa transformar a situação, introduzindo novos elementos não conhecidos anteriormente. Atingir esse objetivo é o padrão de sucesso. Assim, o pensamento é um processo de dúvida-investigação. O objeto do pensamento é uma situação de conflito que antecede e evoca o próprio pensamento; os dados emergem da própria situação no processo de investigação; o seu objetivo é o estágio final no desenvolvimento da investigação, que culmina com uma significação verificada praticamente. Portanto, o pensamento tem papel instrumental e funcional. Para desenvolver esse processo, Dewey se 
propõe rediscutir os conceitos que considerou lógicos, a partir dos procedimentos da investigação.

A análise de Schneider também aponta que Dewey desenvolve a teoria instrumentalista das idéias na obra Studies in Logical Theory (1903). Sobre esse trabalho de Dewey, comenta:

Ao mostrar que as idéias, abstrações ou 'objetos lógicos' desempenhariam um papel específico na experiência, a saber, o de clarificar atividades confusas, Dewey pode evitar o dualismo de Lotze, de pensamento contra realidade, sem afirmar a doutrina idealista de que a realidade é pensamento. Isso veio a significar para Dewey e seus colegas, não somente a emancipação da teoria do conhecimento do idealismo, como também, de toda classe de metafísica. Tinham assim uma ciência da inteligência. (Schneider, 1950, p. 517)

A lógica, como o processo dúvida-investigação de uma situação de conflito a ser harmonizada, foi a fórmula que Dewey encontrou para mostrar que a função dos conceitos é prática. O lógico e o prático estão unidos organicamente na função simbólica ou conceitual, e não opostos uns aos outros. A formulação vale para todos os campos inclusive para a ética. Esta é a posição que caracteriza o pragmatismo de Dewey como expresso em artigo publicado, em 1903, sob o título de Logical Conditions of a Scientific Traitment of Morality:

O ponto de vista exposto aqui é, por certo, decididamente pragmático. [...] O que pretendo sustentar é justamente o oposto [Dewey refere-se ao comentário anterior: lógico e o prático se opõem um ao outro], a saber, que o lógico é expressão orgânica e inerente do prático, e é daqui que provêm suas próprias bases e propósitos lógicos quando funciona praticamente. Não trato de mostrar que o que chamamos 'ciência` está limitado arbitrariamente por considerações éticas externas e que, portanto, a ciência não pode intrometerse dentro da esfera ética; mas, precisamente, o contrário, a saber, que sendo a ciência uma maneira de controlar nossas relações ativas com o mundo das coisas da experiência, a experiência ética necessita, em forma extremada, de semelhante regulação. E por 'prático` entendo somente o cambio regulado nos valores experimentais. (Dewey, 1903, p. 517, aspas e itálico do autor)

O erro filosófico que Dewey procurou evitar foi de colocar o estático e sem mudança acima do movimento e da mudança, conceber o conhecimento como um conjunto de verdades e certezas absolutas, a moral como obediência de princípios ou fins também absolutos, e tentar construir a realidade em todos os aspectos através de elementos fixos e acabados.

Dewey comenta os descaminhos que o temo prático "practical" estava tomando, especialmente quando entendido como "fim prático" ou "satisfação das necessidades práticas" ou algum tipo de "utilidade" definida do material do conhecimento. Para evitar estas concepções errôneas, Dewey se posiciona da seguinte forma: "Eu agora afirmo que o termo 
'pragmático' (pragmatic) significa somente a regra de se referir a todo pensamento, cada consideração reflexiva, às conseqüências do significado final e teste.” (Dewey, 1953, p. 332) E na continuidade, Dewey explica como esta questão deve ser entendida no pragmatismo que defende, denominado instrumentalita:

$\mathrm{Na}$ versão lógica do pragmatismo denominada instrumentalismo, ação ou prática desempenha, realmente, um papel fundamental. Mas ele não diz respeito à natureza das conseqüências, mas à natureza do conhecimento. (...) instrumentalismo significa uma teoria comportamental do pensamento e conhecimento. Significa que o conhecimento é literalmente alguma coisa que fazemos; que a análise é finalmente física e ativa, que o significado na sua qualidade lógica é pontos de vista, atitudes e métodos de comportamento sobre fatos, e que a experimentação ativa é essencial para a verificação. Colocando de outra forma, considera-se que o pensamento não significa algum estado transcendental ou ato introduzido subitamente dentro de uma cena natural prévia, mas que as operações do conhecimento são respostas naturais do organismo, que constitui conhecimento em virtude da situação de dúvida na qual ele surge e em virtude do uso da investigação, reconstrução e controle sob o qual é colocado. (Dewey, 1953, p. 331-332)

O pensamento é instrumental para o conhecimento e para a verdade e é um objeto formado do mesmo objeto ao qual é aplicado. O objeto do conhecimento não é algo com que o pensamento começa, mas com o qual termina. O pragmatismo de Dewey representa o curso genético-histórico da concepção.

Apoiados na leitura de Ratner, encontramos na obra mencionada - Studies in Logical Theory - o princípio fundamental ou o modus operandi do qual Dewey se serve para construir sua filosofia. O método extensivo e efetivamente usado é descrito por Dewey da seguinte forma: "É necessário trabalhar para trás e para frente no meio do amplo e estreito campo, transformando todo incremento por um lado em método de trabalho sobre o outro e, através disto testá-lo." (Dewey, 1953, p. 103) O modo de agir de Dewey reflete este duplo movimento dirigido pelo testar para todo incremento obtido. Funcionou para descobrir novos indícios, contribuindo para soluções e novos problemas, num processo de acumulação e correção do processo. Diz Ratner:

[...] este processo acumulativo e corretivo é a matriz natural pela qual se desenvolvem novas variedades de método empírico. Pois, o método empírico não consiste de uma única e linear regra. Ele é multidimensional e multipotencializado, adquirindo diferentes formas específicas através do uso em diferentes situações específicas e revelando novos poderes em cada novo caminho em que é usado. (Ratner, 1939, p. 56)

Dewey adota e adapta o método empírico para a filosofia. A justificação da adoção vem através dos frutos que seu uso produz. O uso do método pode ser considerado pela 
natureza da atitude do filósofo tomada em relação ao seu trabalho: o pressuposto da atitude empírica é de natureza aberta (overt), através da qual o filósofo se identifica como um ser humano entre os outros, um trabalhador dentre os outros trabalhadores, e identifica seu campo de trabalho com um campo dentre os outros, sendo ambos funcionalmente inter-relacionados entre si.

Ratner identifica e classifica o pragmatismo de Dewey em três círculos concêntricos:

A primeira área, em direção ao círculo interno, é ocupado pelo pensamento reflexivo, pela lógica, ou o que Dewey chama de investigação. Na segunda área estão os modos típicos da experiência humana, tais como o prático e o utilitário, a estética, a religião, ético-social, científico. A terceira área é aquela do mundo sócio-cultural, a sociedade nas suas formas organizadas e institucionais, o mundo que gera o que nós simplesmente e bastante corretamente chamamos de 'questões sociais.' (Ratner, 1939, 49-50, aspas do autor)

O objeto primário da investigação filosófica é o campo contínuo e interconectado da experiência.

A partir desta compreensão de lógica, do princípio de continuidade e da sua oposição ao pensamento constitutivo, transcendental, puro, formal, Dewey havia lançado as bases de sua filosofia e um programa implícito a ser desenvolvido e reconhecido posteriormente como instrumentalismo.

O pragmatismo de Dewey não concebe a verdade como substantiva. Compreende a verdade sempre com a conotação de verdadeiro, no sentido qualitativo, ou seja, preocupa-se com os procedimentos instrumentais que permitem avaliar se uma crença, proposição, teoria ou conceito é verdadeira ou falsa, dentro da experiência, e permite a tomada de decisão se é útil acreditar ou não. Acrescenta Amaral: "o verdadeiro é o que é útil, valioso, fomentador da vida." (Amaral, 1990, p.165).

Ao recusar a teoria da verdade como correspondência, que implica a idéia de representação (uma representação exata é verdadeira e a uma inexata é falsa), o Pragmatismo busca uma referência prática, ou seja, se algo faz diferença, faz a diferença na prática, nas mudanças que é capaz de operar.

O pragmatismo deweyano concebe o homem como um ser social, um ser de vontade e que age sobre o mundo, um ser de experiência compartilhada. O pensamento e o conhecimento são sempre mediados pelas ações e visam atender aos fins práticos de sua 
vontade, daí o peso que adquire a noção de experiência. Há uma forte influência do darwinismo nas concepções desses pioneiros do Pragmatismo.

A influência da nova lógica, genética e experimental de Darwin sobre a nova filosofia, significava, para Dewey, a seguinte transformação na filosofia: “A filosofia repudia investigações sobre origens e finalidades absolutas, a fim de explorar valores específicos e condições específicas de sua produção.” (Dewey, 1965, p. 13) Em conseqüência disso, continua Dewey, a lógica darwiniana introduz responsabilidade à vida intelectual:

[...] a filosofia deverá se tornar um método de localizar e interpretar os mais sérios dos conflitos que ocorrem na vida, e um método de projetar meios para tratá-los: um método de diagnóstico e prognóstico moral e político. (...) uma filosofia que tem a modesta pretensão de trabalhar para projetar hipóteses para a educação e a conduta da mente, individual e social, está, desse modo, sujeita a provar na prática as idéias que ela propõe. (Dewey, 1965, p. 18)

A reconstrução da filosofia significa que para realizar sua tarefa ela não poderá mais manter-se isolada da experiência humana, dos problemas reais da vida, diante da avalanche das transformações. Conforme nos diz Dewey: "Essa mudança não implica numa diminuição da dignidade da filosofia, não significa a remoção da filosofia de seu lugar altaneiro, sublime, para o de um rude utilitarismo, significa, isto sim, que sua função primacial é a de racionalizar as possibilidades da experiência, especialmente a da coletividade humana." (Dewey, 1958, p. 130) Compreende-se, portanto o empenho de Dewey de desenvolver reflexões originais nos diversos campos da investigação filosófica, como a lógica, a moral, a política e de esferas da atividade humana tão importantes, como ciência, educação e psicologia social.

Dewey encontrou no princípio biológico darwiniano uma forma de operar a síntese entre os dualismos de sua época que o importunavam desde o início de seus estudos, ou seja, o ambiente cultural da Nova Inglaterra, onde nasceu marcado pelas divisões e separações, tais como eu-mundo, alma-corpo, natureza-Deus. Contribuiu, também, a solução hegeliana da síntese do sujeito e do objeto, da matéria e do espírito, do divino e do humano, que lhe trouxe alívio. Desenvolveu a partir desses pressupostos a idéia de pensamento como um instrumento, com o qual o ser humano se equipa para lidar com o meio, tendo em vista a sua sobrevivência, e buscou abandonar toda filosofia calcada na metafísica. Propomos analisar com mais profundidade como Dewey elaborou a sua teoria naturalista do pensamento e do conceito. 


\section{CAPÍTULO II}

\section{A CONCEPÇÃO DE CONCEITO EM DEWEY}

\subsection{As relações entre o conceito, a experiência e a natureza}

O conceito de experiência é uma das categorias de base da filosofia deweyana, que constitui uma nova filosofia da experiência e do conhecimento, a qual suprime o dualismo entre estas duas dimensões e, por conseqüência, todos os demais dualismos, como inteligência e ação, teoria e prática, saber e fazer, espírito e corpo, trabalho e lazer, etc. A filosofia da experiência de Dewey consiste, segundo ele, "primariamente de relações ativas entre um ser humano e seu ambiente natural e social." (Dewey, 1979b, p. 301) Vamos aprofundar este conceito de experiência.

Para compreender a natureza da experiência é necessário compreender a combinação de dois elementos: um ativo, no qual a experiência é uma tentativa, ou seja, um experimento de alguma coisa, um agir sobre o objeto da experiência, em alguma direção circunstanciada no espaço e no tempo; o outro passivo, no sentido de que a experiência é um sentir ou sofrer as conseqüências do objeto sobre nós, originando uma significação. Há sempre uma combinação entre aquilo que as coisas nos fazem e aquilo que podemos fazer sobre elas, produzindo novas mudanças. Diz Dewey:

O organismo atua sobre as coisas que o rodeiam, valendo-se de sua própria estrutura, simples ou complexa. Em sua consequiência, as mudanças que produzem nesse meio circundante reagem a sua vez sobre o organismo e sobre suas atividades. O ser vivente sofre as conseqüências de seu próprio agir. Esta íntima conexão entre agir e sofrer ou padecer é o que chamamos experiência. $\mathrm{O}$ agir ou o sofrer, desconectados um do outro, não constituem nenhum dos dois a experiência. [...] Uma coisa vem a sugerir e a significar a outra. Temos, pois, uma experiência em um sentido vital e significativo. (Dewey, 1958, p. 110 e 111)

A simples ação-reação que resulta numa modificação física, desacompanhada da relação de causa-consequiência, é admitida como experiência, mas é desprovida de valor. A simples atividade diz Dewey é dispersiva, centrífuga, dissipadora. (cf. Dewey, 1979b, p. 152) Em outra passagem ele esclarece melhor a importância do elemento inteligente que acresce de valor à experiência: “1) A experiência é, primariamente, uma ação ativo-passiva; não é, primariamente, cognitiva. Mas 2) a medida e valor de uma experiência reside na percepção 
das relações de continuidades a que nos conduz." (Dewey, 1979b, p. 153, itálicos do autor) A presença do pensamento na atividade permite um fluxo e refluxo repassador de significação, desenvolvendo-se acumulativamente numa associação retrospectiva e prospectiva, na qual há percepção das relações ou continuidades a que nos conduz. A separação desses dois aspectos destrói o significado da experiência. Por exemplo, o ato da criança de pôr o dedo no fogo estará efetivamente se constituindo experiência quando se associa à dor sofrida como consequiência desse movimento, de tal maneira que pôr a mão no fogo passa a significar queimadura, dor, sofrimento, algo a ser evitado. A presença da inteligência no processo da experiência é condição para que ela seja significativa e para que resulte em aprendizado, ou seja, descobrir as relações entre as coisas que formará o conjunto de noções de cada indivíduo. (cf. Dewey, 1979b, p.153.)

Ao colocar o valor da experiência nas relações de continuidade que nos conduz, Dewey extrai o conceito de reflexão como sendo esse esforço intencional para descobrir relações entre a coisa que fazemos e a conseqüência que resulta, estabelecendo a continuidade entre ambas. Pensar é um ato cuidadoso e deliberado, que trabalha com as relações entre as coisas e a particularidade destas associações. Diz Dewey que pensar "é o discernimento da relação entre aquilo que tentamos fazer e o que sucede em consequiência. Sem algum elemento intelectual não é possível nenhuma experiência significativa” (Dewey, 1979b, p. 158) Considerando a proporção de reflexão que as experiências contenham, Dewey estabelece duas espécies de experiência: uma delas é o método de "experiência e erro", ou tentativa e erro, assim denominada pelos psicólogos. Fazemos coisas em tentativas diversas até atingir algo satisfatoriamente, adotando essa solução para a conduta posterior. Nessa associação entre certo modo de proceder e sua conseqüência, ignoramos como se associam, suas particularidades, seus elos. Como o discernimento é grosseiro, ficamos à mercê das circunstâncias. Na outra espécie de experiência, a reflexiva ou experimental, a observação é ampliada conforme declara Dewey: "Analisamos para ver com justeza o que existe entre as duas coisas, de modo a ligar a causa ao efeito, a atividade e a conseqüência." (Dewey, 1979b, p. 158) É nessa espécie de experiência que surge o elemento intelectual ao procurar descobrir minuciosamente as relações entre os atos e suas conseqüências. É possível, assim, ampliar o domínio sobre as coisas suprindo a falta de algumas condições necessárias para determinado efeito, ou mesmo eliminar algumas causas que produziriam efeitos indesejáveis. O elemento intelectual que surge do processo de descobrir as relações entre nossos atos e o que acontece em conseqüências deles aumenta o valor da experiência por tirá-la do fragmentário, do 
isolamento, e muda sua qualidade para experiência reflexiva por excelência. Acerca desta mudança no curso da experiência afirma Dewey: "Quando o ato de tentar ou experimentar deixa de ser cego pelo instinto ou costume, e passa a ser orientado por um objetivo e levado a efeito com medida e método, ele torna-se razoável - racional.” (Dewey, 1979b, p. 300) E o sentido de racional no curso da experiência é que "A razão deixa de ser faculdade remota e ideal, e significa todos os recursos por meio dos quais a atividade se torna fecunda em significações." (Dewey, 1979b, p. 304) A experiência não é mais empírica, mas experimental, ou seja, atividade prática dirigida pelo conjunto de concepções que a reflexão sugerir e processar, levando a produzir conhecimentos comprovados.

O pensar caracteriza-se por lidar com o elemento intelectual da experiência, e é este esforço deliberado para estabelecer a continuidade entre a ação e as conseqüências resultantes para, como diz Dewey, “[...] tornar explícito o elemento inteligível de nossa experiência.“ (Dewey, 1979b, p. 159). Desta forma, o pensar muda a maneira do proceder humano que passa a ser orientado por um fim em vista, ou seja, torna possível estabelecer os objetivos e ou valores da ação. Tal forma de proceder, ativo e inteligente, ocorre na criança, quando, diz Dewey, o infante "[...] começa a esperar, começa a considerar alguma coisa atual como sinal de alguma coisa que vai se seguir, está, embora de modo muito simples, a formar juízos. Pois toma uma coisa como prova de uma outra, reconhecendo, assim, uma relação entre ambas." (Dewey, 1979b, p. 159)

Os impedimentos para o crescimento da experiência são, para Dewey, a rotina os procedimentos caprichosos. A primeira porque é escrava dos "hábitos passivos", dos automatismos e deixam as coisas como estão e a segunda porque se prende ao ato momentâneo e despreza as associações das ações com as energias do ambiente. Ambas falham no mesmo ponto: "recusam-se a reconhecer sua responsabilidade pelas futuras conseqüências oriundas da ação atual.” (Dewey, 1979b, p. 160)

Estas responsabilidades somente podem ser conhecidas e assumidas pelo esforço da reflexão que capta o elemento inteligente que dá significado e continuidade à experiência: “A reflexão subentende também interesse pelo desenlace - uma certa identificação simpática de nosso próprio destino, pelo menos imaginativamente, com o resultado do curso dos acontecimentos." (Dewey, 1979b, p. 161)

Aparece de maneira muito forte no conceito de experiência de Dewey a importância do pensamento, da vontade, da intenção. Ele afirma que as coisas podem ser experiênciadas, mas sem que se componham como uma experiência, pois a distração e dispersão impedem a 
percepção das relações entre as coisas. (cf. Dewey, 1953, p.34) Temos uma experiência, diz ele, "quando o material experimentado segue seu curso até sua realização. Então, e só então, ela é integrada e delimitada, dentro da corrente geral da experiência, de outras experiências. (Dewey 1953, p.34) Uma experiência tem uma consumação, e não uma cessação, já que há continuidade entre as experiências e um acúmulo de significações graças à linguagem. "A experiência é o resultado, o sinal e a recompensa desta interação do organismo e o ambiente, que quando se realiza plenamente é uma transformação da interação em participação e comunicação.” (Dewey 1953, p. 22) O registro simbólico da experiência faz com que ela mesma seja objeto de experiência, permitindo sua comunicação. Na medida em que podemos fazer uma "experiência da experiência" (cf. TEIXEIRA, 1954, p. 7) podemos investigar suas leis para melhor conduzi-la. Decorre daí a sua profunda importância educacional.

\subsection{Experiência e Natureza}

Na obra já mencionada Experiência e natureza, Dewey se propõe fazer um estudo aprofundado da relação entre estes dois conceitos - experiência e natureza - como forma de apresentar sua concepção filosófica autodenominada de naturalismo empírico ou empirismo naturalista, ou ainda humanismo naturalista. Sua meta é desenvolver o método empírico em filosofia, visando a descobrir algumas notas gerais do mundo da experiência e interpretar seus significados. Natureza, experiência e método estão interligados pelo princípio de continuidade. Daí resulta também a concepção de conceito do autor. Vamos perseguir esse caminho de reflexão do autor para compreender as relações que estabelece.

Dewey inicia sua reflexão estabelecendo as bases da relação natureza e experiência: a experiência é da natureza, e como tal ocorre na natureza e no organismo humano - que também é um objeto natural - representando como as coisas são experienciadas. (cf. Dewey, 1958, p. 4a). É pela experiência que o ser humano tem a possibilidade de continuar penetrando cada vez mais no coração da natureza: "A experiência chega assim a descer ao fundo da natureza; tem profundidade. Tem também largura e amplitude infinitamente elástica. Ela se estende. Este estender-se constitui a inferência." (Dewey, 1958, p. 4a). Assim, a experiência humana, em seu sentido mais geral, tem a característica de ser um progressivo autodescobrimento da própria natureza pelas capacidades inteligentes de inferir as relações. Daí decorre, para Dewey, a necessidade de discutir o alcance metodológico da experiência para a filosofia. 
A diferença entre uma filosofia que se pauta pelo método empírico ou não empírico reside na diferença feita no que é selecionado como material original. O método empírico, conforme desenvolvido por Dewey, toma a unidade integrada da experiência como ponto de partida para o pensamento filosófico. $\mathrm{O}$ material da experiência tem caráter primeiro e terminal para o método empírico, evitando que ele se ocupe de problemas artificiais, tais como, os dualismos. O método determina que as conclusões que a investigação filosófica elabora sejam consideradas produtos secundários das experiências que as originaram. Elas devem ser checadas ou testadas sendo confirmadas ou modificadas pela sua capacidade de introduzir uma nova ordem e claridade à própria experiência. Ao introduzir, assim, um novo objeto à experiência, este passa a fornecer um método para as novas situações. Além disso, pelo seu funcionamento nas experiências seguintes, os resultados filosóficos adquirem valor experimental para a experiência comum dos homens, evitando ser colocadas no "museu metafísico" (cf. Dewey, 1958, p.18 e 19)

Os outros métodos adotam como material original o resultado de uma reflexão que cindiu em dois o objeto da experiência e suas operações, ou seja, objeto e sujeito, espírito e matéria. O material da experiência é tratado como simples fenômeno ou aparência, ou, ainda, simples impressões. Tomam esta separação como se fosse algo originalmente dado e formulam seus problemas como forma de juntá-los. Partindo da premissa de que sujeito e objeto são entidades separadas e independentes, o pensador não empírico acaba tendo problema ao responder à questão sobre a possibilidade do conhecimento, pois este passa a ser um ato que não é nem natural nem empírico.

O método empírico, para Dewey, coloca a questão desta forma: busca registrar como e porque o todo se diferencia entre o físico e o psíquico e quais são os efeitos desta diferenciação, ou seja, quais são as conseqüências desta diferenciação na e para a experiência primária. Dewey explica as conseqüências deste procedimento: “distinguir na reflexão o físico e mantê-lo isolado temporariamente é entrar pelas ruas que conduz às ferramentas e tecnologias, à construção de mecanismos, às artes que resultam no despertar das ciências." (Dewey, 1958, p. 10) Tais construções tornam possível uma regulação melhor dos assuntos da experiência primária, além de enriquecer a significação e valor das coisas, a clarificação, a profundidade e continuidade. Assim, vemos que para Dewey a concepção do método empírico traz uma estreita conexão com o estudo das "tecnologias" ou dos instrumentos eficazes para lidar com as condições da vida e da ação, ou para regular a experiência. Sua referência são as ciências físicas, que desenvolveram objetos cada vez mais eficazes para 
fazer frente às vicissitudes da experiência. Negligenciar a conexão dos objetos da ciência com a experiência primária é torná-los indiferentes aos interesses humanos. Se tomados como fixos e finais em si mesmos "oprimem o coração e paralisam a imaginação.” (cf. Dewey, 1958, p. 11) A falta deste método devido ao isolamento das origens empíricas e do uso de instrumentos fez com que os resultados das investigações psicológicas constituíssem um mundo mental auto-suficiente e fechado em si e por si, um reino técnico e privado de conceitos filosóficos. Paralelamente, outro movimento concebeu os objetos físicos como completos e fechados em si. O resultado foi o dualismo mente e corpo, mundo físico e mundo psíquico que predominou na filosofia desde Descartes. Assim, natureza e experiência passam a ser nomes para coisas distintas e desconexas, a primeira consistindo exclusivamente de objetos físicos e a segunda equivalente à consciência subjetiva e privada. A separação por completa do sujeito do objeto é considerada por Dewey uma das grandes falácias que têm imperado na filosofia.

O uso do método empírico traz para a filosofia um novo problema em relação aos resultados da reflexão. A análise reflexiva exige uma separação temporária da experiência primária. Assim, os resultados da reflexão filosófica correm o risco de serem tomados em si e por si, realidades superiores de qualquer outro modo de experiência. Dewey assevera que o problema das filosofias têm sido adotar como pressuposto a identidade dos objetos do conhecimento e os objetos como reais em última instância. O caso das teses da escola cartesiana e de Spinosa ilustram a situação: a emoção, assim como a sensação, são pensamentos confusos que se tornam claros e distintos, realizando sua meta de ser conhecimento.

Dewey salienta a dimensão ampla da experiência. Existe sempre uma defasagem entre o que é conhecido e o que acontece: “o que existe realmente 'na' experiência se estende muito além do que é conhecido em cada momento." (Dewey, 1958, p. 20, aspas do autor) Neste sentido, ele critica o hábito arbitrário de identificar a realidade com o objeto do conhecimento, por eliminar o obscuro, o vago e os possíveis desenlaces das consequiências latentes:

É importante para a teoria filosófica estar consciente de que o distinto e evidente são os preferidos e por que o são. Mas é igualmente importante notar que a obscuridade e a penumbra abundam. Para cada objeto da experiência primária existem sempre potencialidades que ainda não estão explícitas; todo objeto patente está carregado de consequiências possíveis que estão escondidas, e no ato mais manifesto entram fatores que não estão explícitos. Por muito que esforcemos o pensamento, não podemos prever todas as conseqüências nem fazer delas uma parte expressa ou conhecida da 
reflexão e da decisão. Em face de semelhantes atos empíricos, o pressuposto de que a natureza é em si toda da mesma índole, toda distinta, explícita e evidente, sem possibilidades latentes, nem novidades ou obscuridades, é possível somente sobre a base de uma filosofia que traga em algum ponto uma linha arbitrária entre natureza e experiência. (Dewey, 1958, p. 21)

Esta pretensão de domínio cognitivo completo da natureza é denominada por Dewey de intelectualismo, ou seja, a pressuposição de que toda experiência de valor é inerentemente cognitiva, separando o conhecimento de seus resultados. Ele condena esta postura intelectualista por ser uma maneira autoritária de conceber a relação entre experiência e conhecimento, e a define da seguinte forma: “[...] teoria de que toda experiência é uma forma de conhecimento, e que todo objeto, toda natureza é, em princípio, para ser reduzida e transformada até ser definida em termos idênticos às características apresentadas pelos refinados objetos da ciência enquanto tais." (Dewey, 1958, p. 21). A tendência do intelectualismo é isolar e exagerar os traços característicos dos objetos conhecidos e definidos como realidade última a serem testados universalmente como objetos do conhecimento. Este pressuposto da ubiqüidade do conhecimento explica a negação à característica da individualidade humana, que faz as coisas serem amáveis ou depreciáveis, belas ou feias, adoráveis ou terríveis. Nega ou menospreza, assim, a qualidade dos objetos para a amizade e associação humana, para a arte e para a indústria. Não leva em consideração o fato da experiência primária, ou seja, as coisas são dadas, antes de serem coisas conhecidas. São para serem usadas, gozadas, suportadas mais do que coisas destinadas a ser conhecidas. "São coisas tidas antes de serem coisas conhecidas." (Dewey, 1958, p.21) Atribui a estas características o caráter de subjetivo ou fenomenal pois não podem ser reduzidos a objeto de conhecimento. O pressuposto é de que a natureza é algo "indiferente", "mecanismo morto" e as características valiosas e estimadas da natureza são transformadas em inoportunos problemas filosóficos. (cf. Dewey, 1958, p. 21) A posição intelectualista, outra forma falaciosa de fazer filosofia, não leva em consideração que o conhecimento é subordinado e se desvia do problema genuíno que é saber “[...] como, por que e qual o efeito das coisas experienciadas serem transformadas em objetos nos quais os traços conhecidos são supremos, e os emotivos e volitivos, acidentais e subordinados." (Dewey, 1958, p.22).

$\mathrm{O}$ autor defende a importância da experiência primária que se dá pelo processo de ação e reação, como fonte do conhecimento. Afirma que: "Se nós começarmos da experiência primária, ocorrendo principalmente como modos de ação e reação (sofrer) é fácil de ver com o que o conhecimento contribui, isto é, a possibilidade de administração inteligente dos elementos do fazer e do sofrer. (Dewey, 1958, p. 22) Administrar quer dizer controlar a 
experiência. Isto quer dizer também que este conhecimento inicial dado na experiência pode ser desenvolvido da condição de subsidiário para condição de característica dominante. Sua função é enriquecer os materiais brutos da experiência. Assim, para ele, todo conhecimento reflexivo é instrumental. Começa e termina na experiência bruta do cotidiano. O pensamento, ao executar as operações de abstração e generalização sobre as relações da experiência, retorna a ela acrescentando significados e aumentando o poder de regular nossas relações. (cf. Dewey, 1929, 219) Entretanto, o conhecimento deixará de ter sentido se perder o contexto onde está inserido, isto é, dos objetos da experiência onde adquire sua importância.

Dewey recorre às bases naturais, biológicas, para sustentar a importância da experiência primária para o conhecimento. Os progressos da fisiologia e da psicologia mostram haver conexão da atividade mental e sistema nervoso. Nas palavras do autor:

O cérebro e o sistema nervoso são primariamente órgãos de ação e reação; biologicamente pode se assegurar sem contravenção que a experiência primária é de tipo correspondente. Portanto, a menos que haja uma ruptura da continuidade histórico e natural, a experiência cognitiva deve se originar dentro daquela de tipo não cognitiva. (Dewey, 1958, p. 23)

Assim, o cérebro é o órgão que reorganiza continuamente a atividade de forma a manter a continuidade natural da experiência, e é a base para afirmar o caráter secundário e derivado do conhecimento. A atividade do cérebro é realizar as adaptações entre os estímulos do ambiente e as respectivas respostas aos mesmos. Há reciprocidade no processo de ajustamento, de forma que cada ato futuro seja modificado pelo que foi feito. Portanto, o conhecimento está ligado à atividade de reorganização da experiência, na qual o ser vivo participa ativamente, e não é uma coisa completa e isolada a ser contemplada ociosamente por um expectador sem interesse. $\mathrm{O}$ aumento da complexidade da atividade exige maior participação da inteligência devido à maior distância de tempo para a verificação e formação dos planos. Entretanto, algo só poderá ser chamado conhecimento "quando nossa atividade produziu de fato certas mudanças físicas nas coisas, as quais concordam com a concepção adotada e as confirmam (Dewey, 1979b. p. 371) Caso contrário, as idéias são apenas hipotéticas ou conjeturais. Prever as conseqüências futuras com base nas observações mais completas das condições presentes significa reconhecer a utilidade do pensamento. Ele acrescenta ao processo de experimentação elementos novos a partir da observação e previsão. Por sua vez, as consequiências que decorrem são acumuladas como instrumentos aptos a serem usados para formular predições e planos em situações similares no futuro, num processo acumulativo infinito. Esta é a função do conhecimento, segundo Dewey: "tornar 
uma experiência livremente aproveitável em outra experiência.” (Dewey, 1979b. p. 373) Oferece maior domínio sobre as experiências subseqüentes, podendo-se desejar, evitar, prevenir ou amenizar conseqüências; além disso, acrescenta um sentido à experiência, proporcionando maior satisfação intelectual. Reconhecer este fato implica numa reconstrução, no conteúdo e forma, da tradição filosófica que se afirmou no princípio oposto, senão dualista, entre conhecimento e experiência.

Outra questão que decorre da adoção do método empírico é a diferença que representa para o problema da relação entre o sujeito e o objeto do conhecimento e a universalidade da experiência cognitiva. O pressuposto da filosofia tradicional de ter a clareza do conhecimento completo do objeto exclui os objetos afetivos e volitivos, portanto, o sujeito. A idéia da onisciência de toda experiência cria distanciamento entre o sujeito da experiência e a natureza que é experienciada. $\mathrm{O}$ sujeito fica relegado à condição de estranho no mundo e o seu refúgio será uma intimidade de um espírito ou sujeito da experiência. Assim, a maneira de evitar esta separação entre a mente (centro do processo de experiência) e o mundo natural é, para Dewey, "[...] reconhecer que todas as modalidades da experiência são vias pelas quais alguns traços genuínos da natureza chegam a manifestar sua realização.” (Dewey, 1958, p. 24) Porém, quando os objetos cognitivos são favorecidos à custa das emoções e desejos, temos um exemplo do princípio de ênfase seletiva, que introduz parcialidade e partidarismo na filosofia. Para Dewey, o fator seletividade ou escolha é o coração da vida do espírito, sua condição limite: "Ênfase seletiva, acompanhada de omissão e rejeição são a sístole e diástole da vida do espírito.” (Dewey, 1958, p. 25) Porém, nos assuntos ordinários e na investigação científica, a seleção de um material é feita em função de um propósito, enquanto o material omitido simplesmente não é relevante para o problema sobre o qual se trabalha. Da mesma forma, sua realidade e importância não são negadas em seu próprio contexto.

O diferencial do método empírico é que o princípio de seleção não deixa o sujeito dividido, à moda da seleção partidária, que se faz quando se privilegia o conhecimento claro e distinto do objeto. Isto porque, no método empírico, o critério que orienta a escolha não é o sujeito em si, mas o problema, problema sempre de um sujeito.

Dewey alerta sobre o problema da rigidez do critério de seletividade de muitas filosofias e da própria ciência. Certos objetos de preferência seletiva, geralmente arbitrária, são erigidos como realidades exclusiva, ou como a "pedra filosofal". No caso da ciência, por exemplo, a amizade e a poesia podem não ser consideradas realidades, quando se fixa o padrão inquestionável de realidade atribuída às propriedades matemáticas, das mecânicas ou 
eletromagnéticos, constituintes da matéria. No caso da tradição filosófica ${ }^{13}$, isso ocorre quando se fixam termos como permanência, essência, real, totalidade, ordem, unidade, racionalidade, certeza, o Ser, etc. Estes objetos selecionados como base ou como conclusões de um sistema filosófico representam simplificações artificiais da existência. Selecionar objetos de importância faz com que a escolha tenha um interesse moral, pois concerne, num sentido amplo, ao que é o bem. Objetos selecionados, por conta de que seu valor em dado contexto contêm características consideradas boas, são tomados como sendo o real e transformados em aspectos fixos do Ser, ou seja, têm um sentido superior, passam a ter exclusividade. A reflexão opera uma transubstanciação de um bem eventual numa classe de Ser que é, mesmo não existindo, ou não considerando o que está dado. Na formulação deweyana: "[...] transformação de uma idéia moral que deve fazer-se boa na prática em uma prévia metafísica da existência ou em uma teoria geral do conhecimento.” (Dewey, 1958, p. 50) A crítica a esta tendência se deve ao fato de ignorar a ação para efetivar o que aprova como o melhor e o como se provar a honestidade da sua escolha. Diz Dewey: “[...] ela converte o que é desejado em aspectos antecedente e final da realidade, que se supõe necessitar somente de garantia lógica para que goze de contemplação como verdadeiro Ser." (Dewey, 1958, p. 28) Esta é a terceira forma de falácia filosófica que privilegia os entes matemáticos, as essências estéticas, a ordem física pura da natureza ou Deus. A crítica tem também uma implicação social: os filósofos que fazem este tipo de reflexão "pertencem pelo seu status a uma classe ociosa aliviada das necessidades urgentes de lidar com as condições das coisas" (Dewey, 1958, p. 28, itálicos do autor) A operação da escolha é ocultada, disfarçada ou negada por propósitos não confessados no processo da reflexão. Embora empregando o método não-empírico, o produto destas filosofias não são totalmente errôneos para Dewey, inclusive porque não é possível prescindir totalmente da experiência. $\mathrm{O}$ problema foi ter substituído a imaginação não verificada por pensamento ou sabedoria, ou seja, deixar de enlaçar os resultados reflexivos com os assuntos da experiência primária e cotidiana. Estas filosofias desviaram-se do caminho de reflexão ampla por não retrocederem com os produtos refinados de suas reflexões para o contexto da experiência real, onde eles são comprovados, adquirem significação plena, e servem de luz e guia às necessidades empíricas

\footnotetext{
13 Alguns exemplos que Dewey menciona: “... se trata de Spinoza com sua segurança de que uma idéia verdadeira intrínseca em seu fundo de verdade; de Locke com usa "idéia simples"; de Hume com sua "impressão", do neo-realista inglês com seus dados atômicos últimos; do neo-realista americano com suas essências prontas." (Dewey, 1958, p. 27)
} 
que geraram os respectivos problemas. $\mathrm{O}$ que definem por realidade é "o que seria a existência se nossas preferências racionalmente justificadas estivessem tão cabalmente arraigadas na natureza de forma a esgotar e definir o ser íntegro desta, tornando-se desnecessária a busca e a luta." (Dewey, 1958, p.54). O resto (conflito, erro, etc.) pertence a uma ordem e grau do ser que é metafisicamente inferior - chamada de aparência.

Em contraposição a esta tendência, Dewey explica em que concerne o método empírico:

Nosso constante e inesquivável interesse é com a prosperidade ou adversidade, ao êxito ou infortúnio, ao sucesso ou fracasso, à realização ou frustração, ao bem e mal. Uma vez que somos criaturas com uma vida para viver, e nos encontramos dentro de um ambiente inseguro, somos construídos para observar e julgar em termos de se relacionar com o que é bem-estar ou mal-estar - o valor. (...) [do método empírico] apresenta alguma coisa $a$ ser efetuada, para ser levada a cabo por meio das ações que manifestam e autenticam a escolha. (Dewey, 1958, p. 28, itálicos do autor)

O método empírico localiza e aponta a operação da escolha no processo reflexivo sobre os eventos, protegendo da conversão das "funções eventuais em existência antecedentes." (Dewey, 1958, cf. p. 29) O emprego do método empírico não garante que todas as coisas relevantes serão encontradas, e, se encontradas, se serão apresentadas e comunicadas.

O método empírico declara quando, onde e por que a seleção foi feita. O seu propósito não é eliminar a seleção, mas torná-la menos arbitrária e mais significativa, assegurando a realização de uma intenção pura:

[...] o método empírico indica quando, onde e como se chegou às coisas que são objeto de uma determinada descrição. Ele põe diante dos demais um mapa do caminho pelo qual se viajou; em conseqüência, os demais podem se quiserem repetir a viagem pelo caminho para examinar as paisagens por si mesmos. Assim, os descobrimentos de uns podem ser retificados e ampliados pelos descobrimentos dos demais, com todas as garantias humanas possíveis de confirmação, ampliação ou retificação. A adoção do método empírico aporta, assim, à reflexão filosófica algo desta tendência cooperativa em direção ao consenso que caracteriza a investigação dentro das ciências. $O$ investigador científico convence aos demais, não com o plausível de suas definições nem a força de sua dialética, mas colocando diante deles a série precisa de indagações, operações e resultados em consequiência das quais certas coisas foram achadas. Convida aos demais a recorrer uma série semelhante, a fim de ver se o que encontram coincide com seus relatos. (Dewey, 1958, p 29-30)

Destas considerações sobre o método empírico decorrem duas exigências para a filosofia. Por um lado, diz Dewey, requer que 
[...] os métodos e produtos refinados sejam levados de volta à experiência primária em toda a heterogeneidade e plenitude, de forma que as necessidades e problemas dos quais derivaram e que devem ser satisfeitos sejam reconhecidos. Por outro lado, o método empírico exige a verificação: "que os métodos e conclusões secundários sejam trazidos de volta às coisas da experiência ordinária, em toda sua grossura e crueza para verificação. Deste modo, os métodos da reflexão analítica rendem materiais que formam os ingredientes do método de designação e denotação, na filosofia. (Dewey, 1958, p. 36)

Assim, o método empírico tem um serviço a prestar no estudo da filosofia como reconstrução da experiência: "Perseguindo empiricamente ele não será um estudo da filosofia, mas um estudo da experiência de vida por meio da filosofia" (Dewey, 1958, p. 37) Este estudo implica em desenvolver, desde o interior da experiência, métodos que assegurem uma direção e criem critérios de juízo e valor intrínseco do processo até então negado pelas filosofias. Por isso, ela tem amplo valor humano e libertador, na medida em que imprime direção inteligente à ação, emoção e ao relacionamento social.

A experiência está saturada com classificações e interpretações produzida pelas reflexões das gerações passadas e que parecem material fresco e ingenuamente empírico, mas são convencionalismos. São apelos ao preconceito e fanatismo. (cf. Dewey, 1958, p. 33) Se mesmo desconhecendo as fontes e a autoridade de quem as produziu elas forem consideradas preconceitos, independentemente de serem verdadeiras ou falsas, a filosofia seria a crítica dos preconceitos. A tarefa da filosofia é a de detectar e refletir sobre os resultados das reflexões passadas que se encontram soldados aos materiais da experiência de primeira mão, podendo torná-los fonte de enriquecimento. A filosofia desnuda intelectualmente os hábitos, os quais foram adquiridos na assimilação da cultura, sem terem sido inspecionados criticamente para ver do que são feitos e de que nos servem adotá-los, sem impedir o avanço inteligente da própria cultura. Caso contrário eles frequentemente ofuscam e distorcem:

Uma filosofia empírica é, de qualquer modo, algo como despir-se intelectualmente. Não podemos despojar-nos permanentemente dos hábitos intelectuais que contraímos e vestimos quando assimilamos a cultura de nosso tempo e de nosso lugar. Mas o progresso inteligente da cultura exige que abandonemos alguns desses hábitos, que os inspecionemos criticamente, a fim de descobrir sua constituição e seu uso para nós. Não podemos retornar à primitiva ingenuidade. Não obstante há uma ingenuidade cultivada dos olhos, dos ouvidos e do pensamento, a qual é atingível, mas só pode ser adquirida através da disciplina de um pensamento rigoroso. (Dewey, 1958, p. 37)

Esta tarefa visa ao seguinte resultado segundo Dewey: "clarificação e emancipação, quando eles são detectados e atirados fora.” (Dewey, 1958, p. 37) O desvio da experiência concreta, dentro dos cânones da filosofia transcendental (sensualista e materialista), significou 
perda de tempo e energia, desilusão da vida, obscurecimento das potencialidades de direção, regulação e gozo da experiência diária, negação da possibilidade de realizar o valor inteligente da busca para amadurecer a experiência, e imaginar que a vida pode ser fonte de alegria e felicidade. $\mathrm{O}$ método empírico cria e promove o respeito à experiência humana concreta e suas potencialidades.

Como vemos desta leitura, para Dewey, experiência é um conceito fundamental para a sua filosofia, e por isso, deve-se evitar dar ao termo um sentido sectário e provincial. Ela tem equivalência com os assuntos da história, vida e cultura. Dewey entende que a cultura é um todo complexo, dinâmico, diversificado e diferenciado nas formas da religião, magia, direito, moral, arte, ciência, filosofia, política, linguagem, família, etc. O fenômeno cultural tem um dinamismo próprio na medida em que os indivíduos como membros da sociedade interagem proporcionando reconstruções sintéticas. $\mathrm{O}$ fenômeno da cultura fornece o material precioso para a filosofia, uma vez que ela trata da existência. Desta forma, o material tem as características da própria existência, ou seja, é precário e perigoso: "Os traços da existência que são enfatizados pelo fenômeno cultural são o precário e o perigoso.” (Dewey, 1958, p. 41) A existência, ambiente onde nasce a cultura, gira em torno de um fato relevante que é a natureza instável e insegura do mundo, como diz Dewey: “[...] a evidência de que o mundo das coisas empíricas inclui o incerto, imprevisível, incontrolável e perigoso." (Dewey, 1958, p. 42) A característica que persiste em todos os objetos da experiência, como um dado primeiro, é o contraste:

O visível está assentado no invisível; e no fim o que é não visto decide o que acontece no que se vê. O que é tangível descansa de forma precária sobre o que não é tocado nem agarrado. $\mathrm{O}$ contraste e o mal ajustamento potencial do imediato, a óbvia e focal fase das coisas, com estes fatores indiretos e ocultos que determinam a origem e o curso do que está presente, são fatores indestrutíveis de todas e de cada uma de nossas experiências. Podemos qualificar de supersticiosa a forma de fazer frente ao contraste de nossos antepassados, porém o contraste mesmo não é superstição. É um dado primário de toda experiência. (Dewey, 1958, p. 43-44)

Esta mescla da estabilidade e segurança é a origem da filosofia. A tarefa da filosofia é a de desmembrar analiticamente e reconstruir sinteticamente a experiência. Numa análise da cultura filosófica, Dewey identifica que as diferentes filosofias adotam uma premissa comum: a negação do caráter de contingência do universo. Com isso, o espírito reflexivo fica sem um fio condutor, e o filosofar fica à mercê dos temperamentos, interesses e circunstâncias dos próprios filósofos. Desta forma, todos os esforços ficam circunscritos a um âmbito doméstico, que é o de conceber o mundo da existência real com o caráter de completo, acabado e seguro. 
Para isso recorrem a expedientes, como separar o mundo em dois blocos desconexos, como o da razão e dos mecanismos, coisas brutas e sensações, átomos e essências, consciência e exterioridade física. Daí resultam as diferentes metafísicas que pretendem dar evidência de mundos diferentes, mas sistematicamente exaltando o seguro e completo, sob a forma de um ser verdadeiro. Raramente o princípio de relatividade tem sido reconhecido como fundamento para constituir uma metafísica naturalista.

A filosofia grega, especialmente Platão e Aristóteles, desenvolvem o dualismo entre experiência e razão. Este fato remonta às próprias origens da filosofia ateniense, que nasce com a crítica aos costumes e à tradição, enquanto padrões para regular a vida, e encontram na razão a fonte de autoridade para as crenças.

Para Dewey, Platão concebeu a experiência como hábitos, costumes, ou conservação do produto líquido de uma série de outras vivências casuais. Na filosofia platônica, experiência significa a multiplicidade, discórdia, mudanças. Na leitura deweyana, Platão concebe a razão como um princípio de reforma, de progresso, de aumento de domínio que assegura o reinado da unidade, ordem e lei (cf. Dewey, 1979b, p. 263_266) E a razão permite ver como as coisas realmente são, rompendo com as limitações da experiência. Por isso, a inteligência racional deve comandar os destinos da polis, tarefa que para Platão caberia ao filósofo-rei. Os homens presos ao mundo das experiências - hábitos, apetites, impulsos instintivos, emoções - seriam contemplados com funções menos elevadas, na escala social de Platão.

Aristóteles chega perto deste ponto ao reconhecer a contingência. Ele trabalha com o conceito de natureza, comum aos primeiros filósofos-cientistas, como sendo a phusis. Etimologicamente, esta palavra mantém relação direta com o significado raiz da palavra crescer, que significa mudanças e alterações entre os extremos - nascer e morrer. É neste sentido, que Aristóteles emprega o adjetivo "físico" para designar a natureza. "Físico" foi empregado por Aristóteles, não como contrário ao mental ou psíquico, mas comportando estes aspectos, também sujeitos à mudança. Assim, a filosofia de Aristóteles é uma exposição sistemática e solução organizada para o problema da distinção e relação entre o fixo e permanente, e, a mudança e variação. (cf. Dewey, 1960, p. 83) A mudança é reconhecida como característica genuína de algumas coisas que são diferentes das coisas que exibem regularidade eterna. Mas, ele evita a mudança, imputando-a a uma deficiência inerente do Ser e contraposta ao Ser completo, auto-suficiente e que não muda. Ele identifica o fixo e regular com a realidade do Ser, e, a mudança e o perigo com as deficiências do Ser. Seu suposto é que 
existe uma divisão básica na natureza entre a mudança e o eterno. Assim, constrói sua física sustentada na necessidade que mede a dignidade e o grau de realidade, e na contingência e mudança, que medem os graus de deficiência do Ser. A lógica caminha na mesma direção, segundo Dewey: "Sua lógica é uma lógica da definição e classificação, cuja tarefa está acabada quando as coisas contingentes e que mudam são distinguidas do necessário, universal e fixo, sendo atribuído a elas uma espécie de coisa inferior." (Dewey, 1958, p. 48) Dewey concorda que a filosofia de Aristóteles está perto dos fatos empíricos, não sendo nem monista nem dualista, mas pluralista. E observa o caráter deste pluralismo: “[...] sua pluralidade cai dentro de um sistema gramatical, no qual cada porção é alocada dentro de um correspondente estatuto cósmico." (Dewey, 1958, p. 49) Assim, Aristóteles ao proceder com as definições, distinções e classificações do repouso e movimento, do completo e do incompleto, do ato e da potência, contribuiu para firmar a tradição que identifica o fixo e regular com a realidade do Ser. Desta forma, o conhecimento completo e compreensivo em si, fundado nos princípios, essências e hierarquias é fornecido pela razão, em contraposição com a experiência que subentendia o instável, a falta, a contingência, o desejo, sempre incompleta em si mesma. As coisas da experiência são muito instáveis para serem conhecidas, elas escapam à apreensão intelectual.

Dewey coloca da seguinte maneira o dualismo criado pela filosofia grega:

A razão era a faculdade com que o princípio e essência universais eram apreendidos, ao passo que os sentidos eram os órgãos que percebiam as mudanças - o instável e o variado em contraste com o permanente e o uniforme. $\mathrm{O}$ resultado do trabalho dos sentidos, conservando na memória e na imaginação, e empregando com a habilidade conferida pelo hábito, constituía a experiência. (Dewey, 1979b, p. 289)

Experiência é atribuída ao corpo, aos sentidos, composta de métodos rotineiros e autoritários, sujeita aos descaminhos da pretensão, da sorte, do fingimento e do cultivo das aparências. Seu caráter é material: mundo físico relacionado ao corpo. Desprovida da ciência e da razão, ela é identificada com os afazeres e sofrimentos humanos da vida particular, contingente, mutável, incerta e insegura. O melhor fruto que se pode tirar da experiência são os trabalhos manuais, através das artes da paz e da guerra. Em contrapartida, a razão lida com o imaterial, único, uniforme, coerente, harmônico, ideal, espiritual.

Quando a razão trata a natureza, concebe-a qualitativamente. A natureza consiste num todo, ligado e fechado em si, definido, acabado, completo e perfeito. O conhecimento de qualquer parte da natureza implica em localizar seu lugar neste todo. Dewey explicita esta questão da seguinte forma: "No esquema grego, o conhecer equivalia a colocar cada espécie 
relativa no todo, definido e identificado por sua própria essência, em relação com outras espécies dentro da Natureza como um todo final.” (Dewey, 1960, p. 111, itálico do autor)

A filosofia medieval deu continuidade a este dualismo relegando a experiência para a esfera das coisas mundanas, profanas, seculares, contraposta à contemplação dos objetos sobrenaturais.

O empirismo do século dezessete e dezoito opera a inversão da doutrina clássica das relações estabelecidas entre experiência e razão. O apelo à experiência representa um rompimento com a autoridade do método escolástico e dedutivo. A experiência ganhou o estatuto de "meio de adquirir conhecimentos", portanto, intelectual e cognitiva. Ela é responsável pela aquisição do material que serve de lastro e limite para as operações cognitivas. Para Bacon (1561-1626), é necessário recorrer à experiência como guia, abrindose às impressões, disposto a descobrir e inventar, visando a desvendar a natureza. Isto implica retirar o véu das concepções preconcebidas que encobrem a natureza e aprisionam a razão.

John Locke (1632-1704) desenvolve o empirismo sensualista, contrapondo-se à concepção de idéias inatas e colocando nas percepções sensíveis a fonte do conhecimento. $\mathrm{O}$ espírito recebe e associa as impressões sensoriais dos objetos do mundo exterior ou material, donde resulta o conteúdo do conhecimento. Locke concebe a mente como tabula rasa, ou seja, análoga a uma folha de papel em branco. A mente com certos poderes (atenção, observação, retenção, comparação, abstração, combinação, etc.) processa o material que provém dos sentidos, em formas definidas e organizadas, originando assim novas idéias, inclusive as concepções fundamentais da moral e matemática. Assim a elabora o conhecimento, que nada mais é do que expressão fiel das coisas da natureza.

A forma do empirismo pensar o processo do conhecimento, baseado na experiência passiva, termina por considerar o espírito como sendo puramente receptivo e passivo também. "Quanto mais passivo o espírito, mais verdadeiras serão as impressões que os objetos lhe causarem." (Dewey, 1979b, p. 294). O empirismo esquece-se dos elementos ativos e motores da experiência nos processos de construção do conhecimento. Assim, o empirismo fica distante da idéia de experiência da psicologia moderna, por não levar em conta a importância “primordial de 'respostas' ativas, que consistem no uso das coisas e no aprender as propriedades destas por meio da descoberta das conseqüências do seu uso." (Dewey, 1979b, p. 298). Da mesma forma, o empirismo não resiste à idéia de conhecimento do moderno processo científico, com seu método de experimentação que exerce o controle deliberado de certas condições. 
O esquema classificatório de separação aristotélico serviu de base para muitos filósofos. Kant (1724-1804) continua essa tradição, ao atribuir o múltiplo e o caótico ao reino dos sentidos, e tudo o que é uniforme e regular, ao reino da razão. O problema dialético de combinar sentidos e pensamento substitui os problemas concretos da existência, na qual o variável e o constante, o necessário e o incerto encontram-se em forma mista e variada.

Dewey argumenta que as chamadas "filosofia do fluxo" ou "metafísicas da mudança", desde Heráclito até Bergson, também se filiam ao reino do fixo e seguro. Elas deificam a mudança, tornando-a universal, regular e segura. Hegel coloca o devir como "um processo racional definido pela lógica e por um Deus absoluto.” Para Spencer, a evolução é mais um "processo transitório, através do qual se chega a alcançar o equilíbrio fixo e universal de um ajuste harmonioso". Em Bergson, a mudança é um "processo de energia divina, espiritual" (cf. Dewey, 1958, p.50)

Dewey simpatiza com a terminologia clássica que compreende a filosofia como amor à sabedoria, e a metafísica como o conhecimento das características comuns da existência, englobando, assim, tanto o incompleto e o instável na mesma classe do acabado e fixo. O amor à sabedoria é um interesse em encontrar as implicações que estes aspectos têm para a condução da vida. Este amor pelo conhecimento, pelo seu próprio valor, constitui um ideal moral. $\mathrm{O}$ apreço ao conhecimento se dá pela influência que exerce sobre o êxito e o fracasso na realização de um bem ou para evitar um mal. Faz parte da nossa própria estrutura prezar pelo conhecimento, ou seja, há uma relação inerente da mente com a verdade e com os fatos. Afirma Dewey, "o homem é naturalmente filosófico mais do que metafísico, ou, cientista frio que observa e descreve." (Dewey, 1958, p.51) Assim, a sabedoria é esta noção adequada e justa que se tem das condições e dos meios, em relação a um fim. Afirmar essa relação requer escolha e ação. Mas, a escolha e o esforço reflexivo são em si, também, fatos contingentes, ligados aos demais, na precária incerteza dos eventos.

Muitos filósofos subtraíram este fato, colocando a metafísica e a ciência dos fatos e da verdade como sabedoria, evitando a necessidade de exercitar e reconhecer a escolha. Tratase de uma técnica intelectual refinada, que relega o incerto e incompleto a uma situação de irreal e exalta o seguro e completo na classe do verdadeiro Ser. Este expediente mitiga a instabilidade da vida e inculca moderação; o agravamento do mal é tratado com consolo e compensações; o inacabado e incompleto justificam a busca do absoluto e final, procedem com classificações que dividem a existência no reino do natural e no reino do sobrenatural: o divino onipotente, onisciente, eterno e infinito, de um lado, e o homem e a natureza, no outro 
lado, como finitos, fracos, limitados, em luta e sofrendo mudanças. Este pretenso conhecimento da existência construído na imaginação é justificado, segundo Dewey, da seguinte forma: “[...] transpõem a percepção imaginativa dos objetos estavelmente bons em uma definição e descrição da realidade verdadeira, em contraste com a existência baixa e enganosa que, sendo instável e incompleta, limita-se a nos envolver na necessidade de escolher e lutar ativamente. (Dewey, 1958, p. 53)

O problema dessas formulações consiste no fato de separar os atributos das coisas que na natureza encontram-se sempre juntas e interpenetradas. Para Dewey, este fato é a origem da experiência que se constrói na relação necessidade e satisfação: “A união do perigoso e do estável, do incompleto e do recorrente é a condição de toda satisfação experienciada, tão verdadeiramente como das dificuldades e problemas. Ao mesmo tempo em que é fonte da ignorância, do erro e da decepção, é a fonte do deleite que traz consigo a realização." (Dewey, 1958, p. 62) Quando a realização é julgada boa, destaca-se e se afirma uma qualidade que é melhor por concorrer com o que é indiferente e divergente dela e que a coloca em perigo. A experiência de um objeto bom, em meio à mescla do regular e das resistências à estabilidade, dá a este objeto o caráter de ideal, digno de desejo e esforço para se conseguir. Mas, alerta Dewey, esta qualidade de ideal se dá apenas de forma retrospectiva, no contraste com as forças que visam destruí-la. Quando há desprendimento das condições de dúvida, ambigüidade e busca que engendraram uma solução do contexto circundante, ela retorna à condição de acidente. Assim a precária natureza da existência, que é a fonte do problema, é também uma condição indispensável do ideal. Na medida em que o ideal é desejado, em meio a um mundo ameaçador, ele cria a noção de perfeição. Entretanto, esquecemos a verdadeira origem do ideal: "Olvidamos que o que dá sentido à idéia de perfeição são os acontecimentos que criam o desejo" (Dewey, 1958, p. 63). Um mundo perfeito seria uma coisa dotada de existência bruta e imutável.

A carência, o desejo e à satisfação como sinais distintivos do ser natural vêm se tornando cada vez mais importante para algumas filosofias. Afirma Dewey acerca da relação entre carência e satisfação no processo da experiência:

Se a experiência humana há de expressar e refletir este mundo, ela deve ser marcada pela necessidade; tornando-se consciente das necessitadas e necessárias qualidade das coisas, ela deve projetar satisfação ou finalização. Independentemente da satisfação ser consciente, a satisfação ou não satisfação é uma coisa objetiva com condições objetivas. Significa realizar o que pedem os fatores objetivos. A felicidade poderá significar o ser consciente da satisfação e poderá ser sua forma culminante. Mas a satisfação não é subjetiva, privada ou pessoal: ela é condicionada por parcialidades e 
defecções objetivas e se tornar real através de situações objetivas e completas. (Dewey, p. 64, itálicos do autor)

Carência implica a existência do instável e contingente, de coisas que suprem a falta. Um mundo somente de necessidades teria existência limitada, nada seria necessário para nada. O necessário refere-se sempre a algo (continência) que o completa e que não comporta ser necessário em si e para si. Se tivéssemos um mundo em que tudo fosse completo, não haveria a necessidade de complementação entre as coisas. A própria necessidade careceria de sentido. Mas Dewey denuncia a rápida mudança de um universo de discurso para outro: da postulação da totalidade do Ser, passa-se a afirmar a existência das partes que são dependentes em propriedades e existência. Introduz-se, assim, a contingência no simples fato de determinar algo como parte.

A satisfação de uma necessidade não é algo mecânico. Exige a mediação da função natural inteligente ou do pensamento que restabelecerá a unidade. "A indagação reflexiva marcha, em cada caso particular, das diferenças à unidade, de uma posição indeterminada e ambígua a uma clara determinação, da confusão e desordem ao sistema.” (Dewey, 1958, p. 66) A posição indeterminada e ambígua é uma situação problemática ${ }^{\mathbf{1 4}}$ que obriga o pensamento a tomar forma reflexiva, a partir dos materiais oferecidos pelos sentidos. Isto mostra que o pensamento está relacionado com o organismo, como parte da natureza em suas articulações. Este é o ponto de partida do método empírico proposto à Filosofia:

Uma filosofia que aceita o método denotativo ou empírico aceita em todo seu valor o fato que o pensamento reflexivo transforma a confusão, a ambigüidade e a discrepância em iluminação, precisão e consistência. Porém também aponta a situação contextual na qual o pensamento ocorre. Observa que o ponto de partida é o realmente problemático e que a fase problemática reside em certa situação real e indeterminada. (Dewey, 1958, p. 67)

O meio para transformar esta situação duvidosa e incompleta em segura e determinada é, para o método empírico, "usar das coisas seguras e bem estabelecidas, que são exatamente tão empíricas e tão indicadoras da natureza das coisas experienciadas como o incerto. (Dewey, 1958, p. 67) Daqui resulta que o pensamento e a razão são acontecimentos naturais, ou seja, ocorrem dentro da natureza e operam com os objetos e relações da natureza. Afirma Dewey acerca da natureza da reflexão: “[...] o pensar não difere em espécie do uso dos materiais e energias da natureza, digamos o fogo e ferramentas, para refinar, reordenar, e dar

\footnotetext{
${ }^{14}$ Estudaremos com mais detalhes este conceito no final deste capítulo.
} 
forma a outros materiais naturais, digamos o ouro." (Dewey, 1958, p. 67) Emprega procedimentos que visam reorganizar deliberadamente o mundo da experiência, "aplicando o insatisfatoriamente confuso e indeterminado ao regular e estável e vice-versa." (Dewey, 1958, p. 60) O pensar nunca salta fora dos objetos empíricos ou naturais e temporais, nem são coisas somente pessoais e psicológicas, em contraste com o mundo objetivo da natureza, como ocorre com o idealismo racionalista, que transforma a lógica da reflexão numa ontologia do ser racional. A imaginação é, assim, parte da natureza: "é um órgão da natureza, pois representa a fase de apropriação de acontecimentos indeterminados, que se movem em direção a eventualidades que são atualmente apenas possibilidades. "Um mundo puramente estável não admite ilusões, mas também não se reveste de ideais.” (Dewey, 1958, p. 62)

Toda existência, incluindo as idéias e atos humanos mesmo que não projetados, são experimentos de fato: representa a conjunção de aspectos problemáticos com determinados. A experiência inteligente exige a deliberação das relações entre estes aspectos. Fala Dewey: "Ser inteligentemente experimental não é senão ser consciente desta interação entre as condições naturais, de forma a ser capaz de aproveitá-la, ao invés de estar a sua mercê." (Dewey, 1958, p. 70)

O que existe em um dado lugar e momento está sempre submetido à prova da força e resistência imposta pelo circundante. Nem o que é considerado mais estável foge das condições impostas pelas outras coisas. Afirma Dewey a respeito da mudança: "Uma coisa pode durar secula seculorum e, ainda assim, não ser eterna; ela ficará reduzida ao pó ante o dente roedor do tempo conforme excede certa medida. Toda existência é um acontecimento. (Dewey, 1958, p. 71) Para Dewey este é um fato que se pode simplesmente registrar e usar de forma a conhecer a medida, a proporção, a razão, os tempos de mudança.

Nesta ocasião, é oportuno fazer uma digressão, para aprofundar a relação entre mudança e coisa a partir do próprio texto deweyano:

Não existem mudanças que não entrem em uma 'coisa', - res -, e não existe coisa que não esteja vinculada, e portanto, se destaque como um estado ou condição. Quando um estado de coisas é percebido, a percepção-do-estadoda-coisa é um novo estado das coisas. Seu objeto é uma coisa no sentido idiomático de coisa, res, trate-se de um sistema solar, de uma constelação estelar ou de um átomo: uma interconexão diversificada e mais ou menos imprecisa de acontecimentos, que cai dentro de limites suficientemente definidos que os tornam aptos de serem traçados aproximativamente. (Dewey, 1958, p. 101) 
Para Dewey, há uma estreita relação entre acontecimento e coisa, conforme já vimos. Ele retoma esta mesma idéia, reforçando a idéia de resolução, conceito chave para entender a idéia de fins:

Todo acontecimento passa em quanto tal a ser outras coisas, de tal maneira que o que ocorre posteriormente é uma parte integrante do caráter ou natureza da existência presente. Uma 'coisa' (affair), res, está sempre em questão, mesmo que se trate de uma mudança química, da aparição da vida, da linguagem, do espírito, ou dos episódios que compõem a história humana. Cada um vem de outro e cada um, quando vem tem suas próprias qualidades imediatas iniciais imprevisíveis e suas próprias qualidades terminais similares. O posterior não se resolve nunca integralmente no anterior. O que chamamos como resolução é meramente uma reformulação de ordem, por meio da qual regulamos o passo do anterior ao posterior. (Dewey, 1958, p. 111)

A própria experiência bruta testemunha este fato, assim como as conclusões da física. Desta forma, toda situação ou campo de consciência é caracterizado por uma iniciação, uma direção ou intenção, e uma conseqüência ou significação. Não se trata de uma classe de propriedades singulares separadas da existência, e chamadas de psíquicas ou mentais, mas sim, das propriedades da consciência ou percepção. O estágio inicial é marcado pela antecipação, pode ser julgado à luz do curso provável ou das consequiências. Temos um processo serial de acontecimentos sucessivos, no qual cada um tem características de ser "expectante e comemorativo". Antecipar um resultado final é torná-lo um fim em vista, meta, propósito, predição que serve de plano para orientar o curso de acontecimentos. Os objetos que resultam de reflexão prévia, eleição deliberada e esforço dirigido podem ser considerados realizações, conclusões, planos, perfeições. Os objetos que resultam naturalmente, prescindindo da intervenção humana, são um término (terminus), um limite de fato. Dar-lhes um estatuto honorífico de planificação e realização, como faz a metafísica clássica, é ignorar e negar o ato de escolher, uma vez que procede escolhendo os fins do gosto e honra, dentre todos os outros fins. Na medida em que justifica a beneficência da natureza se torna apologética, seu otimismo é complacente.

Assim, no pensamento grego, os fins são possessões que se prestam à contemplação estética das formas, como complementação dos processos naturais. Em parte do pensamento moderno, os fins são criados de forma arbitrária, ou seja, o desejo pessoal comanda as operações de uma mente privada, que depreende, das intenções de um espírito infinito, cópias finitas. 
A velocidade das mudanças é variável. Algumas são lentas, e rítmicas adquirindo aspecto de estabilidade, enquanto outras são mais transitórias e irregulares. É desta relação de velocidade das mudanças da natureza, que Dewey formula os conceitos de estrutura e processo: "É de senso prático designar os eventos de ritmo mais lento e regular de estrutura e os mais rápidos e irregulares de processo. Estas denominações expressam a função de um em respeito ao outro“ (Dewey, 1958, p. 72, itálicos nossos)

A estrutura se refere a um conjunto de aspectos dos eventos que têm relações limitadas, em relação aos outros aspectos dos acontecimentos. As propriedades de certa ordem de acontecimentos mudam lentamente, limitando, dirigindo e ordenando outros eventos que mudam mais rapidamente. A estrutura de um a casa torna possível sua existência. Enquanto evita a desintegração da casa a estrutura é fixa, mas não é eterna, no sentido de que todas as outras mudanças relativas a sua construção, uso, etc. tenham que se submeter. Diz Dewey: "Estrutura é constância de meios, de coisas usadas para se obter conseqüências, não das coisas tomadas em si ou em absoluto. A estrutura é o que faz possível a construção realizada e não se pode descobrir ou definir senão em uma construção realizada, sendo a construção, naturalmente, uma evidente ordem de mudanças. (Dewey, 1958, p. 64) Quando a estrutura é isolada das mudanças que permitem certa ordem estável, ela se torna algo metafísico, misterioso, fantasmagórico.

Assim, a mudança também é o critério para compreender a matéria, negando o caráter de "entidade" e afirmando o de "ação":

[...] o que chamamos de matéria é esse caráter de acontecimentos naturais que está tão amarrado com as mudanças que são suficientemente rápidas para ser perceptível de forma a dar a estes últimos uma ordem rítmica característica, uma sequiência causal. Não é a causa ou fonte dos acontecimentos ou processo; nenhum monarca absoluto, nenhum princípio de explicação; nenhuma atrás ou embaixo das mudanças. (Dewey, 1958, p. 73)

Assim, estrutura e matéria estão submetidas à lei da ação e reação. "Tudo o que influencia nas mudanças das outras coisas muda a si mesmo." (Dewey, 1958, p. 73) A ciência natural baniu a idéia de atividade unidirecional, ou o "motor imóvel" da física grega, ao introduzir essa idéia de acontecimentos naturais, que têm como caráter a mudança com certa ordem regular e estável. Introduziu novos métodos de segurança, regulação e reconhecimento. Entretanto, os acontecimentos naturais são tão complexos e variados, que podem inclusive possuir características opostas. O complexo de acontecimentos, incluindo a matéria e o espírito, constitui a natureza. O espírito deve ser compreendido na relação ativa com seu 
ambiente. Qual é a função do espírito ou consciência? Reorganizar as atividades pela antecipação das conseqüências. É redirecionar a natureza, usando das próprias coisas para seguir seu caminho, usar das próprias luzes para se guiar na obscuridade.

O ser humano não está ilhado contemplativamente no mundo, nem a situação lhe é indiferente. Sua vida depende da arte de ajustar a confluência entre as coisas tais, como estrutura e processo, substância e acidente, matéria e energia, permanência e fluxo, unidade e multiplicidade, continuidade e descontinuidade, ordem e progresso, lei e liberdade, uniformidade e crescimento, tradição e inovação, vontade racional e desejos impulsivos, prova e descoberta, o atual e o possível. A reflexão existe como guia para a eleição e o esforço. Caso contrário a atitude de condescendência diante da existência tomaria conta como forma de compensação pelas angústias da vida. Assim, a tarefa da verdadeira sabedoria consiste em abrir e alargar os caminhos da natureza no homem: "descobrir na reflexão observadora e experimentadora o método de administrar os processos inacabados da existência, de forma que os bens frágeis tornem-se consistentes, os bens seguros sejam estendidos, e as promessas inseguras do bem que aparecem nas coisas experienciadas sejam mais liberalmente realizadas." (Dewey, 1958, p. 77)

\subsection{Conceito na concepção naturalista: natureza e instrumentos}

A natureza impõe ao homem forçosas condições para sua sobrevivência. A necessidade é o fator constante, mesmo que mude em termos de qualidade. O homem se vê forçado a observar, refletir, registrar os movimentos e possibilidades das coisas e acontecimentos naturais, para conseguir utilizá-los de forma a suprir suas carências e garantir a continuidade da vida. $\mathrm{O}$ trabalho é a forma de realizar com êxito atividades que operam com a natureza, de forma a extrair dela as coisas para as necessidades cotidianas. Assim, a necessidade é mãe das invenções, das descobertas e da reflexão consecutiva.

A mitologia retrata o trabalho como uma carga constante e penosa que recai sobre o homem em conseqüência da usurpação das prerrogativas divinas. Nesta condição o homem está satisfeito degustando a maçã. O trabalho é um castigo, mas é por meio dele que o homem se torna, como os deuses, conhecedores do bem e do mal. Se a festividade e o gozo dos bens naturais parecem espontâneos, o trabalho precisa ser justificado. Esta atitude humana está presente desde a mitologia até a economia política clássica. O trabalho é fonte de valor à custa do sacrifício oneroso, mediante uma consumação presente para obter um bem futuro. 
O trabalho implica a percepção das conexões entre as coisas e acontecimentos como meios e sinais anunciadores de outras coisas, tornando aquelas instrumentais para a aquisição destas. "Agudeza, sagacidade, inventividade, acumulação e transmissão de informações são produtos da necessidade sob a qual o homem trabalha para escapar ao confinamento direto de possuir e gozar, considerando as coisas em suas conexões ativas como meios e como sinais." (Dewey, 1958, p.122)

Como forma de reduzir a sobrecarga ocasionada pelo trabalho, o homem reveste as artes úteis e instrumentos com as lembranças das realizações. Por sua vez, estes materiais, aparelhos e modelos fornecerão os objetos para as artes cerimoniais e festivas.

Como resultado do trabalho temos as tecnologias, ferramentas, meios, agentes, a indústria. Dewey enfatiza que a natureza da tecnologia não é o imediatismo, mas a instrumentalidade das coisas e atos. A ferramenta se define pela qualidade de conexão ou vínculo de relações na natureza:

Os objetos e acontecimentos não figuram no trabalho como satisfações, realizações, mas em favor de outras coisas das quais elas são meios e previsão. Uma ferramenta é uma coisa particular, mas é mais do que uma coisa particular, visto que é uma coisa a que está incorporada uma conexão, um laço sucessivo da natureza. Possui uma relação objetiva como propriedade sua e que a define. Sua percepção, assim, como seu uso real, leva a mente a outras coisas. (...) Uma ferramenta denuncia que se percebem e reconhecem certos vínculos de sucessão na natureza. (Dewey, 1958, p. 122)

O homem pode pensar que as ferramentas estão em relação a si mesmo (mãos, olhos, etc.), entretanto as relações são com coisas externas, como por exemplo, martelo e prego, pá e solo. É através deste vínculo objetivo que se dá a relação das ferramentas com o homem e as atividades que desenvolve.

É importante salientar que para Dewey o uso de instrumentos implica a compreender a relação meio-conseqüência. Diz ele: “[...] um instrumento é uma coisa usada como meio para chegar a certas consequiências, ao invés de tomá-las direta ou fisicamente. É algo intrinsecamente relativo, antecipativo, previsível. Sem referência ao ausente, ou “transcendente” nada é um instrumento.” (Dewey, 1958, p.185)

Os animais estão privados de usar instrumentos e com isso não conseguem distinguir entre a existência direta e resultados potenciais, não dispõem de outras maneiras para projetar as consequiências de suas ações. Eles contam apenas com a estrutura corporal, geralmente fixa, para conseguir os resultados. Isto implica dizer também que o uso do instrumento traz 
em si uma distinção e uma identificação. Os acontecimentos se transformam em objetos, adquirem significação.

Desta forma, a invenção e uso de instrumentos corrobora com o processo de desenvolvimento e consolidação de significações, já que estas também são instrumentais, ou seja, são meios usados para chegar a certas conseqüências. A significação é a linguagem que tem como característica especial ser o "instrumento dos instrumentos" ou "a mãe amorosa de toda significação" (cf. Dewey, 1958, p. 186)

\subsection{Conceito como instrumento}

Dewey se contrapõe à filosofia clássica concebida à luz do ócio e que tem suas formulações baseadas na idéia de admiração e contemplação final. Ela se pauta por uma divisão na natureza em termos de uma física dialética: por um lado, os objetos finais das belas artes, o Ser pleno, ou seja, as coisas intrinsecamente perfeitas, permanentes e auto-suficientes, expressas numa lógica de conceitos imutáveis, que se prestam à contemplação e gozo das classes superiores ociosas e, por outro lado, os instrumentais ou operativos da indústria, necessários para atender à carência, falta, imperfeição - o não-ser, isto é, as coisas intrinsecamente deficientes, relativas e em mudança que, em termos sociais, corresponde à classe trabalhadora. A auto-suficiência da primeira classe se dá por conta da insuficiência da segunda. Este dualismo gerou outros como sensações e pensamento racional, particular e universal, mecânico e teleológico, experiência e ciência, matéria e mente. O contra-argumento de Dewey à metafísica, defendendo que as coisas se prestam a conexões operativas, é o seguinte: "As coisas têm potencialidades ou são instrumentais porque não são Ser, mas, especialmente, Ser em processo de devir. (Dewey, 1958, p. 123) A sua crítica social direciona-se à classe ociosa, que se e se apropriou e se beneficiou dos resultados acumulados das observações e procedimentos da classe trabalhadora (artesão, navegantes, construtores) para formular suas teorias, mas condenou a classe trabalhadora depreciando sua atividade.

Enquanto os pensadores condenaram a classe industrial e depreciaram o trabalho, eles apropriaram-se dos fatos e conceitos que deram forma e substância às suas próprias teorias. Pois, fora dos processos da arte não havia base alguma para introduzir a idéia de satisfação, realização no conceito de fim, nem para interpretar as operações antecedentes como potencialidades." (Dewey, 1958, p. 125)

Dewey reconhece que, em contrapartida, os pensadores gregos desenvolveram a idéia de ciência, algo além do que haviam alcançado o artista e artesão. A idéia de 
conhecimento ficou liberada de forma a constituir um ideal de investigação a partir das relações lógicas entre as coisas existentes. O pensamento adquiriu novo status: "Descobriu-se que o pensamento é uma empresa que tem seus próprios objetos e procedimentos; e a descoberta do pensamento como o método dos métodos em todas as artes, acrescentou uma nova dimensão à experiência subseqüente. (Dewey, 1958, p.125)

As artes instrumentais, artes de regulação que adotam como base o estudo da natureza multiplicam os objetos que satisfazem às necessidades, tornando-os bons e seguros. "os deuses retiram-se à penumbra. $\mathrm{O}$ culto se transforma em moral", considera Dewey.

As ciências nasceram das artes expressas no esforço de domínio e controle das coisas (ciência físicas), pessoas (ciências do espírito), de forma que as consequiências, resultados, desenlaces fossem mais seguros e estáveis. Isto ocorreu quando o homem começou a empregar ferramentas e instrumentos para manipular as coisas fazendo-as cooperar com a obtenção dos objetos desejados. As coisas em questão não foram tomadas em suas qualidades imediatas, ou como objetos com um status completo, mas destacam certas características que servem como sinais ou índices de outra coisa, ou seja, meios para regular possíveis resultados ulteriores. Esta idéia está implícita no conceito de significação:

O conceito mesmo de significação cognoscitiva, de sentido intelectual, é que as coisas são subordinadas, no que têm de imediato, àquilo que elas anunciam e que dão sinal. Um sinal intelectual denota que uma coisa não é tomada diretamente, mas é referida a algo que pode sobrevir como conseqüência dela. Significações intelectuais podem ser apropriadas, gozadas, estimadas por si mesmas, mas o caráter da significação intelectual é instrumental. Afortunados de nós que podemos gozar_diretamente os instrumentos e seus usos, porque, de outro modo, todo trabalho seria escravidão. Porém, este fato adicional não altera a definição de instrumento, que segue sendo uma coisa usada como agente para algum acontecimento definitivo. (Dewey, 1958, p. 128, itálico nosso)

Tomar os objetos de forma completa com significados imanentes impede de usá-los como indicação e implicação de outras coisas. Os fins qualitativos (cores, frio, úmido e seco, duro e brando, o leve e pesado, etc.) assimilam o conhecimento à contemplação estética. Para Dewey, há uma mudança radical na rota do pensamento com a nova concepção do método: “O resultado líquido do novo método científico foi o de conceber a natureza como um objeto mecânico-matemático.” (Dewey, 1958, p. 131) Tomar a existência como meio não significa que eles sejam opostos a sua posse e apreciação como fins, pelo contrário, torna-os mais seguros e estendidos. Tomar as coisas da existência como meio significa tomá-las na sua aparência, na forma como certas qualidades são dadas à percepção numa certa relação espaço- 
temporal. Entretanto, a percepção é limitada e não percebe as coisas na plenitude de suas conexões. Portanto, é necessário o desejo de tomar as coisas como sinais de fins ausentes, ou seja, uma nova relação é acrescentada de forma que uma coisa presente anuncia ou significa uma coisa ausente. Dewey coloca a questão da relação entre a aparência e a ausência, e não da aparência e essência, como faz a metafísica clássica. A diferença entre o aparente e o ausente prepara e constitui a inferência que necessita de um componente simbólico ou de um sistema: "Ligar as coisas que são tidas aparente e imediatamente com outras por meio do que não é imediato e aparente, criando, assim, novas sucessões históricas, com novos inícios e novos finais, depende, por sua vez, do sistema de sistemas mecânico-matemáticos, que formam os objetos próprios da ciência como tal. (Dewey, 1958, p. 138)

Daqui resulta a idéia de conhecimento, que é essencialmente a significação ou sentido. Conforme se referir a um objeto, idéia ou verdade o sentido assume diferentes nuances: se relacionado a um objeto, seu sentido será a totalidade de respostas práticas que ele produz em nós - uma cadeira será a totalidade de usos e hábitos que ela nos sugere; se relacionado a uma idéia, o significado designa um plano de ação, uma série de mudanças que serão produzidas entre as coisas; se relacionado a uma verdade, expressa o valor ou importância. (Cf. Dewey, 1953, p. 246)

Dewey adverte que o giro subjetivista do pensamento moderno poderá criticar a teoria "instrumental" do conhecimento, por entender que o valor do conhecimento é instrumental para o sujeito que conhece. A defesa do instrumentalismo é colocada da seguinte forma: "é uma teoria não sobre a disposição e satisfação pessoal em conhecer, mas sobre os objetos próprios da ciência, onde 'próprio`é definido em termos de física. (Dewey, 1958, p. 151) Instrumento pode ser distinguido de produto, explicando a distinção entre objetos conhecidos e objetos de apreciação e afeição, mas a distinção é primeiramente sobre objetos e só secundariamente às atitudes e motivações. O caráter de objetos e instrumentos é o mesmo: "é uma ordem de determinação de mudanças sucessivas que terminam em uma conseqüência prevista." (Dewey, 1958, p. 151)

Dewey estabelece as diferenças entre o método da ciência antiga e da ciência moderna: naquela, a essência é a demonstração, nesta, o sangue é a descoberta; a reflexão da ciência antiga visa alcançar um objeto estável; enquanto na moderna o conhecimento "existe na prática, para o fim de estimular, dirigir e comprovar ulteriores investigações." (Dewey, 1958, p. 152) Ele recorre à afirmação que considera revolucionária de Leonardo, como um anúncio da ciência moderna ao dizer que o verdadeiro conhecimento começa pela opinião. A 
opinião figura assim como uma espécie de aventura, instiga novas investigações, é ponto de partida, sendo indispensável para o conhecimento deliberado.

O autor que estamos estudando enfatiza a importância do que já é conhecido para ciência: "O já conhecido, o que é aceito como verdade, é de imensa importância; sem ele a investigação não poderia sequer dar um passo.” (Dewey, 1958, p. 154) Entretanto, é necessário compreender o lugar que cabe ao já conhecido que é o de ser objeto hipotético a ser usado, tendo que se ajustar aos descobrimentos que torna possível. Afirma Dewey: "Quando as coisas são definidas como instrumentos, seu valor e validade reside no que procede delas; as consequiências e não os antecedentes fornecem significação e verdade. As verdades já possuídas podem ter uma certeza prática ou moral, mas logicamente nunca perdem certa qualidade de hipotéticas.” (Dewey, 1958, p. 154) E Dewey coloca a condição para ser verdade e indica o a fórmula do método: "São verdades se: se outras certas coisas eventualmente se apresentarem; e, quando estas últimas coisas ocorrerem, elas sugerem, a sua vez, ulteriores possibilidades; a operação da dúvida-investigação-descoberta repete-se. (Dewey, 1958, p. 155, itálicos nossos). Portanto, verdade guarda estreita relação com uma significação que satisfaz da melhor forma um determinado processo de dúvida-investigação.

Dewey mostra o como certas teorias idealistas do conhecimento acabam desviando a compreensão do pensamento na investigação. Se por um lado são compreensivas em relação ao método e objeto da ciência, consentindo que o objeto do conhecimento seja o objeto encontrado mais do que o dado, toma a função instrumental da inteligência num sentido global e absoluta e não como detalhe e relativa. Diz Dewey:

[...] tomou a re-constituição por constituição, a re-construção por construção. (...) o resultado foi converter uma função de transformação em um ato de criação original e final. [...] Em suma, o idealismo é culpado de não ter advertido que o pensamento e o conhecimento são histórias. (Dewey, 1958, p. 158)

Para ele, a mudança e a reconstrução dos objetos somente podem ocorrer através da ação e transformação. Indica a função do pensamento como condição da ciência:

Pensamento`, razão, inteligência, qualquer palavra que escolhamos usar, é existencialmente um adjetivo, ou melhor, um advérbio, não um substantivo. É uma disposição à atividade, uma qualidade desta conduta que prevê as consequiências dos acontecimentos existentes e que usa do previsto, como um plano e um método de administrar coisas. (Dewey, 1958, p. 158/9)

A teoria do pensamento que Dewey desenvolveu é uma teoria sobre a natureza como um processo interativo. A natureza é um continuo devir, fluxo, mudanças, história, uma 
ininterrupta sucessão de movimentos. A mente, ao refletir, vê pontos de interrupção e, por meio da abstração, dá uma estabilidade ideal, mesmo considerando que em sua manifestação natural está em contínuo fluxo. Pensar significa fixar, abstrair, definir, dar consistência, permanência e unidade inteligível às idéias e propósitos. Conceber e regular a experiência depende do movimento dialético entre estes dois opostos: mudança e permanência.

Para compreender melhor este complexo movimento que constitui a natureza, citamos a definição elaborada por Dewey, focando três características que, nesta circunstância, sintetizam a nossa discussão sobre este conceito:

Em primeiro lugar se admite que alguns acontecimentos naturais são finais, quer sejam gozados, quer detestados; são acontecimentos que ocorrem sem que se tenha controle sobre eles, prescindindo da escolha reflexiva e da arte, que só casualmente ocorrem. Em segundo lugar, implica que os acontecimentos, sendo acontecimentos, e não substâncias rígidas e maciças, estão sempre em marcha e, portanto, como tais inacabados, incompletos e indeterminados. Conseqüentemente possuem a possibilidade de serem pilotados e governados de forma que os fins podem ser satisfação e não simplesmente términos, conclusões e não simplesmente fechamentos. A suspensão, dúvida, hipóteses, experimento, com suas alternativas, são expoentes destas fases da natureza. Em terceiro lugar, a regulação de processos em marcha e incompletos, em busca de conseqüências escolhidas, implica que existem ordens de seqüência e coexistências envolvidas; estas ordens ou relações, quando clarificadas, são meios intelectuais que nos capacitam para usar os acontecimentos como meios concretos de dirigir o curso das coisas para prever conclusões. (Dewey, p.1958, 159)

Para Dewey, tanto o materialismo como o idealismo tradicional classificam estas ordens de relações como sendo os únicos objetos "reais", resultando num universo encaixado e completo. Negam o fato de estas relações estarem em contínuo movimento caracterizado por começos e fins que se distinguem em individualidades instáveis. Tomam a natureza de forma acabada, cabendo à mente um lugar sobrenatural ou extra natural. Contra-argumenta Dewey, defendendo a qualidade temporal da existência natural, individualizada e plural, mas também recorrente ou uniforme. A ciência é possível na medida em que, apoderando-se das uniformidades, torna as mudanças rítmicas e previsíveis: "Sem uniformidades a ciência seria impossível. Mas se elas existissem sozinhas o pensamento e o conhecimento seriam impossíveis ou sem sentido. [...] os objetos últimos da ciência são processos de mudança dirigidos." (Dewey, 1958, p. 160)

O filósofo pragmatista desta pesquisa considera necessário estender o uso da palavra verdade para além do sentido restrito de "propriedade lógica das proposições", para a referência existencial designando o caráter desta. Assim, verdade tem o seguinte sentido: 
"processos de mudança dirigidos de tal forma que alcancem uma realização intencionada." (p. 161) Ela é instrumental no sentido de que uma operação está se processando, um fim em vista está em processo de atualização, ou um meio que só atua como meio no seu fim. Acrescenta Dewey: "Assim, pode-se dizer de forma inteligível e não como simples tautologia, que o fim da ciência é o conhecimento, subentendendo que conhecimento é mais que a ciência, é seu fruto.” (Dewey, 1958, p. 161) Conhecimento significa, para Dewey, que "acontecimentos entendidos, acontecimentos penetrados tão discriminativamente pelo pensamento que a mente está, literalmente, em sua casa com eles. Significa compreensão, ou inclusive acordo razoável.” (Dewey, 1958, p. 161)

Há uma sintonia para este autor entre a ciência, o conhecimento, a natureza e o homem: "Somente quando se vê a realização autêntica da ciência na administração inteligente dos processos históricos dentro de sua continuidade, pode o homem ser visualizado dentro da natureza e não como algo sobrenatural extrapolado." (Dewey, 1958, p. 163)

\subsection{Conceito e organismo: crítica ao dualismo mente corpo}

Na obra em análise - Experiência e Natureza - Dewey desenvolve o problema da relação da mente / espírito com a natureza em geral e do corpo orgânico, em particular, em diversas experiências culturais. Ele argumenta que este problema teve soluções divergentes em cada uma das diversas experiências culturais, com suas filosofias correspondentes, mas todas incorreram no mesmo erro metafísico do dualismo espírito e corpo. Para os gregos, a vida era concebida de forma psíquica, era automovimento, cuja prova se tem diretamente pela percepção. Os seres vivos, plantas ou animais, são dotados naturalmente de alma. O pensamento grego trata com atenção piedosa o corpo humano, como se vê na religião, escultura e jogos, pois ele é a realização máxima das possibilidades físicas da natureza e possibilidade do espírito. A natureza é concebida de forma mecânica, cíclica e as contingências da vida e a morte do corpo não são um problema, uma vez que o espírito criado se funde, mais tarde, às forças que o originaram. Seus pensadores estavam dominados pelas características estéticas dos objetos da experiência. A cultura grega era marcadamente estética. Os trabalhos de arte têm a característica de todos qualitativos completos e acabados: "A medida, os limites fixos, razão e proporções fixas são sinais de tudo o que verdadeiramente é. Tais objetos ou sujeitos, são substâncias que possuem fim e forma em um sentido objetivo." (Dewey, 1960, p. 84) A filosofia foi construída com uma pauta artística inspirando admiração e maravilhamento. A filosofia grega, diz Dewey, "era ciência, uma 
contemplação das realidades situadas atrás de todas as cópias, todos os fenômenos; ou um captar as essências constitutivas dentro das quais se forma a substância verdadeira." (Dewey, 1958, p. 88). Portanto, a filosofia incorpora as características de forma e finalidade, ordem e proporção, próprios da arte, fazendo com que a mudança seja detida num objeto privilegiado, “objeto de gozo direto hipostasiados numa realidade transcendente." (cf. Dewey, 1958, p. 90). A mudança está incluída dentro de limites fixos a partir dos quais pode ser conhecida. No caso de Aristóteles, a metafísica é uma "ciência da realidade última e eterna, a que são atribuídos somente predicados estáticos." (Dewey, 1958, p. 91). A concepção aristotélica ${ }^{15}$ das quatro causas é tomada das artes. Úteis e domésticas para o artesão, elas se tornam belas ou liberais, observa Dewey, "para um expectador cultivado que está em possessão do ócio, isto é, está relevado da necessidade de tomar parte com seu trabalho na mudança e na matéria. (Dewey, 1958, p. 9). Neste caso, Aristóteles coloca a natureza como o artista que opera por dentro sem necessitar da ação externa. Os modelos estão dados objetivamente, tratando apenas de observar, seguir, comemorar. Neste sentido Dewey salienta o foco da filosofia grega: "a reflexão grega, levada a cabo por uma classe ociosa interessada no ócio liberador, foi proeminentemente a do expectador, não do partícipe no processo de produção.” (Dewey, 1958, p. 90). O mesmo aconteceu com o aspecto da moral grega que se converteu numa metafísica e ciência do Ser, concebendo o bem supremo esteticamente.

$\mathrm{Na}$ experiência do cristianismo, o corpo é concebido como terreno, carnal, concupiscente, passional, tratado como a fonte do pecado e carregado de todas as propriedades da matéria: é múltiplo, está sujeito às mudanças e à dissolução. Já o espírito é como Deus, incorruptível, eterno, uno, indissolúvel. A metafísica platônica e aristotélica da desvalorização da matéria culminou numa desvalorização moral e essencial da própria matéria, no cristianismo. O problema é que matéria e espírito, mesmo sendo duas coisas contrárias, encontram-se unidas no corpo. A solução encontrada foi a defesa do temor moral à carne e o interesse por ressuscitar em outro mundo, onde se terá como recompensa a felicidade ou o tormento eterno. Desta forma se dá a antítese espírito e matéria.

A metafísica aristotélica persistiu na cultura ocidental, e o corpo ocupou uma posição intermediária: é o termo mais alto de uma série física e o mais baixo de uma série psíquica,

\footnotetext{
15 A dimensão da causalidade é explicada por Aristóteles através da teoria das quatro causas que são as seguintes: 1. Causa Formal; 2. Causa material; 3. Causa Eficiente e 4, Causa Final. (Física II, 3, 194b16)
} 
possibilitando, assim a manifestação das realidades ideais. No pensamento medieval não havia problemas na relação do espírito com o corpo, uma vez que estava justificado pela metafísica aristotélica. Porém, a explicação metafísica clássica do possível e do real entrou em questionamento a partir do momento em que se deixou de interpretar e explicar os fatos em termos de potência e ato e se recorreu à causalidade. Essa nova concepção não encontrou mais intermediários entre corpo e espírito. Entretanto, mesmo com bases teóricas divergentes, acabou servindo-se do pensamento clássico e medieval para formular e justificar a nova concepção. Assim, a distinção entre alma vegetativa, animal e racional que justificava a divisão de classes na sociedade grega entre escravos e artesãos (corpo vegetativo com impulsos contra a razão), o bom cidadão (alma sujeitável à razão / pensamento) e os cientistas e filósofos (pura razão), deu base para o pensamento helenístico criar uma tríplice distinção entre corpo, alma e espírito, dando a este último poder sobre todas as coisas e o domínio das coisas espirituais e religiosas. Aboliu assim a separação, sustentada para fins morais e práticos pelo cristianismo, entre carne e espírito, pecado e salvação, rebelião e obediência. Por outro lado, preparou um rico terreno empírico para a concepção dualista do cartesianismo formalista, o materialismo de Hobbes e uma variedade de outras concepções.

Para Dewey, a dificuldade não está na diversidade de soluções ao problema, mas encontra-se nas teses metafísicas subjacentes que determinam a formulação do problema, ancoradas na relação dualista espírito e corpo. Para ele, a base do problema é a seguinte: "a negação da qualidade em geral dos acontecimentos naturais; a ignorância em particular da qualidade temporal; e o dogma da realidade superior das causas." (Dewey, 1958, p. 252). A partir desta constatação Dewey desenvolverá a sua tese empírica, de base biológica, que apresentaremos a seguir.

\subsection{Conceitos na concepção naturalista: continuidade e interação entre meio e organismo}

A tese empírica que Dewey desenvolve assume como responsabilidade a tarefa de explicar como o lógico se conecta com o biológico, num processo de desenvolvimento contínuo. A natureza da pauta da investigação baseia-se no desenvolvimento de aspectos da pauta das atividades vitais. A observação de Dewey a este respeito é a seguinte:

Se o que se designa pelos termos como dúvida, crença, idéia, concepção tem algum sentido objetivo, sem se falar nada sobre a verificabilidade pública, 
terá que ser localizada e descrita como uma conduta na qual o organismo e o meio atuam conjuntamente ou inter-atuam. (Dewey, 1960 p. 33).

A tese deweyana parte de uma distinção biológica entre seres vivos e não vivos (inanimados). Esta distinção não pode ser entendida como uma ruptura entre ambos, nem uma redução de um ao outro. Trata-se de um postulado da teoria naturalista deweyana, que expressa a continuidade entre as formas inferiores (menos complexas) e as formas superiores (mais complexas) (cf. Dewey, 1960 p. 23). Desta forma somos convidados a estudar a matriz do comportamento vital desenvolvida por Dewey.

Os seres vivos desempenham atividades de conservação pela renovação: "um ser vivo é aquele que domina e regula em benefício de sua atividade incessante as energias, que de outro modo o destruiriam. A vida é um processo que renova a si mesmo por intermédio da ação sobre o meio ambiente" (Dewey, 1979b, pg. 2). A atividade que caracteriza a vida orgânica supõe a existência de um ambiente. Diz Dewey: "um organismo não vive em um meio, vive em virtude de um meio circundante" (Dewey, 1960, p. 25, itálico do autor) O ambiente é a única fonte de onde os organismos retiram as energias gastas para manter seu funcionamento orgânico enquanto seres vivos. A função orgânica se realiza na interação de energias entre o intra-orgânico e o extra-orgânico. Pode ocorrer de forma direta como na ingestão de alimentos ou indireta como na circulação de sangue. $\mathrm{O}$ organismo vivo utiliza as energias que o cercam (luz, ar, água, matérias do solo, etc.), transformando-as em meios para sua conservação. Se existir suficiente reposição da energia de forma a estabelecer um balanço entre as demandas do organismo e o meio, o organismo cresce, caso contrário, começa a degeneração. A continuidade da vida só é possível pela readaptação constante do ambiente às necessidades do organismo. Embora haja continuidade relativa da vida em um organismo (indivíduo), pois este fenece, o processo da vida é contínuo pela reprodução de outras formas de vida cada vez mais complexas. Com a diferenciação da estrutura dos organismos, ocorre a expansão do ambiente. Um novo órgão procura estabelecer um novo modo de interação com o ambiente, transformando parte do mundo, que lhe era indiferente, em função vital. A diversidade de interações impõe a necessidade de equilíbrio entre elas, o que Dewey chama de "ambiente unificado": "O equilíbrio tem de ser mantido por um mecanismo que responda às variações que ocorrem dentro do organismo e às que ocorrem em seu meio.” (Dewey, 1960 p. 26)

As atividades de conservação dos organismos apresentam as seguintes características: necessidades, esforço, que são demandas ativas para satisfazer as 
necessidades, e satisfação. (Dewey, 1958, p. 208) Vale a pena compreender cada um desses conceitos empregados por Dewey.

Por necessidade se entende um estado tenso de distribuição das energias tal que o corpo se encontra em uma condição de desconforto e equilíbrio instável. Por demanda ou esforço se entende o fato que este estado se manifesta em movimentos que modificam os corpos do ambiente em formas que reagem sobre o corpo, de tal sorte que restabelece seu padrão característico de equilíbrio ativo. Por satisfação se entende esta recuperação do padrão de equilíbrio, resultado das mudanças sobre o ambiente devido às interações com a demanda ativa do organismo. (Dewey, 1958, p. 253)

O exemplo que Dewey cita é o da planta com suas necessidades de água, bióxido de carbono, sol, sua necessidade de produzir sementes. Mas, a necessidade em si, enquanto um estado concreto de acontecimentos, não distingue a atividade de uma planta da atividade físico-química de corpos inanimados, como o ferro, por exemplo. Estes também estão sujeitos às perturbações de seu equilíbrio interno na relação com as coisas circundantes, que terminam em ciclos de mudanças. Onde está a diferença entre as atividades de ambos? Dewey argumenta que os seres animados não têm algo adicional à energia físico-química que é comum também para os seres inanimados, entretanto, os seres animados reagem criando maneiras de se interconectar e operar com essas energias, resultando em diferentes consequiências para a atividade de cada uma. Nos seres vivos, a atividade reativa restabelece o padrão de equilíbrio de seu processo de forma a prolongar a atividade caracteristicamente organizada. Esta passará a contar com um acréscimo originado da conservação das atividades passadas e que permitirá adaptar as mudanças seguintes às necessidades do sistema integral a que eles pertencem. Há o restabelecimento do padrão, ou da forma de relação ou de interação, mas não em condições idênticas. (cf. Dewey, 1958, p. 254). O processo necessidadesatisfação instaura um movimento de mudanças, que geram novas necessidades, numa cadeia ilimitada. São processos automantenedores do equilíbrio, provendo um ambiente unificado. Organismos complexos têm mais dificuldade para manter o equilíbrio: "Quanto maior for a diferenciação das estruturas e de suas atividades correspondentes, maior é a dificuldade para manter o equilíbrio. Pode-se considerar o viver como um ritmo contínuo de desequilíbrios e recuperação de equilíbrios.” (Dewey, 1960 p. 26) O restabelecimento do equilíbrio significa que organismo e ambiente forma complexos modificados. Embora persistam as necessidades como, por exemplo, a fome, elas não ocorrem em condições idênticas, alterando-se sua qualidade e consequentemente a nova satisfação. E, assim temos uma cadeia de necessidade satisfação - mudanças ilimitada. Este processo Dewey chama de evolução orgânica: "A capacidade de construir e conservar formas modificadas de adaptação em resposta a 
condições novas é a fonte daquele desenvolvimento mais extensivo chamado evolução orgânica." (Dewey, 1960, p. 28)

Por outro lado, o processo que ocorre nos corpos inanimados é chamado de saturação. (Cf. Dewey, 1958, p. 209) Nestes seres, por exemplo, o ferro, a saturação ocorre indiferentemente, eles não apresentam tendência de modificar a interação para manter seu padrão de atividades de forma a perpetuar suas características próprias, como ocorre em um organismo. O ferro, assim como todos os seres deste nível, não age como um organismo, pois não busca manter uma relação estável com o meio.

Para designar a atividade específica dos organismos enquanto tais, Dewey escolheu o termo psico-físico, evitando assim a identificação popular do físico com o inanimado. Ele explica o entendimento do termo "psico-físico":

[...] denota a presença conjunta em uma atividade da necessidade, do esforço e da satisfação [...] denota que a atividade física adquiriu propriedades adicionais, a aptidão para obter dos meios circundantes uma classe peculiar de satisfação interativa das necessidades; não denota uma abolição do físicoquímico, nem uma estranha mescla de algo físico e algo psíquico [...]; denota a posse de certas qualidades e eficiências que não se mostram no inanimado. (Dewey, 1958, p. 255)

E quais são essas propriedades adicionais, as qualidades e a eficiência que os organismos possuem? Nesta análise dos acontecimentos empíricos, Dewey identifica algumas qualidades e eficiências distintas. A organização é a primeira de todas. Ele afirma: “Organização é um fato, porém não é uma força organizadora original” (Dewey, 1958, p. 254) A organização precisa ser investigada nas condições reais em que se dá, nas suas modalidades e conseqüências, e não por construções conceituais prévias. Ela afeta toda investigação de atos altamente complexos. Da idéia de organização, Dewey depreende a idéia de sensibilidade. Diz ele: "sempre que as atividades das partes constitutivas de um padrão organizado de atividades são de tal natureza que conduzem a perpetuar a atividade padrão, existe a base da sensibilidade.” (Dewey, 1958, p. 256) E continua o seu argumento:

[...] a presença geral e operante do todo na parte e da parte no todo constitui a susceptibilidade - a capacidade de sentir - quer esta potencialidade se realize ou não na vida da planta. As respostas não são simplesmente seletivas, mas são discriminadoras em favor de certos resultados melhores que outros. Esta discriminação é a essência da sensibilidade. Assim, com a organização, a tendência passa a ser interesse e a satisfação um bem ou um valor e não meramente a saciedade das vontades ou a repleta deficiência. (Dewey, 1958, p. 256)

Dewey amplia essa análise para organismos com capacidade de movimento. Nos 
organismos inferiores acontece um contato direto no processo interativo entre energias orgânicas e energias do ambiente. Há uma tensão entre superfície-interior no processo de satisfação. Os organismos superiores estão dotados de receptores à distância como a vista, ouvido e em menor grau o olfato e de órgãos de locomoção que lhes permite conectar-se tanto com o próximo, quanto com o remoto. Por isso, desenvolvem atividades de contato direto e atividades de interação à distância ${ }^{16}$ ou indiretas. As primeiras são chamadas de realizadoras ou consumadoras. As segundas, por envolver resposta ao que está distante, caracterizam-se por uma expectativa ou predição de contatos posteriores, sendo preparatória ou antecipativa. Há um intervalo de tempo maior entre a necessidade e a satisfação. O comportamento tem, portanto, um caráter de seqüencialidade, com uma ordem definida de atividades iniciais, intermediárias e finais. Desta diferenciação de atividades preparatórias e consumatórias resulta uma "tensão" porque elas não se encontram de acordo. Cada resposta preparatória está tomada pela matriz da atividade sexual, nutritiva e de segurança para a qual contribuem. Assim, a sensibilidade, enquanto capacidade, é atualizada como sentido. Ao criar suscetibilidade para o útil ou o nocivo no ambiente, cria-se uma premunição, motivos para eventuais consequiências na vida. É importante destacar que na percepção animal, por meio dos órgãos dos sentidos, não ocorre um isolamento entre o que é percebido em relação ao curso do comportamento vital. Não há uma suposta diferenciação sujeito-objeto o que poderia obstaculizar ou mesmo ser fatal para o animal.

A consumação de uma atividade ou satisfação de uma necessidade apresenta outra característica importante, que é a continuidade na forma de acompanhamento e reforço das atividades preparatórias ou antecipativas. A consumação de uma atividade traz também acumulação, integração e conservação. Nesse processo, o sentido pode receber e sustentar distinções sem fim através da multiplicação e da variação:

Com a multiplicação das reações sensíveis discriminatórias para as diferentes energias do ambiente (diferenciação dos órgãos dos sentidos, extra-ceptores e intra-ceptores) e com o aumento do alcance e delicadeza dos movimentos (desenvolvimento dos órgãos motores a que correspondem órgãos glandulares internos para efetuar a requerida distribuição de energia), vão variando mais e mais os sentidos em qualidade e intensidade. (Dewey, $1958,257 / 258)$

\footnotetext{
${ }^{16}$ Os diversos modos de interação entre organismo e ambiente podem ser compreendidos também pelos termos excitação-reação e estímulo respostas. "O estímulo não é outra coisa senão a parte primeira de todo o comportamento serial coordenado e a resposta a última parte. (Dewey, 1960, p. 30)
} 
Dewey salienta que a capacidade de sentir dos animais complexos e ativos varia abundantemente em termos de qualidade em função das relações que mantém com o ambiente. A diversidade de sentidos ocorre em função das direções e fases em que acontecem suas atividades diretamente ligadas com o ambiente: iniciação, mediação, satisfação ou frustração. Entretanto, os animais não sabem que os têm, pois sua atividade é psico-física e não mental. Não tem consciência dos significados.

\subsection{A origem da significação e da mente}

A partir dessas distinções, Dewey desenvolve a análise da origem das significações e da mente nos organismos superiores. Nestes organismos, as atividades interativas entre organismo e meio se diferenciam e se tornam complexas desenvolvendo-se ilimitadamente. Assim, nestes organismos as atividades psico-físicas ganham novas estruturas, na medida em que as interações ocorrem de forma compartilhada com os outros membros da espécie. Desta maneira, as qualidades dos sentimentos passam a ser diferenciadas e significadas com o uso da linguagem, dando origem à mente. A formulação deweyana do conceito de mente é a seguinte:

Assim como a vida é uma qualidade de acontecimentos num estado peculiar
de organização, e "sentido" é uma qualidade das formas de vida marcadas
(caracterizada) por respostas discriminativas e complexamente móveis, da
mesma forma, a "mente" é uma propriedade adicional assumida por uma
criatura que sente, quando alcança essa interação organizada com outras
criaturas vivas, que é linguagem, comunicação. Então, as qualidades do
sentido passam a ser os significados das diferenças objetivas nas coisas
externas dos episódios passados ou por vir. Este estado de coisas no qual os
sentidos qualitativamente diferentes não são somente tidos, mas são
significados das diferenças objetivas, é a mente. Os sentidos já não são mais
apenas sentidos (sensações). Eles têm e fazem a compreensão, recordam e
profetizam. (Dewey, 1958, p. 258; aspas e itálico do autor)

Os sentidos ${ }^{17}$ empregados como indicação de atos realizados ou a realizar, ou como sinal das conseqüências destes, constituem os significados. Quando são sentidos imediatos de

\footnotetext{
${ }^{17}$ Dewey faz ainda o seguinte comentário sobre esse conceito: "Sentido é, em geral, um nome para a qualidade recém realizada e adquirida por acontecimentos previamente ocorridos ante a certo nível físico, quando estes acontecimentos entram em relações de interação mais amplas e delicadas. Mais especificamente, é um nome para a vinda à existência destas diferenças últimas dos atos em questão que distingue um dos outros e dá a eles distinção. Diferenças que sobre o plano físico só podem ser ditas antecipando uma realização posterior, ou em termos de diferentes fórmulas matemáticas e diferentes posições e contigüidades no espaço-tempo" (Dewey, 1958, p. 267).
} 
fatos ou objetos são sensações (sensa). Sem o uso da linguagem são sensações de dor, prazer, calor, barulho, cheiro, etc., apenas potenciais. O uso da linguagem permite discriminar e identificar essas qualidades, objetificá-las como traços característicos imediatos das coisas. Quando se insere o sentir, ou seja, uma qualidade de relação ativa entre organismo e meio, através da linguagem num sistema de sinais, essa qualidade aparece como uma demanda do organismo a um objeto extra-orgânico. Assim, por exemplo, dar o nome a uma qualidade de fome, é fazer referência a um objeto que a satisfaz e em torno dela a situação ativa se move.

Dewey insiste na idéia de que essas qualidades ${ }^{\mathbf{1 8}}$ resultam da interação em que participam os organismos e as coisas extra-orgânicas: não saltam milagrosamente do organismo ou da alma para o mundo exterior, nem do psíquico ao físico. Nomear estas qualidades permite a identificação e a discriminação das coisas que participarão como meio no curso futuro de interações. A crítica deweyana dirige-se à noção de conhecimento que afirma que as afecções sensoriais se diferenciam e identificam a si mesmas como sendo calor, sons, etc. e constituem certas formas elementares de conhecimento, sem o uso do discurso, da linguagem. Esta noção é absurda, parte de idéias pré-concebidas a respeito do espírito e conhecimento. Enfatiza: "a sensibilidade em si mesma é anoética; ela existe como qualquer qualidade imediata existe, mas, contudo, ela é um meio indispensável de toda função noética." (Dewey, 1958, p. 259)

Dewey menciona o próprio desenvolvimento mental de uma criança, para mostrar que as qualidades organicamente condicionadas, incluindo aquelas especiais dos órgãos dos sentidos (órgãos intra-ceptores), são discriminadas somente quando são empregadas para designar os objetos, como por exemplo, o vermelho como propriedade de um brinquedo, vestimenta, etc. Como essas qualidades se fundem com uma situação geral, elas são muito difíceis de serem identificadas. É na comunicação, no uso da linguagem como meio compartilhado de chegar a conseqüências sociais ou fins comuns que estas qualidades

\footnotetext{
18 As qualidades resultam de situações psico-físicas, em que a sensibilidade animal é incitada a reagir de determinado modo diante dos acontecimentos em nível físico. Diz Dewey, "as qualidades têm um poder seletivo e mantenedor de certa ordem de organização energética” (Dewey, 1958, p. 221) Elas não podem ser conhecidas no nível físico, mas gerando efeitos sobre as coisas vivas, estas reagem usando as qualidades como meios para produzir efeitos que são consequiências. Desta forma, os atos de utilização e adaptação formam uma série em que alguns atos preparam e outros consumam fazendo com que estas qualidades tornem-se inteligíveis, conhecidas através da linguagem. "Esta série forma o material direto do pensamento quando sobrevêm a comunicação social e o discurso.” (Dewey, 1958, p. 222)
} 
atingem nitidez. Assim, a criança terá que aprender através da convivência social o sinal que certas qualidades das ações significam e designam tais como gula, raiva, medo, etc.

Partindo do princípio de que as qualidades das situações interativas entre organismo e condições circundantes (sensações) fazem sentido quando discriminadas através de sinais, Dewey distingue os termos sentido e significação e confirma a dependência dessa relação para a existência da mente:

$\mathrm{O}$ ato de compreender (make sense) é distinto de sentido (feeling), pois ele tem uma referência reconhecida; é uma característica qualitativa de algo, não simplesmente uma qualidade ou tonalidade submersa não identificada. Compreender é diferente de significação (signification). Esta envolve o uso de uma qualidade como sinal (sign) ou índice de uma outra coisa, como quando o vermelho de uma luz significa perigo e a necessidade de parar o veículo em marcha. O sentido (sense) de uma coisa, por outro lado, é uma significação (meaning) direta e imanente, é uma significação que é sentida ou tida diretamente. [...] Sempre que uma situação tem essas duas funções de significação (meaning), a saber, a de significação (signification) e de sentido (sense), está definitivamente presente a mente, o intelecto. (Dewey, 1958, p. 261)

Estas distinções feitas correspondem à distinção entre o físico, psico-físico, e o mental, ou seja, entre o sentimento, o sentido e a significação. Constituem níveis crescentes de complexidade, que se estruturam mantendo íntima interação entre acontecimentos naturais. ${ }^{19}$ Dewey vê a inteligência como tendo origem biológica e amplamente distribuída entre as espécies. A inteligência dos animais inferiores e do homem difere em termos de grau e não propriamente em termos de gênero. Portanto, em termos biológicos, não existe base alguma que justifique conceber o homem como pertencente a um mundo distinto da estrutura da evolução.

Com esta formulação, Dewey considera um erro filosófico, uma falácia, a idéia de considerar a matéria, a vida e o espírito gêneros distintos do Ser, porque converte funções em substâncias, as conseqüências das interações dos acontecimentos, em causas da produção dessas conseqüências, reduplicando-as e confundindo a compreensão delas, enfim, dá

\footnotetext{
${ }^{19}$ Dewey sintetiza da seguinte forma estes três níveis dos fatos empíricos: "O primeiro, o cenário de interações mais estreitas e externas que, qualitativamente diversificado em seu interior, é física; suas propriedades distintivas são as do sistema mecânico-matemático descoberto pela física e que define a matéria como um caráter geral. O segundo nível, é a da vida. As diferenças qualitativas, como as existem entre a planta e o animal, formas animais inferiores e superiores, são aqui as mais notáveis, mas, apesar de sua variedade têm qualidades comuns que definem o psico-físico. O terceiro plano é a da associação, comunicação e participação. (Dewey, 1958, p. 272)
} 
denotação de existência à matéria (ao físico) e de essência à mente. Dewey entende a matéria conforme o tratamento que é dado na ciência, ou seja, ela é "uma propriedade dos acontecimentos quando eles ocorrem em certo nível de interação" (Dewey, 1958, p. 262), portanto, mais do que pura essência. A objeção deweyana dirige-se também ao materialismo e à metafísica mecanicista, doutrinas que concebem a matéria como causa eficiente da vida e do espírito e atribuem à causa uma posição superior ao efeito. Em relação a estas concepções, os fatos mostram o contrário. Ao introduzir a concepção de causalidade, deve-se considerar que são os acontecimentos naturais que têm caráter de matéria e são a causa da vida e do espírito e não a matéria em si. Os efeitos, contrapõe Dewey, "indicam o desatar-se das possibilidades, são manifestações mais adequadas da natureza do que simplesmente as "causas". (Dewey, 1958, p. 262). A vida, o sentimento e o mental estão numa dependência prática ou instrumental da matéria. É em virtude das propriedades desses acontecimentos que as questões do psico-físico e do intelectual podem ser determinadas em suas diferenças. Assim, o domínio dos acontecimentos mais complexos, amplos e profundos implica em analisar campos de interação e dependência mais elementares, próximos e menores. As descobertas acrescentam algo aos nossos recursos permitindo manejar os campos de interação mais próximos pois, desta forma, pode-se dirigir a produção dos mais complexos. Conclui Dewey: "Se não houvesse na vida e no espírito mecanismo algum, educação, modificações deliberadas, retificação, prevenção e controle construtivo seriam impossíveis.” (Dewey, 1958, p. 263)

Assim, Dewey faz a revisão das bases que deram origem ao problema do dualismo espírito e corpo. A revolução da ciência do século XVII introduziu um novo procedimento de abordagem da natureza:

[...] uma ciência frutífera da natureza começou somente quando os investigadores abandonaram as qualidades imediatas, os "sentidos" ("sensa") dos acontecimentos, úmido e seco, quente e frio, leve e pesado, acima e abaixo, pelas qualidades "primárias", a saber, significativas, e quando trataram estas últimas, ainda que chamadas qualidades, não como tais, mas como relações. (Dewey, 1958, p. 217)

Enquanto a ciência clássica adotava o procedimento de tratar dialeticamente os fenômenos qualitativos dos sentidos e dos costumes, tomando as qualidades diretas sensoriais e significativas dos acontecimentos como forma de classificar e compreender, a nova ciência, 
ao tomar as relações dos acontecimentos como objetos próprios do conhecimento, usa de uma nova dialética, que é a da substituição pelas equações e funções matemáticas, para conduzir a novas relações e generalizações ${ }^{20}$. Os fenômenos psicofísicos e espirituais são tomados na realidade empírica, abandonando-se o dualismo gerador da ruptura, na continuidade do processo histórico.

Tal dualismo promove a fragmentação da continuidade das mudanças históricas em duas partes separadas e a criação de falsos procedimentos para uni-las, como se pode ver, por exemplo, nos conceitos de infância e fase madura. Em uma teoria, a infância é vista como uma viagem insignificante para a fase adulta; em outra, a idade adulta é projeção da infância, de um estado pré-natal, da herança ou de um antecedente fixo e separado. Dewey defende que o ser humano encontra-se em constante processo de crescimento que mantém estreita relação com o desenvolvimento social da sociedade: A existência real é a história em sua totalidade, a história tal como ela é. As
operações de dividi-la em duas partes e então ter que uni-las de novo
recorrendo às forças causantes são arbitrárias e gratuitas. A infância é a
infância de e em um certo processo consecutivo de mudança, que é
exatamente o que ele é, e o mesmo é a maturidade. Dar às propriedades
distintas de cada fase uma espécie de existência independente e utilizar logo
a forma selecionada para que explique ou responda ao resto do processo, é
uma repetição tola; é repetição porque, depois de tudo, não temos senão
partes da mesma história original; e tola, porque nos iludimos com uma
explicação para a história baseados numa seleção arbitrária de uma de suas
partes. (Dewey, 1958, p. 275 , itálicos do autor)

\subsection{Conceitos e hábitos}

No estudo da relação do organismo e meio, Dewey analisa o ato de aprender ou a formação de hábitos nos organismos superiores. As atividades destes organismos estão condicionadas por conseqüências de atividades anteriores, e, além disso, pelo fato de estarem dotados de receptores à distância, suas respostas às coisas próximas (receptores de contato) são também respostas às coisas que estão distantes. Desta forma, o remoto e o passado estão presentes na conduta. Entretanto, a atividade não é só de estruturas internas, é uma integração de conexões orgânico-ambientais em que a partir da experiência real algo se destaca e passa a

\footnotetext{
${ }^{20}$ Diz Dewey: "O resultado cognitivo é o mundo natural homogêneo da moderna ciência em contraste com o mundo qualitativamente heterogêneo da antiga ciência.” (Dewey, 1958, p. 143)
} 
tomar o foco, compondo uma série de interações. ${ }^{21}$ Ao concluir um circuito de interação (necessidade - satisfação), tanto meio quanto organismo sofrem modificações. Do ponto de vista orgânico, a integração promove um equilíbrio das energias; do ponto de vista do ambiente as condições são satisfeitas ${ }^{22}$. As mudanças nas estruturas orgânicas (do organismo) proporcionam uma retenção que condiciona o comportamento futuro do organismo, constituindo, desta forma, as estruturas chamadas de hábitos. Estas retenções orgânicas ou hábitos dão origem à memória. Diz Dewey: "Os hábitos representam a base do aprendizado orgânico." (Dewey, 1950, p. 46) Para ele, o hábito é a unidade que melhor expressa o circuito característico de todo comportamento.

As ações conjuntas dos seres humanos são possíveis graças à presença de sinais. Diz Dewey: "No ser humano, esta função passa a ser linguagem, comunicação, discurso, em virtude da qual as consequiências de uma forma de vida se integram na conduta de outra." (Dewey, 1958, p. 230) A comunicação promove um amplo aprendizado de hábitos em número e complexidade:

Comunicação não apenas aumenta o número e variedade de hábitos, mas tende a ligá-los sutilmente e, eventualmente a sujeitar a formação de hábitos, em um caso particular, ao hábito de reconhecer que novos modos de associação irão exigir um novo modo de uso dele. (Dewey, 1958, p. 231)

A formação de hábitos coloca para o ser humano um número crescente de necessidades e o leva a um novo relacionamento com o mundo. As condições apropriadas para o exercício dos hábitos levam o organismo a fazer as buscas e experimentalismos, a fazer variações e expor-se ao erro e fracasso. Mesmo nesse caso, tal exercício aumenta a susceptibilidade, sensibilidade e capacidade de responder. Assim, o processo de criação de hábitos coloca o organismo num processo de permanente aprendizado. Diz Dewey:

\footnotetext{
${ }^{21}$ Dewey explicita o processo com mais detalhes defendendo a importância de compreender o estímulo como o estado total do organismo que se movimenta devido a uma tensão. Estímulo não é uma sucessão de excitações sensoriais específicas, nem comportamento orgânico uma sucessão e composição de unidades de arco-reflexo independente. Ele apresenta o processo da seguinte forma: "Como de fato a conduta é uma função do estado total do organismo em relação com o meio, os estímulos são funcionalmente constantes apesar das mudanças em seu conteúdo específico. Em razão deste fato, a conduta é sequiencial, surgindo um ato do outro e levando todos cumulativamente a um novo ato, até que se consiga a atividade consumatória totalmente integrada." (Dewey, 1960, p. 31)

22 Dewey salienta a importância de compreender o circuito completo: "O que acontece no desenvolvimento normal da conduta é um circuito em que a primeira fase ou a 'abertura' é a tensão de vários elementos de energia orgânica, enquanto a fase final ou de 'encerramento' é a instituição de uma interação integrada do organismo e ambiente." (Dewey, 1960, p. 31, aspas do autor)
} 
Quanto mais aprende um organismo - isto é, quanto mais resultam retidos e integrados, na fase presente de um processo histórico, os termos anteriores tanto mais tem que aprender se quiser seguir adiante; caso contrário, temos catástrofe e morte. Se a mente é um processo mais de vida, um processo mais de registro, conservação e uso do que foi conservado, então deve ter traços empiricamente: o de uma corrente em movimento, de mudanças constantes, que, contudo, têm um eixo e direção, articulações, associações, assim como iniciações, hesitações e conclusões. (Dewey, 1958, p. 282)

Hábito é um conceito muito precioso e favorito na filosofia deweyana. Seguidamente Dewey retoma esse conceito em suas obras. No livro A natureza humana e a conduta (1922, 2002), ele desenvolve extensas discussões sobre esse conceito. Uma dificuldade que Dewey explicita é a de encontrar a palavra adequada para expressar o seguinte conjunto de idéias:

O tipo de atividade humana que é influenciada por atividades anteriores e neste sentido adquiridas; que contém dentro de si mesma uma certa ordem ou sistematização de elementos secundários da ação; que é projetivo, dinâmico em qualidade, pronto para manifestação pública e que é operativo, em alguma forma subordinada de controle, mesmo quando não é obviamente a atividade dominante. (Dewey, 2002, p.41)

Sua preferência é pela palavra hábito, mas reconhece que as palavras atitude e disposição poderiam também ser usadas desde que preservassem aqueles sentidos. Porém, essas palavras poderiam induzir ao erro com mais facilidades, uma vez que sugerem "alguma coisa latente, potencial, algo que requer um estímulo externo a si mesmo para se tornar ativa" (Dewey, 2002, p. 41) Por outro lado, o termo hábito dá a noção de operatividade, ou de atividade, sendo mais apropriado.

A opção pelo termo hábito permite articular várias idéias da filosofia deweyana para explicar o dinamismo entre ser humano e ambiente: a relação ativa organismo-meio com modificações em ambos e aprendizado do primeiro, o processo de funcionamento da mente, do comportamento, do caráter e do processo de aprendizagem. Neste sentido é possível dizer que para Dewey uma característica fundamental do ser humano é a de ser um complexo orgânico de hábitos, que interagem com o meio se auto-regulando e modificando-se, como forma de garantir a sobrevivência. Os hábitos e impulsos proporcionam uma estrutura de interatividade a partir da qual o organismo reage em função de sua adaptação ao ambiente possibilitando o crescimento. Isto leva Dewey a fazer dura crítica à concepção psicológica, que toma hábito como mera repetição. Esta tese coloca os carros diante dos bois, uma vez que repetição é resultado do hábito criado. Dewey compreende hábito como estrutura orgânica ou disposição adquirida num processo que envolve flexibilidade e readaptabilidade. O hábito é a própria vontade, como podemos perceber nas afirmações que seguem: 
Embora seja admitido que a palavra hábito tenha sido usada em algum sentido amplo do que é usualmente, nós devemos protestar contra a tendência da literatura psicológica de limitar o seu significado à repetição. Este uso está muito menos de acordo com o uso popular, que do modo amplo no qual nós usamos a palavra. Ele assume desde o início (começo) a identidade de hábito como rotina. Repetição não é em nenhum sentido a essência do hábito. A tendência de repetir atos é um incidente de muitos hábitos, mas não de todos. Um homem com o hábito de dar caminho à raiva pode mostrar seu hábito através de um ataque mortífero sobre alguém que o tenha ofendido. Seu ato é, todavia, devido ao hábito, mesmo quando ocorre somente uma vez em sua vida. A essência do hábito é uma predisposição adquirida para maneiras (ways) ou modos (modes) de resposta, não para atos particulares, exceto como, sob condição especiais, este expressa um modo de comportamento. Hábito significa uma sensibilidade especial ou acessibilidade a certas classes de estímulos, colocando preferências ou aversões mais do que simples repetição de atos específicos. Significa vontade. (Dewey, 2002, p. 41)

A idéia de hábito será fundamental para Dewey explicar a conduta e, desta forma, a ética e moral. Dewey encontra na idéia de hábito o circuito característico do comportamento humano ou da conduta. E a conduta é uma interação entre os elementos da natureza humana e do ambiente natural e social. (cf. Dewey, 2002, p. 10) Daí decorre que a moral, para Dewey, deve se basear no estudo da natureza humana, ao invés de ser indiferente em relação a ela. Este estudo deverá encontrar continuidade entre o homem, a natureza e a sociedade, aliando a ética com a física, a biologia, a história, a sociologia, as leis e a economia.

Dewey parte do princípio de que os hábitos são comparáveis às funções fisiológicas (respiração, digestão, etc.), com a diferença que eles são adquiridos. Hábitos são estruturas orgânicas ou disposições adquiridas na interação com as condições do ambiente, não sendo originalmente naturais. Eles representam a incorporação de forças objetivas que influenciam a conduta. Como os hábitos envolvem o suporte das condições do ambiente, a sociedade participa como acessória. Desta forma, todas as condutas são partilhadas, são sociais. Sempre haverá uma forma social de resposta aos hábitos através da aprovação, desaprovação, protesto, encorajamento, resistência e mesmo indiferença. Há uma cumplicidade social, manifestada através de ódio, admiração, imitação. Dewey tira conclusão importante desta concepção de hábito ao mostrar o comprometimento da sociedade no caso do crime: "matando alguém que faz o mal ou prendendo-o atrás de paredes de pedra, permite-nos esquecer ambos: ele e nossa parte na criação dele." (Dewey, 2002, p. 18) O tratamento da criminalidade deve levar em conta as causas e consequiências deste fato social, pois a mera punição corrobora mais para estimular novos crimes através da vingança e brutalidade do que para encontrar ajustamento social. 
Como Dewey pensa a possibilidade de mudança de hábitos? Dewey está discutido os hábitos como base para compreender a questão moral. Para ele a moral trabalha com atos que estão sob nosso controle, atos ainda a serem executados. Ele propõe que seja feita uma discriminação entre o componente físico e o moral. O aspecto físico diz respeito ao "que' e ao "como" acontece. Encontram-se nestes aspectos as forças que atuam e conduzem a ação de forma que o conhecimento delas auxilia no trabalho de incrementar as condições do ambiente. A questão moral diz respeito ao futuro das ações, ou seja, é prospectiva. Assim, Dewey prevê que o problema moral é de fazer esta articulação entre estes dois aspectos - o físico e o moral - e não apenas contentar-se com julgamento de mérito ou demérito. O julgamento é apenas parte do processo. Vejamos como ele coloca esta questão:

O problema moral é o de modificar agora os fatores que influenciam resultados futuros. Para modificar o funcionamento do caráter ou vontade do outro devemos modificar as condições objetivas que interagem com seus hábitos. Nossos próprios esquemas de julgamento, determinando culpa ou louvor, recompensando com culpa ou honra, são partes destas condições. (Dewey, 2002, p.19)

Para Dewey, a abordagem moral que se centra apenas na elaboração de esquemas de julgamento, baseada na convenção e na tradição tais como preleções, regulamentos, etc. são insuficientes e até mesmo podem desvirtuar a formação do caráter. Restringe-se a moral a uma lista de atos estabelecidos e carregada de um "piegas aspecto sentimental" desvinculada do seu alcance social. Ele faz questão de reforçar a necessidade de modificação das condições objetivas para a mudança dos hábitos: "Não podemos mudar o hábito diretamente: esta noção é mágica. Mas nós podemos mudá-los indiretamente através da mudança das condições, por uma inteligente seleção e valoração dos objetos que prendem a atenção e que influenciam a satisfação do desejo." (Dewey, 2002, p. 20) Ele contrapõe a durabilidade dos hábitos em relação à fragilidade dos discursos que aspiram as mudanças:

Nós podemos desejar a abolição da guerra, a justiça na indústria, maior igualdade de oportunidade para todos. Mas nenhuma quantia de pregação de boa vontade ou regras de ouro ou cultivo de sentimentos de amor e equidade irá lograr os resultados. Deverá haver mudança nos arranjos objetivos e nas instituições. Devemos trabalhar no ambiente e não meramente no coração do homem. Pensar de outro modo é supor que flores podem ser cultivadas no deserto ou carros podem rodar numa floresta. Ambas as coisas podem acontecer e sem milagre. Mas somente se primeiro forem mudados o deserto e a floresta. (Dewey, 2002, p. 22)

Dewey comenta o tratamento que se dá aos hábitos, quando o estudo começa analisando os maus hábitos, tais como preguiça, malícia, jogatina, dependência de drogas e álcool, etc. Eles são vistos como um poder mau que de alguma forma nos sujeita e devem ser 
expulsos do conceito que fazemos de nós mesmos. São tidos como algo formado sem nossa deliberação. Mas Dewey questiona esta visão perguntando como pode uma parte profunda de nós mesmos ser formada acidentalmente e sem intenção? Esta maneira de ver os hábitos é interessante porque mostra o que é um hábito e como eles constituem o próprio "eu", a vontade e o próprio pensamento. Vejamos as palavras de Dewey:

Estes traços do mau hábito são precisamente as coisas mais instrutivas sobre todos os hábitos e sobre nós mesmos. Eles nos ensinam que todos os hábitos são afeições, que todos têm força projetiva, e que a predisposição formada por um número de específicos atos é uma parte imensamente mais íntima e fundamental de nós mesmos do que escolhas vagas, gerais, conscientes. Todos os hábitos são demandas por certo tipo de atividade; e eles constituem o self. Em qualquer sentido inteligível da palavra vontade, eles são vontade. Eles formam nosso desejo efetivo e eles nos fornecem nossas próprias capacidades de trabalhar. Eles governam nossos pensamentos, determinam o que deve aparecer e ser duradouro e o que deve passar da luz para a obscuridade. (Dewey, 2002, p.25)

Dewey aprofunda a relação dos hábitos com o pensamento, a formação das idéias ou concepções. Para ele a formação de idéias assim como a sua execução depende de hábitos. (cf. Dewey, 2002, p. 30) Dewey retoma sua concepção de pensamento como ato derivado das ações. Diz ele: "O ato tem que vir antes do pensamento e um hábito antes de uma habilidade para evocar o pensamento à vontade. A psicologia ordinária inverte o estado atual de negócios." (Dewey, 2002, p. 30) Para ele, as idéias e conceitos não são gerados espontaneamente, nem são formas puras e imaculadas. Aqui Dewey tece críticas à idéia de uma "razão pura" ou "sensação pura". Suas palavras são as seguintes: "A razão pura, isenta dede toda a influência de hábito anterior é uma ficção. Mas puras sensações fora das quais podem ser moldadas idéias separadas do hábito são igualmente fictícias.” (Dewey, 2002, p. 31) E defende a dependência de ambos em relação aos hábitos: "As sensações e as idéias as quais são a "matéria" do pensamento e propósito são igualmente afetadas por hábitos manifestados em atos que dão aumento às sensações e significados.” (Dewey, 2002, p. 31). A dependência do pensamento, da concepção e da sensação da experiência não pode ser subentendida como uma experiência de pensamento puro ou sensações puras. As qualidades sensoriais não são elementos originais, mas produto de treino, habilidade, hábito. Diz Dewey: "Ser capaz de selecionar um elemento sensório definitivo em qualquer campo é evidência de alto grau alto treinamento prévio, quer dizer, de hábitos bem-formados.” (Dewey, 2002, p. 31) O hábito age como um meio de filtragem do material que atinge o pensamento e a percepção, acrescentando-lhe novas qualidades e rearranjando o material que é recebido. 
A natureza dos hábitos, afirma Dewey, depende da compreensão das relações entre meios e fins: "Um hábito significa a capacidade de utilizar as condições naturais como meio para a realização de fins." (Dewey, 1979b. p. 49) Meios e fins são dois nomes para a mesma realidade, ou seja, apenas uma distinção no julgamento sobre uma realidade indivisível. Ele esclarece essa continuidade entre meios e fins: "Fim" é um nome para uma série de atos tomados coletivamente - como o termo “exército'. "Meios" é um nome para a mesma série tomada distributivamente - como este soldado, este oficial." (Dewey, 2002, p. 36) O fim tem o papel de alargar a visão do ato a ser executado. Proporciona olhar para o próximo ato em perspectiva, sem deixar ocupar todo o campo da visão. Isto quer dizer que ter o fim em mente não deve impedir de pensar os próximos atos no curso da ação. Se o fim ficar distante, ele se torna um mero fim, vago, nebuloso, um sonho. O pensamento deve transformar o que (fim) em um como (meio). Assim, o fim é tratado como uma série de meios. "O meio é plenamente tão somente em seu fim.”, afirma Dewey (Dewey, 1958, p. 161) Podemos identificar a posição ocupada por diferentes atos no final do processo de desenvolvimento da atividade, de forma a dizer que o resultado corresponde ao fim e todo o processo como meios para se chegar a tal resultado. Neste sentido, diz Dewey, "cada passo tem seu interesse e sua significação adequado.” (Dewey, 1959b, p. 107) Em certas atividades - uma sobremesa em relação a um jantar, por exemplo - o fim se caracteriza como uma fase derradeira, consumatória. Em outras, o fim completa a sequiência de atos do processo como um todo.Exemplos são o jogo, uma música, etc. Dewey explicita esta distinção:

Enquanto a atividade se está processando, o 'fim`significa o objetivo, o termo final da atividade; implica na necessidade de observar estritamente o presente para ver se ele nos leva, efetiva e diretamente ao que temos que fazer depois. Concluída a atividade, o 'fim significa o produto realizado, como uma coisa externa e fixa. As mesmas considerações podem ser feitas em relação ao termo 'meio'. Durante a atividade significa o material ou os passos dados no curso do processo de execução. Terminado este, o próprio produto obtido, já distinto da atividade, pode por sua vez ser entendido como meio para a realização de uma outra coisa." (Dewey, 1959a, p. 110)

O fim deve aparecer em cada um dos próximos atos de um de um curso de ação. Neste caso, o que está mais próximo de nós o que está ao nosso alcance são os hábitos. Eles agem como forças propulsivas, movem em direção a um fim ou resultado projetado como um fim-em-vista. Diz Dewey:

Por 'fins` nós entendemos também fins-em-vista, metas, coisas vistas depois de deliberar como dignas de persegui-las e provocadoras de esforços. Eles são formados de objetos tomados pelo lado de suas qualidades diretas e terminais; objetos que têm acontecido alguma vez como finais, mas que não 
se encontram no presente na existência e que provavelmente não se encontrarão nela, salvo por obra de uma ação que modifique as circunstâncias. (Dewey, 1958, p. 104)

A experiência depende da operação dos hábitos que originalmente são instintos. Os hábitos não operam independentemente um do outro. O exercício e desenvolvimento de um afeta todos os outros. Se não existisse essa "contínua operação dos hábitos em cada ato" teríamos apenas um feixe desconexo deles. (cf. Dewey, 2002, p. 38) É o funcionamento interativo dos hábitos que define o caráter. Diz Dewey: "O caráter é a interpenetração de hábitos. Se cada hábito existisse num compartimento e operasse sem afetar ou ser afetado pelos outros, o caráter não existiria. Quer dizer, faltaria unidade à conduta se ela fosse uma justaposição de reações desconexas de acordo com as situações separadas. (Dewey, 2002, p. 38) Se, por outro lado, os hábitos estiverem divididos uns contra os outros, a personalidade fica rompida, a conduta confusa e desintegrada. A interpenetração dos hábitos promove a modificação contínua de um pelo outro. Este processo de integração dos hábitos nunca é total. Ela é sempre uma aquisição que resulta de um processo gradual de seleção no processo de modificação das condições do ambiente. Daí decorre para Dewey a natureza moral de uma situação: "A modificação mútua dos hábitos nos permite definir a natureza da situação moral." (Dewey, 2002, p. 39) De que forma? Certos hábitos podem em um determinado momento assumir o curso da ação. Esta operação não implica em si julgamento moral. Entretanto, qualquer ação, mesmo as mais triviais, pode requerer julgamento moral dos hábitos, considerando o conjunto da conduta. $\mathrm{O}$ fator moral está em saber quando deixar a ação correr ou quando submetê-la ao julgamento moral.

Importa ter claro que, para Dewey, a moral tem a mesma amplitude das relações que mantemos com os outros, incluindo todos os nossos atos, mesmo que explicitamente não estejamos atentos ao seu alcance social. O raciocínio que Dewey formula articulando os atos, hábitos e moral: "Pois cada ato, pelo princípio do hábito, modifica nossa mentalidade - fixa certas espécies de propensões e desejos. E é impossível dizer quando o hábito, que deste modo foi robustecido, pode ter influência direta e perceptível em nossa associação com os outros homens." (Dewey, 1979b, p. 393) Assim, se o caráter pode ser compreendido como multiplicidade e complexidade de hábitos, deve-se também compreender que os hábitos não operam isoladamente, mas interligados entre si. Seguidamente algum traço do caráter se destaca na relação social a ponto de adquirir a qualidade de moral como, por exemplo, a honestidade, amabilidade, etc. Acrescenta Dewey: "São por excelência morais, não por serem isolados e exclusivos, mas por se relacionarem tão intimamente com milhares de outras 
atitudes que não reconhecemos explicitamente - e para as quais talvez nem tenhamos nomes." (Dewey, 1979b, p. 393) Entretanto, dar nomes a estas atitudes isoladas de virtudes equivale a "tomar o esqueleto independente das demais partes do corpo que o mantém vivo. Por isso a moral compreende uma atividade integrada e eficaz. Diz Dewey:

A moral se interessa nada menos do que por todo o caráter, e esse caráter
total se identifica com o homem em todo o seu feitio e manifestações
concretas. Ter-se virtude não significa terem-se cultivado exclusivamente
alguns traços mencionáveis pelos nomes; significa ser plena e
adequadamente o que se é capaz de chegar a ser, por meio da associação
com as outras pessoas em todas as funções da vida. (Dewey, 1979b, p. 393)

Os hábitos são "condições de eficiência intelectuais" (cf. Dewey, 2002, p.172) Quanto mais numerosos eles forem mais amplo se torna o campo de observação e predição e quanto mais flexíveis, mais refinada é a percepção. O organismo encontra-se em situação de permanente balanço com seu ambiente, sofrendo constantemente interferência e restabelecimento. Dewey relaciona este processo com a idéia de W. James de "fluxo da consciência”, processo comparado ao movimento de um pássaro que alterna entre vôos e pousos. Diz Dewey, “A vida é interrupções e restabelecimentos.” (Dewey, 2002, p. 179) Como surgem as interrupções? Continua ele: "O distúrbio de ajustamento do organismo e ambiente é refletido num conflito temporário, o qual conclui por trazer a termo um velho hábito e um novo impulso." (Dewey, 2002, p.. 179) O impulso define o movimento e o foco de um novo curso da ação para o exame, a pesquisa, a inquirição em direção ao desconhecido daquela situação. Os hábitos fornecem matéria para satisfação, isto é, a experiência passada se torna aproveitável numa experiência similar no futuro. A modificação gerada numa experiência passada cria predisposição para uma ação eficaz e em direção similar. Assim, vida intelectual é uma operação conjunta entre hábitos e impulsos: Conclui Dewey: "O processo passa a ser objeto. Sem hábito, divisam-se tão somente irritações e hesitações confusas. Somente com o hábito haverá uma repetição à semelhança de um processo maquinal, uma intermitência duplicada de atos velhos. Com o conflito entre hábitos e liberação de impulsos haverá uma procura consciente.” (Dewey, 2002, p.180). Assim, em certa medida, os hábitos são empregados para dar nova forma ao conflito, esclarecendo-o num exercício da função inteligente. No caso de situações em que há novidade ou mudança nas condições, o conflito bloqueia a ação eficiente aberta e instaura a dúvida, dá origem à indagação consciente para evidenciar o problema. Este é o início do processo da investigação ou do pensamento reflexivo. O conflito gerado pelos hábitos prévios e o novo impulso, dá um novo direcionamento para a ação para o nível intra-orgânico. Há um esclarecimento importante que 
Dewey faz sobre a mudança do tipo de ação que ocorre neste processo: "A atividade não cessa de forma a dar passagem à reflexão; a atividade é convertida em execução dentro do canal intra-orgânico, resultando em dramático ensaio.” (Dewey, 2002, p.191) Este ensaio é parte do processo da investigação em que a mente recorre aos conhecimentos para suprir e poder trabalhar sobre o problema. Assim, há intima conexão entre hábitos e conhecimentos: "ao passo que um hábito, separado do conhecimento, nos proporciona um único método fixo de ação, o conhecimento significa poder-se fazer seleção dentre uma série muito mais ampla de hábitos. (Dewey, 1979b, p. 374)

Este "canal intra-orgânico" é a imaginação, onde se processa a deliberação e a escolha. Como Dewey entende esses conceitos? O primeiro momento que se pode identificar é a suspensão da atividade ${ }^{23}$, limitando-se a redistribuir as energias dentro do organismo como forma de preparar algum procedimento. A deliberação de um objetivo e de uma disposição toma algum tempo. A deliberação é a tentativa de procurar vários cursos possíveis de ação ou prognósticos: "Deliberação é um experimento para descobrir como realmente são as várias linhas de ação." E ainda, "Toda deliberação é uma pesquisa por modo (way) para agir, não para um término final." (Dewey, 2002, p. 198) A pesquisa é a trabalho do pensamento que leva adiante as possibilidades de hábitos e impulsos e prevê resultados promissores ou antecipa possíveis erros que poderiam ser fatais. Significa a possibilidade de cada hábito e impulso projetar a si mesmo nesta "tela da imaginação", manifestando qual seria o quadro final se fosse levada a efeito. A deliberação abre caminhos para a decisão. Desta forma ela cessa com a escolha que significa: "Simplesmente descoberta na imaginação de um objeto que fornece um estímulo adequado para o restabelecimento da ação aberta. A escolha é feita tão logo algum hábito, ou alguma combinação de elementos de hábitos e impulsos, encontra o caminho inteiramente aberto." (Dewey, 2002, p. 192) Teremos uma escolha razoável quando a deliberação foi razoável. Razoável significa que considerou as reivindicações em competição de cada hábito e de cada impulso. Significa para Dewey, "a presença de um objeto compreensível, um objeto que coordena, organiza e faz funcionar cada fator da situação que fez surgir o conflito, suspense e deliberação." (Dewey, 2002, p. 195) Todo este processo corrobora para a aquisição de uma instância chamada razão. Desta forma, Dewey

\footnotetext{
23 A suspensão da atividade não é um procedimento puramente psíquico que seguirá outro físico após a deliberação e escolha. O organismo age como um todo de forma que os estados de tensão e adaptações dentro do organismo evoluem para uma atividade unificada. Há continuidade no procedimento que passa do estado incerto para o estado determinado e mais completo.
} 
tem argumento para criticar a razão "pura", "fixa" "a priori” "primitiva". Não é uma força a ser evocada contra hábitos e impulsos. Diz ele: "Razão, a atitude racional, é uma disposição resultante, uma conseqüência e não um antecedente pronto que pode ser invocado pela vontade e ser colocada em movimento. [...] 'Razão' não é uma força antecedente que serve como uma panacéia. Ela é uma laboriosa aquisição de hábitos, necessitando ser continuamente trabalhada." (Dewey, 2002, p. 196-198)

Dewey mostra através desta discussão que o conhecimento, julgamento e crenças representam um resultado adquirido do trabalho dos impulsos naturais com o ambiente. $\mathrm{O}$ próprio conhecimento pode se transformar e se tornar uma atividade com seus próprios processos e fins, como acontece, por exemplo, no caso da educação. Entretanto, o princípio permanece o mesmo, a saber, de que o conhecimento é derivado da ação. Diz Dewey:

A razão para insistir neste fato não é a falta de apreciação do valor distintivo
do conhecimento quando ele entra na existência. Este valor é tão imenso que
poderia ser considerado único. O objetivo desta discussão não é subordinar o
saber a algum rude e vulgar fim utilitário. A razão da insistência sobre a
posição derivada do saber enquanto atividade radica num senso por fato e na
realização que a doutrina da separação original do poder e impulso do
conhecimento secciona-o das outras fases da natureza humana e resulta em
um tratamento não natural. O isolamento das disposiçães intelectuais dos
fatos empíricos concretos dos impulsos biológicos e da formação de hábitos
obriga a uma recusa da continuidade da mente com a natureza." (Dewey,
2002, p.186)

A continuidade da experiência é resultado das ações dos hábitos e do trabalho da inteligência. Esta tem a tarefa de prever o futuro de forma a que a ação tenha ordem e direção. Ela se ocupa com os princípios e critérios do julgamento. Os princípios funcionam como métodos de investigação e previsão que requerem a verificação nos acontecimentos. (cf. Dewey, 2002, p. 238-239) Há relação entre princípios e hábitos. Princípios são métodos para a inteligência e os hábitos para a ação. Aplicação difusa e aberta do hábito reflete o caráter geral de princípios. Dewey mostra como a presença de hábitos e princípios podem comprometer a continuidade da ação: “Assim como os hábitos que se ajustam à rotina dominam a atividade e a desviam de suas condições, ao invés de aumentar sua adaptabilidade, também os princípios tratados como regras fixas, ao invés de métodos auxiliares, conduzem o homem para fora da experiência" (Dewey, 2002, p. 238) Um hábito fixo representa a duplicação, recorrência, repetição. Que tem conformidade com princípios fixos. O trabalho da inteligência é também o de criar novos princípios. "De fato, as situações em que entram a mudança e o inesperado são desafios para a inteligência criar novos princípios. (Dewey, 2002, p. 239) Existem muitos princípios verificados historicamente e com prestígio reconhecido. 
Por exemplo, a máxima kantiana de se perguntar como gostaríamos de ser tratados num caso semelhante. Dewey propõe que eles não sejam abandonados em cada nova situação, mas que se observe como funcionam sob as novas condições e que sejam modificados para servir como instrumentos hipotéticos para julgar novos casos. Assim, a generalização é um instrumento da inteligência. "Um instrumento, diz Dewey, é alguma coisa para ser usada. Portanto, é alguma coisa a ser aprimorada notando como ela funciona.” (Dewey, 2002, p. 244) O trabalho da inteligência é o de continuamente rever, adaptar, expandir e alterar os princípios. A generalização é um instrumento indispensável para ser usado no caso dos princípios morais, especialmente quando a circunstância não é desejada. Ela atende á demanda de analisar as conseqüências de forma aberta, consistente, universal, evitando a tendência de considerar os nosso próprios casos como excepcionais, em comparação com os dos outros, ou de se render às influências dos próprios hábitos. Este trabalho de "ligar efeito com efeito numa corrente de continuidade" é o trabalho da razão. Daí a importância de aprender hábitos inteligentes: “O que nós precisamos são aqueles hábitos, disposições que conduzem a previsões imparciais e consistentes das conseqüências. "Então, nossos julgamentos serão razoáveis; nós seremos então criaturas razoáveis.” (Dewey, 2002, p. 247)

Dewey está polemizando com Kant especialmente por dois deslocamentos nas concepções dele: a primeira é a concepção de "razão pura" como mencionamos; a segunda, porque ao levar adiante a doutrina da universalidade da consciência sobre as questões morais ele separou os princípios e ideais morais da conexão com a experiência, excluindo toda referência a qualquer tipo de conseqüências.

A discussão sobre hábito é recorrente na obra deweyana. No livro Como Pensamos refere-se à relação hábito e aprendizagem através da linguagem da seguinte forma: "Os órgãos pelos quais apreendemos novas noções são os nossos hábitos.” (Dewey, 1979a, p. 265) O foco desta obra é investigar como pensamos para depreender daí a formação de hábito de pensamento reflexivo.

Em Democracia e educação, Dewey desenvolve longa discussão sobre hábitos, especialmente no Capítulo IV. Nesta discussão Dewey é cuidadoso no tratamento de uma outra rede de conceitos que se interligam ao de hábito. Um primeiro conceito importante é o de crescimento, que é assim apresentado como sendo o processo acumulativo da própria sociedade, que se renova a partir das direções e redireções do processo histórico, ou na expressão deweyana: "marcha cumulativa de ação para um resultado ulterior" (Dewey, 1979b, p. 44) O conceito de crescimento está intimamente ligado ao de imaturidade. Este conceito, 
especialmente o prefixo "i”, carrega um sentido positivo, contrapondo-se à idéia de carência ou vacuidade. Imaturidade tem o sentido de capacidade, enquanto uma aptidão ou um poder de; e de potencialidade, enquanto energia ou força. Ambas idéias corroboram para constituir o conceito imaturidade: "a capacidade e aptidão para desenvolver-se" ou, ainda, "uma força ou aptidão positiva - a aptidão para desenvolver-se." (Dewey, 1979b, p. 45, itálicos do autor).

Dewey alerta para a gravidade de tomar como pressuposta a noção de crescimento como alguma coisa que preenche o vazio entre o adulto e a criança e imaturidade como mera falta ou ausência. Neste caso, a criança é concebida de forma relativa com o adulto. O pressuposto desta concepção toma a idade adulta como um ideal ou padrão de medida, um fim estático e considera a criança como uma falta ou privação, imaturidade com deficiência. A adaptação é concebida erroneamente como "ajustamento estático a um ambiente fixo e o hábito como coisa rígida e mecânica." (Dewey, 1979b, p. 54) Desenvolvimento ou crescimento é terminar o processo ao fim do qual - a vida adulta como alvo fixo - não haveria mais educação, porque não haveria crescimento, desenvolvimento.

Contrapondo-se a esta concepção, a imaturidade tem aspecto positivo e construtor na medida em que representa a força ou aptidão para desenvolver as potencialidades. A criança é compreendida de forma intrínseca com suas próprias capacidades e demandas de crescimento. Assim a imaturidade traz em si uma possibilidade construtiva com dois traços: a dependência, ou interdependência que garante a sobrevivência e a plasticidade, que não se deve confundir com a mera impressão vinda do exterior. Plasticidade é, para Dewey, "aptidão de aprender com a experiência, o poder de extrair e reter dos fatos alguma coisa aproveitável para solver as dificuldades de uma situação ulterior" (Dewey, 1979b, p. 47) Aprender um ato traz a possibilidade de contínuo progresso e justifica o autor: “[...] porque se desenvolvem métodos bons para outras situações. Mais importante ainda, o ser humano aprende o hábito de aprender. Aprende a aprender." (Dewey, 1979b, p. 48) A plasticidade é essa “[...] capacidade de contrair hábitos ou de desenvolver determinadas atitudes." E complementa: "Os hábitos dão-nos o domínio sobre o meio e a capacidade de usá-lo para fins humanos.” (Dewey, 1979b, p. 49) Para Dewey, os hábitos têm dois aspectos: um passivo, outro ativo. O passivo consiste na nossa adaptação a uma parte do meio que não nos interessa modificar no momento e o valor de suas qualidades reside na facilidade, economia e eficácia na ação, tais como andar, falar, etc. e domínio do meio. Representam um equilíbrio geral e da atividade sobre o meio. Os hábitos passivos servem de ponto de apoio para a formação dos hábitos ativos. Estes 
formam as aptidões para readaptar a atividade às condições novas, a novos fins e subentendem reflexão, invenção e iniciativa. (cf. Dewey, 1979b, p. 44-57)

Os hábitos proporcionam dois tipos de controle no processo adaptativo: um sobre o meio e, através deste, o controle sobre os órgãos da ação. Assim, os hábitos passivos atuam como base para o crescimento do indivíduo. Quando se transformam em rotina, processos sem largueza de visão ou originalidade eles paralisam o desenvolvimento, pois a adaptação é passiva e o organismo se conforma ao meio e não cria aptidão para modificar este meio. Eles mantêm o organismo sob seu domínio e são tidos como "maus hábitos", como fumar, beber, etc. Escravizam os modos de proceder dos indivíduos, dissociando a inteligência dos mesmos e privando-os do exercício da sua liberdade. Os hábitos ativos constituem o próprio desenvolvimento ou crescimento contínuo na medida em que a adaptação modifica o ambiente para nossa própria atividade e o próprio organismo em um meio à medida que há acréscimo de significação na experiência deste.

\subsection{A origem biológica dos conceitos como instrumentos de significação}

$\mathrm{Na}$ origem, temos o organismo que não é uma estrutura. Segundo Dewey, o organismo é uma forma característica de interatividade não simultânea, mas sucessiva que não tem uma estrutura constitutiva de seu mecanismo, como o andar difere das pernas, o respirar dos pulmões. São qualidades das ações chamadas de psico-físicas. As qualidades das atividades orgânicas e psico-físicas dão à mente base e conexão com a natureza, ao dar estofo existencial e permitir a ocorrência das significações. Dewey explicita o caráter intelectualinstrumental das significações:

O conceito mesmo de significação cognoscitiva, de sentido intelectual, é o de que as coisas se subordinam no que elas têm de direto àquilo que elas pressagiam e dão evidência. Um sinal intelectual denota que a coisa não é tomada imediatamente, mas que se refere a alguma coisa que pode vir em conseqüência dela. Significações intelectuais podem ser apropriadas, gozadas e apreciadas; mas o caráter de significação intelectual é instrumental. (Dewey, 1958, p.128)

Aprofundemos mais as idéias de Dewey sobre o desenvolvimento de instrumentos. A relação meio-consequiência das significações é o que define o que é o instrumento: um instrumento é uma coisa usada como meio para chegar a certas conseqüências, ao invés de 
tomá-las direta ou fisicamente. É algo intrinsecamente relativo, antecipativo, previsível. Sem referência ao ausente, ou "transcendente" nada é um instrumento. (Dewey, 1958, p.185)

Isto implica dizer também que algo usado como instrumento traz em si uma distinção e uma identificação. Os animais estão privados de usar instrumentos neste sentido e limitados no que se refere ao pensar. Contam apenas com a estrutura corporal, geralmente fixa, para conseguir os resultados.

Por outro lado, as significações são também caracteres que incorporados à sensibilidade transformam a ação orgânica, fornecendo-lhe novas propriedades. Afirma Dewey: "Todo pensamento e significação têm seu substrato em algum ato orgânico de absorção ou eliminação, de busca ou rejeição, de destruição ou cuidado, de sinal ou de resposta." (Dewey, 1958, p. 290) Os atos biológicos persistem, mas ampliam infinitamente a significação a partir das recombinações possíveis, com o uso da linguagem, que torna acessível o contato com as aquisições dos outros, acumuladas historicamente. A comunicação modifica as formas orgânicas de agir, transforma acontecimentos em objetos ou coisas com uma significação, acrescentando-lhes novas qualidades, inclusive sedia a própria mente e dá condições de existência à consciência ${ }^{24}$. A linguagem é reconhecida como o instrumento da cooperação social e estabelece a continuidade entre a origem e desenvolvimento das significações $^{25}$. Dewey coloca a linguagem como o "instrumento dos instrumentos" (cf. Dewey, 1958, p. 186), ou seja, o próprio uso dos instrumentos está sujeito às condições aportadas na linguagem. A aptidão para responder às significações e empregá-las, não se limitando às reações dos contatos físicos constitui a experiência inteligentemente dirigida que diferencia o homem dos demais animais e o emancipa.

Dewey elabora a idéia de continuidade, como forma de combater as concepções que separam a vida orgânica e da mente da natureza física e vice-versa, e que por isso, dividem os objetos da experiência em dois mundos, o físico e o ideal. Ao produzir um dualismo entre mente e corpo, pensamento e natureza, essas concepções criam um falso e insolúvel problema ao se buscar a conexão entre ambas. Assim, com a introdução da idéia de continuidade, o pensamento, a deliberação e a imaginação, quando objetivamente dirigidos por significações

\footnotetext{
${ }^{24}$ Consciência, idéia, é aquela fase de um sistema de significação que em um dado momento, está passando por uma redireção, por uma transformação transitiva. (Dewey, 1958, P. 308)

25 A linguagem é uma função natural da associação humana; e suas conseqüências reagem sobre outros acontecimentos, físicos e humanos, dando-lhes significação ou sentido” (Dewey, 1958, p. 173)
} 
ou conceitos, são funções adicionais aos acontecimentos naturais, dando-lhe novas conseqüências. Desta forma, significações ou conceitos têm o caráter de método de ação, uma regra para usar e interpretar as coisas, sendo que a interpretação significa a descoberta de uma potencialidade, que produz certa consequiência. "As significações são regras para usar e interpretar as coisas, sendo toda interpretação uma atribuição de potencialidade para produzir certa consequiência." (Dewey, 158, p. 188) É importante salientar que Dewey compreende que o exercício do pensamento ou inteligência constitui parte das contínuas interações, próprias da natureza. Esclarece esta relação da seguinte forma:

A atividade inteligente do homem não é algo que repercute de fora na natureza, mas a natureza mesma que atualiza suas próprias potencialidades, em favor de um resultado mais rico e pleno de acontecimentos. A inteligência dentro da natureza significa libertação e expansão, como a razão fora da natureza significa fixação e restrição. (Dewey, 1929, p. 214-215)

$\mathrm{Na}$ análise desenvolvida até o momento procuramos compreender a origem e desenvolvimento dos conceitos a partir das concepções biológicas na teoria deweyana. Retomaremos a seguir à crítica de Dewey à filosofia tradicional buscando trabalhar de maneira especial a questão proposta anteriormente sobre conhecimento e conceito.

\subsection{O papel dos conceitos na investigação experimental}

A temática do conhecimento subjaz todas as obras da vasta produção teórica de Dewey. Uma das obras em que essa temática é abordada e nos proporciona ricas discussões para compreender esse problema é A busca da certeza: estudo da relação entre conhecimento $e$ ação. No início dessa obra, ele aprofunda a leitura da situação do homem no mundo marcada pela incerteza, perigo, acaso e azar e a sua busca de resposta. A busca de segurança diante das ameaças desse mundo foi encontrada inicialmente na forma de ritual, no âmbito da religião e, posteriormente, na própria filosofia e ciência. Houve uma mudança na forma, mas não no conteúdo, de buscar a certeza e a segurança. A religião narra a história num sentido fantástico e comovente e a filosofia o fez num discurso racional, guardando os cânones da lógica. Mas o conteúdo continuou o mesmo, na medida em que a filosofia que exaltou as atividades do intelecto, capaz de captar o ser universal, como um ser fixo e imutável, e por isso garantir a certeza absoluta que é reconhecida como conhecimento em seu sentido pleno. Filosofia clássica representa, para Dewey, um "porto seguro" que lhe dá segurança: "Na filosofia clássica, o mundo real é, essencialmente, um porto no mar revolto da vida, ancoradouro em meio às procelas do coração, abrigo em que o homem julga encontrar e 
sentir, com certeza, o supremo prazer da realidade." (Dewey, 1958. p. 126) Em contrapartida, desprezou a atividade prática, e toda possibilidade de conhecimento através da experiência exatamente por ser o mundo da incerteza, o mundo da limitação dos sentidos. Aqui emerge a fonte dos dualismos tão criticados por ele, ou seja, por um lado, um mundo inferior, mundo das aparências, governado pelas mudanças onde só cabe a mera opinião, o acaso, a incerteza, a probabilidade e, por outro lado, o mundo superior do Ser verdadeiro ou completo, o mundo das essências no qual é possível o conhecimento, que é demonstrativo, necessário, seguro e, portanto, universal, invariável, eterno e que nos dá a certeza. Esta teoria do conhecimento acredita que o pensamento pode acolher o material fornecido pela percepção corrente, eliminar as qualidades variáveis e, portanto, contingentes e chegar assim, finalmente, às formas fixas e imutáveis, recorrendo às operações puramente lógicas e racionais, tais como definição, classificação em gêneros e espécies e de elaboração silogística.

Dewey denomina essa teoria do conhecimento como expectadora diante do mundo:

A teoria do conhecimento é modelada de acordo com o que estava suposto ocorrer no ato da visão. O objeto reflete luz ao olho e é visto; isso faz diferença para o olho e para a pessoa que tem um aparato ótico, mas nada para a coisa vista. O objeto real é o objeto tão fixo em sua monárquica indiferença, que ele é um soberano para qualquer mente observadora que o fite. A consequiência inevitável é uma teoria expectadora do conhecimento. (Dewey, 1960, p. 23)

Esse pressuposto não foi abandonado nem mesmo pelas teorias que admitem alguma intervenção mental no processo de conhecimento e por isso, admitem a impossibilidade de conhecer a realidade tal como ela é, já que advogam que teríamos apenas um acesso a uma cópia defeituosa da mesma. Portanto, a raiz da concepção tradicional da filosofia, que se apóia na razão como órgão do conhecimento, se encontra na separação estabelecida entre conhecimento e ação, entre teoria e prática. Diz Dewey que a concepção tradicional "[...] se ocupa dos conceitos da mente e de seus órgãos e se supõe que tais conceitos podem formar-se adequadamente sem necessidade de observar o que ocorre quando os homens se põem a investigar e investigam com êxito." (Dewey, 1960, p. 86) Portanto, os conceitos são produtos do pensamento puro, separados de qualquer experiência e da participação dos sentidos.

Desta constatação, Dewey vê a necessidade de desenvolver uma teoria do conhecimento, cujos procedimentos cancelem essa separação. Propõe uma revolução no método de conhecer, o que significa inverter totalmente a relação tradicional entre conhecimento e ação. Neste sentido, ele elabora uma pauta da investigação experimental cuja mudança fundamental se dá nos seguintes termos: dependência do conhecimento de um fazer, 
de sua participação na experiência, da colaboração dos sentidos, de atividades corporais sobre coisas materiais, com ajuda de instrumentos que também são materiais, da necessidade de conceitos, ou idéias na condução do processo. Estas condições implicam em mudança da atitude frente ao material da percepção sensível direta, que a ciência antiga não prestava a devida atenção, pois se apoiava na especulação. Ele especifica da seguinte forma essa revolução no processo de conhecimento:

A investigação experimental oferece três características notáveis: A primeira é, sem dúvida, que toda experimentação implica um fazer, um agir externo, uma introdução de mudanças definidas no ambiente e na nossa relação com ele. A segunda é que o experimento não constitui uma atividade cega, senão dirigida por idéias que hão de cumprir as relações impostas pelo problema mesmo que provoca a investigação ativa. O último aspecto que dá seu pleno sentido aos dois anteriores, é que o resultado da atividade dirigida consiste na construção de uma nova situação empírica, na qual os objetos estão relacionados entre si de maneira diferente, de sorte que as conseqüências das operações dirigidas constituem os objetos que possuem a propriedade de ser conhecidos. (Dewey, 1960, p. 86)

Portanto, para Dewey o pensamento, ainda que seja indispensável ao nosso conhecimento da existência natural, jamais pode fornecer por si mesmo esse conhecimento. Isto implica dizer também que nossa ação no ato de conhecer é ação inteligente, porque é um processo de dirigir operações que estabelecem relações. Portanto, é ativa, é uma arte de domínio. Há um contraste com a idéia de razão característica da filosofia clássica, que carrega um padrão fixo e último, uma lei física à qual os fenômenos obedecem, uma norma humana a que devem obedecer as ações. Acrescenta Dewey que este método da inteligência visa introduzir mudanças que alterarão a direção dos acontecimentos. Quando a correlação de mudanças se converte em objeto de conhecimento, coloca em nossas mãos um instrumento de controle. E completa: "A atitude de controle nos liberta da sujeição do passado e visa ao futuro, à produção.” (Dewey, 1929, p. 101)

Em contrapartida a ciência grega e a medieval representam uma arte ou atitude de aceitação das coisas tal como se goza e sofre com elas. Afirma Dewey que essa ciência que adota categorias como descrição e explicação dos fenômenos naturais, tem caráter estético, porque é a percepção de tipo estético que interessa nas coisas, pelos seus traços qualitativos imediatos. Para Aristóteles, por exemplo, a quantidade é um acidente que não afeta e é indiferente à natureza do objeto, pois, para seu o ponto de vista estético, o que importa é o que é internamente completo, harmônico, auto-suficiente, e que se pode organizar em hierarquia de formas, desde o mais ínfimo até os superiores. Há uma revolução intelectual nas concepções de Descartes, que coloca a quantidade como a essência da matéria, e de Galileu 
que propôs uma mudança do qualitativo ao quantitativo, do heterogêneo ao homogêneo, das formas intrínsecas às relações, do gozo contemplativo à manipulação ativa, etc. Comenta Dewey a mudança no método da ciência: "Galileu e seus companheiros de ciência e filosofia (como Descartes e Hobbes) inverteram o método, afirmando que estas formas sensíveis são coisas a serem conhecidas, desafios à investigação, problemas e não soluções, nem termos da solução." (Dewey, 1958, p. 132) Essa revolução traz à tona a categoria do conflito e a conseqüente necessidade de reconciliação, que só se alcança com a investigação. A mudança implica um nova maneira de perceber a natureza, não mais como algo completo e perfeito, como na ciência grega, mas um universo aberto e em processo.

$\mathrm{Na}$ ciência grega, os objetos satisfaziam as exigências para o conhecimento, na medida em que se tomavam as qualidades imediatamente presentes. Na análise experimental, o material que sugere soluções se converte em algo que coloca problemas, são coisas a investigar. Há uma nova atitude diante dos objetos, pois estes, quando experimentados, primeiramente são equívocos, obscuros, fragmentários e deixam de responder a uma necessidade. Por isso, eles são reduzidos à forma de relação de interações a respeito de suas características quantitativas; passam a ser tomados como dados que significam "material que vai servir"; são indicações, provas, sinais, chave para algo que há de chegar; têm um caráter intermediário e não último; são meios e não algo final. Há interesse pelas mudanças, alerta aos problemas e à pesquisa, ampliando indefinidamente nossa habilidade de mudar e dirigir as mudanças, conforme desejamos. Dewey caracteriza da seguinte forma o objetivo dessa mudança de atitude, que se valendo da análise experimental, reduz os objetos a dados:

[...] o objetivo da ciência se encontra no descobrimento de relações constantes entre as mudanças, e não na definição de objetos imutáveis, subtraídos da possibilidade de alteração. Interessa-se pelos mecanismos dos acontecimentos e não pelas causas finais. Ao tratar do imediato e não do último, o conhecimento aborda o mundo em que vivemos, que experimentamos, em lugar de tentar escapar para um reino superior nas alas do intelecto. O conhecimento experimental é um modo de fazer e, ao igual de todos os modos de ação, ocorre em um momento, em um lugar e sobre condições determináveis, em conexão com um problema definido. (Dewey, 1929, p. 102)

A natureza do problema é circunscrita com os dados que dispomos e que suscita em nós uma idéia de uma operação a qual, se colocada em execução, pode desembocar numa situação em que será resolvida a perplexidade ou dúvida que provocou a investigação. Assim, a importância de um conceito só pode ser buscada como um recurso instrumental, que estabelece as relações necessárias para resolver a situação problemática: 
Se fossemos fazer uma incursão no desenvolvimento histórico da ciência no qual estão fixados os tipos de operações que definitivamente foram encontrados para efetivar a transformação de uma situação obscura e perplexa da experiência numa situação clara e resolvida explicaríamos o caráter dos conceitos atualmente empregados nas áreas mais desenvolvidas da reflexão ou investigação. Um caráter comum de todas essas operações científicas, que deve ser notado é: "São de tal natureza que descobrem relações" [...] Este conceito em conexão com outras operações, tais como aquelas que definem massa e tempo, convertem-se em instrumentos mediantes os quais se pode estabelecer uma multiplicidade de relações entre os corpos. Deste modo, os conceitos que definem as unidades de medida de espaço, tempo e movimento se convertem em instrumentos intelectuais que permitem comparar, e trazer sobre o mesmo sistema, todo tipo de coisas que não possuem entre si nenhuma semelhança qualitativa. A experiência original e grosseira das coisas é ampliada com um outro tipo de experiência, o produto da arte deliberativa, cujos conteúdos significativos são as relações e não as qualidades. (Dewey, 1929, p. 125, itálico do autor)

Dewey salienta que para a definição dos conceitos não existe nenhuma prova ou regra a priori, já que dependem da determinação das operações que se desenvolveram experimentalmente no curso das investigações reais. Originaram-se naturalmente na ação e são provados e melhorados no curso dela. É nesse livre jogo do pensar na experiência que se formam os conceitos:

A definição da natureza das idéias, em termos de operações a realizar, e da prova de sua validade pelas conseqüências destas operações, estabelece conectividade dentro da experiência concreta. Ao mesmo tempo, ao emancipar o pensamento da necessidade de provar suas conclusões pela referência exclusiva a uma existência antecedente, deixa abertas as possibilidades criadoras do pensamento. (Dewey, 1929, p.114)

Por sua vez, a validade de um conceito está intimamente relacionada com as conseqüências práticas: "De acordo com a investigação experimental, a validade de um objeto de pensamento depende das conseqüências das operações que definem o objeto de pensamento." (Dewey, 1929, p. 129, itálicos do autor)

Dewey desenvolve a teoria operacional e experimentalmente empírica dos conceitos. Parte dessa discussão já foi exposta anteriormente na explicação da origem das significações e da linguagem. O problema que ele se coloca é o de verificar se a teoria operacional das concepções fracassa, quando aplicada a objetos puramente matemáticos. Para responder a essa indagação Dewey analisa a origem dos símbolos a partir da ação. Seguiremos os passos de sua argumentação.

A ação realizada externamente produz conseqüências que nos envolvem e nos comprometem. Uma nova questão nasce a partir deste fato: como apropriar-se de um fim em vista sem necessariamente agir de forma a experimentar consequiências em atos concretos? 
Seria possível fazer uma projeção antecipatória de resultados de forma a assegurar ou evitar o seu resultado? Esta conquista é para Dewey um produto da vida social através da comunicação. A solução veio com o aparecimento dos símbolos. Tais símbolos que podem ser gestos, palavras ou construções mais elaboradas permitem um atuar sem agir externamente. (act without acting) Os símbolos permitem ao pensamento atos como definição e generalização. É possível ensaiar o ato usando símbolos antecipando e ponderar os resultados. A invenção ou descoberta dos símbolos constitui a maior proeza da história do homem. Permite-lhe um desenvolvimento intelectual ilimitado. O segundo grande passo aconteceu com o desenvolvimento de símbolos especiais, liberados do sentido vago, oscilante, acidental e dependente do contexto circunstancial imediato das palavras usadas para fins sociais. Afirma Dewey, que esta transformação significou a construção de instrumentos simbólicos, que permitem o avanço do pensamento para nível científico:

Esta liberação do crescimento acidental transformou as ferramentas toscas e ambíguas do pensamento em instrumentos delicados e precisos. Ainda mais importante foi o fato de que ao invés de ser adaptado o local e situações diretamente presentes eles foram fabricados com separação do uso externo direto e em relação de uns com os outros. Basta que alguém olhe para os símbolos da matemática para se dar conta de que as operações que eles designam são outras do mesmo tipo delas mesmas, ou seja, simbólicas e não real. A invenção de símbolos técnicos sinalizou a possibilidade de um avanço do pensamento do senso comum ao nível científico. (Dewey, 1929, p.152)

Estes instrumentos significam uma mudança de dimensão do concreto para o abstrato. A dimensão do concreto - operações materiais - representa a utilização das coisas como meios empregados diretamente, ou como fins apropriados ou gozados de forma direta. Um uso concreto da matemática ocorre quando é empregada numa construção ou numa relação de compra e venda. O uso abstrato - operações simbólicas - representa a liberação da aplicação e uso existencial concreto para operações que visam facilitar e dirigir outras operações também de ordem simbólica. Por exemplo, a medição de um triângulo como meio para medir outras áreas também designadas simbolicamente. Isto permite construir um sistema de conceitos relacionados entre si. Abstração significa a possibilidade do pensamento liberar, de uma experiência, uma significação, e assim desprendida, passa a operar na forma de generalização na medida em que transfere o significado para a compreensão de novas experiências. Diz Dewey: "Em verdade, o abstrair da humana experiência não é senão um emancipar-se de gozos familiares e específicos que proporciona meios para descobrir conseqüências não colocadas à prova ainda, inventar e criar novas necessidades e novas formas de bem e de mal (Dewey, 1958, p. 193) A abstração é a "artéria da inteligência", do 
ato de intencionalmente tornar-se uma experiência aproveitável para orientar outra." (Dewey, 1979b, p. 248) Assim, abstração trabalha cooperativamente com a generalização, tornando os "instrumentos intelectuais" mais flexíveis, adaptáveis ao uso e aplicação em novas observações. No raciocínio deweyano: "A generalização aqui transfere, amplia, aplica um resultado da experiência anterior à recepção e interpretação de outra nova e posterior. $\mathrm{O}$ processo dedutivo define, delimita, purifica e coloca em ordem as concepções através das quais esta operação enriquecedora e direta é levada a efeito, porém, não pode, por mais perfeita que seja, garantir resultado, êxito.” (Dewey, 1959a, p. 1155) A generalização tem caráter essencialmente social. Diz Dewey: “A abstração e a generalização científicas equivalem a assumir-se o ponto de vista de todos os homens, sejam quais forem seus lugares no tempo e no espaço.” (Dewey, 1979b, p. 249)

A origem e o sentido desta ciência de conceitos, ou de sentidos, que desenvolve as operações possíveis em suas relações lógicas, radica-se em atos que tratam de situações concretas existenciais. As experiências reais dos homens através das operações abertas ou atos concretos de cortar, marcar, dividir, estender, juntar, agrupar, mesclar, repartir, contar etc. constituem a origem do número e de todo desenvolvimento das relações matemáticas. "Desta relação de causa e efeito, empiricamente expressa e confirmada, é que nascem as normas e regulamentos de uma arte de pensar.” (Dewey, 1959a, p. 142) A normatividade da matemática é resultado da longa história de crescimento, milênios de árduas experiências de êxitos e malogros empíricos. Dewey comenta o desenvolvimento dos conceitos matemáticos de quantidade e medida aplicáveis à observação e interpretação dos fenômenos naturais. Eles representam o método que se aperfeiçoa: "Pelo emprego dos conceitos de quantidade, podemos ignorar as diferenças de qualidades, que separam as coisas umas das outras e impedem, assim, a inferência." (Dewey, 1979, p. 180) Veja-se o caso do conceito "cor" que é concebido sob a base de números: como conceito popular, reúne qualidades como vermelho, azul, etc.; como conceito científico, usa-se o conceito de frequiência de vibrações que permite relacioná-lo a outros de espécie diferente em aparência: raios infravermelhos e ultravioletas, radioatividade, etc. Diz Dewey, as concepções são válidas na medida em que, por meio desses números, podem predizer eventos futuros, e podem regular as interações dos corpos coloridos como sinais que toman lugar. (Dewey, 1960, p. 129) Desta forma, o procedimento da matemática ajuda a compreender o caráter funcional dos conceitos: "A prova de validade de qualquer conceito, medida ou enumeração intelectual é funcional, isto é, se servem ou não 
para estabelecer interações que resultam em domínio ou controle das experiências reais dos objetos observados. (Dewey, 1929, p. 129)

Neste ponto reside e incapacidade do empirismo de Hume e Mill de explicar as idéias matemáticas. O caráter sensualista de sua empreitada os levou a buscar a origem das idéias matemáticas em impressões sensíveis, e não em reconhecer que estas funcionam como estímulo e registro de atividades motoras empregadas para fazer coisas.

Dewey considera errôneo também o argumento que defende que a experiência diz apenas o modo como os homens têm pensado ou produzem pensamento - descrição empírica -, enquanto que a lógica se relaciona com o modo como os homens devem pensar - descrição normativa. Contra-argumenta Dewey: “A lógica se reveste de importância profundamente humana, precisamente porque se funda no empirismo e suas aplicações têm base na experiência. Assim considerando, o problema da teoria lógica não é outro senão o da possibilidade do desenvolvimento, e emprego do método inteligente de conduzir pesquisas atinentes a uma reconstrução deliberada da experiência. (Dewey, 1959a, p. 142)

Dewey aponta também o limite do nominalismo e conceptualismo. O mérito está no fato de pregarem que os termos gerais, abstratos, universais não representam objetos reais existentes, mas são meras palavras, nomes, conceitos mentais ou verbais e as classificações e sistemas têm apenas caráter teleológico, visando fins mais eficientes e econômicos. Entretanto, seu erro foi negligenciar o lado ativo da experiência, ou seja, a interação variada que ocorre entre os diferentes modos de agir das coisas concretas e os diferentes interesses e aspirações dominantes dos indivíduos. Esta é a base sob a qual ocorrem as seleções, agrupamentos e classificações. O critério das classificações é a necessidade de execução de um fim e não meramente para fins mentais ou verbais. Dewey coloca nos seguintes termos a sua diferença com o nominalismo: "Conveniência, economia e eficiência são as bases para a classificação, mas essas coisas não se restringem a comunicações verbais com outras, tampouco com uma consciência interior; concernem à ação objetiva, hão de efetivar-se no mundo. (Dewey, 1959a, p. 157)

A outra observação de Dewey é que o nominalismo não considera a palavra como forma de ação social, através da qual um grupo realiza seus fins. Uma palavra passa a ser palavra com a aquisição de significado e isto ocorre quando se estabelece uma comunidade de ação e não simplesmente através de uma existência física particular. O nominalismo considera a palavra como uma expressão de um estado psíquico acabado e exclusivamente individual 
advindo de uma sensação, imagem ou sentimento. Ignora a linguagem como uma forma de relação, interação e associação.

A criação de símbolos que tornam possível investigar as implicações recíprocas das operações, ou, dizendo de outra forma, as operações possíveis que podem ser designadas por símbolos e executadas unicamente por meio deles, representaram o desenvolvimento de uma "lógica das idéias", dando a estas operações simbolizadas força intelectual de assertividade e compreensão. Ela permitiu também o desenvolvimento de regras de inter-relação das operações, possibilitando revisar e ampliar constantemente o próprio material. Cada grupo de operações simbólicas, tais como o da matemática, torna possível um número ilimitado de operações a serem executadas. As possibilidades de operações estão sujeitas à regra da não incompatibilidade, que evita que elas conflitem entre si, e do rigor no tratamento das copossibilidades formais. Símbolos técnicos são desenvolvidos com esta finalidade. Eles se distinguem de termos e idéias casuais por três características: "São selecionadas a fím de que designem univocamente um só modo de interação. Eles são relacionados com os símbolos das outras operações para formar um sistema que permita a transição de uns aos outros com a máxima economia de energia. E o ideal é que estas transições possam ocorrer na medida do possível em todas as direções." (Dewey, 1929, p.158) Os conceitos científicos não se prendem às qualidades das coisas encontradas pela percepção e usos diretos. Estas são finalidades. Eles buscam o modo de produção destas qualidades, ligando-o a uma multiplicidade de outras condições causais de maneira econômica e efetiva. Assim, o desenvolvimento dos símbolos, com independência de sua execução prática, oferece ao pensamento a possibilidade de livrar-se de sua "submersão na existência", que atua sobre ele de forma física e sensível, e ao mesmo tempo, um retorno ulterior às operações existenciais, com mais alcance e força de penetração nunca antes obtida.

As operações simbólicas significam a possibilidade de descobrir as relações de meioconseqüência. Pensar algo como meio é captar um objeto em relação que proporciona um efeito físico apreciado como consequiência. Dewey chama este tipo de relação como ideal no sentido de ideacional. Isto porque as relações meio-conseqüência permanecem uniformes e invariantes. Além disso, são padrões que servem para avaliar os processos existenciais. Como uma possibilidade formal, as relações ideais de meios e fins resultam sempre numa estrutura formal. As relações de implicação destas estruturas tornam possíveis a dedução. A dedução é uma operação que busca desenvolver as implicações, podendo resultar em novas implicações. Este processo permite o desenvolvimento ilimitado de conceitos gerais. Por serem de caráter 
abstrato, eles são também hipotéticos, ou seja, sua ideação está sujeita à prova definitiva. Desta forma, permanecem sujeitos a renovação em cada processo de dedução. A experiência humana é guiada de forma consciente pelos conceitos expressos em idéias, critérios e pautas, oferecendo, também, elementos intelectuais para novos ideais. Estas hipóteses - planos antecipadores da ação - tornam nossa relação intelectual e prática com a natureza mais livre, segura e significativa. Diz Dewey: “Todo ato inteligente, toda função mental inteligente resulta num incremento da liberdade de ação - emancipação, independência da sorte e fatalidade." (Dewey, 1959a, p. 149)

Para Dewey, esta maneira de conceber os conceitos mostra a maneira falsa de concebê-los no racionalismo e no empirismo. Eles recorrem ao caráter a priori dos conceitos. Para o empirismo, a origem, conteúdo e validade do conceito estão relacionados a uma existência anterior. Assim, os conceitos seriam formados pelo processo de comparação, eliminação e conservação, resultando das características idênticas dos objetos percebidos. Eles servem para juntar coisas esparsas na experiência. Sua prova depende do acordo com as experiências particulares anteriores, e, portanto, o valor e função deles é sempre retrospectivo e não tem a função de regular situações novas. Eles invertem os fatos, na medida em que imputam à razão um caráter $a$ prior,i de proceder à generalização dos conceitos. Neste processo, os conceitos seriam os elementos comuns que resultaria da comparação de certo número de fatos.

Assim Dewey quer mostrar a ampliação, modificação e variação das significações que é possível fazer através do pensamento simbólico das ciências, além de proporcionar grande emancipação e aumento do controle intelectual. Entretanto, o maior valor não está só na elaboração e consistência das hipóteses, mas nas conseqüências que acarretam para a existência tal como pode ser perceptivelmente experienciado. Diz Dewey: "Os conceitos científicos não são revelações de uma realidade prévia e independente. É um sistema de hipóteses, formuladas sob condição de uma prova definida, em virtude da qual nosso trânsito intelectual e prático com a natureza se faz mais livre, mais seguro e mais significativo." (Dewey, 1929, p. 165) Os resultados trazidos pela ciência lançam um desafio à Filosofia que é o de "[...] considerar a possibilidade de estender o método da inteligência operativa à direção da vida em outros campos." (Dewey, 1929, p. 169)

Assim como a matemática, cada ramo da ciência desenvolve um grupo especializado de conceitos que permite compreender os fenômenos classificados em cada campo específico. O especialista em cada ciência busca desenvolver tais conceitos em suas relações lógicas de 
interdependência, de subentendimento que, em certo sentido, é um jogo de idéias pelas suas relações de causa e conseqüência. Dessa forma, desenvolve-se a ciência específica, além de cultivar a inteligência pessoal e, mesmo, proporcionar satisfação intelectual.

Os conceitos, como instrumentos, são hipotéticos. Isto implica dizer que sua importância se relaciona com a capacidade de produzir resultados. O raciocínio de Dewey sobre o caráter hipotético das concepções pode ser assim colocado: "São elas instrumentos e, de conformidade com o que acontece a todos os instrumentos, os seus valores, longe de serem intrínsecos, residem na capacidade de trabalho, capacidade esta que se verifica tão só nos resultados de seu funcionamento, no seu rendimento.” (Dewey, 1959a, p. 150) Outra implicação é que os conceitos podem ser aperfeiçoados. Para isso é necessário estar alerta para notar sua vulnerabilidade ou sinais que os confirmem. Este processo de renovação e eliminação forma o acervo de conhecimento em constante ampliação:

O conceito e os sistemas de conceitos, fins em vista e planos estão constantemente sendo feitos e refeitos, tão rapidamente quanto revelem sua fraqueza, defeitos e valores positivos. Não existe um curso predestinado que devem seguir. A experiência humana conscientemente guiada por idéias desenvolve seus próprios padrões e pautas e cada nova experiência construída por estes meios é uma oportunidade para novas idéias e ideais. (Dewey, 1960, p. 167)

Dewey leva sua teoria de operacional e empírica dos conceitos também para o campo da moral, onde os valores são construídos pela inteligência, e podem ser testados objetiva e empiricamente, uma vez que se caracterizam como previsões de conseqüências da ação. Os valores são resultados da atividade inteligente que desenvolve planos de ação. Ao considerar a consequiência de uma ação, ou seja, a consecução de um fim, produz-se um juízo de valor e exige que se reconheça a continuidade entre meios e fins. Estes têm que ser deliberados de forma a cooperarem na prática para não haver o malogro da ação. $\mathrm{O}$ uso de meios para a consecução de um fim implica em estabelecer a continuidade entre meios e fins.

Assim, temos uma reviravolta, das concepções que buscavam a certeza e a segurança na razão absoluta, para a inteligência prática, investigativa: "A certeza teórica é assimilada como certeza prática; a segurança, na confiabilidade das operações instrumentais." (Dewey, 1929, p. 128)

Confirma também a pesquisa de Amaral, que Dewey encontra solução para os dualismos, na idéia de experiência inteligente:

[...] ele fundiu todos os dualismos ao colocar como centro de seu mundo a experiência inteligente do homem, a única capaz de alterar o curso dos 
acontecimentos em função dos fins definidos. Ele substituiu, portanto, a separação entre a experiência e a natureza, não pela idéia de continuidade entre ambas, mas pela fusão de ambas em um único conceito: o de experiência humana. A partir dessa fusão, foi fácil para ele 'encontrar' a continuidade entre os dois mundos antes separados. Desaparece, assim, o abismo entre o pensamento e a realidade. E, assim sendo, o homem não se dissolve em meio ao processo contínuo da evolução universal, mas pelo contrário, é o próprio elemento controlador do referido processo graças à sua experiência inteligente. (Amaral, 1990, p. 55) 


\section{CAPÍTULO III}

\section{CONCEITO E SUA FUNÇÃO SOCIAL - PENSAMENTO REFLEXIVO E A TEORIA LÓGICA DA INVESTIGAÇÃO}

A concepção de pensamento reflexivo ou da teoria lógica da investigação é desenvolvida por Dewey em quatro obras, ao longo de sua produção teórica, num período de mais de quarenta anos de atividades como professor e escritor. Acompanhemos a declaração de Dewey no prefácio da obra de sua maturidade - Lógica. Teoria da Investigação (1938):

Este livro é um desenvolvimento das idéias sobre a natureza da teoria lógica que foram apresentadas antes, há cerca de 40 anos, em meus Studies in Logical Theory [1903], que foram um tanto ampliadas nos Essays in Experimental Logic [1953] e resumidas prontamente, com especial referência à educação no volume How We Think. [1910 e 1933] Embora as idéias básicas permaneçam as mesmas, existem naturalmente consideráveis modificações durante este tempo transcorrido. Enquanto se mantém a conexão com o problemático, a identificação expressa do pensamento reflexivo com a investigação objetiva, eu acredito ser um modo de apresentação menos exposto a incompreensão que em casos anteriores. (Dewey, 1960, p. 3)

Dewey deixa claro que a questão central destas obras é tratar da dimensão do problemático na experiência através do pensamento reflexivo, que é identificado com a lógica da investigação. A obra Como pensamos é um sumário antecipado das concepções decantadas na obra Lógica. Teoria da Investigação. Em ambas, os conceitos desempenham um papel fundamental no processo de clarificar situações confusas na experiência a fim de equacionar a situação problema e que se configura no método do pensamento reflexivo, conforme apresenta na obra Como Pensamos: “As concepções são instrumentos intelectuais utilizados no material da percepção dos sentidos e da memória, para clarear o obscuro, pôr ordem no conflito aparente, trazer unidade ao fragmentário." (Dewey, 1979a, p. 178) Ele retoma esta idéia na obra da Lógica:

O conceito básico da investigação, como determinação de uma situação indeterminada, não somente permite que se obtenha uma solução do debatido tópico da relação entre o juízo e as proposições, mas, em conexão com a relação conjugada entre o material observado e o conceitual, permite também uma explicação coerente das diferentes formas de proposição. (Dewey, 1960, p. 3, itálico nosso)

Na obra Lógica. Teoria da investigação Dewey percorre ponto por ponto a lógica tradicional interpretando-a e reconstruindo-a a partir sua concepção da experiência 
problemática, ou do processo dúvida-investigação, a fim de pôr de acordo a teoria lógica com a prática científica. A teoria lógica está pautada pelo princípio de continuidade da investigação tal como Peirce já o havia salientado. O princípio de continuidade permite a Dewey dar uma compreensão empírica para as formas lógicas, rompendo com qualquer interpretação a priori das mesmas. O objeto da lógica é, para Dewey, naturalista e experiencial, biológico e cultural. Os conceitos são considerados lógicos e a lógica é tomada como história natural do pensamento.

A crítica de Dewey dirige-se a toda tentativa de delimitar o objeto da lógica desligado do processo de investigação. Decorre daí sua posição de considerar a lógica como sendo uma hipótese que se adota, e indica uma posição a se desenvolver. E o que se assume como objeto da lógica é tomado como hipótese, o que significa que deve preencher os seguintes requisitos: deve ter a propriedade de existência verificável em algum domínio, seja capaz de ordenar e explicar o objeto imediato e deve explicar os argumentos que se colocam em apoio a outras teorias. (cf. Dewey, 1960, p. 3) Vejamos como ele resume sua posição em relação à lógica:

A teoria, em forma sumária, consiste em que todas as formas lógicas (com suas propriedades características surgem dentro da operação da investigação e diz respeito ao controle da investigação de forma que esta pode produzir ou fornecer (dar lugar) a asserção garantida. Esta concepção implica muito mais do que afirmar que as formas lógicas são descobertas ou vêm à luz quando refletimos sobre os procedimentos da investigação que estão em uso. Claro que significa isso, mas também significa que as formas lógicas se originam nas operações da investigação. Para empregar uma expressão, diríamos que assim como a investigação da investigação é a causa cognoscendi das formas lógicas, a investigação primária é, por sua vez, a causa essendi das formas que a investigação da investigação descobre. (Dewey, 1960, p. 4)

Dewey coloca como hipótese inicial que os princípios lógicos surgiram da própria história da ciência. Ele observa que o desenvolvimento do método ocorre devido a um “criticismo imanente", num contínuo processo autocorretivo. Os métodos melhoram com o uso e pelo uso. No caso das artes industriais, por exemplo, a metalurgia, o progresso não se dá pela aplicação de critérios externos, mas pelas normas que se desenvolvem durante o processo. Os procedimentos que operam e levam ao êxito persistem e são melhorados, enquanto que os que fracassam são esquecidos. Se o progresso da tecnologia se deve ao desenvolvimento da ciência matemática e física, isto não significa a aplicação de "cânones" externos, aos quais as artes industriais têm que se submeter. Significa tão somente a possibilidade de funcionar com um instrumento a serem submetidos ao uso: "eram postos em uso e o resultado de seu emprego, de seu fracasso ou de seu êxito em cumprir com os fins ou 
alcançar os resultados foi o que forneceu o critério final de validade dos princípios científicos para levar adiante determinadas operações tecnológicas." (Dewey, 1960, p. 4)

Para o autor, a investigação começa na condição de dúvida e termina instituindo condições que eliminam a dúvida. Este estado final da investigação pode ser designado pelos termos crença, conhecimento ou por "asserção garantida". Esta expressão é preferida por Dewey diante da confusão que os outros dois termos podem provocar.

Por que Dewey prefere o termo "asserção garantida", aos termos crença ou conhecimento? Crença é uma palavra ambígua, segundo ele, e por isso inadequada. Por um lado, tem o sentido genuíno de ser o resultado de uma investigação, estabelecendo um novo estado de coisas, uma condição resolvida, predispondo a atuar externamente ou em imaginação de acordo com um modo determinado. Se a investigação começa com a dúvida, termina com uma crença. Mas, no uso popular, crença pode designar algo pessoal, uma certa posição que alguém mantém, tomando um sentido psicológico de estado psíquico ou mental. A palavra conhecimento também padece do mesmo problema que crença, ou seja, é ambígua. Por um lado, é truísmo ou tautologia afirmar que o fim da investigação é conseguir o conhecimento ou a verdade, já que estes, por definição, são considerados o resultado satisfatório ou a conclusão da própria investigação. Por outro lado, pode-se afirmar que o conhecimento tem um sentido em si mesmo, ou seja, é instituído à parte do processo de investigação e, em geral, definido a partir deste suposto. Por conseqüência, a teoria da investigação fica submetida a confusões, uma vez que está subordinada a este sentido de conhecimento, como um fim fixo e externo. Como há diversas concepções de conhecimento conforme a diversidade de realismos, idealismos e dualismos, a maneira de interpretar as formas lógicas fica submetida às pré-concepções da metafísica ou epistemologia subjacente.

O conhecimento é, para este filósofo, o resultado de alguma investigação particular. Neste sentido o conhecimento é a generalização daquelas propriedades descobertas e que fazem parte do resultado ou conclusão de uma investigação. Quando tomado em sentido abstrato, o sentido do conhecimento é um vácuo que pode ser substituído por qualquer coisa. A concepção de conhecimento como resultado da investigação tem efeito sobre a concepção de investigação. A este respeito, afirma Dewey: "indica que investigação é um processo contínuo em qualquer campo em que é empreendida." (Dewey, 1960, p. 8/9) Isto porque nada garante que uma conclusão estabelecida por um processo de investigação permanecerá sempre segura. Não há crenças que estejam isentas de investigações futuras. Assim, o conhecimento 
tem para ele o sentido de ser uma potencialidade, mais do que uma atualidade, constituindo um processo em contínua renovação:

O que define o conhecimento em seu sentido geral é o efeito convergente e cumulativo da investigação contínua. Na investigação científica, o critério do que se considera como assentado, ou como conhecimento, é o de ser tão estabelecido de forma que possa ser empregado como recursos de investigações ulteriores; e não estar assentado de tal forma que não seja objeto de revisão em investigações futuras. (Dewey, 1960, p. 8/9)

Desta forma, justifica-se para Dewey o uso do termo "asserção garantida", para mostrar que todo conhecimento resultante de um processo específico de investigação é parte de uma empresa que constantemente se renova. O processo da investigação contínua tem que ser compreendido como empírico e neste sentido racional. Racional ou razoável é uma questão de relação entre meios e consequiência e é desta forma que se descobre porque alguns métodos fracassam e outros obtêm sucesso. Esta relação é fundamental para compreender a teoria lógica:

A posição aqui adotada, a hipótese geral que antecipamos, é a generalização
da relação meios-consequência, característica da investigação matemática e
física. De acordo com ela, todas as formas lógicas, tais como são
representadas pelo que tem sido chamado de objeto imediato da lógica, são
exemplos da relação entre meios e conseqüências na investigação
adequadamente controlada, e, neste contexto, a palavra 'controlada' quer
dizer que se empregam os métodos de investigação desenvolvidos e
aperfeiçoados no processo da investigação contínua. Nesta continuidade, as
conclusões de qualquer investigação particular estão subordinadas ao uso na
comprovação e maturação de métodos de investigações futuras. O caráter
geral do conhecimento, como um termo abstrato, está determinado pela
natureza do método em uso e não vice versa. (Dewey, 1960, p. 8/9)

Assim, a própria teoria lógica está sujeita a mudanças conforme melhoram os métodos das ciências. A lógica é concebida como uma disciplina que progride na medida em que analisa os métodos de investigação de seu tempo e os considera melhores em função da continuidade da investigação. A lógica assim compreendida contrapõe-se à idéia da racionalidade hipostasiada, na qual as formas lógicas têm as premissas definitivas formuladas com base nos primeiros princípios fixos, captados a priori pela razão, ou ainda conteúdos, como é o caso da criteriologia da neo-escolástica.

Dewey comenta que os chamados princípios da lógica - identidade, contradição e terceiro excluído - tem sua origem e uso na experiência, ou seja, eles foram gerados no processo de controle da investigação continuada e não são princípios fixados a priori à investigação. Dewey recorre à explicação de Peirce sobre os princípios guias para explicar a origem de tais princípios. A explicação se dá pelo conceito de hábito. Estes operam como 
base de nossas inferências no nível biológico, sem que tenhamos consciência deste processo. Apenas posteriormente, detemo-nos e observamos o que se faz e como se faz. Assim, notados e observados como uma maneira ou modo de ação, os hábitos se transformam em princípios guias ou diretivos, ou regra de ação. A validade destes princípios dependerá da coerência das conseqüências que produzem com os hábitos que operam. O resultado deste processo é que estes princípios se tornam operativamente $a$ priori em relação às investigações que sucedem à sua descoberta. Afirma Dewey: "Estes princípios lógicos diretivos não são premissas da inferência ou da argumentação. São condições que hão de ser as satisfeitas, de tal sorte que o conhecimento delas nos proporciona um princípio de direção e prova." (Dewey, 1960, p. 13, itálicos do autor)

Chegamos assim ao ponto central de nossa discussão, que é a relação do conceito com a lógica. Dewey esclarece esta questão ao mostrar como o objeto da lógica é determinado operacionalmente. Operacional não é substitutivo para instrumental. Esta diferenciação é estabelecida da seguinte forma por Dewey:

Como termo geral, 'instrumental' significa a relação de meios-conseqüência, como a categoria básica para a interpretação das formas lógicas, enquanto 'operacional' significa as condições pelas quais o objeto é (1) tornado apto para servir de meio e (2) funcione realmente como tal meio ao efetuar a transformação objetiva que é o fim da investigação. (Dewey, 1960, p. 14)

Operações e instrumentos trabalham cooperativamente na investigação. O método da investigação consiste de operações realizadas ou a realizar e as formas lógicas são condições a serem satisfeitas durante a investigação. Há dois tipos de operações: as que se realizam em condições existenciais, ou seja, atuam sobre e com o material existencial. O caso da observação experimental ilustra esta situação; um exemplo seria a medição de um terreno. $\mathrm{O}$ outro tipo de operação é a que lida com e sobre os símbolos, sendo que as conclusões das operações simbólicas resultam em operações que atuam com existências. As operações compreendem tanto os materiais quanto os instrumentos, incluindo neste grupo as ferramentas e técnicas. O aperfeiçoamento destes implica num melhor desempenho das operações: "Quanto mais os materiais e instrumentalidades forem ajustados de antemão com vistas a aumentar a cooperação entre si como meios para se obter conseqüências, melhor serão controladas as operações que se realizam". (Dewey, 1960, p. 15) As operações da investigação poderão se deter no aprimoramento do seu objeto de forma a permitir a aplicação dos conceitos como modos operativos e, desta forma, desenvolver estruturas conceituais que 
sejam aplicáveis às condições existenciais. Fazendo referência ao que acontece nas artes técnicas e industriais, Dewey destaca o duplo movimento da teoria lógica.

[...] ambos movimentos têm lugar em estreita correspondência mútua, as concepções empregadas devem ser entendidas como diretamente operativas, enquanto que o material existencial, na medida em que as condições da investigação são satisfeitas, é determinado duplamente: pelas operações e com um olhar para as operações ainda a serem executadas. (Dewey, 1960, p. 16)

As formas lógicas são, por sua vez, condições a serem satisfeitas durante a investigação para se transformarem em asserções garantidas, como conseqüência das operações da investigação. Elas têm o status de postulados, diz Dewey: “elas são intrinsecamente postulados da e para a investigação, sendo formulação das condições, descobertas no curso da própria investigação.” (Dewey, 1960, p. 16) Os postulados seguem também o caráter progressivo e operacional da investigação. Por isso, eles alteram da mesma forma como os métodos são aperfeiçoados. Dewey rompe completamente com as concepções que tomam as formas lógicas como postulados a priori e reveladas pela razão pura.

A lógica é para Dewey uma teoria naturalista: as operações racionais nascem e se desenvolvem a partir das atividades orgânicas. Além disso, estabelece o princípio de continuidade das atividades de formas inferiores ou menos complexas às superiores, ou mais complexas. Assim posto, exclui a redução do superior ao inferior e a existência de hiatos entre eles. Este é um postulado da lógica deweyana. Por um lado, continuidade significa que exclui completamente a ruptura entre as operações da investigação e as operações biológicas e físicas. Continuidade exclui também toda repetição de identidades. Por outro lado, as operações racionais emergem das atividades orgânicas sem ser idênticas a elas. As funções e estruturas biológicas preparam o caminho para a investigação. Continuidade exclui, portanto, explicações que introduzem forças estranhas, totalmente novas, como força ou causa das mudanças. Exclui a introdução de conceitos derivados de um poder ou faculdades místicas, como a razão ou intuição pura, para explicar os processos lógicos

O significado de continuidade somente pode ser explicado tomando como referência o crescimento e desenvolvimento de qualquer organismo vivo, desde o seu estado germinal até sua maturidade. Os seres vivos adaptam meios para conseguir conseqüências, tanto de forma ordinária ou natural em seu viver, quanto de forma deliberada. Esta forma tende a se liberar das limitações das circunstâncias especiais pelos processos de generalização. A lógica resulta do processo de observação dos processos da investigação, sendo naturalista também neste aspecto. 
Seus conceitos estão abertos à inspeção pública, à observação e à verificação. Por isso, a lógica é uma disciplina social. Ela emerge no bojo da cultura e por ser forma continuada da reflexão, que surge como forma de resolver os problemas, ela modifica as condições culturais e sociais de onde surge: “o homem é naturalmente um ser que vive em associação com outros em comunidade, que possui linguagem e, por isso, aprecia a cultura transmitida. Investigação é um modo de atividade que é socialmente condicionada e tem conseqüências culturais.” (Dewey, 1960, p. 19) Linguagem compreende o conjunto de meios de comunicação - artes formalizadas como a língua, ritos, monumentos, etc. A linguagem é o meio pelo qual a cultura existe, é transmitida e tratada publicamente. Assim, para Dewey, a concepção naturalista da lógica significa dizer que ela é um naturalismo cultural:

A concepção naturalista da lógica, que serve de base à posição por nós adotada, é, por conseguinte um naturalismo cultural. Nem a investigação, nem a série mais abstratamente formal de símbolos pode escapar da matriz na qual eles vivem, movem e se desenvolvem. (Dewey, 1960, p. 20)

Da conexão que Dewey estabelece entre a investigação e a lógica, resulta que esta é compreendida de forma empírica, ou seja, distinta da mera especulação e de concepção $a$ priori ou intuitiva.

Dewey levanta uma dificuldade que afeta tanto a conduta orgânica, aquela orientada pelos hábitos, quanto a investigação deliberada. Trata-se da dificuldade de lidar com a permanente discrepância que existe entre os meios empregados e as consequiências resultantes. Os meios envolvem os órgãos, os hábitos e as concepções empregados na investigação deliberada e que se colocam na condição de presente e atuais. Eles são resultados das experiências passadas e operam com eficiência em duas condições: quando há semelhança das condições ambientais atuais com as que formaram os hábitos e quando os hábitos são flexíveis e se readaptam às novas condições. Porém, Dewey alerta que a tendência dos hábitos é de exercer sua força inercial e o fato de render-se a ela faz com que o ser humano viva num nível próximo do animal. A forma descoberta para se evitar a escravidão dos hábitos é a que reconhece a natureza provisional e condicional dos fatos implicados e a natureza hipotética dos conceitos e teorias. Isto porque as consequiências a serem alcançadas no processo de investigação são futuras. Por isso, Dewey reconhece a necessidade da máxima da prudência de Peirce chamada 'falibilismo', aplicada à investigação da investigação:

Resulta necessariamente da possibilidade e probabilidade de uma discrepância entre meios disponíveis e consequiências resultantes: entre condições passadas e futuras; e não da mera fragilidade dos poderes dos 
mortais. Porque nós vivemos em um mundo em processo, o futuro, embora contínuo com o passado, não é mera repetição. (Dewey, 1960, p. 40)

Sendo os conceitos uma relação de meio e conseqüência, podemos afirmar que eles estão sujeitos ao princípio do falibilismo.

\subsection{Conceitos como representações na linguagem}

A questão que estamos perseguindo busca compreender o processo de transformação das atividades animais em conduta inteligente, conceitual ou simbólica. O princípio de que Dewey parte é o do comportamento associado, presumidamente presente em toda a natureza. O estudo da relação entre o comportamento associado e a dimensão social dos conceitos ou significações trabalharemos no próximo capítulo. Anteciparemos aqui a idéia deweyana que compreende a emergência da linguagem, a partir do desenvolvimento das atividades associadas do ser humano, tornando o comportamento dotado de propriedade intelectual ou representativa. Diz Dewey:

O comportamento associado não caracteriza somente plantas e animais, mas elétrons, átomos e moléculas; e, pelo que conhecemos, todas as coisas que existem na natureza. A linguagem não originou a associação, mas quando surgiu como emergência natural de formas prévias de atividade animal, repercutiu transformando as formas e modos de comportamento associado prévios de tal maneira que acrescentou uma dimensão à experiência. (Dewey, 1960, p. 56)

Esta nova dimensão, em sentido amplo, é a cultura, segundo Dewey. Ela é tanto condição como produto da linguagem. O ambiente cultural, ao atuar modificando a conduta orgânica, dota esta de propriedades intelectuais. O desenvolvimento da linguagem neste ambiente cultural é a chave para compreender esta transformação da conduta humana. Dewey coloca da seguinte forma esta questão:

A transformação do comportamento orgânico em comportamento intelectual, caracterizado por propriedades lógicas, é produto do fato de que os indivíduos vivem em um ambiente cultural. Este viver os força a assumir em seu comportamento o ponto de vista dos costumes, crenças, instituições, significados e projetos que são pelo menos relativamente gerais e objetivos. [...] A linguagem ocupa um lugar destacado e exerce uma função peculiarmente significativa no complexo que forma o ambiente cultural. Ela é em si mesma uma instituição cultural. [...] Ela é (1) a agência através da qual outras instituições e hábitos são transmitidos, e (2) ela permeia tanto as formas como os conteúdos de todas as demais atividades culturais. Além disso, ela tem a sua própria e distintiva estrutura que pode ser abstraída como uma forma. (Dewey, 1960, p. 45) 
Dewey toma a linguagem num sentido abrangente, não se restringindo à linguagem oral ou escrita. Inclui também os gestos, ritos, cerimônias, monumentos, produtos de belas artes e da indústria. Os instrumentos, ferramentas, utensílios, máquinas, são, para Dewey, mais do que objetos físicos, simples ou complexo, com suas próprias qualidades e efeitos físicos, são também um modo de linguagem. Em termos gerais, Dewey entende a linguagem tem uma existência física: ela comporta objetos citados anteriormente, e, também, o conjunto de sinais e símbolos empregados de forma oral ou escrita. Entretanto, elas operam em função da capacidade representativa. "A linguagem é feita de existências físicas: sons, sinais no papel, ou um templo, estátua, ou tear. Mas estes não operam ou funcionam meramente como coisas físicas, quando eles são meios de comunicação. Operam em virtude de sua capacidade representativa ou de sentido.” (Dewey, 1960 p. 46)

A idéia da operatividade representativa da linguagem é, para Dewey, desenvolvida através da conexão entre os seguintes pares de termos: sinal e significação e símbolo e sentido. (cf. Dewey, 1960 p. 52) Estes termos designam duas classes diferentes de capacidade representativa. O termo símbolo tem, para Dewey, o sentido de ser "sinônimo de uma palavra como palavra, isto é, como um sentido carregado pela linguagem em um sistema, seja tal sistema de tipo solto ou intelectualmente rigoroso." (Dewey, 1960, p. 51) O termo símbolo é um meio que permite distinguir o que é designado por ele em uma ação conjunta e o que é frequentemente designado por sinais. Os símbolos são "sinais artificiais" e são distintos dos "sinais naturais". A palavra fumar, por exemplo, enquanto símbolo, depende de um acordo social em uso e, por isso, tem diferentes vocábulos conforme cada língua. Entretanto, se fumar for evidência da existência real de fogo, então é um sinal natural do fogo. Isto significa dizer que sinal refere-se, em sua a capacidade representativa, a coisas em suas relações recíprocas. "Para os propósitos da teoria, o que importa considerar é que as coisas existentes, como sinais, são evidências de outra coisa, neste momento inferida, mais que observada." (Dewey, 1960, p. 52) A função representativa do símbolo é outorgada por acordo social; a do sinal é por uma condição espaço-temporal. O que se torna relevante nesta distinção diz Dewey é a possibilidade de um livre e independente desenvolvimento dos sentidos com a instituição dos símbolos:

o sentido incorporado numa existência indiferente e neutra é liberado com respeito a sua função representativa. Não se encontra mais amarrado. Eles podem ser relacionados a outros 'sentidos' no sistema lingüístico; não somente ao de fogo [no caso da palavra fumar], mas a outros sentidos aparentemente pouco relacionados como fricção, mudanças de temperatura, 
oxigênio, constituição molecular, e, mediante símbolos-sentidos intermediários, às leis da termodinâmica. (Dewey, 1960 p. 52)

Como veículo, a significação, isolada e fixada num símbolo, subsiste quando a coisa desaparece, permitindo um discurso ordenado. Poderá ser usada em novo contexto ou situação, isto é, pode ser transferida, reaplicada, utilizando-se do passado para julgar e inferir o novo, constituindo assim, a chave de todos os juízos e inferências. Dessa forma, é possível um crescimento cumulativo da inteligência, na qual a experiência passada é um lastro para antecipar e regular uma nova experiência. A experiência adquire uma dimensão intelectual. Assim, o pensamento se habitua, ao empregar a linguagem, a utilizar, sem consciência explícita, as "sistematizações intelectuais da raça” (Dewey, 1979a, p. 232), isto é, as classificações, as distinções, os agrupamentos lógicos.

Pela comunicação, os acontecimentos são reconsiderados, revisados, readaptados, transformados em objetos ou coisas com significados, atendendo às exigências da conversação, tanto em nível de discurso do pensamento internalizado, quanto público. Os acontecimentos nomeados adquirem vida dupla e independente de espaço, tempo e contexto. As significações podem ser levadas ao plano ideal da experimentação interna, onde pensamento e imaginação fazem infinitas combinações e elaborações lógicas.

Onde existe a comunicação, as coisas ao adquirem significado, adquirem da mesma forma representantes, substitutivos, ou seja, símbolos e implicam outras que são infinitamente mais susceptíveis de manejo, mais estáveis e mais adaptáveis que os acontecimentos em seu primeiro estado. As coisas ganham um incremento novo e adquirem importância ao se tornarem representativas e se transformam adquirindo a "dignidade de uma função". (Dewey, 1958, p. 167)

O hábito de raciocinar com símbolos, uma vez instituído, pode ser desenvolvido por si mesmo indefinidamente. Quando ocorre o desenvolvimento ordenado dos sentidos entre si, algumas condições lógicas implícitas se tornaram explícitas, dando origem a algum tipo de teoria lógica.

Os símbolos introduzem uma nova dimensão, que permite o discurso ordenado e o raciocínio. Eles oferecem maior capacidade de manejo tornando possível tratar as idéias como idéias e as hipóteses como hipóteses. A partir desta diferenciação, Dewey introduz a idéia de inferência e implicação: "Do mesmo modo que a relação sinal-significado define a inferência, a relação dos sentidos que constituem as proposições define a implicação no discurso, se ele satisfaz as condições intelectuais para as quais é instituído.” (Dewey, 1960, p. 54, itálico do autor). Os trios podem ser assim colocados: A relação sinal-significado define a inferência, 
enquanto a relação símbolo-sentido define a implicação. Sinais e símbolos têm em comum o fato de serem eventos existenciais. Palavras como fumar escrever, falar, etc. são coisas físicas particulares e funcionam como universais no discurso. As coisas existentes, enquanto sinais, são evidência de outras coisas constituindo a inferência e não a observação. Palavras ou símbolos não são evidência de qualquer existência. Criam outra dimensão que é o discurso ou raciocínio. Portanto, para Dewey, a inferência e a implicação são duas coisas diferentes. A identificação de uma coisa com a outra deu origem à concepção da lógica como algo puramente formal, onde os sentidos estão relacionados reciprocamente, independente da referência existencial.

Encontramos no estudo que D. A. Piatt faz da lógica desenvolvida por Dewey uma sistematização de grande valor para nossa pesquisa. Apresentamos este estudo sobre os diferentes tipos de significação em Dewey a seguir:

A primeira classe de sentidos são intrínsecos aos eventos naturais, como experienciados. São qualidades dadas na experiência imediata e diretamente, tanto pré quanto pós analítica. No primeiro caso, são significados dados nas coisas antes de serem tomados na linguagem ou pensamento; no segundo caso, temos os objetos de conhecimento passado, que estão tão estabelecidos com um significado implícito que não vem ao pensamento.

Segunda classe de significação, que se origina da relação sinal-signficado, é proporcionada pela inferência. Estas significações são extrínsecas ou instrumentais. São dois os casos de significado extrínseco: Num caso simples, a situação em que uma coisa sugere a outra, leva-nos a esperar a outra sem instigar reflexão ou investigação. Num caso complexo, a inferência de um caso para o outro é explicitada através da investigação. Passamos de um objeto ao outro por meio de símbolos ou idéias intermediárias, por exemplo, de uma nuvem à chuva. Embora os símbolos — sentidos sejam importantes, eles são intermediários, pensamos com eles e não pensamos sobre eles. Nas palavras de Dewey, "O que a coisa significa é uma outra coisa; ela não significa um significado.” (Brock University, 2007) .Terceira classe é composta pelos sentidos simbólicos, adquiridos e usados nas operações da linguagem no desenvolvimento de implicações. Tem relação funcional entre a coisa como sinal e as outras coisas como significados. A significação é uma idéia, um gesto, um símbolo como substituto para o que é existencialmente indicado. Apontam para duas direções: são significados do pensamento no seu próprio meio de linguagem, mas eles se referem ou devem se referir a acontecimentos existenciais. Idéias e símbolos significam coisas somente no sentido de se referirem ou se aplicarem às coisas através da observação de um experimento com 
acontecimento existencial. São símbolos-sentidos que implicam outros símbolos-sentidos e pelo raciocínio elaboramos e clarificamos as implicações ou significados de uma hipótese. (Cf. Piatt, 1939, p. 122-124)

Dewey se ocupa de esclarecer o sentido da palavra relação na sua teoria lógica. Por um lado, reconhece a ambigüidade desta palavra, que pode criar confusão teórica. Assim, a palavra relação é utilizada para abarcar as seguintes coisas: a relação direta dos símbolos entre si, a sua relação com as existências pela mediação das operações existenciais e, ainda, a relação das existências entre si na função da evidência sinal—significado. Por outro lado, ele esclarece a natureza lógica dos diferentes objetos:

[...] reservarei a palavra relação para designar o tipo de relação que guardam entre si os símbolos-sentidos como tais; usarei o termo referência para designar o tipo de relação que mantêm com a existência; e as palavras conexão (e complicação) para designar este tipo de relação que guardam as coisas entre si, em virtude da qual a inferência é possível. (Dewey, 1960, p. 55)

As relações dos significados instituídas no discurso somente fazem sentido se percebidas no seu transcurso histórico. As coisas não seriam tratadas como sinais se não fossem os símbolos que permitem reter as qualidades das coisas pela inferência. As palavras e símbolos permitem discriminar e manter as qualidades experiênciadas das coisas. Assim, a linguagem origina um meio de comunicação que torna possível a deliberação cooperativa e as atividades compartilhadas.

A filosofia moderna tem se ocupado com o problema da existência, como determinada perceptiva e conceitualmente, ou entre outra relação muito estreita com esta que é a diferença entre um objeto e uma situação. (Dewey,1960, p. 66)

A crítica de Dewey dirige-se à lógica formal. Esta lógica, concebida por Aristóteles, está baseada no silogismo como forma de ordenar os conceitos de acordo com as subordinações implícitas definidas como essências e espécies, tal como se encontram hierarquicamente na natureza. As classes ou espécies aristotélicas são compreendidas na sua condição ontológica. Somente as essências podem ser conhecidas uma vez que são permanentes e universais e funcionam como o "motor imóvel" do pensamento. A definição nada mais é do que a captação cognoscitiva que delimita a essência da substância em seu caráter eterno. As mudanças são incognoscíveis e, por isso, desconsideradas de valor lógico. Extraímos o excerto a seguir que sintetiza a posição deweyana em relação à lógica e à concepção aristotélica: 
Em primeiro lugar, as formas reconhecidas não são formalistas. Elas não são independentes dos "sujeitos" conhecidos. Pelo contrário, representam as formas de tais sujeitos na medida em que estes últimos se encontram atualizados no conhecimento. Em segundo lugar, o conhecimento, em suas formas lógicas, consiste exclusivamente de definições e classificações. Nenhum destes processos é verbal, psicológico, nem sequer uma ajuda apara a reflexão. A definição capta a essência que faz com que as coisas sejam o que são realmente. A classificação se refere às exclusões e inclusões ontológicas das espécies naturais reais. A definição e a classificação taxionômica são formas necessárias do conhecimento porque são expressões das formas necessárias do Ser. Em terceiro lugar, não há espaço algum para uma lógica da descoberta e invenção. (Dewey, 1960, p. 87)

Na obra $O$ conhecer e o conhecido, ao tratar da definição sobre as questões $o$ que $a$ coisa é e o que uma palavra diz, Dewey retoma sua análise da forma como Aristóteles pensou a definição. Nesta análise, Dewey acrescenta que, além da definição expressar as essências, ela deve expressar também o processo de encontrá-las. As espécies foram delimitadas através das formas que as fazem ser o que são. Acrescenta: "foi na forma de discurso (logos) que a lógica e a ontologia entraram em perfeito acordo.” (Dewey, 199b, p. 157/158)

A crítica deweyana à lógica formal aristotélica tem um forte cunho histórico-cultural, social e psicológico. Dewey considera que a lógica aristotélica é um documento histórico admirável: ela representa uma "formulação organizada da linguagem da vida grega, quando se considerava essa linguagem como expressão dos sentidos da cultura grega e do significado atribuído às várias formas da existência natural." (Dewey, 1960, p. 101) A crítica direciona-se à tentativa de manter essa lógica fazendo revisões e adições para adequá-la para a ciência atual. Neste caso, não se reconhece que a lógica formal é perfeita e adequada para a estrutura de classe da cultura grega. Trata-se de uma formulação parcial, também, pelos recursos disponíveis naquele contexto. Dewey eleva o tom de sua crítica ao ponderar a forma como os autores da lógica clássica trataram os instrumentos:

[...] não reconheceram que os instrumentos constituem uma classe de linguagem que se encontra em uma conexão mais compulsiva com as coisas da natureza do que estão as palavras, nem, tampouco que a sintaxe das operações fornece um modelo para o esquema do conhecimento ordenado mais exato do que a linguagem falada ou escrita. (Dewey, 1960, p. 94)

Rompendo com a concepção grega, o conhecimento da ciência moderna se ocupa de estudar as correlações entre as mudanças e introduz em seus procedimentos e propósitos os instrumentos e procedimentos dos trabalhadores produtivos. Temos, assim, uma substituição da relação matéria e forma grega para a matéria e movimento na ciência moderna. A revolução científica significa uma posição completamente diferente substituindo os aspectos qualitativos, heterogêneos, permanentes (formais) e dependentes (exclusão e inclusão), pelos 
aspectos quantitativos, homogêneos, teleologicamente abertos e relacionados como base para a investigação. Subjacente a estas distinções está a mudança no conceito de natureza, conforme explica Dewey:

A mudança na concepção de Natureza se expressa, de forma sumária, com a idéia de que agora o universo é concebido como aberto e em processo, enquanto que o pensamento clássico grego o concebia como finito no sentido de que finito significa definido, completo e perfeito. $O$ infinito era, na ciência grega, o indefinido, e como tal, não podia ser conhecido. (Dewey, 1960, p. 93)

A lógica consistirá numa descrição analítica dos métodos científicos, o modo que trabalhamos, quando investigamos com rigor. A lógica é a teoria da investigação ou investigação da investigação, ou, ainda, a reflexão sobre os juízos de assertibilidade garantida. Dewey identifica a assertibilidade garantida com o contínuo da investigação em marcha. A lógica é uma ciência autônoma, pois não está comprometida com nenhum conceito metafísico ou epistemológico.

Dewey polemiza com a formulação kantiana do conceito de conhecimento. Kant concebe o juízo como a relação da percepção com a conceptualização, como forma de contemplar a reivindicação das duas concepções opostas: o empirismo e o racionalismo. Assim, Kant atribuiu superioridade à razão e mesmo um poder auto-suficiente para dar significado à vida humana, conseqüentemente negligenciando a experiência. $\mathrm{O}$ critério de validade do conhecimento para Dewey, conforme vimos, é a ação:

A solução que é sempre procurada e nunca encontrada sempre que tratamos o conhecimento como um auto-suficiente fornecedor de realidade, revela-se quando nós concebemos o conhecimento como uma regra da ação, tal regra como sendo necessária, além disso, para o progresso bem sucedido da ação. [...] O conhecimento pode definir a percepção e elaborar o conceito, mas sua união pode ser encontrada somente na ação. $\mathrm{O}$ método experimental da moderna ciência, sua instituição dentro do modo de verificação final, é simplesmente este fato obtendo reconhecimento. Somente a ação pode reconciliar o velho, o geral e o permanente com a mudança, o indivíduo e o novo. [...] Assim, começa uma nova cadência no ritmo da teoria e da prática. (Dewey, 1965, p. 299-300)

Desta forma, Dewey concebe que conhecer e formar um conceito é um mesmo processo, e portanto, a percepção e a concepção não são atividades distintas. Ambas estão influenciadas pelo contexto da ação, que se expressa individualmente como experiência. A crítica deweyana dirige-se também ao dualismo sujeito e objeto, na forma como a epistemologia e ontologia têm adotado como base para formular o conhecimento. O dualismo sujeito-objeto segmenta a experiência, que para Dewey é um continuum: 
"Na experiência real nunca existe semelhante objeto ou evento singular isolado; um objeto ou acontecimento é sempre uma parte, fase ou aspecto especial de um mundo circundante experienciado - uma situação. $\mathrm{O}$ objeto singular aparece destacadamente por causa da sua posição particularmente focal e decisiva em determinado momento, na determinação de algum problema de uso e gozo que o complexo total de circunstâncias apresenta. Há sempre um campo no qual ocorre a observação deste ou daquele objeto ou evento. A observação destes é feita com o objetivo de averiguar o que o campo é com referência a alguma resposta ativa adaptativa a ser efetivada, através do prosseguimento de um curso de comportamento. (Dewey, 1960, p. 67 , itálicos do autor)

O ato e objeto da percepção têm lugar e função específica que é o de promover e dirigir com sucesso o curso da ação. Quando o ato e objeto são isolados, eles passam a ser considerados como se estivessem exclusivamente na condição de cognitivos. Eles são objetos notados e discriminados como objetos de conhecimento, mas não no sentido definitivo e autosuficiente. São objetos de conhecimento discriminadamente notados, no sentido de serem guia para a conduta, ou seja, são usados com sucesso na situação da qual emergiram de forma a resultar em uso e gozo ou evitar o sofrimento. Não se trata de conhecer o objeto enquanto tal, mas de precisar o seu significado para lidar com a situação como um todo. Diz Dewey: "Vivemos e atuamos em conexão com o ambiente existente e não em conexão com objetos isolados, ainda que uma coisa singular possa ser crucialmente significativa na decisão de como responder ao ambiente total." (Dewey, 1960, p. 68)

\subsection{Experiência, situação e investigação}

O ambiente total é, para Dewey, a situação. Sua posição se diferencia da forma como a filosofia moderna trata a existência sob a percepção e concepção de objeto. Para Dewey, situação, considera a começar pelo sentido negativo, é a seguinte:

"não designa um objeto ou evento singular, ou um conjunto de objetos ou eventos isolados. Pois, nunca experimentamos nem formamos juízos sobre objetos ou eventos isoladamente, mas apenas em conexão com todo contextual. Este último é que é chamado de uma situação. (Dewey, 1960, p. 66)

O todo contextual é a qualidade que impregna situação. Trataremos do termo qualidade posteriormente. A totalidade, questão a ser tratada agora, é uma qualidade que junta todos os elementos da situação e, também, torna-a única, individual, indivisível e induplicável. (cf. Dewey, 1960, p. 68) Psicologicamente, este todo contextual, que é a situação é sentido, mas, continua Dewey, apenas de modo negativo, ou seja, de não ser sob a 
forma de um discurso racional. O sentir, as emoções, as sensações somente podem se descritas ou identificadas em função da presença de uma situação qualitativa em sua totalidade. Distinções e relações são feitas no interior da situação e são recorrentes e repetíveis. O discurso, para ter sentido, precisa sempre da referência controladora de uma situação que determina a importância, peso e coerência das distinções e relações que se estabelecem. Dewey torna mais precisa a relação do discurso com a experiência: "Um universo de experiência é condição prévia de um universo de discurso. [...] O universo da experiência circunda e regula o universo do discurso, mas nunca aparece como tal dentro deste." (Dewey, 1960, p. 68) Falar sobre o universo da experiência e situações significa introduzi-los dentro do domínio de símbolos. Assim, por princípio, um termo ou elemento do discurso em si mesmo não constitui um universo de discurso. O universo do discurso é constituído como "um termo de discurso dentro de outro universo". (Dewey, 1960, p. 69) O universo da experiência não foge deste princípio. Não é possível demonstrar universos de experiência por meio do discurso. Sempre temos uma situação experienciada, caso contrário, não teríamos experiência. Pelo discurso, pode-se obter uma situação imediatamente experienciada. A presença de uma situação qualitativa e qualificadora como fundo e controle do universo de cada experiência é condição de todo discurso. Por ela o discurso é circundado e regulado.

Analisemos o sentido dado por Dewey ao termo qualidade. A associação desta palavra com algo específico, como azul, duro, doce, etc. faz apenas uma distinção específica dentro da experiência total. O sentido que contrasta a este e que foi aludido anteriormente é o que toma a qualidade como algo que permeia e contém todos os objetos e eventos do universo da experiência. Como exemplos próximos deste critério, pode-se recorrer a qualidades terciárias, como penoso, perplexo, alegre, etc. Dewey menciona a expressão de Santayana de "qualidades terciárias", porque ela "qualifica a todos os elementos componentes aos quais se aplica de maneira absoluta." (Dewey, 1960, p. 69) Entretanto, não constitui um exemplo adequado uma vez que os termos, como os apresentados no exemplo, são gerais, enquanto que as qualidades - penosidade, alegria, etc. -, que estão presentes em uma situação e que a caracterizam, são únicas e não podem ser expressas por palavras.

Outra maneira de se aproximar do sentido de qualidade é o uso estético do termo. Pode-se dizer, por exemplo, que uma pintura tem a qualidade de um Ticiano ou Rembrandt. A referência não alude a uma linha, cor ou parte da pintura, mas a algo que afeta e modifica o seu conjunto. Mais do que uma palavra específica é algo que se deve ter como uma 
experiência imediata total. O discurso realça componentes, linhas, relações através dos quais se chega à qualidade que impregnam e unificam. Temos, então, um objeto de reflexão e não mais um objeto estético. Dewey reforça: "uma situação qualitativa e qualificadora está presente como fundo e controle de toda experiência." (Dewey, 1960, p. 70, itálico do autor) É a sensibilidade a esta qualidade que permite desentranhar o problema. Tanto o procedimento, que se ocupa de observar fatos amontoando-os sem se chegar a lugar algum, quanto as observações controladas por esquemas conceituais prévios e fixos, que forçam as situações para serem embutida neles mesmos são impeditivos à percepção da qualidade da situação. Conclui Dewey: “o problema deve ser sentido antes de ser determinado. Se a qualidade única da situação é dada imediatamente, então dispomos de algo que regula a seleção e o peso dos fatos observados e seu ordenamento conceptual." (Dewey, 1960, p. 70, itálicos do autor)

\subsection{O papel do conceito na pauta da investigação}

A questão que falta analisar é relação entre o conceito e a investigação: como Dewey compreende o papel dos conceitos na pauta da investigação?

Dewey depreende a pauta da investigação a partir da análise da própria experiência. As formas lógicas que compõem a pauta da investigação não são inventadas ad hoc, nem concebidas a priori. As formas lógicas se desenvolvem das operações que os homens estabelecem na experiência co-participada. Vejamos a exposição que Dewey faz:

Na medida em que determinados aspectos e fases destas transações são formalizadas legalmente, surgem concepções tais como má conduta, crime, danos, contratos, e assim por diante. Tais concepções formais surgem a partir das transações ordinárias, não são impostas a elas provindas das alturas ou de qualquer origem externa ou a priori. Mas, quando são formadas, tornam-se também formativas; regula a conduta adequada das atividades a partir da qual se desenvolveram. (Dewey, 1960, p. 102, itálico do autor)

As concepções são operacionais. Elas surgem no movimento transacional dentro da do campo da experiência, modificando-o e modificando a própria concepção continuamente. Portanto, não podem ser concebidas como formas fixas e eternas: "elas se origina a partir do material da experiência, e quando constituídas introduzem novos modos de operar com materiais antecedentes, modos que modificam o material, a partir do qual se desenvolvem." (Dewey, 1960, p. 103) Com este pressuposto, Dewey pretende liberar a teoria lógica daquelas pretensões de estabelecer as formas lógicas a partir do inobservável, do transcendente e do intuitivo. Desta forma, evita-se o dualismo entre o psicológico e lógico, entendendo, neste 
caso, o lógico como normas que prescrevem o como se deve pensar, fornecidas por fontes externas à experiência. A lógica é concebida a partir da observação sobre a maneira como os homens pensam. Isto significa dizer que os métodos empregados na experiência são considerados e reconsiderados em função dos resultados, podendo fornecer normas ou modelos para conduzir novas experiências. Estas normas e modelos passam a ser considerados os melhores métodos, ou seja, a maneira como se deveria proceder. Entretanto, o fato de se revelarem os melhores métodos não lhes garante o estatuto de ser idealmente perfeitos ou absolutos. Pesquisa dos modelos da investigação esta sujeita à própria investigação, é conferida e controlada pelas formas de investigação que mostram melhor ou pior funcionamento na experiência. Desta comparação dos métodos, conclusões fundamentais são produzidas. O modus operandi da lógica para Dewey:

através da comparação e do contraste, verificamos como e por que certos meios e instrumentalidades têm fornecido conclusões garantidamente assertíveis, enquanto que outros não o têm feito e não o podem fazê-lo no sentido em que "não podem" expressar uma incompatibilidade intrínseca entre os meios utilizados e as conseqüências alcançadas. (Dewey, 1960, p. 104 , itálico e aspas do autor)

A idéia de "asserção garantida" é fundamental para a lógica da investigação, pois, determina as exigências objetivas que os resultados devem satisfazer. Está ligada à noção de experiência enquanto integração do organismo com o meio, modificando este em função da sobrevivência do primeiro. A equação que Dewey desenvolve é a que mantém o processo interativo aberto ou contínuo: inicia com a situação problemática, restabelece a interação através de uma solução - asserção garantida - produz modificação e acúmulo que geram novos problemas.

A atividade vital supõe modificações tanto nas energias orgânicas quanto ambientais. O fato orgânico antecipa a aprendizagem e a descoberta, com a conseqüente emergência de novas necessidades e novas situações problemáticas. A investigação, ao restabelecer a situação de distúrbio entre organismo e ambiente (que define a dúvida) não se limita a remover a dúvida, recorrendo a uma integração adaptativa anterior. Estabelece novas condições ambientais que originam problemas novos. $\mathrm{O}$ que o organismo aprende neste processo produz novos poderes que fazem novas demandas sobre o ambiente. Em uma palavra, quando se resolvem problemas especiais, outros tendem a emergir. Não existe uma coisa como estabelecimento de solução final, porque todo estabelecimento introduz as condições de algum grau de indeterminação. Dewey, 1960, p. 35)

A investigação é uma atividade vital para a sobrevivência do homem. A investigação se faz necessária diante das situações problemáticas que surgem no curso da experiência. Assim, a lógica, como teoria da investigação controlada, não está limitada estritamente ao 
campo científico, ainda que extraia dele o modelo. Trata-se de estender as vantagens da lógica a todos os domínios da vida, a fim de garantir uma ação sensata, inteligente e mais eficiente. Dewey identifica a lógica, entendida como a investigação da investigação, com o pensamento refletivo. "Nós não sabemos qual o sentido há de se assinar à expressão 'pensamento reflexivo' exceto em termos do que é descoberto pela investigação da investigação." (Dewey, 1960, p. 21)

A investigação que se ocupa de resolver a situação problemática, Dewey chama também de pensamento reflexivo. O pensamento reflexivo, diferenciando-se de outras operações do pensamento, é caracterizado por duas fases complementares conforme concebe Dewey: “(1) um estado de dúvida, hesitação, perplexidade, dificuldade mental, o que origina o ato de pensar; e (2) um ato de pesquisa, procura, inquirição, para encontrar material que resolva a dúvida, assente e esclareça a perplexidade." (Dewey, 1979b, p. 22) A função do pensamento reflexivo é resolver a situação problemática. De acordo com a afirmação de Dewey, a função do pensamento reflexivo é: "transformar uma situação de obscuridade, dúvida, conflito, distúrbio de algum gênero, numa situação clara, coerente, assentada, harmoniosa." (Dewey, 1979a, p. 106, itálicos do autor). Pensamento reflexivo é a atividade inteligente que exige esforço consciente e voluntário que reconstrói as crenças através da investigação: "O pensamento reflexivo faz um ativo, prolongado e cuidadoso exame de toda crença ou espécie hipotética de conhecimento, exame efetuado à luz dos argumentos que a apóiam e das conclusões a que chega." (Dewey, 1979, p. 18, itálicos do autor) Dewey identifica a atividade de pensamento reflexivo como sendo a própria atividade da investigação, conforme podemos ver em sua definição de investigação: A investigação é $a$ transformação controlada ou dirigida de uma situação indeterminada em outra que é de tal modo determinada nas suas distinções e relações que a constituem que converte os elementos da situação original em um todo unificado. (Dewey, 1960, p. 104, itálicos do autor) A situação de indeterminação dá abertura à investigação, uma vez que as qualidades constituintes dela não se mantém unidas. Situação determinada através do curso da investigação é fechada e constitui um universo de experiência. É no curso intermediário que as concepções operam: "no curso intermediário de transição e transformação da situação indeterminada, o discurso, pelo uso de símbolos, é empregado como meio." (Dewey, 1960, p. 105) O núcleo da questão é compreender como Dewey concebe o papel dos conceitos nos cinco passos que compõem, como veremos a seguir, a pauta dos procedimentos da 
investigação, ou seja, o método do pensamento reflexivo ${ }^{26}$. Estas fases são divisões funcionais do trabalho da investigação.

\section{Primeira fase: A situação indeterminada.}

Dewey coloca esta fase como antecedente à investigação. Nesta situação a interação que o organismo vivo mantém com o ambiente depara-se com uma dificuldade, dúvida, perturbação, hesitação, conflito, perplexidade ou mesmo curiosidade. Há uma interrupção, suspensão, ruptura, ou conflito no fluxo da experiência. Trata-se de uma qualidade específica da situação que impregna os materiais dados, que passa a ter a qualidade de incerteza. Não se trata de uma indeterminação completa da situação. A indeterminação é dada na situação e não na observação. Isto quer dizer que a significação por meio da qual o organismo respondia ao meio passa a ser indeterminada com relação aos resultados. Situação incerta não é algo apenas subjetivo, na medida em que a interação se dá entre seres biológico-culturais. A situação é pré-cognitiva, mas é ativa e operacional, pois demanda do organismo o exame da situação e a antecipação de consequiências que resolvam o conflito.

\section{Segunda Fase: Formulação de um problema}

A situação é tomada como problemática e se delimita o problema, objeto de investigação. Sem o problema move-se na escuridão. O problema bem formulado é meio caminho andado. Por outro lado, o problema delimita o critério para a relevância dos processos investigativos:

O modo pelo qual o problema é concebido decide quais a sugestões específicas que serão tomadas em consideração e quais serão deixadas de lado; que dados serão selecionados e que dados serão rejeitados; ele é o critério de relevância ou de irrelevância das hipóteses e estruturas conceptuais. (Dewey, 1960, p. 108)

Assim, a atividade reflexiva instaura o problema através da indagação: perguntas, questionamentos que remontam à experiência anterior de confusão e perplexidade e às

\footnotetext{
${ }^{26}$ A pauta da investigação ou as fases do pensamento reflexivo foram estudadas com mais profundidade na dissertação de mestrado - Muraro. A dimensão do pensar na educação escolar: o pensamento reflexivo como princípio educativo em John Dewey, PUCSP, 1998.
} 
crenças, idéias que a sustentavam. O pensamento traz à mente inúmeras sugestões (significações familiares), que concorrem para harmonizar a situação.

\section{Terceira fase: a determinação da solução do problema.}

Num primeiro momento, através da observação, é necessário estabelecer os constituintes do problema. A observação dos fatos tem a finalidade de descrever e localizar o problema. Opera no âmbito existencial. Trata-se de estabelecer e determinar na existência espaço-temporal os elementos constituintes do problema. Nesse percurso de tempo, o objeto de investigação sofre modificação temporal. Num segundo momento, a investigação é alimentada com uma espécie de invasão de sugestões, mas elas são em si, ainda, vagas. Aparecem como estímulos para dirigir a atividade externa e não possuem ainda condição lógica. Uma sugestão transforma-se em idéia, diz Dewey, "quando é examinada com referência a sua aptidão funcional; a sua capacidade como meio para a resolução de uma situação dada. (Dewey, 1960, p. 110) As idéias referem-se a algo não presente na existência dada, mas significados incorporados em símbolos. Nesta condição podem ser inspecionados e desenvolvidos objetivamente. O objeto ideacional é não existencial. Temos assim, com os dados e idéias, os "fatos do caso". A investigação se ocupa de superar a simples sugestão e aceder às idéias que são soluções funcionais, graças à previsão e observação controlada. Esta etapa que opera com conteúdos ideacionais se caracteriza pela inferência: "Como a inferência vai além do presente atual, ela supõe um salto adiante, um salto no desconhecido." (Dewey, 1979a, p. 103)

Examinar uma idéia equivale a avaliar a pertinência e peso do seu significado em termos funcionais. Ela opera, no processo investigativo, tanto por meio da observação de novos fatos quanto na organização dos dados num todo coerente. No processo da investigação, a operação com as idéias pode mostrar sua inviabilidade como solução ou como possível solução do problema e, ainda, como reformulação do problema.

Neste ponto, Dewey chama a atenção para a forma como as teorias lógicas têm trabalhado com as sugestões. Os empiristas reduzem as sugestões a "cópias mentais das coisas físicas". Os racionalistas tomam as idéias como determinantes dos fatos. Apesar da agudeza 
lógica de Kant em sua síntese - "as percepções são cegas e os conceitos vazios ${ }^{27}$ - ele concebe os conteúdos perceptivos e conceptuais oriundos de fontes diferentes. Cabe ao entendimento sintético uni-los. A união se dá numa terceira atividade criada por Kant. A crítica de Dewey a estas posições decorrem do erro de compreender o fato lógico:

Os materiais perceptivos e conceptuais são instituídos em correlação funcional recíproca, de modo tal que os primeiros localizam e descrevem o problema, enquanto os últimos representam um método possível de solução. Ambos são determinações na e pela investigação da situação problemática original, cuja qualidade impregnante controla sua intuição e seus conteúdos. Ambos são finalmente provados por sua capacidade de trabalhar conjuntamente, a fim de estabelecer uma situação unificada solucionada. Enquanto distintos, representam divisões lógicas do trabalho. (Dewey, 1960, p. 110)

\section{Quarta fase: o raciocínio}

A investigação volta-se para a elaboração racional de uma idéia. Opera com símbolos constituindo as proposições de um discurso racional. Análise das implicações das idéias sugeridas, estabelecendo os elos entre a idéia e as conseqüências de possível aplicação. Aqui o exame é do significado enquanto significado. É a fase da implicação: "Este exame consiste em registrar-se o que implica o significado em questão, relativamente a outros significados no sistema do qual é membro, sendo que a relação, uma vez formulada, constitui uma proposição.” (Dewey, 1960, p. 111) O raciocínio opera com uma série de significados intermediários, até localizar o significado mais relevante para o problema, indicando as operações para testar sua aplicabilidade. São juízos intermediários que operam como estimativas ou avaliações sobre o material fático e estrutura conceptuais. Eles são meios para se alcançar o juízo que encerra a investigação e resolve a situação problemática. Não podem ser concebidos como conhecimento imediato.

Nesta fase a atividade reflexiva examina as relações entre o problema e a hipótese e cada um em particular, a partir dos dados que são tomados da situação e da própria memória. O raciocínio toma a hipótese e a desenvolve em relação a outras estruturas conceptuais

\footnotetext{
${ }^{27}$ Dewey fala em diversos momentos desta referência a Kant nas seguintes versões: "percepção sem concepção é cega, concepção sem percepção é vazia." (Dewey, 1965, p. 272) ou "sensação sem pensamento é cega, pensamento sem sensação é vazio." (Dewey, 1965, p. 296)
} 
desenvolvendo uma forma de conduzir um experimento. $\mathrm{O}$ experimento revela as condições que têm força para que a hipótese seja aceita ou recusada.

\section{Quinta fase: a verificação experimental}

Verificação da hipótese, submetendo-a à prova. Se houver coincidência de resultados experimentais com resultados teóricos chega-se, assim, à conclusão. Na verificação experimental a idéia / hipótese opera em uma ação externa para se verificar os resultados; se a situação se transformar, tornando-se clara, coerente, harmoniosa, determinada teremos uma significação padronizada (generalizada), que encerra a atividade reflexiva. Terá o caráter de "asserção garantida". Trata-se de um juízo, uma decisão final, uma conclusão que satisfaz e encerra a investigação. A investigação termina instituindo as condições que removem a dúvida. Este estado final pode ser designado por crença, conhecimento ou na expressão preferida por Dewey, "asserção garantida."

A investigação tem caráter temporal e é progressiva e contínua. Continuidade porque as conclusões de uma investigação servem de meios, materiais e procedimentos para conduzir investigações futuras. Não se deve confundir o uso deste material como conhecimento imediato, já que todo conhecimento é, para Dewey, mediato: “Todo conhecimento, enquanto asserção fundamentada, envolve mediação. Mediação, neste contexto, significa que em toda asserção garantida está envolvida uma função de inferência. (Dewey, 1960, 120)

$\mathrm{O}$ ato de pensar conduzido desta forma se torna uma experiência reflexiva contínua, consecutiva e conseqüiente. A conclusão encerra sempre um risco, diz Dewey, pois não se pode garantir antecipadamente a certeza quando se penetra no desconhecido: "As conclusões da reflexão, até que os acontecimentos confirmem, são, por conseqüência, mais ou menos tateantes, ou hipotéticas." (Dewey, 1979a, p. 162)

Asserção garantida é fase em que o conceito adquire plenamente uma significação por responder a uma situação confusa. A assertividade garantida pode ser entendida como o verdadeiro no sentido de útil. Embora resultando em um conhecimento, este conhecimento está subordinado ao seu uso no ato do pensar. Tem caráter provisório, assim como a situação é provisória e fonte de novos problemas. Dewey se expressa da seguinte maneira: "não vivemos num mundo fixo e acabado, e sim, em um mundo que evolui e onde nossa principal tarefa é a visão prospectiva, onde a visão retrospectiva - todo conhecimento como coisa 
distinta da reflexão é retrospectivo - tem valor na proporção da solidez segurança e fecundidade do que garante nossos negócios no futuro.” (Dewey, 1979b, p. 166)

Dewey retoma a discussão da verdade a partir da lógica experimental e funcional na obra Reconstruction on Philosophy. Ele amplia essa discussão sobre a natureza pragmática da verdade, a partir da noção de utilidade em contraposição à verdade como algo fixo, preestabelecido como propriedades estáticas das coisas. A verdade é um "corolário da natureza do pensamento e das idéias" e justifica da seguinte forma: "Se idéias, concepções, noções, teorias e sistemas são coisas instrumentais a uma ativa reorganização do meio, a uma remoção de alguma dificuldade ou perplexidade, então a prova de sua validade e valor repousa no cumprimento de tal tarefa." (Dewey, 1959a, p. 159). O cumprimento desta tarefa será verdadeiro ou falso conforme confirmem, corroborem, verifiquem ou não uma concepção ou hipótese. A verdade somente pode ser conhecida pelos seus frutos, isto é, pelos resultados, realizações, obras. Este é o guia da verdade. Por isso, diz Dewey "O advérbio 'verdadeiramente' é algo mais fundamental do que o adjetivo 'verdadeiro' ou do que o substantivo 'verdade', pois, como todos os advérbios, expressa um modo, uma forma de agir." (Dewey, 1959a, p. 159). A noção de verdade está intimamente conectada com a concepção. Diz Dewey que

\footnotetext{
"a concepção não é outra coisa senão uma reivindicação, uma exigência ou ordem, um plano de agir de determinado modo, modo este pelo qual se dissipa uma situação embaraçosa. Quando a exigência, ou pretensão ou plano é posto em execução, nós seremos guiados verdadeiramente ou falsamente, seremos conduzidos ao nosso ou dele nos afastaremos. Sua função ativa, dinâmica, é tudo o que nela há de importante, e na qualidade de atividade a que ela induz reside toda sua verdade, quando não sua falsidade. A verdadeira hipótese é a que surte bons efeitos, é a da verdade. (Dewey, 1959a, p. 159).
}

Dewey esclarece que às vezes a verdade é tomada no sentido de satisfação emocional ou conforto. Se entendida como satisfação, há que se resguardar o sentido no que está expresso na citação que acabamos de mencionar. E da mesma forma, o sentido da verdade como utilidade: "significa assistência no prestar aquele tipo de contribuição à reorganização da experiência que a idéia ou teoria reclamam ser capazes de prestar." (Dewey, 1959a, p. $160)$.

Dewey faz um radical deslocamento do conceito da verdade e da concepção e as consequiências políticas que decorrem. Por um lado, diz Dewey a verdade foi identificada como o dogma autoritário, pautado num corpo de verdades fixas e superiores, condizente com uma sociedade organizada em torno da ordem e que evita o crescimento e a mudança por 
serem coisas desestabilizadoras. Esta sociedade se apóia no passado, diz Dewey "olha para trás, para alguma coisa já existente, como fonte e sanção da verdade, há de recorrer ao que é antecedente, prévio, original, a priori, a fim de conseguir segurança.” (Dewey, 1959a, p. 161). Por outro lado, a concepção pragmática da verdade e da concepção, impõe um olhar para frente:

$\mathrm{O}$ pensamento voltado para a frente, em direção ao eventual, às conseqüências, origina desconforto e receio, perturba o senso de quietude que é ligado às idéias de verdade fixa com existência antecipada, além de nos colocar um pesado fardo de responsabilidade sobre os ombros da procura, pela observação perseverante, pelo escrupuloso desenvolvimento de hipóteses e provas exaustivas. [...] Enquanto, através de palavras se estabelece o lugar-comum o fato de que as definições hão necessariamente de originar-se de casos específicos e concretos, ao invés de serem inventados no espaço vazio e impostas aos particulares, há uma estranha má vontade de agir de acordo com o mencionado lugar-comum referente à definição de verdade. Divulgar o reconhecimento de que o verdadeiro significa tão-só o verificado e nada mais, equivale a colocar sobre os ombros dos homens a responsabilidade pela renúncia a dogmas políticos e morais, bem como a submeter à prova das conseqüências, até mesmo os seus mais caros preconceitos. Tal mudança compreende grande alteração na sede da autoridade, bem como nos métodos de decisão na sociedade. (Dewey, 1959a, p. 161-162).

\section{4. $O$ conceito e seus elementos}

A atividade reflexiva se encerra na verificação de critérios pelos quais a investigação compartilhada numa relação social valida a nova crença e permite a elaboração de uma asserção garantida. Esta operação do pensamento reconstitui a relação organismo e meio ao resolver o problema, torna harmoniosa uma determinada situação. Neste processo, uma idéia foi tomada como guia para as observações e para a ação, e confirmada em sua significação como solução do problema. Adquire um novo status que é o de ser "significação padronizada" ou "padrões de referência" ou uma concepção: "Estes significados estabelecidos, tidos como certos e garantidos, são as concepções.” Elas poderão ser empregadas com segurança como “instrumento de compreensão e de explicação das coisas ainda incertas e confusas", ou ainda, meios de julgamento. (Dewey, 1979a. p. 151) Para ser mais específico, Dewey compreende conceito da seguinte forma:

Todo nome comum que seja familiar e tão bem conhecido em si mesmo, que pode ser empregado para julgar outras coisas, exprime um conceito. Mesa, pedra, pôr-do-sol, relva, animal, lua e outros, da lista de nomes comuns que possuam solidez e segurança, são conceitos, em sua significação. (Dewey, 1979a. p. 151/2) 
Mas como um nome comum chega a se tornar familiar? Ou como se originam os conceitos?

Já observamos que Dewey descarta a concepção que considera que o conceito deriva do processo mental de comparar uma multidão de objetos previamente entendidos e definidos. Neste processo as qualidades diferentes são excluídas de forma a restar as características comuns que compõem o conceito. O conceito seria resultado de uma "impossível espécie de análise", na qual os traços do objeto seriam clarificados e separados dos outros. Se ela fosse possível, "seria apenas uma coleção, um inventário ou agregado, não uma idéia geral." (Dewey, 1979a, p. 159)

A tese deweyana concebe a origem do conceito a partir do contexto de uso ou atividade prática. $\mathrm{O}$ significado das coisas se torna delimitado, definido ou distinto à medida que as coisas - objetos, sons, palavras, cores - fazem parte de um contexto de uso, de uma atividade prática, em que elas proporcionam auxílio ou prazer, prejuízo ou sofrimento. $\mathrm{Na}$ seguinte passagem, Dewey confirma esta tese: "o significado foi adquirido por participar de um contexto de uso, por trazer-nos auxílio e prazer - alimentos, móveis, roupas - ou prejuízo e sofrimento - como o fogo de que nos aproximamos demais, os alfinetes que nos arranham" (Dewey, 1979b, p. 148)

Na situação que antecede ao uso, as coisas não passam de uma "mancha difusa", "vaga", "amorfa”, "flutuante”, com variações não diferenciadas. Este princípio vale tanto para uma criança que inicia a aquisição de significados, quanto para o adulto, quando diante de uma coisa nova e estranha. A situação de não entendimento é a mesma para ambos. Diz Dewey: "O que não entendemos assume o caráter de mancha difusa, em que as variações não se discriminam" (Dewey, 1979a, p. 144) O significado vai se tornando definido e constante na medida em que agimos diante desta situação: "A aquisição de um significado definido e constante tem como fonte primeira a atividade prática." (Dewey, 1979a, p. 144) O contexto de uso ou a prática são formas de reação, de ajustamento da resposta de maneira que uma significação vai se destacando. Assim, o homem adquire inteligência no curso da luta pela sobrevivência. A explicação de Dewey é a seguinte:

Uso e gozo são os modos pelos quais os seres humanos estão diretamente conectados com o mundo que os rodeia. Questões de alimentação, abrigo, proteção, defesa, etc. são questões de uso que se pode fazer dos materiais do ambiente e das atitudes a serem tomadas praticamente em relação aos membros do próprio grupo e outros grupos tomados em seu conjunto. O uso, por sua vez, é por causa de alguma consumação ou gozo. Algumas coisas que estão fora do alcance do uso direto, tais como estrelas e antepassados 
falecidos, são objeto de uso mágico e gozo em ritos e lendas. (Dewey, 1960, p. 63)

O significado surge da relação meio-consequiência no uso ou atividade prática com as coisas. Assim o sentido nasce quando as coisas são "usadas como meio para obter conseqüências (ou meios para preveni-las quando indesejadas); ou como suporte de conseqüências para as quais temos de descobrir meios. A relação meio-conseqüência é o centro e núcleo de toda compreensão.” (Dewey, 1979a, p. 148, itálicos do autor)

A experiência da criança na formação de um conceito mostra que ela começa com uma significação específica do objeto, obtida num contexto de uso. A criança faz uma seleção de um traço, a partir das evidências que passa a ser distinto no conjunto da situação e lhe serve de guia. Esta significação é transportada como expectativa para as experiências subsequientes em que os objetos lhe servem de pretexto. Ela antecipa certos modos característicos de comportamento. Quando percebe que os traços do objeto ou seus modos de comportamento não se confirmam conforme esperado, a criança se vê obrigada a eliminar esta significação e escolher e focar outros. O processo conceitual é sempre orientado pela aplicação do resultado de uma experiência anterior como forma de compreender e tratar novos casos que entram na experiência. Assim, na medida em que uma significação se transforma em ferramenta de trabalho a ser usada e aplicada para a compreensão de novos casos, o conceito adquire generalidade.

O exemplo que Dewey cita é experiência da criança na elaboração do conceito cachorro. Inicialmente, como em qualquer processo de formação do conceito, a idéia que a criança tem de cachorro é "vaga, amorfa, flutuante". À medida que a criança observa outros animais - um gato, cavalo, porco, etc. - a criança é induzida a discriminar as qualidades de cada um dos animais. Demarca certa característica que pertence exclusivamente a seu cachorro. Este ponto de referência vai se padronizando e lhe serve para assimilar e selecionar os outros animais com os quais mantém contato. Acerca deste processo conclui Dewey:

Durante todo o processo, a criança foi experimentando adaptar a sua idéia, vaga ou indefinida, conforme seu estágio de experiência, a todos os animais que possuíssem alguma semelhança com cães, aplicando-a quando possível, e, quando não, tornando-se ciente das diferenças. Por esses processos, sua idéia adquire corpo, firmeza, distinção: torna-se um conceito. Pelos mesmos processos, uma idéia vaga, mais ou menos sem forma, adquire generalidade. O que equivale a dizer que os conceitos são gerais por causa do uso, da aplicação, não por causa de seus ingredientes. (Dewey, 1979a, p.158)

O conceito é um instrumento de trabalho que permite a generalidade de uma idéia.

Ele é geral exatamente por causa do uso e aplicação. Ele é um instrumento para apreender, 
compreender e explicar novos casos ou coisas ainda incertas e confusas que sem ele ficariam desconexas. Habilitam a generalizar, isto é, nossa compreensão pode ser estendida de uma coisa a outra, por representar uma classe ou grupo inteiro de coisas. Assim, para Dewey, as concepções são instrumentos que permitem a identificação de um novo objeto e lhe dá estabilidade. $\mathrm{O}$ conceito oferece um conjunto de significação que servem para interpretar e completar o novo objeto descoberto. Em terceiro lugar, o objeto descoberto deixa o estado de isolamento para fazer parte sistema de conhecimentos. Desta forma, os conceitos têm vantagem econômica: "economizam tremendamente nossos esforços intelectuais." (Dewey, 1979a, p. 152) Possibilitam também a padronização dos nossos conhecimentos: "Imprimem solidez ao que não tenha forma, permanência ao que seja mutável. [...] significa que determinado sentido ficou estabilizado e permanece o mesmo em diferentes contextos." (Dewey, 1979a, p. 152).

O processo da concepção envolve duas operações complementares que constituem a função do juízo: análise e síntese. A análise possibilita discernir e discriminar os fatos; a síntese, liga os fatos em função de uma conclusão. A definição de Dewey para estas operações: "Síntese é a operação que fornece extensão e generalidade a uma idéia; e a análise distingue o significado. Síntese e análise são correlativas." (Dewey, 1979a, p.159-160) Ambas se completam, dando consistência ao juízo. O juízo completa o processo do pensamento reflexivo sobre a situação problemática.

Retomando o exemplo do conceito "cachorro", a criança procedeu operando análises e sínteses. A análise ocorre quando uma qualidade é claramente discriminada, distinguida, tornando-se uma significação que serve de indício ou de guia para elucidar uma incerteza. Um sinal, ou um traço particular do cão é notado conscientemente, como por exemplo, quadrúpede, peludo, rabo, etc. Estas qualidades permitem, num processo de análise, traçar uma distinção que o cão não possuía antes, isto é, era um todo vago. Temos a síntese quando a criança aplica as significações a outros casos esses significados apreendidos num caso específico, de tal maneira que esses casos que eram antes separados são, agora, integrados num sistema consistente. Afirma Dewey: "Sempre que alguém transporta uma significação de um objeto para outro, que antes parecem de espécies diferentes, ocorre uma síntese.” (p. 160) Tanto a criança quanto o cientista procedem da mesma maneira, apenas este último trabalha com maior rigor. Eis a afirmação de Dewey:

A única diferença entre um tal caso e a análise efetuada por um químico ou botânico é que este se conserva de atalaia em relação aos indícios que lhe servirão para uma identificação segura, na área mais ampla possível de 
casos; é-lhe necessário achar sinais pelos quais identifique um objeto como pertencente a uma espécie ou classe definida, mesmo que se apresente em circunstâncias inusitadas e de forma obscura e disfarçada. (Dewey, 1979a, p.158, itálicos do autor)

Dewey desenvolve um estudo que busca a definição e organização dos significados. Neste estudo, ele alerta para as más conseqüências ou defeitos intelectuais que o indefinido poderá trazer. "O indefinido dissimula a mescla inconsciente de significação heterogêneas, facilita a substituição de uma significação por outra, mascara a ausência de qualquer definição precisa.” (Dewey, 1979a, p.161)

A definição e a organização dos significados desenvolvida por Dewey assenta-se sobre quatro termos: intensão e extensão, definição e divisão. A significação clara e individualizada, exclusiva e característica, homogênea, completa em si mesma - essa qualidade de princípio para indicar os particulares recebe o nome de nome técnico de intensão (intension); a definição retrata esse processo de chegar a essas unidades de sentido e de exprimi-las. Vejamos como ele amarra essas idéias: "A intensão (Intension) dos termos 'homem', 'rio', 'honestidade', 'supremo tribunal' é a significação que se lhes associa, exclusiva e caracteristicamente, e que aparece na definição dessas unidades de sentido. (Dewey, 1979a, p.162/3, itálicos do autor) A intensão designa o sentido sob três possíveis formas, diz Dewey:

(1) como significação das palavras, quaisquer sejam suas formas lógicas; (2) como um sinônimo de um conjunto de características que constitui a força descritiva de um termo denotativo; (3) como sinônimo da significação lógica de um termo abstrato conotativo ou atributivo.(Dewey, 1960, p. 362)

Uma significação empregada com clareza para extremar e enfeixar um grupo de coisas, principalmente quando os objetos têm sentido muito aproximado, constitui sua extensão. Indica um grupo ou classe de particulares identificados e distintos segundo as significações características. Assim, a significação 'rio' somente poderá designar o Tietê, Paraná, São Francisco, Amazonas, mesmo havendo diferenças entre eles, mas não poderá dar a entender coisas como lago, correntes oceânicas, etc. A extensão do termo poderá criar confusão lógica se não se referir estritamente a gênero: “a extensão é uma propriedade de termos denotativos (a saber, aqueles que se referem a gêneros e não a singulares) (Dewey, 1960, p. 361) Resumindo a questão: “Assim como a definição estabelece a intensão, (intension), a divisão (ou seu reverso, a classificação) designa a extensão (extension). Intensão e extensão, definição e divisão, são claramente correlativas." (Dewey, 1979a, p.162/3, itálicos do autor) 
A definição e a divisão quando operam conjuntamente fixam e organizam os significados. Elas fornecem significações precisa e indicam o grupo de objetos que se referem, a espécie de coisas significadas e as suas subclasses. A definição e classificação dos significados de uma série de experiência poderão dar origem a uma ciência, na medida em que servem de princípio para a organização e agrupamento das experiências.

Dewey classifica as definições em três tipos: denotativas, conotativas ou expositivas e científicas.

As definições denotativas indicam o método pelo qual delimitamos uma significação, provocando uma atitude a respeito dos objetos; elas se aplicam às qualidades sensíveis, tais como sabores, cores, etc. como também às emotivas e morais - honestidade, ódio, simpatia, etc.

O termo é denotativo, diz Dewey quando ele se refere à existência. "nomes comuns, demonstrativos, e verbos que denotam mudança ou ação são denotativos." (Dewey, 1960, p. 355)

As definições conotativas ou expositivas resultam das combinações, variações ou associações que podemos fazer na imaginação e por meio da linguagem a partir de um acervo de significações delimitadas direta ou denotativamente. Elas se restringem ao significado de um termo denotativo e não possuem nem denotação nem extensão. Diz Dewey: "recorrendo a significações mais familiares e associando-as, conseguimos que fiquem ao nosso dispor, as reservas de significados acumulados pela comunidade." (Dewey, 1979a, p.164). O perigo destas definições está no seu caráter de serem convencionais e de segunda mão, sujeitas à influência da autoridade e não da observação e experimentação diretas. Como exemplo, podemos recorrer às definições do dicionário.

As duas definições se completam: "Termos existenciais são denotativos; termos abstratos são conotativos. Todo termo denotativo está relacionado a um termo conotativo correspondente ou conjugado na medida em que sua capacidade denotativa está garantida. (Dewey, 1960, p. 356)

As definições científicas são caracterizadas por adotar as condições de causalidade, produção e gênese, para exprimir uma relação. Elas não se baseiam nas qualidades ou propriedades imediatamente perceptíveis ou úteis, que são as características de uma definição popular. A base destas definições é a relação causal e genética de uma coisa com outra no processo de construção do objeto científico. Este modo de definir se torna a chave que 
incorpora os objetos a certa categoria. Assim, as definições causais e genéticas, diz Dewey, “explicam a razão de pertencerem a uma classe ou possuírem determinados caracteres comuns, na base de sua maneira de produção.” (Dewey, 1979a, p.164)

Para encerrar este capítulo em que analisamos o papel do conceito na investigação lógica, queremos introduzir ainda três conceitos que Dewey desenvolve na obra Knowuing and the known. Referimo-nos aos três níveis de investigação organizados por Dewey, conforme o aparecimento histórico de acordo com evolução e através dos quais o "velho" sobrevive através do "novo". Dewey refere-se da seguinte forma estes níveis: "Estes níveis são todos comportamentos humanos dentro de e com respeito ao mundo, e são todos apresentações do próprio mundo, tal como é descrito pelos homens." (Dewey, 1991b, p. 100101) Vejamos os três modos científicos sucessivos e progressivos de ver o mundo:

Ação-própria (self-action): onde as coisas são revistas como agindo sob seus próprios poderes.

Interação (inter-action): onde a coisa é comparada a coisa dentro de uma interconexão casual.

Transação (Trasn-action): onde sistemas de descrição e denominação são empregados para lidar com aspectos e fases da ação, sem atribuição a "elementos" ou outras "entidades", "essências", ou "realidades" presuntivamente destacáveis ou independentes e sem isolação de "relações" presuntivamente destacáveis de tais "elementos" destacáveis. (Dewey, 1991b, p. 101-102)

\subsection{Conceito: cultura e comunicação}

$\mathrm{O}$ meio em que os seres humanos vivem e atuam não é meramente físico, mas também cultural. O comportamento vivo e as atividades distintamente humanas como respostas ao meio físico são influenciadas pelo ambiente cultural. Pode-se até dizer que o ambiente físico está incorporado no ambiente cultural. O efeito das condições culturais transforma a relação do organismo com o meio fazendo não apenas que os problemas tenham conteúdos diferentes, mas que sejam tratados como problemas, gerando processos de investigação em busca da solução. Na seguinte passagem, podemos perceber como Dewey entende esta questão:

Por um meio cultural, as condições físicas são modificadas por um complexo de costumes, tradições, ocupações, interesses e propósitos que os envolvem. De maneira correspondente, transformam os modos de resposta. Manifestam em si mesmos o significado que as coisas adquirem e os sentidos providos pela linguagem. (Dewey, 1960, p.60) 
Neste ponto Dewey concorda com a afirmação de Aristóteles que concebe o homem como um "animal social". A situação em que o homem se encontra, e os problemas e formas de solucioná-los, não tem precedentes no nível biológico. A condição social do ser humano difere muito das condições de certas espécies que sobrevivem socialmente, como abelhas e formigas. O ambiente que o ser humano atua é culturalmente transmitido. Portanto, sua atividade é determinada, não apenas pelas estruturas orgânicas e herança física, mas, sobretudo, pela herança cultural incorporada em tradições, instituições, costumes. Esta herança é de fundamental importância para o ser humano, pois introduz novas atitudes e modos de responder e modifica, inclusive, as estruturas neuro-musculares dos indivíduos. Diz Dewey: "Falar, ler, exercitar qualquer arte, industrial, bela ou política, são exemplos de modificações produzidas dentro do organismo biológico pelo ambiente cultural." (Dewey, 1960, p. 43) O ambiente cultural, condição e produto da linguagem, modifica a conduta orgânica e acrescenta a propriedade intelectual conceitual ou significativa. As significações são caracteres que incorporados à sensibilidade transformam a ação orgânica em ação compartilhada e inteligente.

A importância da linguagem como condição necessária e, em ultimo caso, como condição suficiente para a existência e transmissão de atividades não puramente orgânicas, e suas conseqüências, reside no fato que, por um lado, um modo de comportamento estritamente biológico surge em natural continuidade de atividades orgânicas prévias, enquanto que, por outro lado, força o indivíduo a adotar o ponto de vista dos outros e a olhar e investigar sob o ponto de vista que não é estritamente pessoal, mas em comum com os outros indivíduos como participantes ou 'partes' de uma atividade conjunta. (Dewey, 1960, p. 46)

O ambiente cultural ao atuar modificando a conduta orgânica dota esta de propriedades intelectuais. O desenvolvimento da linguagem neste ambiente cultural é a chave para compreender esta transformação da conduta humana. Dewey coloca da seguinte forma esta questão:

A transformação do comportamento orgânico em comportamento intelectual, caracterizado por propriedades lógicas, é produto do fato de que os indivíduos vivem em um ambiente cultural. Este viver os força a assumir, em seu comportamento, o ponto de vista dos costumes, crenças, instituições, significados e projetos que são pelo menos relativamente gerais e objetivos. [...] A linguagem ocupa um lugar destacado e exerce uma função peculiarmente significativa no complexo que forma o ambiente cultural. Ela é em si mesma uma instituição cultural. [...] Ela é (1) a agência através da qual outras instituições e hábitos são transmitidos, e (2) ela permeia tanto as formas como os conteúdos de todas as demais atividades culturais. Além disso, ela tem a sua própria e distintiva estrutura que pode ser abstraída como uma forma. (Dewey, 1960, p. 45) 
Dewey toma a linguagem num sentido amplo, não se restringindo à linguagem oral ou escrita. Inclui também os gestos, ritos, cerimônias, monumentos, produtos de belas artes e da indústria. Os instrumentos, ferramentas, utensílios, máquinas, são, para Dewey, mais do que objetos físicos, simples ou complexo, com suas próprias qualidades e efeitos físicos, são também um modo de linguagem.

As significações incorporadas na linguagem, e desta forma na sensibilidade, transformam a ação orgânica, fornecendo-lhe novas propriedades. Afirma Dewey: "Todo pensamento e significação têm seu substrato em algum ato orgânico de absorção ou eliminação, de busca ou rejeição, de destruição ou cuidado, de sinal ou de resposta." (Dewey, 1958, p. 290) Os atos biológicos persistem, mas ampliam infinitamente a significação, a partir das recombinações possíveis com o uso da linguagem, que torna acessível o contato com as aquisições dos outros, acumuladas historicamente. A comunicação modifica as formas orgânicas de agir, transforma acontecimentos em objetos ou coisas com uma significação, acrescentando-lhes novas qualidades transformando-os, assim, também em instrumentos.

Para Dewey há continuidade entre a dimensão orgânica da significação e a dimensão social. A linguagem, os símbolos, a significação e o uso de instrumentos constituem o elo de ligação. Dewey compreende que a origem e o desenvolvimento dos instrumentos ocorrem dentro de grupos sociais através do recurso da linguagem "As coisas tornam-se instrumentos por meio de cerimônias e instituições.” (Dewey, 1958, p. 187) Os utensílios primitivos e os correspondentes simbolismos indicam este caráter convencional e tradicional do uso por uma coletividade humana. Além disso, instrumentos e utensílios estão sempre ligados a alguma forma de divisão do trabalho e formas de comunicação. A experiência imediata é transitória e pode se dissipar, se não for fixado em algum ato de fácil recordação e repetição, e uso sob domínio do organismo como gestos e sons. Por exemplo, o uso do fogo para se aquecer, o uso de pau para remexer a terra favorecendo o desenvolvimento de certas plantas são relações de causa-conseqüência sujeitas à extinção, se não forem distinguidas e retidas de alguma forma. O excerto citado a seguir mostra como Dewey relaciona o papel da linguagem na retenção das relações e a comunicação como condições de existência à consciência:

Unicamente a linguagem ou alguma forma de sinais artificiais serve para registrar a relação e torná-la frutífera em outras condições de existência particular. Lanças, urnas, cestos, laços podem ter se originado acidentalmente em certa conseqüência final de eventos naturais. Porém, unicamente a repetição, através de uma ação em concordância, explica o fato de terem se institucionalizado como instrumentos, e este acordo da ação depende do uso de memorando e comunicação. Fazer o outro consciente da possibilidade de usar relação objetiva é perpetuar o que de outro modo se 
reduz a um acidente ocasionalmente eficaz; a comunicação é condição da consciência. (Dewey, 1958, p. 187)

A institucionalização de um instrumento o torna tão ligado às ocupações, interesses e propósitos que ele se torna linguagem capaz de evocar significações. Operando desta forma, a significação torna-se algo comum entre duas ou mais pessoas e a coisa a que se referem. $\mathrm{O}$ resultado natural é que a significação se torna objetiva, um meio de generalizar. Neste sentido, a significação se transforma em método de agir compartilhado: "Uma significação é um método de ação, uma forma de usar coisas como meio para consumar algo em companhia, e o método é geral, ainda que sejam particulares as coisas a que se aplica." (Dewey, 1958, p. 187)

Significação, linguagem, comunicação criam a base que serve de sede à própria mente e dá condições de existência à consciência ${ }^{28}$. Dewey entende que quando o significado opera como objetivo ou intenção de certa ação conjunta constitui a própria consciência: "Consciência não é uma coisa que possuímos para olhar ociosamente o cenário que nos cerca ou para que seja impressionada pelas coisas do mundo exterior; consciência é a denominação da qualidade intencional de uma linha de ação, da qualidade da atividade que é orientada por um objetivo." (Dewey, 1979b, p. 112)

A linguagem é pensada por Dewey como o instrumento da cooperação social e estabelece a continuidade entre a origem e desenvolvimento das significações ${ }^{29}$. Dewey coloca a linguagem como o "instrumento dos instrumentos" (cf. Dewey, 1958, p. 186), uma vez que o próprio uso dos instrumentos está sujeito às condições aportadas na linguagem. A aptidão para responder às significações e empregá-las, não se limitando às reações dos contatos físicos constitui a experiência inteligentemente dirigida que diferencia o homem dos demais animais e o emancipa.

A análise deweyana da linguagem como instrumento comporta dois aspectos, o lógico e o social. Dewey destaca a primazia do social: "É certo que a linguagem é um instrumento lógico, porém é fundamental e primariamente um instrumento social. A linguagem é um meio de comunicação; é o instrumento por meio do qual o indivíduo chega a participar nas idéias e sentimentos dos outros." (Dewey, 1940, p. 61) A linguagem como

\footnotetext{
${ }^{28}$ Consciência, idéia, é aquela fase de um sistema de significação que em um dado momento, está passando por uma redireção, por uma transformação transitiva. (Dewey, 1958, P. 308)

29 A linguagem é uma função natural da associação humana; e suas conseqüências reagem sobre outros acontecimentos, físicos e humanos, dando-lhes significação ou sentido" (Dewey, 1958, p. 173)
} 
instrumento da continuidade social e sob o ponto de vista lógico, requer a padronização dos conceitos. Somente desta forma, a necessidade social da comunicação eficiente e a internalização de significados podem ser eficazes:

[...] a necessidade social de sentidos que sejam os mesmos para duas pessoas, a despeito das diferenças de suas experiências de vida, é uma das principais forças que determinam a padronização dos significados. Depois de socialmente estabilizados, pode o indivíduo regularizar a marcha de seu pensamento, porque alguns dos pensamentos se mantêm constantes em sua referência: "cadeira" significa sempre o mesmo; assim, "sol", "água", "terra", etc. Cada nome de nosso repertório inteiro de nomes comuns referese sempre ao mesmo objeto, apesar das diferenças de lugar, tempo e outras condições da experiência. (Dewey, 1979a, p. 153)

Esses significados necessários ao pensamento se "fixam" ou "prendem" em sinais ou símbolos que compõem a linguagem. Os sinais ou símbolos são instrumentos, utensílios artificiais projetados ou inventados para este fim, ou seja, são sinais intencionais que compõem a linguagem e que lhes dá existência física. Entretanto, eles operam em função de sua capacidade representativa de significação, que é resultado da convenção. Diz Dewey: "A existência física particular dotada de sentido é, no caso do discurso, algo convencional." (Dewey, 1960 p. 46) Eles têm uma existência física, mas não operam como coisas puramente físicas, quando são meios de comunicação. Eles operam em função de sua significação. Diz Dewey: "Operam em virtude de sua capacidade representativa ou de sentido. A existência física particular dotada de sentido é, no caso da linguagem, algo convencional.” (Dewey, 1960 p. 46) A convenção ou consentimento resultam de um acordo na ação compartilhada em e por uma comunidade de uso funcional. É necessário deixar claro o sentido que possui um símbolo convencional. A convenção não se refere à existência física de uma mera palavra ou símbolo, mas à coincidência de conseqüências, do sentido mutuamente participadas em uma comunidade de ação.

A convenção não se refere à existência física como se falássemos de uma mera palavra ou símbolo como algo isolado ou parte da linguagem. Diz Dewey: "Cada palavra ou frase possui o sentido unicamente como membro de uma constelação de sentidos relacionados. As palavras, em sua função representativa, são partes de um código amplo." (Dewey, 1960 p. 49) O seu sentido é determinado em função da sua relação com um código do qual faz parte em conexão direta com as conseqüências mutuamente participadas em uma comunidade de ação. Entretanto, existe uma multiplicidade de constelações de linguagemsignificado em nossa cultura. Intelectualmente temos várias linguagens; socialmente apenas uma, conforme cada grupo social. O significado das palavras varia conforme elas são usadas 
na religião, no comércio, no campo jurídico, etc. Para sair desta "Babel da comunicação", Dewey aponta para o ideal de uma linguagem científica:

Uma comunidade genuína de linguagem ou símbolos pode-se conseguir somente através de esforços que produzam uma comunidade de atividades sob as condições existentes. O ideal de uma linguagem científica é a construção de um sistema em que os diversos 'sentidos' são relacionados entre si na inferência e discurso e onde os símbolos sejam tais que denotem esta relação. (Dewey, 1960 p. 50/51)

Considerando, especificamente a linguagem da ciência, Dewey alerta que ela apresenta severas dificuldades para ser aprendida:

A ciência, em outras palavras, é uma linguagem altamente especializada, mais difícil de ser aprendida que qualquer linguagem natural. Ela é uma linguagem artificial, Não no sentido de ser artificial, mas no sentido de ser um trabalho de arte complexo, devotado a um propósito particular e incapaz de ser adquirida e entendida na forma, como a linguagem materna é aprendida." (Dewey, 1991a, p. 168)

Em termos gerais, a linguagem é o instrumento social da significação. Como veículo, a significação, isolada e fixada num símbolo, subsiste quando a coisa desaparece. Poderá ser usada em novo contexto ou situação, isto é, pode ser transferida, reaplicada, utilizando-se do passado para julgar e inferir o novo, constituindo assim, a chave de todos os juízos e inferências. Dessa forma, é possível um crescimento cumulativo da inteligência, na qual a experiência passada é um lastro para antecipar e regular uma nova experiência. Assim, o pensamento se habitua, ao empregar a linguagem, a utilizar, sem consciência explícita, as "sistematizações intelectuais da raça" (Dewey, 1979a, p. 232), isto é, as classificações, as distinções, os agrupamentos lógicos.

Pela comunicação os acontecimentos são reconsiderados, revisados, readaptados, transformados em objetos ou coisas com significados atendendo às exigências da conversação, tanto em nível de discurso do pensamento internalizado quanto público. Os acontecimentos nomeados adquirem vida dupla e independente de espaço, tempo e contexto. As significações podem ser levadas ao plano ideal da experimentação interna, onde pensamento e imaginação fazem infinitas combinações e elaborações lógicas. "Onde existe a comunicação, as coisas ao adquirirem significado, adquirem da mesma forma representantes, substitutivos, ou seja, sinais, e implicam outras que são infinitamente mais susceptíveis de manejo, mais estáveis e mais adaptáveis, que os acontecimentos em seu primeiro estado. (Dewey, 1958, p. 167) As coisas ganham um incremento novo e adquirem importância ao se tornarem representativas, e se transformam adquirindo a "dignidade de uma função" 
Dewey coloca a questão da transformação das ações orgânicas psicofísicas em atos psíquicos, condição que é dada pela linguagem, ou seja, através do discurso. "Pensa-se que a introspecção é um retirar-se para um mundo particular de acontecimentos, um mundo de materiais espirituais, entretanto, nada mais é do que concentrar a atenção sobre o próprio solilóquio: E o solilóquio é o produto e o reflexo da conversação com os demais, e não a comunicação social um efeito do solilóquio." (Dewey, 1958, p. 170) É em virtude da comunicação, que se torna possível a conversação consigo mesmo e o nascimento do espírito:

Em virtude da comunicação, do dar e receber social, várias atitudes orgânicas tornam-se um conjunto articulado de pessoas envolvidas na conversação, aconselhando um ao outro, trocando experiências distintas, ouvindo um ao outro, não ouvindo o que não querem ouvir, acusando e desculpando. Através do discurso, uma pessoa identifica dramaticamente a si mesma com atos potenciais e feitos; ele desempenha muitos papeis não em estágios sucessivos da vida, mas num drama representado contemporaneamente. Assim nasce a mente. (Dewey, 1958, p. 170)

Dewey analisa o desdobramento que teve a descoberta do discurso na experiência grega e moderna. Os gregos descobriram a estrutura do discurso racional e lógico e tomaram esta estrutura pela estrutura das coisas, como espelho da natureza. Os modernos fizeram do discurso um mundo de existências espaciais e temporais, separado e privado composto de sensações, imagens e sentimentos. Desta forma descobriram a experiência interna. Entretanto, não perceberam a linguagem como um acontecimento da experiência: “A linguagem é uma função natural da associação humana, e suas conseqüências reagem sobre os outros acontecimentos, físicos e humanos, dando-lhes sentido ou significação. (Dewey, 1958, p. 173) E como acontecimento da experiência socializada, amplia as energias que entram nela, dandolhes qualidades adicionais ou significados que são estendidos e transferidos, real e potencialmente a toda as coisas da natureza. Os acontecimentos adquirem caráter geral e distinto, uma significação comunicável, sendo suscetível de conotação e denotação. Desta forma tornam possível a inferência e o raciocínio.

O enfoque social da linguagem traz à tona a questão da interação dos seres humanos. Dewey considera, de acordo com o que estivemos analisando, absurda a idéia que os indivíduos se tornam sociais. Os seres humanos mantêm as mesmas características de interação que as demais coisas, ou seja, a singularidade e a associação. A inclusão dos indivíduos não é um fato novo e sem precedentes, mas a manifestação do seu lugar comum de existência. O importante no processo de interação são as conseqüências que brotam dos distintos tipos de sociedade. A consideração que se faz importante reside no fato de que a associação humana transforma a seqüência e coexistência natural em participação. 
A origem da linguagem não ocorreu pela simples existência de sons e gestos. A sua origem se deve ao uso destes produtos espontâneos - gritos e gestos - num contexto de ajuda mútua e direção das ações. Eles são transformados em nomes, coisas com significação. Assim, a história da linguagem é a história do uso das ocorrências de gestos e sons, um subproduto destes usos e não algo intencional ou mental primariamente. A observação da experiência animal ilustra este fato. O comportamento animal como resposta a certos estímulos não tem conseqüências diretas e úteis para seu próprio comportamento, mas serve de estímulo para outros animais. Este sinal emitido por um animal pode despertar respostas características (reflexo), como proteção, alimento, atividade sexual. Em alguns casos pode ter conseqüências importantes para o primeiro agente ou para todo o grupo como nos casos de proteção e reprodução. O mesmo pode ocorrer com o ser humano: o choro de um bebê, as expressões faciais, os gestos, as posições do corpo, etc. podem servir de sinal para o observador reagir sem que o outro tenha tal intenção. Os atos de sinal atuam como condição material para a linguagem, mas não são linguagem nem condição suficiente para ela. Um bebê aprende a tratar os movimentos dos pais como sinal de acontecimentos ulteriores, caracterizando uma resposta à significação e não meramente a um sinal. Nesta linha de raciocínio, as respostas de um animal se dão em relação aos sinais, enquanto a resposta do homem é dada em função de símbolos. Diz Dewey: "A atividade de uma galinha é egocêntrica; a do ser humano é participativa. Este se coloca o ponto de vista de uma situação em que tem parte dois seres. Esta é a peculiaridade da linguagem ou dos sinais." (Dewey, 1958, p. 178) A essência da linguagem ou significado é a experiência compartilhada, ou seja, há compreensão de um processo de antecipação conjunta e com referência recíproca: "É uma comunicação; o estabelecimento de cooperação numa atividade na qual há partícipes e na qual a atividade de cada um está modificada e regulada pela participação.” (Dewey, 1958, p. 179) E inteligência consiste na capacidade de se engajar e levar adiante tal atividade: "Inteligência e significado são conseqüências naturais da singular forma que às vezes a interação assume no caso dos seres humanos. (Dewey, 1958, p. 180)

A forma da situação que ocorre à significação e à compreensão a que Dewey se refere inclui a presença simultânea e uma relação mútua do imediato e eficiente, o real e o potencial, o consumador e o instrumental. A significação não pode ser compreendida apenas como algo físico ou psiquicamente existente, mas é dado primariamente na conduta, cooperativa e secundariamente nos objetos. Por isso, a significação é intenção, e neste caso não pode ser algo exclusivamente íntimo ou pessoal. A significação de um sinal acontece 
numa "comunidade de participação", ou seja, na interação entre pelo menos duas pessoas que têm algo em comum entre si e um objeto e a existência de um grupo organizado, que adquiriu hábitos verbais comuns, aos quais as pessoas pertencem. Os sentidos não podem ser entendidos, diz Dewey, “com independência de sua força operativa comunal.” (Dewey, 1960, p. 48)

Da mesma forma, a finalidade e a instrumentalidade não se encontram nas coisas puramente físicas, abstraindo de uma situação de comunicação. Embora todas as coisas e acontecimentos possam ser concebíveis e entrar num discurso que atribui significações e relações lógicas estas são retrospectivas. Causam prejuízo quando se tornam dogmáticas ou literais. Sobre o acontecimento e a significação, Dewey considera que "o que é diretamente um acontecimento e o que ele pode fazer, ou as relações em que pode entrar, são duas coisas distintas e incomensuráveis. Porém, quando um acontecimento tem significação, suas consequiências potenciais se tornam aspectos sólidos e integrais.” (Dewey, 1958, p. 182) A recorrência ou repetição das conseqüências possibilita a definição: "Quando as consequiências potenciais são importantes e repetidas formam a natureza e essência ${ }^{30}$ mesma da coisa, sua forma que a define, identifica e distingue. Reconhecer a coisa é formular sua definição." (Dewey, 1958, p. 182) A definição torna possível a percepção das coisas, diz Dewey: "Perceber é reconhecer possibilidades não alcançadas; é referir o presente às conseqüências, manifestação do desfecho, e, portanto conduzir-se obedecendo as conexões dos acontecimentos. Enquanto atitude, a percepção ou a impressão de algo é expectativa previsora, prudência. (Dewey, 1958, p. 182).

Estudando o discurso, Dewey acrescenta que pode ter duas características: a de ser consumador e instrumental. Assim, ora a comunicação é um intercâmbio que proporcionar algo desejado: pedidos, chamadas, ordens, etc.; ora ela é imediata realização em si mesma pela qual se goza a vida: na música, na apreciação das cenas de perigo e vitória, saudações, inclusive o discurso científico é suscetível de tornar-se objeto de gozo para aqueles que se interessam. O discurso filosófico gera fascinação peculiar, que estimula o filosofar. Afirma

\footnotetext{
${ }^{30}$ Deve-se entender essência como um caso relevante de significação, mais difundida e reiterada, e nunca, a existência. Diz Dewey: “A essência não é nunca a existência e ainda assim é essência, o produto destilado da existência, a coisa importante acerca desta, sua justificativa intelectual, o meio de inferir e transferir extensivamente e objeto da intuição estética. Nela, o sentir e o entender são uma coisa só, o significado de uma coisa é o sentido que ela faz. (p. 183)
} 
Dewey: "Compartilhar a experiência é o maior dos bens humanos." (Dewey, 1958, p. 202) A linguagem tem sempre o caráter de ação compartilhada:

A linguagem é sempre uma forma de ação e em seu uso instrumental é sempre um meio de ação concentrada em vista de um fim, ao mesmo tempo em que encontra em si mesma todos os bens de suas possíveis conseqüências. Pois, não existe forma de ação tão realizadora e tão recompensadora como a ação coletiva e coordenada. Ela traz consigo o sentimento de participar e fundir-se em um todo." (Dewey, 1958, p. 184)

Pelo seu lado instrumental a comunicação nos libera do caráter opressivo dos acontecimentos, oferecendo uma vida conduzida por significados e enriquecida por eles. Pelo seu lado consumador, a comunicação permite participar dos objetos e artes de valor para uma comunidade. Os significados partilhados são ampliados, aprofundados e solidificados no senso de comunhão, elevando o homem de seu isolamento. Conclui Dewey, afirmando a importância da interação destas duas dimensões: "quando na experiência vivem juntas as funções instrumentais e finais da comunicação existe uma inteligência que é o método e o prêmio da vida em comum e uma sociedade digna de atrair o amor, a admiração e a lealdade." (Dewey, 1958, p. 205)

Anteriormente falamos sobre a vida do ponto de vista físico, e como a contínua adaptação do ambiente proporcionou um ambiente amplamente modificado com e evento da linguagem e da comunicação. A vida humana se tornou um acontecimento social lastreado pelo conceito que subentende costumes, instituições, crenças, vitórias e derrotas, divertimentos e ocupações, lastreando de riqueza a experiência do indivíduo. (cf. Dewey, 1979b. p. 2) Assim como ocorre renovação da vida física, também ocorre renovação da vida social dando continuidade à experiência. A continuidade da vida social é obra da educação. Dewey manterá intactos, desde os seus primeiros escritos, os princípios da continuidade e interação entre o indivíduo, a sociedade e a educação:

Creio que o indivíduo que há de ser educado é um indivíduo social, que a sociedade é uma união orgânica de indivíduos. Se eliminamos da criança o fator social, ficamos somente com uma abstração. Se eliminarmos da sociedade o fator individual ficamos somente com uma massa inerte e amorfa. (Dewey, 1940, 54)

Confirmamos esta intuição deweyana com outra passagem em que ele aponta a complexidade da conversão da condição biológica à comunidade de linguagem. $\mathrm{O}$ excerto, apesar de longo, nos introduz nas duais questões que seguem: a democracia e a educação.

O trabalho de conversão da fase orgânica e física do comportamento associado numa comunidade de ação saturada e regulada pelos interesses 
mútuos nos significados partilhados, conseqüências que são traduzidas em idéias e objetos desejados por meio dos símbolos, não ocorre toda de uma vez nem completamente. A cada momento, ela apresenta problemas mais do que uma aquisição assentada. Nós nascemos seres orgânicos associados com os outros, mas nós não nascemos membros de uma comunidade. A criança tem que ser trazida através das tradições, perspectivas e interesses que caracterizam a comunidade por meio da educação: por uma ininterrupta instrução e por aprender em conexão com o fenômeno da associação aberta. Tudo o que é distintivamente humano é aprendido, não é inato (native), mesmo que não seja possível aprender sem estruturas inatas que diferenciam o homem de outros animais. Aprender na forma humana e no efeito humano não é somente adquirir habilidades acrescentadas por meio do refinamento de capacidades originais.

Aprender a ser humano é desenvolver através do dar-e-receber da comunicação um senso efetivo de ser um membro distintivamente individual de uma comunidade; alguém que entende e aprecia suas crenças, desejos e métodos, e que contribui para converter as forças orgânicas em recursos e valores humanos. Mas a tradução nunca termina. O Velho Adão, o elemento não regenerado na natureza humana persiste. (Dewey, 1991c, p. 153/154)

O nervo ciático da dimensão social é sem dúvida a dimensão pública. A dimensão pública se constitui pela publicidade: "Não existe o público sem a integral publicidade com respeito a todas as conseqüências que ela acarreta." (Dewey, 1991c, p. 167) Mas é ilusão achar que a ausência de restrições legais promove a liberdade de pensamento e comunicação. Se esta prática perpetua a infantilidade social, a sua remoção é apenas uma condição negativa. Por vezes a opressão externa atua como desafio que desperta as energias intelectuais exercita a coragem. A fé do iluminismo no avanço da ciência como forma de produzir instituições livres e promotoras da liberdade não se sustenta mais. $\mathrm{O}$ avanço da ciência e tecnologia provocou concentração do capital e gerou uma série de novos problemas. Neste sentido, Dewey tece duras críticas em vários escritos:

Pôs à disposição de ditadores meios de controlar a opinião e o sentimento de tal potência que se reduzem a meras sombras todas as agências anteriores sob o comando de governos despóticos. Substitui a censura negativa pelos meios de propaganda de idéias e de alegada informação, numa escala que atinge a cada indivíduo, reiterada dia sobre dia, por todos e cada um dos órgãos de publicidade e comunicação, velhos ou novos. (Dewey, 1970, p. 218)

Em sua análise da lógica Dewey reconhece a continuidade entre o senso comum e a ciência. A diferença é mais social do que lógica. É uma diferença de linguagem. E Dewey coloca que o problema no intercurso entre ambas: "O caminho da comunicação entre o senso comum e a ciência é, em grande parte, via de mão única. A ciência tem como ponto de partida o senso comum, mas o caminho de volta ao senso comum é tortuoso e bloqueado por condições sociais existentes. (Dewey, 1960. p.77) 


\subsection{A democracia e a reconstrução social dos conceitos e da inteligência}

Em nossa pesquisa sobre a concepção no pensamento deweyano, observamos seguidamente o cuidado do autor na análise dos termos. Ao tratar da questão social e da democracia, Dewey traz à tona o problema do uso dos termos sociedade e comunidade: eles são ambíguos. O pressuposto da unidade ideal que estes termos sugerem não se confirma nos fatos. Podemos observar a pluralidade de organizações, tanto boas como más, solidárias ou opostas. Exemplos a que se podem recorrer são os conluios criminosos, agremiações comerciais que exploram e saqueiam o público, grupos políticos que se mantêm unidos pelo interesse da pilhagem, até mesmo certas famílias ou grupos religiosos, que segregam pessoas ou grupos estranhos ou diferentes. Entretanto, todas estas organizações mantêm entre si as qualidades da sociedade, que, por sua vez, mantêm unidos seus membros, segundo o interesse comum, a fidelidade a regras e códigos, a afeição fraterna, o afeto e o auxílio mútuos.

Dewey coloca, então, a necessidade de investigar critérios ou medidas de valor que possam ser aplicados para qualquer modo de vida social e reconstruir os conceitos de sociedade e comunidade democráticas. Esta investigação deve evitar dois extremos: criar imaginativamente uma sociedade ideal, pois o critério seria inexeqüível. Por isso, o critério tem que ser buscado em sociedades existentes, de forma a garantir sua exeqüibilidade. Por outro lado, o critério ideal não pode se restringir à reprodução dos traços que já existem.

Os dois critérios que Dewey julga preencher estes requisitos são: o interesse comum e certa porção de interação e reciprocidade cooperativa com outros grupos. A maior ou menor graduação de presença destes critérios torna a vida mais ou menos social ou anti-social, amplia ou impede a endosmose social. Conforme expõe Dewey: "Os dois critérios para aferirse o valor de alguma espécie de vida social são a extensão em que os interesses de um grupo são compartidos por todos os seus componentes e a plenitude e liberdade com que esse grupo colabora com outros grupos." (ibidem, p. 106) A partir destes critérios que Dewey adota como padrão de julgamento, ele desenvolve uma análise detalhada, de como tal padrão se aplica em diversos grupos, desde uma quadrilha de malfeitores, a vida familiar, a um governo despótico, a divisão de classes, o mundo do trabalho.

Interessa-nos resgatar desta análise de Dewey, a relação que ele estabelece entre estes critérios e o desenvolvimento intelectual, social-democrático e educacional. A expansão da vida mental é dependente do crescente contato e experiências com o meio físico e das relações 
sociais. Neste sentido, Dewey coloca que diante da inexistência dos critérios mencionados na vida social, a experiência perde em significação, pois fica restrita a poucos estímulos para o pensamento se sentir desafiado à pesquisa: A falta do livre e razoável intercâmbio, que nasce de vários interesses compartidos, desequilibra o livre jogo dos estímulos intelectuais. Variedade de estímulos significa novidade, e novidade significa desafio e provocação à pesquisa e pensamento. (ibidem, p. 84/85)

Um caso que é digno de estudo é a divisão do trabalho. No caso do escravo, diz Dewey, referindo-se à definição de Platão, os objetivos que orientam a conduta do homem são recebidos de outro com supressão do interesse pessoal e a não compreensão da utilidade social de sua atividade. A organização social do trabalho, que o transforma em rotina maquinal, cega o trabalhador das relações técnicas, intelectuais e sociais de sua atividade com as demais partes do trabalho, e este não exerce a sua função a partir desta compreensão. Compromete assim o desenvolvimento e a vida intelectual e emocional e, consequentemente, a vida social.

A reflexão de Dewey sobre este problema merece ser citada:

A tendência a reduzir coisas como a eficácia da atividade e a organização científica do trabalho a técnicas puramente externas, é a prova do ponto de vista unilateral que possuem os que dirigem a indústria - aqueles que lhe determinam os fins. Alheados de largos e bem equilibrados interesses sociais não têm eles estímulo intelectual suficiente para se voltarem aos fatores e relações humanos envolvidos na atividade industrial. As idéias a esse respeito restringem-se aos elementos referentes à produção técnica e à comercialização dos produtos. Não há dúvida de que nestes estreitos limites pode haver grande desenvolvimento, mas nem por isso a circunstância de não se tomarem em conta importantes fatores sociais deixa de significar uma grande lacuna da colaboração espiritual, com um correspondente dano da vida emocional dos que trabalham. (ibidem, p. 91)

Assim, isolamento e rotina significam restrição para a vida social. "A verdade fundamental é que o isolamento tende a gerar, no interior do grupo, a rigidez e a institucionalização formal da vida, e os ideais estáticos e egoístas.” (p. 92)

Para Dewey, a coexistência em boa medida dos critérios por ele propostos caracterizam uma sociedade democraticamente constituída. Nasce daí o conceito de democracia, para Dewey: "Uma democracia é mais do que uma forma de governo; é, essencialmente, uma forma de vida associada, de experiência conjunta e mutuamente comunicada." (ibidem, p. 93) 
Desenvolvendo mais estes critérios em relação à sociedade democrática. Em relação ao primeiro critério - interesses comuns compartilhados - a sociedade amplia em quantidade e variedade os pontos de participação e, mais importante ainda, aumenta a confiança no reconhecimento de que tais interesses recíprocos são os que devem servir de direção e controle social. Interesse comum, na explicação deweyana, significa a necessidade de cada indivíduo pautar suas atividades tendo em vista as ações dos outros e levar em conta estas condutas para orientar e dirigir as suas próprias. A extensão para o maior número de indivíduos a que este critério se aplica, considera Dewey, "equivale à supressão daquelas barreiras de classe, raça e território nacional que impedem que o homem perceba toda a significação e importância de sua atividade." (ibidem, p. 93) O segundo critério - interação e reciprocidade cooperativa com outros grupos - subentende que a sociedade democrática torna possível a cooperação mais livre entre os grupos sociais e desenvolve os hábitos sociais necessários ao processo de adaptação contínua, tendo em vista a necessidade de ajustamento às novas situações criadas pelos intercâmbios.

Quantidade e variedade de intercâmbio proporcionam a diversidade de estímulos para o indivíduo reagir, variar seus atos, liberando energias que ficariam reprimidas numa convivência em grupo fechados e restrições inibidoras.

Dewey identifica que as características da sociedade democrática são fruto do desenvolvimento da indústria, comércio, migrações, intercomunicação e resultado do domínio das energias naturais pela ciência. A continuidade e ampliação da vida social democrática dependem do esforço voluntário. Mas isto somente se consegue com a educação. Desta forma, a democracia e educação constituem o equilíbrio da balança da vida social. Uma educação deliberada e sistemática é mais condizente com a comunhão democrática em que os interesses se interpenetram e se regulam mutuamente proporcionando progresso ou readaptações. Uma sociedade democrática somente será eficiente se a vida associada dos concidadãos for uma experiência onde os significados são construídos e comunicados numa ação conjunta. Repudiando a autoridade externa, política e intelectual, governantes, líderes e cidadãos regulam suas ações a partir dos critérios da democracia. Daí ser a democracia um princípio que como forma de vida a afetar completamente o ser humano

A idéia de democracia é mais ampla e mais completa do que sua possíveis aplicações nos mais felizes dos casos. Para ser realizada, ela deve afetar todos os modos de associação humana: família, escola, indústria, religião. E mesmo no que tange a arranjos políticos, as instituições governamentais são apenas um mecanismo de fixar numa idéia canais de operação efetiva. (Dewey,1991c, p. 148) 
A concepção democrática deweyana está apoiada no princípio de continuidade entre a experiência e a natureza, conforme analisamos. É incompatível com dualismos da filosofia tradicional centrada no paradigma da representação, ou seja, a concepção na qual uma idéia verdadeira é aquela que coincide com a imagem ou cópia mental dos objetos.

A sociedade democrática é a única capaz de permitir a livre e necessária comunicação da experiência entre os indivíduos proporcionando a continuidade da vida social. A sociedade democrática é o espelho do próprio organismo humano:

A democracia não pode ser concebida como alo inerente a alguma seita ou raça, tampouco a alguma apoteótica forma de governo já sancionada e consagrada. É tão somente um nome a identificar a verdade segundo a qual a natureza humana se desenvolve somente quando os elementos tomam parte na direção das coisas que são comuns, sociais, coisas pelas quais os homens e mulheres formam agrupamentos familiares, sociedades comerciais, governos, igrejas, associações científicas, etc. (Dewey, 1959a, p. 203)

Para sobreviverem, os seres humanos têm que estar em contínua interação com o ambiente (escala biológica) e, para continuar vivendo como tais no ambiente específico do social precisam manter-se em comunicação com os outros membros da espécie. Para sobreviver precisam se associar e cooperar: "Sobrevivência humana, significa sobrevivência social, e esta significa ação fruto do pensamento inteligente do homem.” (Amaral, 1990, p. 68)

A própria inteligência tem origem na cooperação social, conforme pensa Dewey: “[...] inteligência é um bem, um ativo social que se reveste de função tão pública quanto é, concretamente, sua origem na cooperação social.” (Dewey, 1970, p. 77) A inteligência é o instrumento socializador por excelência e adequado para atuar com eficácia no sentido de restabelecer a continuidade da experiência. (cf. Amaral, 1990, p. 90).

A cooperação social é uma necessidade natural, inata para a sobrevivência do ser humano e se manifesta nas demandas por companhia, emulação, organização para atingir fins comuns, expressão e manifestação estética, a necessidade de governar, etc. (cf. Dewey, 1946, p. 184) A inteligência nasce e se desenvolve a partir desta condição humana e se torna um poderoso recurso para a vitalidade social. É o recurso que a raça dispõe como mediador dos conflitos: "A condição efetiva para a integração de toda divergência de fins e de todos os conflitos de crenças está em nos darmos conta de que a ação inteligente constitui o único recurso definitivo da humanidade, em qualquer campo.” (Dewey, p. 76, p. 252) A ação inteligente só é possível se houver essa estrutura social sensível aos conflitos sociais e que permite a investigação pública dos modos de resolver os conflitos. Desta forma as crenças 
adquirem valor e a experiência individual pode adquirir significações universais, ao se integrar ao todo da sociedade e nela se imortalizar. Por sua vez, a inteligência está sempre em crescimento:

Não é a inteligência uma coisa que se adquire de uma vez e para sempre. Ela está em constante processo formativo, e sua conservação requer constante alerta na observação das conseqüências, requer um espírito compreensivo empenhado em aprender, bem como uma coragem decidida a promover reajustamentos. (Dewey, 1958, p. 109)

Se a inteligência está em crescimento, dentro das fragilidades históricas, na mesma via estão a liberdade ${ }^{31}$ e a democracia. Para Dewey:

A liberdade que é essência da democracia é, sobretudo, a liberdade de desenvolver a inteligência; [...] Em qual extensão nós somos realmente democráticos será, no final, decidido pelo grau pelo qual as ameaças totalitárias existentes despertam-nos para a mais profunda lealdade à inteligência pura e indefinida, e às intrínsecas conexões entre ela e a livre comunicação: o método da conferência, consulta e discussão no qual elas tomam lugar, a purificação e a associação dos resultados líquidos das experiências da multidão de pessoas. (Dewey, 1941, p. 276)

Falar em inteligência é falar no método da inteligência ou da investigação, que é o do pensamento reflexivo, correspondente ao método científico. $\mathrm{O}$ método da ciência experimental e cooperativo é assimilado por Dewey como modelo geral da investigação, isto é, como sendo o próprio método da inteligência investigativa, que se diferencia das formas empiristas e racionalistas. Como o método da ciência é um poderoso instrumental de controle, criado pela inteligência humana, ele se constitui num desafio para ser utilizado na solução dos problemas referentes aos assuntos humanos. Dewey atribui um caráter verdadeiramente social à ciência: a investigação é coordenada e deve ser pública para se comprovar mutuamente as observações; ela promove o bem-estar físico e mental. A máxima importância dessa função social da ciência pode ser ilustrada pela sua função na atividade humana do trabalho: "A principal oportunidade para a eficácia da ciência será a descoberta das relações do homem com seu trabalho - inclusive as relações com os demais que nele tomam parte - para que o

${ }^{31}$ Liberdade é, para Dewey, um conceito essencialmente social e intrinsecamente ligado à inteligência. Sua definição é assim expressa: "liberdade não é precisamente uma idéia, um princípio abstrato. É poder, poder efetivo de fazer coisas específicas. Não existe liberdade em geral; liberdade no sentido amplo. Se alguém quiser saber qual a condição da liberdade em um determinado momento, alguém tem que examinar o que as pessoas podem fazer e o que não podem fazer." (Dewey, p. 1946, p. 111) 
trabalhador ponha o seu interesse inteligente naquilo que estiver fazendo." (Dewey, 1979, p. 91)

O sistema democrático é o que oferece as melhores possibilidades para o desenvolvimento da inteligência, uma vez que ele torna possível a ação compartilhada, a cooperação, a experiência inteligente investigativa. Os sistemas autoritários repelem a atividade reflexiva, diz Dewey: "Onde quer que impere a autoridade, o pensamento é tido como duvidoso e nocivo." (Dewey, 1958, p. 144) Por sua vez, o método da inteligência é o método que alimenta a democracia, e portanto, seria útil estar presente na educação para formar os hábitos investigativos e para que o pensamento se torne reflexivo. Desta forma, deve se constituir num princípio educativo a ser adotado como objeto da conduta, desta atitude mental, da formação do hábito do pensamento reflexivo.

A democracia tem significado moral e ideal como confirma Dewey: "Temos de ver que democracia significa a crença de que deve prevalecer a cultura humanística; devemos ser francos e claros em nosso reconhecimento de que a proposição é uma proposição moral, como qualquer idéia referente a dever ser.” (Dewey, 1970, p.212) Esta crença tem sua base no princípio de que a inteligência é um bem, um ativo social que se origina na cooperação social e tem função pública:

[...] a democracia tem significação moral e ideal, é porque se exige de todos uma retribuição social e porque se proporciona, a todos, oportunidade para o desenvolvimento das suas aptidões distintivas. O divórcio dos dois objetivos na educação é fatal à democracia; a adoção da significação mais restrita de eficiência priva-a de sua justificação essencial. (Dewey, 1979b, p. 133)

Decorre daí o valor capital que tem a educação no sentido que proporciona a todos aquinhoarem-se dos benefícios sociais e desenvolverem suas aptidões individuais, e exige, também, de todos retribuição social. Da mesma forma, a reflexão da filosofia sobre as necessidades humanas na luta pela sobrevivência deve ser regida pelos fins e valores democráticos para a garantia dos mesmos. A filosofia deverá ser o corolário da democracia.

Childs explicita melhor a qualidade moral da sociedade democrática conforme Dewey: "para Dewey, uma sociedade democrática é uma sociedade organizada deliberadamente para ministrar medidas sociais, econômicas, políticas e governamentais que expressem e sustentem esta autoridade moral." (Childs, 1956, p. 128) Agindo desta forma, o caráter moral da sociedade democrática, somente acontece através do autogoverno: "Aquele tipo de autoridade moral denota um sistema de autogoverno, no qual as atividades se realizam 
sob autoridades que o povo formou e sancionou e aos quais obedece voluntariamente. (Childs, 1956, p. 128)

J. Campbell analisa a filosofia deweyana e a considera como uma filosofia da reconstrução social. "A filosofia pragmática de John Dewey e de outros pragmatistas sociais, especialmente George Herbert Mead e Jamos Hayden Tufts, é, em sua natureza, uma filosofia da reconstrução social.” (Campbell, 1995, p. 144) A reconstrução social ocorre de acordo com o método propugnado por Dewey. O método opera em dois níveis distintos. "O primeiro nível é o da formação dos problemas e seleção e desenvolvimento de soluções potenciais." (Campbell, 1995, p. 149) Neste sentido, o método pode ser útil para resolver os mais variados tipos de problemas. Campbell coloca que, no caso de solução de problemas, "é necessário pensar diferentemente, e os membros da sociedade com aprimorada experiência podem ser particularmente úteis em formular problemas e sugerir possíveis soluções." (Campbell, 1995, p. 149) A reconstrução de conceitos seria a tarefa primária do filósofo, embora não exclusiva. O segundo nível, diz Campbell é "o teste público e avaliação das idéias e propostas, que os expertos e outros colocaram, e a sanção daqueles que sofrem o efeito." (Campbell, 1995, p. 151) Neste caso, para resolver o problema, diz Campbell, "é necessário agir diferentemente assim como, criar, eliminar e modificar instituições." (Campbell, 1995, p. 151) Considerando o funcionamento do método na sociedade democrática, Campbell afirma: "Numa democracia, é trabalho da comunidade determinar se as soluções sugeridas para ela pelos especialistas são adequadas para resolver os problemas que são reconhecidos." (Campbell, 1995, p. 151) 


\section{CAPÍTULO IV}

\section{CONCEITO E EDUCAÇÃO}

\subsection{Educar e conceituar}

O conceito tem importância fundamental na filosofia pragmatista deweyana uma vez que ele é o instrumento pelo qual a inteligência desenvolve as significações lógicas necessárias para a continuidade da experiência ou da vida. Este instrumento permite operar com as significações e dados no processo dúvida-investigação. Ele torna viável e enriquece o modo de vida democrático através da linguagem e comunicação. Como vimos, Dewey tece relação recíproca, mútua e vital entre conceito, investigação, democracia e educação. A democracia não é uma via fácil de se alcançar e seguir, ela é a mais difícil de todas conforme o autor argumenta. Ela tem significado moral e ideal por ser a via de crescimento individual e social. Neste sentido, é a mesma via da investigação e da educação. Apresentamos o excerto a seguir para retratar como o professor Dewey estabelece a relação entre estes conceitos e a razão pela qual se empenha nesta tarefa:

Eu tenho me esforçado em chamar a sua atenção, primeiro, para a inerente, vital e orgânica relação que existe entre democracia e educação por dois lados: pelo lado da educação, das escolas e pelo lado do significado real da democracia. Eu tenho simplesmente tentado dar um certo número de ilustrações mais ou menos ao acaso, de qual é o problema das escolas de hoje, com referência à preparação da juventude do país para a participação ativa, inteligente na construção e reconstrução e no eterno reconstruir porque, como eu disse, nunca pode ser atingido de uma vez por todas - da sociedade genuinamente democrática. E eu desejo fechar (assim como iniciei) dizendo, sobretudo, que a causa de democracia é a causa moral da dignidade e do valor do indivíduo. Através do respeito mútuo, da mútua tolerância, do dar e receber, da associação das experiências, ela é, enfim, o único método através do qual o ser humano pode ter sucesso em levar adiante este experimento no qual nós estamos todos engajados, queiramos ou não, o grande experimento da humanidade - o de viver juntos de modo que a vida de cada um de nós seja pelo menos vantajosa, no mais profundo sentido da palavra, vantajosa para si mesmo e que contribua para a construção da individualidade dos outros. (Dewey, 1946, p. 33)

O processo da formação do conceito é nuclear para a noção de experiência em Dewey. Sem a conceituação a experiência perderia completamente sua possibilidade de crescer, ampliar e ser transmitida, portanto, de ser educativa. E educação é vida, é a própria vida. 
Como guia para algumas incursões nas questões educacionais de seu pensamento, vejamos como Dewey defende o cuidado com o tratamento conceitual no trabalho pedagógico de desenvolvimento da lição:

[...] em toda fase de desenvolvimento, cada lição, para ser educativa, deveria conduzir a uma certa dose de conceptualização de impressões e idéias. Sem essa conceptualização ou intelectualização, nada se ganha que possa contribuir para uma melhor compreensão de novas experiências. (...) tal intelectualização é o depósito de uma idéia, definida e geral a um tempo. Educação, em seu aspecto intelectual, e obtenção de uma idéia do que é experimentado são expressões sinônimas. (Dewey, 1979a, p. 155/6, itálicos do autor)

O desenvolvimento da lição, ou a experimentação, é uma prática do próprio método da inteligência ou método do pensamento reflexivo, ou ainda, a lógica da investigação. Mas isso somente tem sentido se considerarmos a vida em crescimento, ou aprendizagem.

Dewey compreende a educação como uma experiência de vida, que acontece nas condições naturais e reais, na medida em que desencadeiam o processo reflexivo, ou processo da conceituação. Entende que a imaturidade da criança constitui poder para o crescimento, decorrendo daí o critério moral presente na sua fórmula de "aprender a aprender". Desenvolver o hábito de pensar é oferecer condições mais ricas para captar as influências do meio, tirar as que são mais vitais para estabelecer a continuidade com este meio, reagindo de forma mais satisfatória e mais vantajosa.

A educação concebida por Dewey trata das condições ambientais e humanas que promovem o mais rico e intenso desenvolvimento das necessidades naturais e sociais: as de ordem física, como alimentação, movimento, etc.; as de ordem psicológicas, como a necessidades de entender as emoções e significar as experiências; as ordem propriamente sociais, como a companhia, participação dos grupos e instituições; as de ordem cultural, como a estética, etc.; as de ordem política, como a vida democrática; as de ordem diretamente educacionais, como os objetivos, a escola, os professores e alunos, os métodos.

Ao pensar as questões da educação, das quais somente pudemos elencar algumas, Dewey faz filosofia da educação. Vejamos os diversos aspectos da teoria educacional deweyana. 


\subsection{Educar e a continuidade da vida}

A formulação mais geral que Dewey elaborou é que Educação é vida. Em cada um de seus escritos esta questão aparece desenvolvida sob formas diversas, talvez como a própria diversidade da vida.

No início da obra Democracia e Educação, Dewey retoma a idéia de vida como "toda experiência do indivíduo e da espécie" da qual fazem parte os costumes, instituições, crenças, vitórias e derrotas, divertimentos e ocupações (cf., Dewey, 1979b, p.2) Indivíduo e espécie fazem parte de uma unidade integrada e dinâmica.

O que é característico da vida e de toda experiência é sua continuidade pela renovação. A renovação não acontece de forma automática. Ela é obra da necessária tarefa da educação: "A educação, em seu sentido mais lato, é o instrumento desta continuidade social da vida." (Dewey, 1979b, p.2) Ela faz para o organismo social o que o alimento e a reprodução para o organismo (biológico).

A educação é ainda mais necessária numa civilização em que o progresso distanciou as condições naturais do organismo com vida social e cultural. Para haver continuidade da vida em formas mais complexas - biológica e cultural - é necessário haver formas de transmissão. A comunicação é o meio pelo qual se dá esta transmissão e a auto-renovação do grupo A continuidade da sociedade, diz Dewey, não se dá somente pela transmissão e comunicação, mas há identidade com estas duas formas. Viver em comunidade é ter coisas (crenças, conhecimentos, objetivos, etc.) em comum, o que somente é possível pela comunicação. Vida social e comunicação são uma mesma via de mão dupla cognominada de educação:

Não só a vida social se identifica com a comunicação de interesses, como também toda a comunicação (e, por conseguinte, toda a genuína vida social) é educativa. Receber a comunicação é adquirir experiência mais ampla e mais variada. Participa-se assim do que outrem pensou ou sentiu e, como resultado se modificará um pouco ou muito a própria atitude. E, deste efeito não fica imune aquele que comunica. (...) Por conseqüência, pode-se perfeitamente dizer que, para aqueles que dela participam, toda a prática social que seja vitalmente social ou vitalmente compartilhada é por sua natureza educativa. (Dewey, 1979b, p. 5-6)

No obra My Pedagogic Creed, já em seu primeiro artigo, Dewey havia colocado esta questão explorando a relação do indivíduo com a sociedade. "Toda educação procede pela participação do indivíduo na consciência social da raça." (Dewey, 1940, p.3). Dewey levanta os dois aspectos do processo educacional, que permeará toda sua obra: o psicológico e o 
social: "Este processo educativo tem dois aspectos: um psicológico e outro social, e nenhum deles pode ser subordinado ao outro, nem descuidado sem produzir conseqüências danosas." (Dewey, 1940, p.4). A relação entre estes aspectos é orgânica, não podem ser tomados dualisticamente, nem sobrepostos. Isto porque o indivíduo não está dividido em duas esferas, mas é concebido como ser ativo nas relações sociais. Já discutimos esta união orgânica do indivíduo constituindo a sociedade. $\mathrm{O}$ processo tem que ser conduzido organicamente: Os instintos, capacidades, tendências, estruturas psicológicas e experiência do indivíduo constituem o material são ponto de partida da educação; a cultura e condições sociais corroboram para interpretar as capacidades do indivíduo. "Estes poderes, interesses e hábitos devem ser constantemente interpretados: devemos saber o que significam. Devem ser traduzidos em termos de seus equivalentes sociais: em termos do que são capazes no sentido do serviço social." (Dewey, 1940, p.6).

\subsection{Educar na escola, viver socialmente}

A escola é uma invenção e construção humana, histórica e culturalmente determinada. Ela constitui um ambiente ou meio, implícito na sua designação "instituição social". Dewey explica a conotação destas palavras: "A palavras 'ambiente" e "meio" denotam alguma coisa mais do que o lugar em que o indivíduo se encontra. Indicam a particular continuidade entre o meio e as próprias tendências ativas do indivíduo." (Dewey, 1979b. p. 12) A vida não pode ser apreendida como existência passiva, mas modos de proceder e agir em um meio, que por sua vez influi sobre estas atividade.

A escola é um ambiente especial de vida por ser vida comunitária. Diz Dewey: "Sendo a educação um processo social, a escola é simplesmente aquela forma de vida em comunidade na qual estão concentrados todos os meios mais eficazes para levar a criança a participar dos recursos herdados da raça e utilizar suas próprias capacidades para fins sociais." (Dewey, 1940, p. 6)

A importância que Dewey dá é grande, quando se pensa a educação. Assim ele afirma que a educação sempre é uma prática indireta, através do ambiente: "o único processo de influírem os adultos sobre a espécie de educação que o imaturo recebe é o de influírem sobre o meio em que eles agem e, portanto, pensam e sentem. Jamais educamos diretamente e, sim, indiretamente, por intermédio do ambiente." (Dewey, 1979b. p.20) Por isso, coloca em 
ênfase a escolha intencional do meio, como ação causal para o fim correspondente. Regulando o meio pode-se obter o efeito educativo.

A escola como órgão social é este meio preparado para influir na direção mental e moral dos educandos. Neste sentido, ela cumpre seu papel na medida em que desempenha as seguintes funções:

Proporcionar um ambiente simplificado da vida social existente. Diante de uma civilização complexa não é possível assimilar as funções e tradições na sua totalidade. Entendendo o assimilar, no sentido de participar como forma de apreender a significação. Faz-se necessário selecionar os aspectos mais fundamentais - materiais e metodológicos estabelecer a progressão e coordenar os elementos que se quer desenvolver.

Criar um ambiente purificado para a ação, eliminando os aspectos desvantajosos que influenciam sobre os hábitos que se quer formar. Simplificar e depurar o ambiente dos fatores indesejáveis, escolher e idealizar o melhor para usar tendo em vista sua importância para a sociedade presente e futura que se almeja.

Criar um ambiente mais amplo, vasto e equilibrado com a variedade de raças, costumes, religiões, culturas, tornando a experiência mais rica do que a aquela restrita a ao meio em que o imaturo vive.

Como os imaturos convivem em ambientes com diferentes códigos (família, rua, igreja, etc.) além da variedade de origens dos imaturos, a escola tem a função de coordenar estas diversas influências, fortalecendo e integrando.

\subsection{Educar e dirigir}

Dewey resgata o sentido etimológico da palavra educação, que é o processo de dirigir, conduzir, elevar. É um processo formador, modelador cujo resultado é: "modelar os seres na forma desejada de atividade social" (Dewey, 1979b, p. 11) Dewey acrescenta também as palavras controle e guia para conotar a educação. É preciso entender que não se trata de uma "energia" que atua do exterior, por coação ou compulsão. O ambiente fornece estímulos provocadores de respostas. Estas procedem do cabedal de experiências do indivíduo. A ameaça ou coação se pautam pelo medo e são inúteis. Neste caso, o problema passa a ser o domínio deste instinto. Recorrer a esta prática pode perverter a natureza humana, despertando instintos de astúcia e dissimulação e estimular atos piores. 
A direção tem dois aspectos complementares: por um lado exige focalizar o alvo fixando a ação já que os movimentos do imaturo são descoordenados como quem inicia uma atividade nova. Eliminam-se os movimentos desnecessários e desordenados. Por outro lado, exige-se coordenar os atos para que sejam sucessivos numa continuidade ordenada, ou seja, um ato prepara e gera o seguinte, dando equilíbrio para a ação em vista de seu fim.

A condição fundamental da direção é angariar a contribuição dos instintos e hábitos do imaturo de forma a dirigir com economia e sabedoria. Assim, a direção torna-se redireção. A modificação o rumo da ação acontece com o emprego das próprias energias do imaturo respondendo aos estímulos do meio.

Modos mais permanentes e influenciadores são os que atuam continuamente. Dewey comenta as situações em que uma pessoa se recusa, ou ameaça desobedecer, a fazer certa coisa que desejaríamos. Nestas situações acreditamos possuir uma força superior que regula e controla, como se o ato de levar um cavalo ao rio fosse suficiente para fazê-lo beber ou prender alguém fosse suficiente para o arrependimento. Este é um resultado físico imediato que não influi nos aperfeiçoamento mental, educativo. Há necessidade de fazer uma diferenciação, diz Dewey, entre resultados físicos e resultados espirituais ou educativos. Quando se confundem estas duas instâncias, perde-se a oportunidade de fazer a pessoa contribuir participando e redirecionando sua ação para o efeito visado, desenvolvendo convenientemente o espírito na direção adequada.

A questão é saber como proceder inteligentemente, quando impuser um resultado físico direto que não é aconselhado (vexame, censura, punição, ou mesmo o elogio como artimanha para mudar de direção) e, por outro lado, se ao consentir que o imaturo faça certas experiências lidar com o resultado que poderia ser muito inconveniente e prejudicial?

Dewey encontra a solução no argumento do meio social, como o agente constante e eficaz. Ora, o meio social poderá utilizar o meio físico como intermediário em ações consideradas pessoais a influírem sobre os outros, já que é impossível essa ação sem o meio físico. Exemplos deste caso são o sorriso, carranca, palavra de advertência ou estímulo.

Outra forma de influência mútua seria a associação para objetivos comuns, que implicam o uso conjunto das coisas como meios e como medida dos resultados pretendidos. Neste caso, Dewey retoma o argumento da origem da significação, ou seja, ela nasce com o uso característico que damos às coisas devido às suas qualidades particulares. A significação representa o ato mental, ou consciência do que se faz (uma resposta à coisa em sua 
significação) e não mera adaptação a um estímulo físico, ou seja, uma atividade sem direção, ação cega, inconsciente e não inteligente, porque sem conseqüiências previstas. Esta interação cria hábitos de adaptação externa. A primeira também é adaptação, mas ocorre pela reação em que a atividade está dirigida e regulada por algum plano de ação, algum fim em vista, uma significação. Os dois aspectos da significação para fins educacionais são:

[...] as coisas materiais não influenciam o espírito (ou formam idéias e convicções) exceto quando se associam à ação tendo em mira conseqüências previstas. O outro ponto é que uma pessoa só modifica o estado de espírito de outras por meio do emprego especial que faz das condições físicas. (Dewey, 1979b, p. 34)

A compreensão comum da vida social depende de "dar às coisas e aos atos a mesma significação." (Dewey, 1979b. p.32). O interesse pelos atos das outras pessoas relacionados aos seus atos torna a ação socialmente orientada. A fome e o choro de uma criança podem ser socialmente orientados e dirigidos inteligentemente quando a criança relaciona seu estado com a sequiência de atos que os outros fazem para a sua satisfação. A criança observa, reconhece um interesse comum e identifica seu próprio estado. Assim, a direção social é intelectual, consiste nos hábitos de inteligência previamente formados. Estes hábitos determinam as respostas que serão dadas no uso dos objetos em situações conjuntas ou compartilhadas. Portanto, a mente ou espírito adquirem o sentido de método de controle social:

A direção social consiste, realmente, nos hábitos de compreensão que se estabelecem, usando-se os objetos em correlação com outras pessoas, quer pela cooperação e auxílio, quer pela rivalidade e concorrência. $\mathrm{O}$ espírito ou a mente como coisa concreta, é precisamente o poder de compreender as coisas tendo em vista o uso feito das mesmas; um espírito socializado é a capacidade de compreendê-las tendo em mira o uso que lhes é dado em situações conjuntas ou compartilhadas. E mente ou espírito neste sentido é o método de direção social. (Dewey, 1979b, p. 35)

O principal instrumento através do qual se dá a direção social é a linguagem. Entretanto, ela terá melhor efeito se for empregada conjuntamente com o uso dos meios materiais: "Mas a linguagem não seria esse instrumento eficaz se não se sobrelevasse a usos mais grosseiros e tangíveis de meios materiais para a consecução de resultados que constituem as suas bases." (Dewey, 1979b, p. 35) 


\subsection{Educar e aprender a usar a linguagem}

Pela linguagem as coisas físicas foram transformadas, perdendo qualidades originárias e se transformando em instrumento social. $\mathrm{O}$ aprendizado da linguagem fornece um meio para ampliação da capacidade de aprender. É por meio da linguagem que a experiência é formulada ${ }^{32}$ em suas significações e se torna apta a ser comunicada. Ela tem grande papel como recurso para a educação:

Por meio dela, em caráter de substitutos, conseguimos participar largamente da passada experiência humana, dilatando e enriquecendo assim a experiência do presente. Achamo-nos habilitados, simbólica e imaginativamente, a antecipar situações. Por infinitos meios a linguagem condensa significações que registram resultados sociais e pressagiam perspectivas sociais. (Dewey, 1979b, p. 41)

O perigo do uso da linguagem é convertê-lo num instrumento de aprendizado passivo, de transmissão do conhecimento, um uso livresco e pseudo-intelectual. Esta prática apesar de condenada continua persistindo de forma tão arraigada. Coloca Dewey a questão: 'Que a educação não consiste unicamente em 'falar' e 'ouvir', e sim em um processo ativo e construtor, é principio quase tão geralmente violado da prática, como admitido na teoria (Dewey, 1979b, p. 41)

Preparar o meio escolar é oferecer local e condições para que o aluno possa fazer agir e utilizar instrumentos e materiais, prenhes de significado, com extensão ampla. Aparelhamento do ambiente com instrumentos para atividade conjunta e cooperativa. Os métodos e a administração devem ser modificados de forma a garantir a ocupação contínua do aluno com as coisas.

A educação é pensada a partir da atividade associada. Dewey questiona as formas educacionais que creditam o aprendizado a uma "ocupação conscientemente isolada." Trata-

\footnotetext{
32 Dewey desenvolve melhor a idéia de formulação da experiência da seguinte forma: "Esta formulação requer colocarmo-nos fora da mesma, vê-la como outra pessoa a veria, observarem-se os pontos de contato que ela tenha com a experiência pessoal da pessoa a quem vai ser comunicada, a fim de ser apresentada em tal forma que a pessoa lhe apreenda a significação. A não se $r$ que se trate de lugares-comuns, precisamos conhecer, imaginando-a, a experiência de outras pessoas, para compreensivelmente lhe falarmos sobre a nossa própria experiência. Toda comunicação é semelhante à obra de arte. “(Dewey, 1979b, p. 6)
} 
se de contrariar o próprio objetivo uma vez que não fornece o sentido social das suas aptidões, materiais e recursos que utiliza e que só pode ser adquirido numa atividade em conjunto.

O fim da educação, diz Dewey, é “conseguir esta direção interna por meio da identidade de interesse e compreensão.” (Dewey, 1979b, p. 43)

\subsection{Educar e crescer}

Dewey coloca que a criança ao nascer e nos seus primeiros anos de vida é totalmente dependente dos outros membros da espécie. A impotência da criança ao nascer para lidar com o ambiente físico para garantir sua sobrevivência é recompensada com uma "força compensadora", que é a sua capacidade social. A criança nasce com mais tendências instintivas do que os outros animais. Entretanto, os filhotes dos animais aperfeiçoam seus instintos com mais rapidez e eficiência. Estes animais se encontram em condições superiores em termos de habilidades iniciais, desenvolvendo-as com rapidez para se adaptar às condições físicas no início de suas vidas. Suas aptidões físicas compensam sua falta de aptidão social. Sobre o potencial social da criança Dewey afirma: "O mecanismo vital e inato da criança e seus impulsos, tudo contribui para facilitar a correspondência de natureza social." (Dewey, 1979b, p. 46)

Dewey se contrapõe aos que afirma existir um "egoísmo infantil". Este fato mostra "a intensidade e retidão com que as crianças se dirigem a seu alvo." (Dewey, 1979b, p. 47) Isto confirma o emprego do instinto social para um interesse próprio e não a inexistência deles ou o mero egoísmo. O que existe para Dewey é um "conflito de egoísmos", entre o da criança e o do adulto, pois, na percepção deste último, absorvido com suas preocupações, considera as preocupações das crianças "desrazoados desejos".

Esta dependência da criança expressa sua potencialidade mais do que sua fraqueza e no âmbito social subentende interdependência. A independência levada ao extremo na forma de insensibilidade aos demais faz decrescer a capacidade social do indivíduo.

O que caracteriza o imaturo é sua capacidade de se adaptar ao meio. A palavra que Dewey usa para esta capacidade é plasticidade, mas deve ser entendida no sentido de "aptidão de aprender com a experiência, o poder de reter dos fatos alguma coisa aproveitável para solver as dificuldades de uma situação ulterior." (Dewey, 1979b, p. 47) O indivíduo cria 
assim condições para modificar seus atos a partir de experiências prévias ou a capacidade de “desenvolver atitudes mentais”, base para a aquisição de hábitos. (Dewey, 1979b, p. 47)

Diferentemente de um animal cujo aprendizado está restrito a dominar com rapidez seu equipamento original para se adaptar ao meio, uma criança tem a vantagem da multiplicidade de reações instintivas para tentar, e somada ao acúmulo da experiência. Sobre sua capacidade para aprender Dewey afirma:

O aprender a prática de um ato, quando não se nasce sabendo-o, obriga a aprender a variar seus fatores, a fazer combinações sem conta deste, de acordo com a variação das circunstancias. E isso traz a possibilidade de um contínuo progresso, porque, aprendendo-se um ato, desenvolvem-se métodos bons para outras situações. Mais importante ainda é o fato que o ser humano adquire o hábito de aprender. Aprende a aprender. (Dewey, 1979b, p. 48)

Como a vida social se torna cada vez mais complexa, o processo de aquisição também sofre interferência. Assim, justifica-se aos olhos de Dewey, o prolongamento do período da infância, favorecendo a aquisição dos "variados e novos modos de controle" que contribuem para o progresso social

A concepção de imaturo para Dewey tem sentido pleno, quando relacionada à noção de crescimento ou desenvolvimento e um sinal deste é a formação de hábitos. Por outro lado, a concepção de educação subentende também desenvolvimento. Estes conceitos guardam estreita relação com a vida. Daí conclui Dewey: "Vida é desenvolvimento e o desenvolver-se, o crescer, é vida." Duas implicações decorrem para a educação: "1) que o processo educativo não tem outro fim além de si mesmo; e que 2) o processo educativo é um contínuo reorganizar, reconstruir, transformar.” (Dewey, 1979b, p. 53)

O desenvolvimento é a orientação das energias e forças latentes para formação de hábitos, e, especificamente, isto envolve "habilidade executiva, interesses definidos e certos e objetivos específicos para a observação e reflexão" (Dewey, 1979b, p. 53) Porém, tal orientação não deve inibir as aptidões especiais da criança: A criança é possuidora, por certo, de aptidões especiais: desprezar esta circunstância é mutilar ou deformar os órgãos de que depende seu desenvolvimento.

A crítica de Dewey dirige-se àquelas interpretações de desenvolvimento como tendo um fim fixo. Por outro lado, a instrução significa o método de suprir esta falta pelo "depósito de conhecimentos num vazio mental e moral, que aguardava a ocasião de ser preenchido." (Dewey, 1979b, p. 55) 
Dewey compreende o desenvolvimento como sendo em si o seu próprio fim. Nesse sentido, tanto a criança quanto o adulto estão em desenvolvimento e este é um processo com fim em aberto.

Daí decorre que sustentar a idéia de desenvolvimento é sustentar que ele proporciona mais desenvolvimento, e a educação se subordina a mais educação. Isto significa dizer que, em qualquer tempo, a vida tem qualidades próprias. A educação tem significado enquanto organiza as condições para que o indivíduo possa utilizar as qualidades inerentes à vida, assegurando crescimento e desenvolvimento. Educação não é um empreendimento que se preocupa com o trajeto da vida de uma idade a outra - criança ao adulto - mas que, em qualquer idade, a vida apresenta potencialidades que podem desabrochar, isto é, o crescimento é contínuo, por isso, vida é o próprio crescimento. Idealizar uma infância ou a vida adulta é para Dewey uma "ociosa fantasia". (cf. Dewey, 1979b, p. 55) O olhar de Dewey para a criança, ao compreendê-la com os conceitos de imaturidade e crescimento, ou desenvolvimento, é que nenhum sinal da infância nega o princípio da vida, que é o crescimento. Mas, crescimento só se efetiva quando converte estas energias, que se manifestam em diversas direções, às vezes sob a superficial designação de peraltice e indisciplina, num desejo de desenvolvimento contínuo. Por isso, Dewey recorre a Emerson, que alerta sobre a importância do respeito integral pela natureza, que necessita ser amparada pelo conhecimento ou cultura, para realizar suas inclinações: "Respeitai a criança, respeita-a até o fim, mas respeitai-vos a vós mesmos...” (Emerson apud Dewey, 1979b, p. 56)

Tal respeito significa que o trabalho de educar consiste em proporcionar os meios para a natureza se desenvolver, meios que somente se consegue vislumbrar pela reflexão.

(...) é ser o intuito da educação escolar assegurar a continuação da educação, coordenando as energias e organizando as capacidades que asseguram o permanente desenvolvimento. A tendência a aprender-se com a própria vida, e a tornar tais as condições da vida que todos aprendam com o processo de viver, é o mais belo produto da eficiência escolar. (Dewey, 1979b, p. 55)

\subsection{Educar e reconstruir a experiência}

Para Dewey o problema das teorias sobre educação é que elas desviam a atenção da questão nuclear da vida, que é a reconstrução da experiência em curso, e são unilaterais ao colocar o fim da educação em objetos e tempos remotos e fixos. Embora afirmem a idéia de desenvolvimento, ora tendem para um desdobramento de faculdades latentes, concebendo a 
formação do interior para o exterior, ora o seu inverso a formação do espírito fica a cargo do poder dos conteúdos, ora como repetição do passado. Suas explicações se complicam em toda espécie de dualismos - matéria e espírito, presente e passado, professor e aluno, etc. - que rompem com o princípio da continuidade.

Rompendo com estas idéias, Dewey vê a educação como tendo sempre um fim imediato, que é aumentar o valor do viver com novos significados, transformando a qualidade da experiência, independente de idade. Suas considerações são:

A infância, a adolescência, a vida adulta - tudo fica no mesmo nível educativo, no sentido de que aquilo que realmente foi aprendido em todos e em cada um dos estágios da experiência constitui o valor dessa experiência, e também no sentido de que a principal função da vida é, sob todos os pontos de vista, fazer que o ato de viver contribua para o enriquecimento de sua própria significação perceptível. (Dewey, 1979b, p.83)_p.76

A partir destes pressupostos, Dewey apresenta sua definição de educação: “... é uma reconstrução ou reorganização da experiência, que esclarece e aumenta o sentido desta, e também, a nossa aptidão para dirigir o curso das experiências subseqüentes.” (Dewey, 1979a p. 83, itálicos do autor)

O processo de reconstruir e reorganizar a experiência introduz as mudanças no ambiente natural e social. Esta mudança é em termos de conceitos ou de significações que são aumentados e ampliando a capacidade dos indivíduos de proceder "como custódios orientadores desta reorganização" (cf. Dewey, 1979b, p. 355) O mesmo processo permite, assim, que o indivíduo aprenda a se conhecer, além de conhecer o ambiente natural, social ou cultural.

A reconstrução e reorganização da experiência significam que o conhecimento e a compreensão somente podem ser obtidos através do fazer ou dos procedimentos experimentais e não meramente mentais. Diz Dewey: "Os homens, se quiserem descobrir alguma coisa, precisam fazer alguma coisa aos objetos, precisam alterar as condições destes. Esta é a lição do método do laboratório e a lição que toda educação deve aprender. O método do laboratório é a descoberta das condições sob as quais o labor e o trabalho podem tornar-se intelectualmente fecundos, e não meramente produtores de coisas exteriores. (Dewey, 1979b, p. 303)

A atividade educativa é aquela que produz sentido ou significação da experiência, ou seja, há percepção das relações, conexões e continuidades que antes não eram percebidas no que estivermos empreendendo. Estas relações passam a ser conhecidas, entendidas, ou seja, 
ficam fazendo parte do conteúdo intelectual. Desta forma, a experiência genuinamente educativa, ao oferecer conhecimentos e aumentar as aptidões "aumenta a capacidade de direção ou regulação das experiências seguintes.“ (Dewey, 1979a, p. 84)

Dewey diferencia a atividade educativa da atividade rotineira e caprichosa, ou atividades que se realizam sem objetivo, sem atenção consciente ou sob compulsão externa, ou ainda por força da obediência, ou de forma automática. Tais atividades desvinculam o resultado das ações realizadas e não favorecem a percepção das significações.

\subsection{Educar e ter objetivos}

Pensar a educação em uma comunidade democrática leva inevitavelmente a perguntar pela finalidade ou objetivos da educação. O primeiro critério para se chegar a aos objetivos: numa sociedade democrática exige-se que os fins sejam intrínsecos ao processo em que os indivíduos atuam, ou seja, que nasçam do livre desenvolvimento da experiência. Os objetivos da educação na sociedade democrática é tornar possível o constante desenvolvimento ou a contínua educação. Fins extrínsecos rompem à experiência, pois as relações sociais já não são eqüitativas na medida em que parte do grupo fica à mercê da imposição externa.

Por isso, interessa saber a natureza de um objetivo ou fim que se processa no interior da atividade. Uma primeira diferenciação importante, diz Dewey, tem que ser feita entre resultado e fim. A ação da energia sobre os corpos produz resultados, mas não necessariamente fins. $\mathrm{O}$ vento pode locomover areia ou terra, fazer dunas ou erosão. Este novo estado de coisas não é um fim, mas apenas um resultado. Objetivos ou fins dependem da natureza do resultado. O primeiro critério para saber se temos um objetivo ou fim em certo resultado é saber se há continuidade intrínseca. Diz Dewey: Um objetivo ou um fim importa em atividades seriadas e ordenadas, atividades cuja ordem consiste no progressivo completarse de um processo. (Dewey, 1979b, p. 110)

O segundo critério é saber se o objetivo ou fim previsto serve para dirigir os passos da atividade e não para relegar à condição de expectador contemplativo. Dewey explica o sentido do termo previsão, que se liga à observação, ordenação e seqüenciação dos meios e obstáculos em uma situação dada, oferecendo diversas alternativas para a escolha. Conforme Dewey explica: 
Primeiro, subentende cuidadosa observação das condições dadas, para ver quais os meios úteis para atingir-se o fim e descobrir os obstáculos existentes no caminho. Segundo, sugere a conveniente ordem ou seqüência na utilização dos meios. Facilita a seleção e os arranjos mais econômicos. Terceiro, torna possível a escolha entre diversas alternativas. Se pudermos predizer o resultado de procedermos deste ou daquele modo, poderemos comparar o valor de dois modos de proceder e formar juízos sobre sua relativa desejabilidade. (Dewey, 1979b, p. 110)

Conduzir a ação, de forma que haja continuidade entre meios e fins ou objetivos, para que a atividade se revista de um plano com intenção, propósito, direção e progresso, significa agir com inteligência. Daí a frase de Dewey: "agir com objetivo é o mesmo que agir inteligentemente." (Dewey, 1979b, p.111)

Os critérios que Dewey encontra para estabelecer adequadamente os objetivos são três. O primeiro critério é que o objetivo seja gerado pela ação da inteligência nos recursos e obstáculos das condições existentes, e não impostos, derivados ou fornecidos de uma fonte externa, que inibe a ação inteligente e livre; o segundo critério é o objetivo ter o caráter de esboço e, por isso, é plástico ou experimental, isto é, está sujeito a alterações necessárias para as devidas adaptações, evoluindo continuamente no curso da ação provando assim seu valor. Falando sobre o valor do objetivo, Dewey comenta: O valor de um legítimo objetivo reside, ao contrário, no fato de que podemos utilizá-lo para mudarmos as condições. (Dewey, 1979b, p. 113 /105) Neste sentido, é possível determinar um bom objetivo, que nasce da consideração séria da experiência aluno: Um bom objetivo, pelo contrário, é aquele que leva a observar a experiência atual do aluno, e, concebendo um esboço de plano de desenvolvimento dessa experiência, conserva este constantemente em vista, e modifica-o conforme as condições se apresentarem.

O terceiro critério diz respeito à "expansão e libertação de atividades” (Cf. Dewey, 1979b, p. 114). O objetivo é assim um "fim em vista", ou seja, é a presença de algo que determina e guia a ação. Desta forma, meios e fins cooperam para o crescimento da significação da experiência:

Cada meio é um fim temporário, até que o atinjamos. Cada fim, assim que atingido, torna-se um meio de transportar a atividade para mais além. Chamamo-lo fim quando marca a direção futura da atividade em que nos empenhamos - e meio, quando marca a direção atual. (Dewey, 1979b, p. 114-115)

Fins ou objetivos impostos são fixos, rígidos, estáticos e ocasionam a separação entre meios e fins. Afastam a significação que deveria servir de estímulo para a atividade. A falta 
de conexão do objetivo externo com a atividade atual o faz permanecer remoto e desarticulado com os meios que levariam aos fins. Restringe e limita a atividade.

Formular objetivos educacionais, para Dewey, é pensar nas mudanças a serem efetuadas diante das demandas das condições presentes. Os objetivos educacionais não têm nada de particular em relação aos objetivos de qualquer atividade: implicam "certas coisas a fazer, certos recursos com o que fazer e certos obstáculos a vencer”. (Dewey, 1979b, p. 115) O valor do objetivo está no auxílio à direção e desenvolvimento da atividade: é a aceitação da responsabilidade com o processo constante de observar, antecipar, escolher, elaborar planos e se dispor ao exercício da atividade. "Todo objetivo tem valor na medida em que auxilia a observação, a escolha e a elaboração de planos, hora a hora, instante a instante, quando nos dedicamos a alguma atividade". (Dewey, 1979b, p. 116) Perde o valor e utilidade quando se transforma em atividade de senso comum do próprio indivíduo.

Dewey alerta sobre o problema dos objetivos educacionais que são impostos externamente, como por exemplo, a ênfase na preparação para um futuro remoto resultando numa atividade mecânica e escravizada, tanto do professor como do aluno. Certos objetivos educacionais somente adquirem valor na medida em que municiam o educador com sugestões nos procedimentos da observação, antecipação, e utilização das energias a serem liberadas e dirigidas.

Os objetivos ou fins não são da educação em si, mas de alguém que pensa em certos fins relativos à aprendizagem em determinado tempo e local, de acordo com as mudanças que se processam. Por isso, eles são infinitamente variáveis, conforme se consideram as diferentes crianças, o crescimento de cada indivíduo e a própria experiência do professor.

Pode-se encontrar algumas características dos objetivos educacionais, diz Dewey. A base de um objetivo educacional é sempre o indivíduo, considerado intrinsecamente em suas atividades e necessidades concretas e atuais. As realizações do adulto oferecem um contexto amplo para se examinar as tendências dos alunos, mas se convertem em artificialismos se tomados como fins fixos. Outra característica dos objetivos educacionais é a sua conversão em um "método de cooperação", sugerindo meios para expandir e organizar as aptidões do aluno. O objetivo deve atender ao critério democrático: Enquanto não for reconhecido o critério democrático da importância intrínseca de toda experiência que se desenvolve, sentirnos-emos intelectualmente desnorteados pela exigência de adaptação a objetivos exteriores. (Dewey, 1979b, p. 118) 
A terceira característica é a posição crítica em relação a fins gerais e últimos,isto é, — de pôr-se em guarda contra. Significa dizer que o professor deve avaliar em que medida uma idéia geral proporciona a observação mais ampla de meios e recursos, de forma a descortinar o campo da atividade em curso e projetar luzes aos objetivos mais imediatos e concretos para se considerar as possibilidades destes. Assim, o valor educativo dos fins gerais e últimos está na própria recompensa imediata que oferece. E o critério para aferir o valor é, segundo Dewey, “a unidade ou integração da experiência” (Dewey, 1979b, p. 272)

A importância da concepção de um fim oferece mais liberdade para agir, segundo o autor:

Quanto mais completa for a concepção de alguém, das futuras realizações possíveis, menos sua atividade presente se sentirá manietada por um pequeno número de alternativas. Se uma pessoa tivesse conhecimentos integrais das coisas, poderia, quase, partir de qualquer ponto e manter-se em atividade contínua e frutiferamente. (Dewey, 1979b, p. 118)

\subsubsection{A eficiência social como objetivo da educação.}

As práticas que pervertem a eficiência social são aquelas que as atividades de alguns indivíduos se subordinam a prestar serviço exteriores a seus interesses e aptidões para os outros das classes que detém o poder, fomentando uma educação em conformidade com o status quo.

Procura mostrar a importância de desenvolver as capacidades individuais inatas, através de atividades que tenham significado social.

Um critério democrático exige que desenvolvamos nossas capacidades até nos tornarmos competentes para escolher e seguir nossa própria carreira. Viola-se este princípio quando previamente se tentam adaptar os indivíduos a determinadas profissões industriais, não escolhidas de acordo com as aptidões inatas exercitadas, e sim de acordo com a fortuna ou categoria social dos pais. (Dewey, 1979b, p. 130)

Isto porque as novas invenções geram rápidas mudanças no âmbito da indústria. Uma formação de especialistas poderia deixar o indivíduo desamparado quando novas tecnologias substituem as antigas.

Eficiência social é a possibilidade de enriquecer a experiência compartilhada: “(...) eficiência social é nada menos do que a socialização do espírito ou da inteligência, que contribua ativamente para tornar a experiência mais comunicável e para derrubar as barreiras das separações sociais que tornam os indivíduos impenetráveis aos interesses dos demais. 
Numa educação progressista, a prática procura "abolir os privilégios indevidos e as privações e, não, perpetuá-las.” (Dewey, 1979b, p. 131)

O principal ingrediente da eficiência social, diz Dewey, é a "inteligente simpatia ou boa vontade” (cf. Dewey, 1979b, p. 131) E define simpatia da seguinte forma: “(...) é alguma coisa mais do que um simples sentimento; é a imaginação consciente e cultivada daquilo que os homens têm em comum e a revolta contra tudo que desnecessariamente os divide. (Dewey, 1979b, p.132)

\subsubsection{Cultura como objetivo da educação}

A eficiência social é impossível sem a cultura. Cultura significa que alguma coisa foi tratada, amadurecida. Ela é também algo de pessoal, diz Dewey, no sentido de cultivar idéias, artes e valores humanos apreciáveis. Não se trata de algo "interior" que se manifesta no “exterior", pois estes sentidos revelam dualismos perigosos. O que Dewey quer dizer é que a cultura se forma no processo da experiência. Se os resultados de uma atividade útil aos outros não for acompanhada de uma experiência qualitativamente valiosa em si mesma ela cria uma falsa compreensão de cultura. Aquilo que é tido como cultura interior mostra-se como não relacionado às outras pessoas, não comunicável livremente. Daí decorre a conotação de pessoa: "Somos como pessoas aquilo que nos mostramos ser quando associados a outras pessoas, numa livre reciprocidade de dar e receber." (Dewey, 1979b, p. 133) E a melhor definição de cultura que Dewey formula é: "a capacidade de expansão contínua da quantidade profundidade de nossas percepções e idéias.” (Dewey, 1979b, p. 135)

\subsubsection{Educação e experiência}

Confundiu-se instrução com aquisição de conhecimento de forma direta pela energia da inteligência. $O$ aluno é um expectador que recebe conhecimento diretamente e não o que tem experiências de aprendizagem, um agente ou participante da ação. Aliás, é quase este o sentido lato da palavra "aluno". Esta noção dá origem ao dualismo mente ou espírito e corpo. O primeiro, puramente intelectual e cognitiva, o mundo das significações, e, o segundo, compreendendo os fatores físicos e a ação.

Uma educação pautada por este dualismo traz resultados negativos. O primeiro problema é que a ênfase na atividade mental implica como conseqüência o desprezo do corpo. 
Mas esta fonte de energia que é o corpo se manifesta de alguma forma: indisciplina, recalcamento, peraltices sem significação. A anormalidade da situação gera fadiga e tensão entre professores e alunos. Apela-se para práticas como premiações ou punições conforme o comportamento do aluno. Perde-se a rica oportunidade de uma educação que empregue responsável e harmoniosamente as aptidões do corpo como um todo e ofereça-lhe livre expansão.

A atividade corporal é compreendida dentro de um modelo mecânico, de repetição, adestrando órgãos do sentido ou músculos isoladamente, desprendido da percepção dos sentidos do que se faz. A técnica sensório-motora da leitura, por exemplo, ao se preocupar com o reconhecimento e reprodução das palavras desprendidas de sua significação, desenvolve hábitos de leitura que dificulta a compreensão do que se lê.

$\mathrm{O}$ aspecto intelectual também fica comprometido neste modelo dualista. O método de abordar as coisas dá importância exagerada às coisas, em prejuízo das relações e associações que permitiriam. O juízo e a percepção andam distantes um do outro. $\mathrm{O}$ pressuposto é a capacidade do espírito de compreender as coisas independentes de suas relações dadas pela percepção. Acredita-se que o raciocínio e julgamento executam competentemente as associações causais, semelhanças e classificações que formam os conceitos.

A conseqüência deste procedimento é que ele falseia e limita a percepção:

As palavras, fichas das idéias, são, entretanto, facilmente tomadas pelas idéias. E exatamente na proporção em que a atividade mental se separa de um interesse ativo pelo mundo, em que se separa do ato de se fazer alguma coisa e de se relacionar essa coisa com aquilo que se está sentindo, as palavras, os símbolos tomam o lugar das idéias. A substituição é tanto mais sutil quanto subsiste algum sentido, alguma significação. Mas, habituamonos facilmente a contentar-nos com um mínimo de sentido, e a deixar de notar quão restrita é nossa percepção das relações que dão às coisas as suas verdadeiras significações. Acostumamo-nos tão completamente a uma espécie de pseudo-idéia, de meia percepção, que não temos acordo de quanto é semimorta nossa atividade mental, e quanto mais penetrantes e extensas seriam nossas observações e idéias, se as formássemos em meio às condições de uma experiência vivificante que requeresse, de nossa parte, o esforço de pensar e o uso do raciocínio: fazendo-nos procurar as conexões das coisas com que nos ocupamos. (Dewey, 1979b, p. 157)

O erro desta prática intelectualista de meras fórmulas verbais provém, diz Dewey, do erro de "acreditar que se possam perceber as relações sem a experiência - sem a combinação do tentar e do sofrer conseqüências." (Dewey, 1979b, p. 1570, itálicos do autor) O valor da experiência para o aprendizado é de fundamental importância para Dewey: "uma onça de 
experiência vale mais do que uma tonelada de teorias, simplesmente porque é só pela experiência que qualquer teoria tem importância vital e verificável.” (Dewey, 1979b, p. 158)

A experiência da reflexão tem sua origem no fato do pensar atuar como parte no curso dos acontecimentos e operar com a finalidade de influir no resultado dos mesmos. A expansão do pensamento para interessar-se por outras coisas e formas de pensar depende da educação: "A reflexão subentende também interesse pelo desenlace - uma certa identificação simpática de nosso próprio destino, pelo menos imaginativamente, com o resultado do curso dos acontecimentos." (Dewey, 1979b, p. 161) Desta forma a reflexão tende a ampliar o horizonte de abrangência e considerar com mais interesse as questões da cultura: "Só aos poucos, e com o crescer do tempo de visão, por meio do desenvolvimento das simpatias sociais, o ato de pensar se expande, até incluir o que se acha além de nossos interesses diretos: fato este de grande monta para a educação.” (Dewey, 1979b, p. 161-162)

\subsection{Educar e o agir com interesse e esforço}

A filosofia da educação deweyana dá grande importância aos conceitos de interesse e esforço, porque demarca a qualidade e orientação que a vida toma. Dewey recorre à etimologia da palavra interesse que é "estar entre" e complementa: "Interesse marca a completa supressão de distância entre a pessoa e a matéria e resultados de sua ação: é a união orgânica da pessoa e do objeto.” (Dewey, 1959b, p. 97)

Dewey destaca, em sua análise, três aspectos do interesse. Em primeiro lugar, o interesse é ativo ou propulsivo, alguma coisa de motriz e dinâmica. O organismo vivo e desperto está em atividade ${ }^{33}$, ou seja, tem sempre alguma tendência ou direção. Interesse na sua condição primária é um impulso e este é seletivo e preferencial. Mesmo no campo dos conhecimentos técnicos (artes e ciências), o espírito é sempre movimentado por alguma coisa a que se pode chamar interesse. Psicologicamente, Dewey coloca o interesse nesses termos: "um interesse é primariamente uma forma de atividade própria do organismo; isto é, uma

\footnotetext{
${ }^{33}$ Para Dewey a atividade tomada em sentido lato, "abrange tudo que envolva crescimento de capacidade especialmente da capacidade de compreender o sentido ou a significação do que se faz." (Dewey, 1959, p. 139) Ele exclui toda ação por constrangimento externo ou imposição, ações de simples reação à excitação externo e as ações regidas pela força mecânica do hábito.
} 
forma de sua evolução ou crescimento, que se realiza através de tendências nascentes." (Dewey, 1959b, p. 100)

O segundo aspecto é a objetividade, ou seja, concretiza-se em alguma coisa e não se confunde com um simples sentimento. $\mathrm{O}$ interesse se prende a idéias, objetos, fatos, etc. Em terceiro lugar, interesse é ligação do eu com alguma coisa, por isso é pessoal e emocional, ou seja, é desenvolvimento e expressão do eu. Pode ser direto, quando a experiência é suficiente em si e por si, como é característico nas brincadeiras, jogos, apreciação estética, etc. Consequentemente existe o interesse indireto ou mediato. Ele nasce da percepção de novas relações dentro da experiência: "coisas indiferentes, ou mesmo repulsivas tornam-se muitas vezes interessantes, logo que percebemos as relações e ligações que fazem nascer e de que não tínhamos tomado consciência.” (Dewey, 1959b. p. 101)

Para Dewey, há continuidade em termos de crescimento entre interesse direto e indireto, e não uma divisão linear entre ambos. Conforme a atividade se torna mais complexa, ela envolve maior número de fatores, de forma que aquilo que era interesse imediato se transforma em interesses com fins mais remotos e valiosos. A atividade passa a exigir que a mente esteja atenta por mais tempo no objeto desejado e dispense maior atenção, sentido e valor aos passos intermediários. Desta forma, diz Dewey, "nossa atividade cresce em extensão e profundidade" (Dewey, p. 1959b, p. 117) Em outra passagem ele diz: “O interesse é normal e, educativamente, legítimo e digno de confiança, no grau em que a atividade que ele envolva ganhe crescimento ou desenvolvimento." (Dewey, 1959b, p. 118, itálicos do autor) Inversamente, o interesse ilegítimo é sintoma de parada no desenvolvimento da atividade. Há distração e dissipação de energia em reações desconexas, apreciadas isoladamente de uma atividade global e duradoura, próprias de uma vida fragmentada.

Quando há desenvolvimento na experiência, o interesse se expande dilatando o tempo de sua execução e enriquecendo a atividade. Desloca-se também o interesse trivial com fins ocasionais para atividades especializadas com interesses em si mesmas, tornando um interesse distintamente intelectual. Exemplifica essa mudança o desenvolvimento das crianças que passam de uma brincadeira de amontoar ou encaixar blocos para a montagem de uma estrutura de casa ou castelo, posteriormente à construção de brinquedos, ou o envolvimento com jogos e demais ocupações de trabalho podendo evoluir para uma atividade puramente teórica. É importante observar, até para não contradizer a teoria deweyana, que o interesse intelectual, inteligente não é algo que nasce no final deste processo de crescimento, mas o acompanha de forma subordinada e subsidiária. Observa Dewey que sua análise das 
atividades do bebê, criança, jovens e adultos busca mostrar que "inteligência - na forma de uma percepção clara dos resultados de uma atividade e de uma busca de meios de adaptação deve ser considerada como parte integral de tais atividades." (Dewey, 1959b, p. 153)

Esta íntima relação entre interesse e inteligência pode nos levar à relação do interesse com o conceito. O interesse é expressão dos conceitos (significações), que conduzem as escolhas e ações dos indivíduos. Neste sentido, é curioso notar a pergunta que Dewey coloca para se avaliar a situação em que um interesse é transferido: "Até que ponto esse recurso novo e novo motivo servem para interpretar, para pôr em relação o espírito com o material, em si desinteressante?” (Dewey, 1959b, p. 104) E na seqüência Dewey reformula o problema, reforçando a relação de meios e fins, que é o processo de construção do conceito: "O problema pode ser definido como um problema de meios e fins." (Dewey, 1959b, p. 104)

A educação que leva em conta a importância do crescimento do interesse constrói o processo começando pelo lado prático, pois este é o campo da percepção das relações de causa e efeito, princípio da ciência. Quando se espera um determinando fim, isto é, o interesse pelo efeito, a reflexão passa a se ocupar das condições de sua produção, ou seja, as causas. O interesse num plano final se reverte no interesse pelos passos intermediários. Diz Dewey: “o interesse no fim, absorve, satura e transforma o interesse pelos meios, dando-lhes novo valor e nova significação." (Dewey, 1959b, p. 104) Assim, a visão se alarga e a experiência passa a compreender um todo maior de interesse do indivíduo.

As considerações de Dewey sobre a condução da atividade de ensino partindo deste princípio é a seguinte:

A função dos educadores é organizar as condições de expressão dos interesses práticos, de tal modo que se desperte o desenvolvimento daquelas fases intelectuais da atividade, e, por esse meio, se prepare a transição gradual para o tipo de atividade teórica. (...) Sempre que o trabalho com instrumentos, - de jardinagem, de cozinha, etc., - for inteligentemente conduzido, será relativamente fácil transferir o interesse do plano prático para o da experimentação criadora. Neste caso, passamos a interessar-nos pelos problemas como problemas, e por pesquisa e aprendizagem com instrumentos para resolvê-los - o que define o interesse distintamente intelectual. (Dewey, 1959b, p. 154)

Erros pedagógicos decorrem da falsa concepção de interesse, que consiste em escolher a matéria ou conteúdo primeiro, para depois torná-la interessante. Neste caso, a seleção não leva em conta tendências e necessidades da criança e o método de ensino se reduz a artifícios externos de preparação do material desvinculado com a criança. Os métodos de despertar interesse recorrem ou à pedagogia sentimental, que consiste em rebuçar de açúcar a 
matéria, oferecendo prêmio, afeição, promoção ou recompensa imediata ou futura, ou à pedagogia disciplinar, que apela para castigos ou ameaças. O interesse se torna "indireto, mediato, transferido. (cf. Dewey, 1959b, p. 103)

O problema de tornar as coisas interessantes consiste em "descobrir a relação intrínseca entre a matéria ou o objeto e a pessoa, relação que passa, uma vez conscientemente percebida, a ser o motivo da atenção.” (Dewey, 1959b, p. 102) Por isso, em primeiro lugar, deve-se considerar as experiências, forças e necessidades da criança. Em seguida, propor atividades de apresentação cuidadosa e inteligente do novo material, de forma a haver identificação com a matéria, ou seja, apreciação das relações e valores.

O interesse é sinal de crescimento intelectual, pois revela a atividade da mente construção e reconstrução conceitual. A atividade conceitual, muitas vezes subjacente ao interesse, é promotora do desenvolvimento na medida em que exige operar com as relações de meio e consequiência na condução da experiência.

O interesse é a base para qualquer processo de aprendizagem, em qualquer etapa da vida. Ele é a força que gera o crescimento da experiência, desenvolvendo as capacidades que ali estão, exigindo cada vez mais para sua completa realização. Vemos assim o estreito nexo entre interesse e educação: "Educação é extrair do presente a espécie e a potência de crescimento que este encerra dentro de si." (Dewey, 1959b, p. 183)

\subsection{Educar e aprender a pensar}

A concepção de educação deweyana tem o pensar como princípio da aprendizagem. Pensar é o princípio educativo para Dewey. Afirmações como esta são freqüentes em seus escritos: "é evidente que a educação, quanto a seu lado intelectual, está vitalmente relacionada com o cultivo (cultivating) da atitude do pensar reflexivo, preservando-o onde já existe, e substituindo os métodos de pensar mais livres por outros mais restritos, sempre que possível. (Dewey, 1979a, p. 85, itálicos do autor). Com pequenos acréscimos ele declara: “[...] a educação consiste na formação (formation) de hábitos de pensar despertos, cuidadosos, meticulosos.” (Dewey, 1979a, p. 86, itálicos do autor)

Para designar esta educação voltada para formar o hábito de pensar reflexivamente, Dewey criou a fórmula “aprender é aprender a pensar”.(Dewey, 1979b p. 83.) Aprender a pensar é aprender a aprender, no sentido de aprender como construir ou produzir os conceitos, 
conhecimentos ou significações, que aumentam a eficiência na ação e ampliam a capacidade de aprender mais coisas sobre nós e o mundo em que vivemos, em novas situações. Outra consequiência que podemos tirar desta fórmula é que, pensar é o método de aprender:

Pensar é o método de se aprender inteligentemente, de aprender aquilo que utiliza e recompensa o espírito. Nós falamos, com bastante propriedade, em métodos de pensar, mas o importante a termos em mente, a este respeito, é que pensar é método, o método da experiência inteligente em seu curso. (Dewey, 1979b, p. 168-169)

Dewey salienta que a educação deve se servir das condições naturais e reais para desencadear o pensar reflexivo. A concepção de imaturidade da criança constitui uma capacidade ou poder para o crescimento, que é entendido como critério moral presente na sua fórmula de "aprender a aprender". Imaturo, porque tem que aprender as coisas por meio da inteligência, enquanto outro animal faz suas atividades instintivamente, ou com curto período de prática. O aprender se torna um hábito especializado de aprender, um amor ao aprender. Desenvolver o hábito de pensar é oferecer condições mais ricas para captar as influências do meio, tirar as que são mais vitais para estabelecer a continuidade com este meio, reagindo de forma mais rica, satisfatória e mais vantajosa.

Como Dewey desenvolve a concepção de pensar como método na educação? Dewey desenvolveu os traços mais gerais ou característicos do método de adquirir conhecimentos, tomando como referência a experiência reflexiva, conforme estudaremos a seguir.

O pensar está para a experiência assim como o sangue está para o corpo, em termos analógicos. Uma situação de experiência, em que a atividade seja contínua e de interesse do aluno, é o estágio inicial do pensar e da educação. Mas há que se resguardar o sentido da idéia de experiência com a qual Dewey trabalha: ação / fazer - reação - significação. Romper este processo levou as teorias filosóficas e educacionais a conceber a possibilidade de cultivar o pensamento separado da experiência e esta como algo presumido na vida do aluno. Dewey insiste nesse ponto: “é indispensável uma situação empírica atual para a fase inicial do ato de pensar.” (Dewey, 1979b, p. 168_153) Esta situação deve ser aquela que na própria vida do estudante é motivo de reflexão. Então o aluno terá "alguma coisa para fazer e não alguma coisa para aprender.” (Dewey, 1979b, p.169_154) Este fazer exige reflexão, perceber relações, trabalhar com as observações e como resultado teremos aprendizagem.

A segunda fase é composta por dois elementos importantes, nesta situação, para suscitar reflexão, e na qual o aluno irá fazer algo: primeiro que ela seja algo novo, incerto e com a qualidade de ser problemática, portanto, não rotineiro ou caprichoso; segundo, que ela 
esteja ligada aos hábitos dos alunos de forma que possa ser desenvolvida. Portanto, problemático implica ser algo intrínseco à experiência do aluno, servindo de estímulo e direção das observações e da reflexão, e não, algo simulado, imposto exteriormente, compulsório.

O questionamento que Dewey levanta é sobre o que se passa na sala de aula e o que se passa na vida de uma criança. A curiosidade e as perguntas das crianças fora de escola contrastam radicalmente com uma sala de aula, que exige ouvir, ler e reproduzir. Este abismo é que precisa ser preenchido:

Nenhuma melhoria da técnica pessoal do professor remediará totalmente este estado de coisas. Para se preencher essa lacuna é necessário mais material aplicável mais "estofo", mais instrumentos e aparelhos e mais oportunidades para se fazerem as coisas. E, quando as crianças estão interessadas em fazer coisas, e discutem a respeito daquilo que surge no curso desse fazer, verifica-se, mesmo com métodos educativos relativamente sem valor, que suas perguntas e investigações são espontâneas e numerosas, e as soluções propostas, variadas e engenhosas. (Dewey, 1979b, p.171)

Em resposta aos métodos que propõem falsos problemas, a resposta do aluno desviase da matéria e se concentra numa falsa aparência de satisfazer determinadas exigências do professor: "O aluno estuda, mas, sem disto ter consciência, os objetivos se seu estudo são as convenções e modelos do sistema escolar e da autoridade escolar, e não os 'estudos' em si mesmos." (Dewey, 1979b, p. 171)

A conseqüência é perversa porque a reflexão é artificial unilateral, criando um falso senso na formação do caráter.

A terceira fase importante na continuidade da experiência reflexiva é a que se ocupa com os dados, fatos, conhecimentos necessários para a análise e percepção do problema específico que deu origem a própria experiência. Estes dados são fornecidos pela observação cuidadosa dos fatos, pelo lastro de experiências anteriores que podem ser resgatados pela memória ou podem ser supridos por outras fontes como leitura, comunicação com outras pessoas, ou experiências alheias. Em sentido mais amplo, os conhecimentos acumulados historicamente pela humanidade constituem fonte fértil de dados para se empregar no problema e que vem, sobretudo, através da educação. Entretanto, uma educação voltada para o armazenamento na mente de conhecimentos de toda espécie a ser memorizado como um fim em si, e não como um fim visado, é hostil ao desenvolvimento educativo. Serve mais para embaraçar o espírito e desfocar seu fim, para uma prova artificial do espírito. Importante nesse caso é criar os meios para os alunos lidarem com esta fonte de dados. Por um lado, é 
produtivo tornar a dificuldade ampla o suficiente para mobilizar as forças do aluno para trabalhar com o conjunto de materiais disponíveis; por outro, um campo específico de dados acessíveis, claros e familiares para que juntamente com a situação confusa nasçam sugestões, que poderão ser úteis para a continuidade da reflexão. Trata-se de um trabalho para vigorar e treinar a inteligência para aprender a lidar com a bagagem de dados, discriminando o que pode ser útil para determinado problema. O erro de muitas abordagens educacionais é o de fornecer problemas e soluções prontas para o aluno: "Mas, o que é absolutamente inconveniente é que os outros, o livro ou o professor forneçam soluções já prontas, em vez de proporcionarem material, que o estudante haja de adaptar e aplicar por si mesmo à questão a resolver." (Dewey, 1979b, p.173)

A quarta fase da experiência reflexiva consiste no debruçar-se examinativamente sobre as idéias: sugestões, inferências, interpretações, suposições, explicações. Os dados recolhidos na fase anterior têm a função de definir e esclarecer o problema e não de resolvêlo. O pensamento precisa recorrer aos planos, á invenção à sagacidade que proporcione uma resposta possível. Nesta fase o pensamento busca construir uma hipótese de continuidade ou conexão entre algo a ser feito e a conseqüência que decorre, mas ainda não se apresentou. Trata-se, portanto, de encontrar elementos intermediários e não finais ainda:

Os dados despertam as sugestões, e só em relação com esses dados especiais é que podemos apreciar a propriedade das sugestões. Mas as sugestões, por outro lado, se projetam para além dos dados da experiência. Elas provêem resultados possíveis, coisas a fazer e, não, fatos (coisas já feitas). A inferência é sempre uma invasão ao desconhecido, um salto dado daquilo que é conhecido para o desconhecido. (Dewey, 1979b, p. 174)

A novidade que o pensamento produz consiste em relacionar as coisas familiares de maneira original, em um contexto não familiar. Praticamente todas as descobertas científicas, invenções e as produções da arte resultam deste processo.

Só as pessoas tolas identificam a originalidade com o extraordinário e o fantasioso; as outras reconhecem que a mesma consiste em dar às coisas ordinárias usos que ainda não haviam ocorrido a outras pessoas. É nova a operação, mas não são novos os materiais com que aquela é feita. A conclusão pedagógica a tirar-se disto é que todo o ato de pensar é original quando faz surgir considerações que ainda não tinham sido anteriormente apreendidas. (Dewey, 1979b, p. 174/5)

O mesmo processo se repete toda vez que uma criança descobre uma nova relação, mesmo sendo esta de amplo domínio humano. A descoberta contrasta radicalmente com uma justaposição maquinal, repetitiva. A experiência da descoberta significa que a experiência tem 
acréscimo genuíno e fica enriquecida com uma nova qualidade. É a produtividade mental da descoberta e criação que dá origem ao autêntico sentimento da alegria.

Com isso, Dewey estabelece um ponto central em sua teoria educacional: o estudo, o aprendizado através da experiência reflexiva é descoberta, e não armazenamento de conhecimentos de experiências alheias. Despejar conhecimentos na mente da criança, como se houvesse um aprendizado de idéias diretamente, é trabalho perdido: "nenhum pensamento ou idéia pode ser transferido como idéia de uma pessoa para outra." (Dewey, 1979b, p. 175) Isto porque, explica Dewey, a idéia que é dita constitui um fato para quem ouve e não idéia. Esta idéia não é algo vital, a não ser como uma lição ou uma exigência para passar num exame:

A comunicação pode servir de estímulo para a outra pessoa compreender a questão e conceber uma idéia semelhante, ou pode abafar seu interesse intelectual e aniquilar seu incipiente esforço para pensar. Mas aquilo que ela aprende diretamente não pode ser uma idéia. (Dewey, 1979b, p. 175)

Os próprios alunos tomam estas supostas idéias como conhecimentos inúteis e inertes. Dewey levanta duas conseqüências nefastas para a vida do estudante: "A experiência ordinária dos estudantes não adquire o enriquecimento que poderia ter; não é fecundada pelos estudos escolares. E as atitudes advindas, de costumarem-se a isso e de absorver material semicompreendido e semidigerido, enfraquecem o vigor e a eficiência mentais." (Dewey, 1979b, p. 177)

A posse de uma idéia vem na medida em que a pessoa trabalha reflexivamente com um problema como causa sua, vital, e que lhe cobra uma resposta. Os pais e professores podem oferecer condições que estimulem o pensamento e cooperar com a experiência conjunta, mas não pode assumir e resolver o problema por outro. Somente nesta condição haverá aprendizado. O que se pode fazer é proporcionar situações significativas na qual a atividade do aprendiz origine, reforce e prove as idéias, significações, relações percebidas. Neste sentido, Dewey destaca a posição do educador:

Isto não quer dizer que o docente fique de lado, como simples espectador, pois o oposto de fornecer idéias já feitas e matéria já preparada, e de ouvir se o aluno reproduz exatamente o ensinado, não é inércia e sim a participação na atividade. Em tal atividade compartida, o professor é um aluno e o aluno é, sem saber, um professor - e, tudo bem considerado, melhor será que, tanto o que dá como o que recebe a instrução tenha menos consciência possível de seu papel. (Dewey, 1979b, p. 176)

A quinta fase é fundamental para o aprendizado e só ela garante a significação. $\mathrm{O}$ trabalho do problema nas fases anteriores visa à criação de conjecturas, pontos de vista ou métodos para lidar com uma situação, mas ainda não completou o processo: devem ser postos 
em ação para se firmar ou não como solução. Diz Dewey: "Faltam-lhes precisão e certeza enquanto não forem aplicados nessas situações. Somente a aplicação os põe em prova e somente essa comprovação lhe confere pleno significado e o sentido de sua realidade." (Dewey, 1979b, p. 177). Esta fase é de capital importância para que os conhecimentos ainda na forma de conjecturas não sejam elevados à categoria de verdades, num reino mental constituído por si mesmo.

Assim, um primeiro passo é equipar as escolas para desenvolver inteligentemente a experiência diária:

Nos lugares em que as escolas são providas de laboratórios, oficinas e jardins, e em que se usam livremente dramatizações, brinquedos e jogos, existem oportunidades para se reproduzirem as situações da vida, e para adquirir e aplicar informações e idéias na realização de experiências progressivas. As idéias não ficam segregadas, a formarem uma ilha isolada. Elas animam e enriquecem o curso da vida comum. Os conhecimentos vitalizam-se com o ser postos em ação, com o exercerem a sua função na direção das atividades. (Dewey, 1979b, p. 178)

Dewey defende que as escolas sejam aparelhadas com recursos que criem o ambiente para a aprendizagem, "de modo a proporcionar aos estudantes ensejo para adquirirem e provarem as idéias e os conhecimentos em trabalhos ativos reproduzindo (typifying) importantes situações sociais.” (Dewey, 1979b, p. 179)

Mesmo numa escola não adequadamente equipada, os professores podem utilizar métodos mais adequados de interconexão da experiência extra-escolar com a matéria escolar, fazendo com que o estudante estabeleça os respectivos contatos e influências mútuas:

Mas este estado de coisas não serve de desculpa aos professores para cruzarem os braços e persistirem em métodos que afastam, isolam e tornam inúteis os conhecimentos escolares. Cada lição de dada matéria fornece ocasião de estabelecer associações estreitas entre o assunto tratado e as mais amplas e diretas experiências da vida quotidiana. (Dewey, 1979b, p.179)

\subsection{Educar e agir com método}

A educação escolar tem como uma das suas preocupações diárias a administração das matérias do estudo e dos métodos. Neste âmbito, tem reinado o dualismo entre método e matéria, decorrente do dualismo entre mente e mundo, espírito e matéria. Esta separação significa que a matéria consiste na "completa classificação sistematizada dos fatos e princípios sobre o mundo material e sobre o homem" e o método como "a consideração dos 
meios com os quais o espírito possa ser externamente levado a entrar em contato com essa matéria, de modo a facilitar sua aquisição e sua posse." (Dewey, 1979b, p. 181) Pressupõe-se que esta separação constitui algo real e não uma distinção mental.

Matéria e método constituem uma unidade, uma mútua conexão, para Dewey: "Método significa esse arranjo da matéria para tornar eficaz sua utilização. Nunca é o método alguma coisa exterior ao objeto, à matéria.” (Dewey, 1979b, p. 182) Eficaz porque reduz a perda de tempo e energia ao mínimo no processo de se utilizar do material para resultados desejados. Sendo o método o modo de proceder ao tratar determinada matéria, ele não existe sem um material determinado; ele não é antítese da matéria a ser estudada, mas de uma ação casual, mal considerada, do espontaneísmo. Método significa a adequada ou adaptada relação entre os meios e fins: "método é unicamente um meio eficaz de empregar algum material com algum determinado fim.” (Dewey, 1979b, p. 183)

A separação entre método e o objeto desaparece no processo da experiência, ou seja, é uma atividade organizada e interativa entre a pessoa e o material, ou entre a ação do indivíduo e do meio. Daí a noção de experiência: "A experiência, em suma, não é uma combinação do espírito com o mundo, do sujeito com o objeto, do método com a matéria, e sim uma única interação contínua de grande diversidade de energias (literalmente inumeráveis)." (Dewey, 1979b, p.184)

Entretanto, a reflexão sobre uma experiência, ou a experiência da experiência, ao invés de estar imerso em seu curso, permite distinguir a atitude, o ato de experimentar, ou o como os objetos ou coisas são experimentadas. Discriminam-se mentalmente os aspectos do "como" e de "o que" da experiência, e se analisa a relação entre eles. É assim que a análise científica procede. Por exemplo, pode-se distinguir no ato de comer os dois aspectos: comer e alimento e analisar cada um em separado. A análise destaca certos elementos entre estas partes - o como e o que - tornando-os mais perceptíveis e, portanto, mais reguláveis ou controláveis. Observadas as relações causais e dispostas em ordem dispõe-se de um método para agir, ou de uma técnica. Diz Dewey: “Adquirindo-se uma idéia do como a experiência procede, passamos a saber que fatores devem ser assegurados ou modificados com o fim de ter ela melhor êxito." (Dewey, 1979b, p. 184-185)

Os males do dualismo método e matéria para a educação podem ser assim enumerados: 
O primeiro é o esquecimento das "situações concretas da vida prática" (cf., Dewey, 1979b, p. 185). Com isso, as crianças ficam impedidas de ter experiências diretas através das quais os professores poderiam inferir os métodos que utilizam e cooperar com o desenvolvimento. Empobrece, assim, a experiência e o desenvolvimento da peculiaridade pessoal em relação ao método. Os professores têm que seguir métodos autoritários e uniformes, ao invés de desenvolver suas próprias observações.

O segundo dualismo assenta sobre as falsas noções de disciplina e interesse. A idéia de um método pronto e aplicável eficazmente a todo material recorre a meios para estabelecer a relação que falta neste pressuposto: o apelo ao prazer, à excitação, ao tornar palatável; ou no oposto desta situação, que é despertar o interesse através da ameaça com consequiências desagradáveis; ou ainda o apelo direto ao esforço sem justificativas. Em todos os casos subjaz o apelo ao medo de resultados desagradáveis.

A terceira forma danosa do dualismo é "fazer-se do ato de aprender um fim direto e consciente por si mesmo" (Dewey, 1979b, p. 186), pervertendo a lógica natural do aprender como um resultado significativo - produto ou recompensa - de suas atividades diretas com a matéria. O aluno desenvolve a atitude de "ter de aprender", e não o aprender tendo em vista razões e fins reais, ou seja, o valor da matéria no curso de suas atividades.

Em quarto lugar, o mal que o método fixo acarreta é a rotina árida, "a seqüência mecânica de determinados passos prescritos.” (Dewey, 1979b, p. 187) A própria teoria pedagógica cai no descrédito na medida em que, admitindo este dualismo, concebe sua função como sendo a de fornecer receitas e modelos prontos para os professores seguirem. Contrapõe Dewey: "A maleabilidade e a iniciativa na solução dos problemas são característicos de qualquer concepção em que o método seja o modo de tratar-se um material para atingir-se uma conclusão." (Dewey, 1979b, p. 187)

Há no campo da educação o que se poderia chamar de métodos gerais. Eles se referem ao conjunto de experiência alheias eficazes para a aquisição de conhecimentos. Conhecer o cabedal de métodos acumulados historicamente e autorizados pela experiência passada e análise intelectual consiste, em parte, do processo de aprendizagem, tanto do professor como do aluno. Eles constituem uma base sobre a qual a iniciativa e originalidade individual podem crescer com mais vigor e consistência, desde que usados inteligentemente na devida adaptação aos casos concretos. Isto implica em romper tanto com a atitude de aplicação uniforme de métodos fixos, que pressupõem a noção errônea, fictícia, de que espírito ou mente e processo intelectual são os mesmos para todos os indivíduos, que diferem 
apenas em quantidade. (cf. Dewey, 1979b, p. 190) A originalidade tem que ser vista mais como um critério democrático, do que uma excepcionalidade ou privilégio. No excerto a seguir Dewey explicita a defesa desta idéia:

Não é da alçada do professor comparar a quantidade de aptidões de um aluno com a de outro. Isto não tem importância para a sua tarefa. O que se requer é que cada indivíduo tenha oportunidades para empregar suas próprias capacidades em espécies de atividade dotada de significação. Espírito, método individual, originalidade (são termos reversíveis) significam a qualidade da ação intencional, ou orientada para um fim. Se, como mestres, procedermos nesta convicção, asseguraremos a manifestação de mais originalidade, mesmo segundo o padrão convencional de originalidade, do que a obtida atualmente. Impor a todos um pretenso método uniforme geral é produzir a mediocridade em todos os alunos, exceto nos verdadeiramente excepcionais. E medir-se a originalidade pela sua diferença do comum dos alunos é impelir à excentricidade esses excepcionais. Desta maneira atrofiamos as qualidades distintas da maioria e, salvo em raros exemplos (como no caso de Darwin), eivamos os raros gênios com uma qualidade malsã. (Dewey, 1979b, p.190)

Desta análise da relação entre método e matéria, em termos mais gerais, Dewey infere a necessidade de estudar as características específicas, ou o "modo individual" de lidar com um problema. Este modo individual é caracterizado pelas tendências inatas, hábitos e interesses adquiridos, variando de uma pessoa para outra, que determinam o método: "os métodos continuam a ser o interesse, o contacto e o modo de trabalhar pessoais de um indivíduo em relação à matéria do estudo e jamais se poderão catalogar todas as suas formas e matizes." (Dewey, 1979b, p.191)

Por isso, o professor deve estudar a criança, a psicologia e o meio social que somados aos demais conhecimentos auxiliarão a compreender as reações dos alunos e guiá-las tendo em vista maior eficiência.

As atitudes que Dewey coloca como essenciais para um procedimento intelectual eficiente sobre o material são as seguintes:

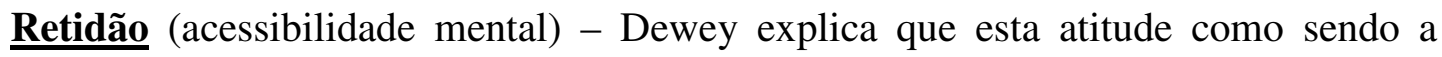
relação íntima entre a pessoa e a atividade que desenvolve. Em outras palavras, esta atitude significa confiança: "Denota antes a retilineidade com que a pessoa se aplica ao que acha a fazer. (...) Significa elevar-se ao nível das necessidades da situação.” (Dewey, 1979b, p. 192 174). Este interesse imediato e direto pela matéria da atividade contrasta com atitudes como inibição, embaraço e constrangimento. Estas atitudes revelam que a pessoa está dividida entre pensar no problema e pensar em si mesma. Algumas vezes, Dewey chama a atenção para a atitude de autoconsciência (self-conscious ou self-consciousness) como fazendo parte do 
grupo de atitudes que inibem o processo de aprender ou estudar. É preciso ter bem claro que, algumas vezes, esta atitude representa uma tomada de consciência para corrigir um falso modo de lidar com a matéria, visando melhorar a eficácia, e, portanto, salutar ao processo. Outras vezes, significa a fixação nas próprias atitudes, desviando sua energia do foco do problema ou matéria. A persistência nesta atitude pode criar a tendência do descuido e de busca de motivação fora do objeto de estudo, inclusive na dependência de sugestões e orientações externas.

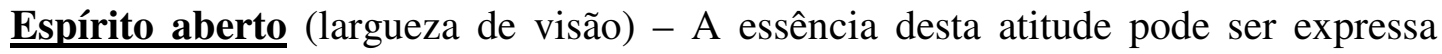
como sendo a curiosidade vigilante, a procura pelas novas concepções, acolhimento de sugestões e informação pertinentes ao material de estudo, considerando o lugar de cada contribuição. Diz Dewey: “Acessibilidade mental significa estar o espírito franqueado a toda e qualquer consideração que projete luz sobre a situação, que precisa ser aclarada e que ajude a determinar as conseqüências deste ou daquele modo de proceder. (Dewey, 1979b, p.193)

Esta atitude de hospitalidade ativa permite reconhecer erros nas crenças e alargar horizontes para pontos de vistas até então estranhos ou alternativos, que quando considerados devidamente modificam as concepções atuais e abrem a percepção de novos problemas e possíveis soluções.

As atitudes inimigas de um espírito aberto que impedem o desenvolvimento são as seguintes: preconceitos, partidarismos, teimosia, hábitos como o de cerrar a mente e indispôla à consideração de alternativas, indolência mental, presunção, medos inconscientes.

Uma educação que contrasta com esta atitude é a que se apega à uniformidade rígida dos métodos e processos que prometem rapidez, perfeição, e a mensuração de resultados imediatos. $\mathrm{O}$ aluno restringe sua visão àquela do professor, que não permite nem encoraja a busca de modos diversos de resolver as questões. Dewey critica esta postura pelos limites que impõe ao desenvolvimento educativo: "Se todos os docentes compreendessem que pela qualidade dos processos mentais, e não pela obtenção de respostas certas, é que se mede o desenvolvimento educativo, dar-se-ia quase que uma revolução nos processos do ensino". (Dewey, 1979b, p.194)

Espírito concentrado (Integridade de propósitos e objetivos - atividade integrada) Dewey define da seguinte forma o teor desta atitude: "é a plenitude do interesse, a unidade de objetivo; [...] significa a integridade mental. Absorção, concentração, paixão pela matéria e o 
pleno interesse nela, pelo seu próprio mérito a alimentam e fortalece.” (Dewey, 1979b, p. 194) Suas qualidades são a inteireza mental, honestidade e sinceridade.

Os inimigos desta atitude - que impedem que a atividade mental se torne integral e completa é: a duplicidade de objetivos, um manifesto que serve de máscara e outro recalcado, mas operante; atenção dividida pela duplicidade de desejos: os desejos latentes que determinam o curso da reflexão e das reações emocionais, e os desejos de atender ás expectativas dos outros (agrado, aprovação, respeito à autoridade, medo de punições, senso de dever, etc.); o duplo julgamento da realidade, um conforme o interesse particular e outro para uso público. A atividade reflexiva resulta constrangida, frouxa, furtiva e até desmoralizado em casos extremados. A expressão que melhor cabe nesse caso é "servir a dois senhores ao mesmo tempo."

Esta atitude é adquirida pelo estímulo consciente. Por isso, a educação poderá tomar dois caminhos: um é o de provocar a divisão do espírito entre o confessado e o íntimo, conforme exposto anteriormente. Corroboram para esta divisão, práticas como a disciplina severa e exercícios mecânicos, que conseguem alguns resultados, mas os desejos e paixões encontram outras válvulas de escape. Complementando o raciocínio: "O aluno presta uma atenção externa, perfunctória, ao professor, ao livro, à lição, enquanto os pensamentos íntimos se lhe concentram em assunto de imediato interesse." (Dewey, 1979a, p. 40) O estudo adquire o caráter de obrigação: agradar o professor ou pais ou responder perguntas como mero dever escolar, passar em exames, obter notas.

O outro direcionamento do estímulo escolar consiste na produção da adequada atitude mental. A atividade mental integrada, comenta Dewey, é expressa da seguinte forma: "Perguntas espontaneamente lhe ocorrem; uma torrente de sugestões o inunda; depara e segue outras pesquisas e leituras." (Dewey, 1979a, p. 40) Revela que a matéria prendeu o espírito do aluno despertou um entusiasmo genuíno que lhe dá força intelectual para lidar com o problema. Esta é uma das tarefas do professor: "O professor que desperta tal entusiasmo em seus alunos conseguiu algo que nenhuma soma de métodos sistematizados, por corretos que sejam, poderá obter.” (Dewey, 1979a, p. 40)

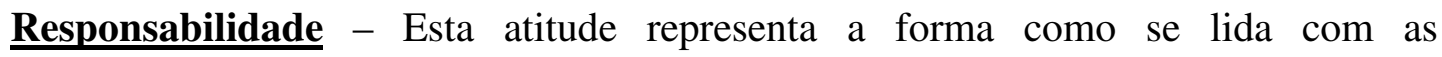
conseqüências no processo de reflexão, ou seja, com o processo de prever e pesar conseqüências prováveis e aceitá-las deliberadamente, contando com elas na ação. Diz Dewey: "Ser intelectualmente responsável é examinar as conseqüências de um passo projetado; significa estar disposto a adotá-las, quando seguem, como de razão, qualquer 
posição já tomada. A responsabilidade intelectual assegura a integridade, isto é, a consistência e a harmonia da crença. (Dewey, 1979a, p. 41)

A prática escolar inimiga desta atitude intelectual da responsabilidade é a que procede por imposição de assuntos ou fatos estranhos à experiência do aluno, ou despejados em excesso e de maneira desconexa. As crenças assim apresentadas pelo professor ou pelo compêndio tornam-se muito distantes das crenças que funcionam na vida do aluno fora da escola. Cria o senso de "dois pesos e duas medidas" em relação à realidade. Pode gerar uma profundeza mais material através de exercícios mecânicos e exaustivos sobre as particularidades da matéria. Assim, tendência é formar a atitude intelectualmente irresponsável ou uma mente confusa incapaz de pesar ou perguntar sobre a significação do que aprende para as crenças e ações. O professor pode preservar essa atitude, conforme sugere Dewey: "Menos matéria, menos fatos e mais responsabilidade em pensar detidamente no material de tais matérias e fatos, a fim de compreender o que está neles abrangido, daria melhores resultados." (Dewey, 1979a, p. 41) A profundeza intelectual salutar é aquela que confere capacidade de "ver completamente alguma coisa" (cf. Dewey, 1979b, p. 197), desenvolvendo a significação de um propósito que congrega detalhes e direciona a própria ação, evitando perder-se nos detalhes ou submeter-se a orientações externas da ação.

\subsubsection{A natureza da matéria de estudos}

Dewey coloca, no livro "Vida e Educação", dois elementos fundamentais do processo educativo, que são a criança como um ser imaturo e certos fins, idéias e valores sociais da experiência amadurecida do adulto. A teoria da educação tem dado diferentes tratamentos a estes fatores, oscilando entre visões que isolam um do outro ou enfatizam um em detrimento do outro, ou os tratam de forma antagônica. O tratamento que Dewey se propõe dar a esse problema é o de compreendê-los dentro de uma realidade mais profunda de totalidade do processo. Dewey sintetiza os pontos principais do conflito entre a criança e o currículo:

[...] primeiro, o mundo pequeno e pessoal da criança contra o mundo impessoal da escola, infinitamente extenso, no espaço e no tempo; segundo, a unidade de vida da criança, toda afeição, contra as especializações e divisões do programa; terceiro, a classificação lógica de acordo com um princípio abstrato, contra os laços práticos e emocionais da vida infantil. (Dewey, 1959b, p. 53-54)

Diante destes conflitos, uma tendência pedagógica elege como fim da educação os conceitos da experiência amadurecida do adulto, como matéria do programa, e a criança como 
aquele ser que recebe e acumula passivamente as matérias. O professor dirige e controla o processo, e para isso serve-se da disciplina. O que é substantivo para esta tendência é o passado, a lei, a ordem, a direção autoritária. Outra tendência educacional deposita na criança o centro e o fim da educação. Seu foco é o desenvolvimento das capacidades, da individualidade. É o processo ativo e interno de crescimento que serve de medida e julgamento para a educação. O método é a completa liberdade e o espírito evolui e progride na medida em que naturalmente se ocupa com os conceitos. O professor deve conhecer a criança e agir de forma simpática, para que ela faça seu percurso de novidades, descobertas, progressos. Dewey critica estas tendências por dois motivos: por um lado, adotam a noção de matérias como coisas fixas, integrais e alheias à criança; por outro, ou depreciam moral e intelectualmente a criança, ou idealizam sentimentalmente sua natureza; em ambos os casos projetam estágios de crescimento fixos e completos.

Qual é o papel do professor, da criança e da matéria para Dewey?

Dewey compreende as relações entre a criança e a experiência do adulto como um processo de interação e ajustamento. Falar de experiência da criança é reconhecer que ela já contém "elementos da mesma natureza daqueles que compõem a matéria de estudos e (...) implica as atitudes, motivos e interesses que levaram à organização da disciplina de estudos ao nível que hoje ocupa." (Dewey, 1959b, p. 53-54) A experiência da criança tem aspecto psicológico. Descrever a experiência no sentido psiclógico é compreender a experiência em sua história de desenvolvimento. E as matérias são experiências amadurecidas, organizadas e sistematizadas em fórmulas e símbolos que têm aspecto lógico, isto é, despreza-se o seu processo. Diz Dewey: "Da experiência passada essa organização lógica retira tudo que é significativo e útil para o governo da experiência futura. As abstrações, generalizações e classificações têm todas essa significação e valor de direção do futuro." (Dewey, 1959b, p. 70) Assim, para Dewey, a experiência da criança e a experiência sistematizada do adulto constituem uma mesma realidade, sendo que uma representa um processo em fase mais inicial e outra em fase mais adiantada.

Qual a importância para a educação de colocar o problema desta forma? Dewey explicita o critério de orientação: "A experiência sistematizada e lógica do adulto serve-nos para interpretar, guiar e dirigir a vida infantil, tal qual se processa no momento." (Dewey, 1959b, p. 59) Conhecer o desenvolvimento da experiência do adulto expresso na matéria é fundamental para selecionar os materiais da aprendizagem e circunscrevê-la de acordo com os impulsos e interesses vitais da criança. Diz Dewey: 
[...] a não ser que o mestre conheça, e conheça perfeita e acabadamente as experiências da humanidade que estão consubstanciadas naquilo a que chamamos de programa, ele não saberá nem quais são as capacidades, habilidades e atitudes da criança, nem como pô-las em função e atividade para sua realização. (Dewey, 1959b, p. 81)

$\mathrm{Na}$ experiência da criança sobressaem forças e interesses que profetizam seu futuro. As significações que se formam não podem ser compreendidas como algo definitivo, mas impulsos para continuar o crescimento e atingir um nível mais alto. E o programa escolar, com direção à observação e raciocínio, pode nos ajudar a compreender melhor a criança e seus interesses e tendências, para dirigir e guiar a atividade educativa. Assim, interpretação e direção têm, para Dewey, o seguinte sentido:

Interpretar é ver o fato em seu movimento vital, é vê-lo em relação ao crescimento infantil. E vê-lo desse modo, como uma parte do crescimento normal, é ter um critério para dirigir. Direção não é imposição externa: é a libertação do processo vital para o seu curso mais completo e mais adequado desenvolvimento. (Dewey, 1959b, p. 64-65)

A educação tradicional compreendia desenvolvimento a partir de uma direção e controles arbitrários, que oferecem o caminhos e compelem a criança para o seguimento. A educação nova via o desenvolvimento de forma vazia e formal, pressupondo que o espírito é capaz de extrair de sua própria natureza as verdades. Para Dewey, o desenvolvimento depende da interação entre a criança e a experiência do adulto através da experiência: "O verdadeiro desenvolvimento é um desenvolvimento da experiência e pela experiência." (Dewey, 1959b, p. 66, itálicos do autor) A experiência ocorre sempre em um meio, numa situação, e relacionada a certas condições e nunca no vácuo. Para operar, a experiência requer por parte de um indivíduo certas tendências, hábitos, e forças e também de materiais, objetos e condições. A experiência da aprendizagem depende da organização do meio com estímulos e materiais adequados, para que os interesses e forças da criança entrem em operação. A educação para Dewey se dá pela reação da criança a um meio. A inteligência reage ao que é apresentado neste meio. Seguindo este princípio a função do professor é organizar este meio:

O papel do educador na empresa da educação é proporcionar o ambiente que provoque reações ou "respostas" e dirija o curso do educando. Em última análise, tudo o que o educador pode fazer é modificar os estímulos ou situações, de modo que das reações resulte o mais seguramente possível a formação de desejáveis atitudes intelectuais e sentimentais. (Dewey, 1979b, p.199)

E com que elementos o professor organiza o ambiente? São duas as fontes de recursos para criar o ambiente: "É óbvio que os estudos ou as matérias do programa têm muito que ver 
com a função de fornecer um ambiente. O outro ponto é a necessidade de um meio social para dar significação aos hábitos formados.” (Dewey, 1979b, p.199)

Isto quer dizer que o professor atua no sentido de traduzir em termos psicológicos a matéria que se encontra em ordem lógica. Por isso, estas instâncias não são concebidas de forma antagônica, uma em relação à outra.

Dewey considera a matéria de estudos como a matriz do intercâmbio social numa educação informal ou assistemática. Tem-se, neste fato, uma chave para tratar a matéria formal e sistemática. Diz Dewey: "o principal fim de nossa exposição teórica é patentear a conexão que com tanta facilidade perdemos de vista, e mostrar com alguma minudência o conteúdo e a função social dos principais elementos componentes do curso de estudo ou currículo.” (Dewey, 1979b, p. 200-201)

Dewey analisa essa questão sob o ponto de vista do especialista (cientista) professor e do aluno. O cientista toma os conceitos de seu campo de conhecimento, como material para descobrir novos problemas, fazer novas pesquisas e chegar a novas conclusões. Neste caso, os conceitos são relacionados uns com os outros, o que permite lidar com novos fatos. Desta forma os conceitos têm um fim em si mesmos.

O significado da matéria de estudos para o professor é que ela representa uma certa fase de desenvolvimento e fornece os padrões definidos, que revelam possibilidades das ações dos alunos que ainda se encontram em estado bruto ou incipiente. As matérias traduzem os significados da presente vida social ou os "elementos essenciais da cultura a ser perpetuada" (Dewey, 1979b, p. 201) A organização da matéria de estudos em significações estandardizadas previne o professor de empregar esforços ao acaso. E, mais importante ainda, estes recursos oferecem um excelente capital para o professor compreender e orientar "o significado das reações aparentemente impulsivas e sem objetivo dos jovens e de fornecer os estímulos necessários para orientá-las, de modo que resultem em alguma coisa útil." (Dewey, 1979b, p. 201)

Há um distanciamento entre o professor e o aluno. O professor pode utilizar eficazmente em sua atividade os recursos das diversas disciplinas (matérias), formuladas, cristalizada e sistematizadas. Seus conhecimentos são mais amplos, baseados em princípios que extrapolam os limites da experiência da criança. $\mathrm{O}$ aluno está na fase de aprender. $\mathrm{O}$ método de organizar a matéria na cultura segue critérios lógicos, diferentes dos que vão 
iniciar-se. A criança organiza as experiências de acordo com centros de interesse diretos e práticos. Dewey explicita esta diferença e os problemas de cada um da seguinte forma:

Quando empenhado no ato direto de ensinar, o professor deve estar familiarizadíssimo com a matéria, mas a sua atenção deve concentrar-se na atitude mental e nas reações do discípulo. Sua tarefa é compreender este último em sua relação com a matéria, ao passo que a atenção do aluno não estará naturalmente em si próprio, mas no tópico a estudar. (Dewey, 1979b, p.202)

Dewey concebe três estágios para o aprendizado da matéria sob o ponto de vista do educando. O primeiro consiste em um saber fazer as coisas; "o saber é uma habilidade inteligente", ou "um poder fazer" (Dewey, 1979b, p. 204_184), diz Dewey. Alguns exemplos são: andar, falar, ler, escrever, contar, andar de bicicleta, vender/comprar objetos, tratar as pessoas e a infinidade de coisas. No curso natural do desenvolvimento a criança aprende através de suas atividades, ou como Dewey coloca, estas situações envolvem o "aprender fazendo" (Dewey, 1979b, p. 204_184) Assim, o saber da criança consiste no manuseio e familiaridade com as coisas. O princípio do aprender a fazer as coisas de modo direto equivale a pensar a educação através de atividades simples e sociais em que os alunos possam manifestar suas aptidões sem compulsão externa (de dor ou prazer). Conhecimentos e aptidões adquiridas dos materiais, instrumentos e do próprio esforço empregado, têm sua continuidade ativa em situações extra-escolares. $O$ segundo estágio consiste no aprofundamento e ampliação dos conhecimentos, através da atividade compartilhada, ou da comunicação com as outras pessoas. O acervo de conhecimentos sociais se avoluma através da intercomunicação e da interpenetração da experiência da criança com seus pares. Assim, conhecimentos remotos no espaço e no tempo, na medida em que nos interessam, passam a afetar o resultado de nossas ações e a integrar a experiência. Para Dewey, a comunicação em nível pessoal oferece um critério para avaliar o valor pedagógico do material informativo: a relação da informação com o interesse do aluno e o ajustamento a seu material familiar tornando-o mais eficaz e profunda sua significação. Sobre este material, diz Dewey: "O cabedal de coisas ouvidas ou lidas tem importância - e, quanto maior for, melhor - mas somente se o educando dele necessitar e o puder aplicar em alguma situação dele, educando”. (Dewey, 1979b, p.206) Aqui Dewey desfere crítica à maneira como o saber mudou seu significado, para expressar o volume de conhecimentos acumulados e registrados, independente da sua função como resultantes da investigação e recursos para investigações futuras. Diz Dewey: "O espírito do homem é aprisionado pelos despojos de suas vitórias anteriores; e, para determinar a significação de saber, de fato e de verdade, ele costuma 
referir-se a esses despojos e, não às armas da conquista e ao ato de abalançar-se a combater contra desconhecido. (Dewey, 1979b, p. 206-207)

Para Dewey, a informação tem valor educacional na medida em que se faz necessária no trabalho com um problema: oferece sentido e orientação à pesquisa e contribui na solução do mesmo. Aproveitando das palavras de Dewey:

Os conhecimentos informativos são materiais em que nos podemos basear como estabelecidos, certos, seguros, em uma situação duvidosa. São uma espécie de ponte para o espírito, em sua passagem da dúvida para a descoberta. Seu papel é o de intermediários intelectuais. Eles condensam e registram em forma utilizável os resultados apurados da experiência anterior da humanidade, como meio de interpretar e iluminar o sentido de novas experiências. (Dewey, 1979b, p.208_ 188)

A ciência como resultado final do aprendizado do homem é, para Dewey, aquele saber certo, seguro, assentado "com que pensamos" mais do que "sobre o que pensamos". (cf. Dewey, 1979b, p. 208 -188)

\subsubsection{A matéria de estudo em sua natureza social}

Diante do grande lastro de conhecimentos é importante que a educação adote o critério do valor social para a seleção dos materiais conforme cada fase. Assim, a preparação das pessoas para serem membros da sociedade atual requer um plano de currículo, onde os estudos estejam adaptados para as necessidades da vida atual, visando melhorar a vida em comum. No primeiro plano deste currículo, devem estar as coisas essenciais, diz Dewey, explicando-se: "essenciais são as socialmente mais fundamentais, isto é, as relacionadas com a atividade compartilhada pelos grupos mais amplos.” (Dewey, 1979b, p. 211_191) Secundário é o que se refere aos grupos especializados e técnicos. A educação humana não é aquela restrita a uma classe especializada de instruídos que conserva as tradições clássicas do passado, mas aquela em que "a matéria se humaniza na proporção em que se relaciona com os interesses comuns dos homens, em sua qualidade de homens." (Dewey, 1979b, p. 212_191)

A sociedade democrática depende de se considerar o critério social, no costume de organizar o plano de currículo de cunho largamente humano. O fracasso da democracia está ligado aos critérios que orientam a educação:

A democracia não pode florescer quando os principais critérios para a escolha das matérias educativas são os fins utilitários estreitamente concebidos para as massas, e, quando se escolhem para a instrução mais 
elevada dos outros poucos, as tradições de uma classe instruída especializada. (Dewey, 1979b, p. 212)

A crítica deweyana dirige-se à noção corrente de que os elementos essenciais da educação são as habilidades de ler, escrever e contar, ignorando as demais coisas essenciais para os ideais democráticos. A eficiência maquinal no ler, escrever e contar, somada a certa destreza muscular, priva as pessoas da liberdade de escolha e as coloca sob a orientação de fins alheios e direção de outras pessoas, com vistas a uma recompensa pecuniária (cf. Dewey, 1979b, p 212) O resultado é uma cultura parasitária, explica Dewey:

Elas implicam uma cultura um tanto parasitária, adquirida à custa de ficar-se privado da clarividência e disciplina que derivam do interesse pelos mais importantes problemas comuns da humanidade. Um programa de estudos que tenha em vista as responsabilidades sociais da educação, deve apresentar situações cujos problemas sejam relevantes para a vida em sociedade e em que se utilizem as observações e conhecimentos para desenvolver a compreensividade e o interesse sociais. (Dewey, 1979b, p. 212_192)

\subsection{Educar e o respeito à vida da criança: corpo, imitação, brinquedo e trabalho}

Já analisamos o conceito de imaturidade. Discutimos em muitos aspectos o processo de formação do conceito. Retomaremos, agora, a versão deweyana da construção de conceitos, do ponto de vista do desenvolvimento do ser humano.

Dewey coloca que o estágio inicial do primeiro ano e meio de vida consiste na atividade do bebê, que tem como primeiro problema dominar e usar o próprio corpo. Embora uma criança nasça com quantidade maior de reações instintivas que os outros animais, elas são menos perfeitas e só podem ser usadas após longo período de aprendizado. Assim, a criança vai aos poucos transformando seu corpo num instrumento de adaptação confortável e eficaz às condições físicas e sociais. Para chegar ao êxito de suas atividades de controle físico - ver, ouvir, pegar, movimentar o corpo, engatinhar, andar, ligar sons, impressões gustativas e táteis a imagens, etc. - a criança executa várias operações como a observação, escolha, coordenação consciente em vistas de um fim. Estas operações e a aquisição resultante constituem uma aquisição intelectual, e não meramente física, como se costuma dizer, pois constituem processos do pensar, ainda que de natureza rudimentar. A atividade física que tem que ser aprendida tem necessariamente qualidade intelectual ou mental. Qualquer desenvolvimento ulterior depende deste aprendizado em torno do domínio do corpo. É esta fase do primeiro ano e meio de vida do bebê marcada por um intenso e alegre 
desenvolvimento na capacidade de controlar os movimentos. Isto é demonstração do genuíno interesse, que traz como resultado o aumento de significados da ação.

Conexo com o domínio físico do corpo, a criança desenvolve o ajustamento social com as pessoas de seu relacionamento imediato: mãe, pai, irmãos, babá, etc. As relações da criança com o meio físico são reguladas por essas pessoas e a criança aprende os sinais que indicam a solução de certos problemas como a fome, frio, desconforto, dores, atenção, etc.

Chegamos assim ao ponto mais significativo do ajustamento social que se dá com o domínio da linguagem conforme fala Dewey:

[...] é a linguagem a adaptação precisa dos movimentos da língua e dos lábios aos sons ouvidos, que se torna o grande instrumento de ajustamento social: conexa com o desenvolvimento da linguagem (ordinariamente no segundo ano), a adaptação das atividades das crianças às das outras pessoas e em conjunto com as outras pessoas apresenta a característica fundamental da vida social. (Dewey, 1979a, p. 205)

Assim, o meio natural da criança é povoado pelo conjunto de invenções e planos das gerações passadas, que estão presentes nas atividades dos adultos. Estas acrescentam aos estímulos naturais estímulos novos e diretos, mais ricos, organizados, complexos e ajustados às necessidades, de forma que a criança concentra a atenção numa ordem de problemas e materiais mais elevados. Acrescenta Dewey: “Aprendendo a entender e dizer palavras, as crianças aprendem muito mais do que palavras: adquirem o hábito que lhes descerra um novo mundo." (Dewey, 1979a, p. 205)

\subsubsection{A imitação}

Dewey discute a natureza e o papel da imitação na formação das disposições mentais, no contexto do desenvolvimento infantil. Aponta o equívoco de educadores e psicólogos, que entendem que os atos que se parecem ou reproduzem o procedimento dos adultos tomados como modelos ocorrem por instinto imitativo, como algo inconsciente. Se assim fosse a imitação seria dos fins, superficial e transitória, não produzindo efeito na formação mental, porque desprovida do significado. Isto descaracteriza a imitação, pois inverte a ordem das coisas tomando efeitos por causas. Não poderia ser um agente de direção e controle social a menos que se queira a compulsão e formação de hábitos externos.

A pergunta que tem que ser colocada para se compreender a imitação é: por que a criança procede deste modo? Dewey coloca que a imitação tem que ser entendida a partir do 
processo de associação, especialmente a instrução em que ocorre a aprovação ou reprovação dos atos. Grande influência tem a pressão social, através da qual se admite quem procede de acordo com modo usado pelo grupo e exclui quem procede de modo diferente. Dewey defende o papel ativo do hábito: "O que se chama efeito da imitação é precipuamente o resultado da instrução consciente e do influxo selecionador exercido pelas confirmações e ratificações inconscientes, dos atos de alguém, por parte daqueles com quem se associou." (Dewey, 1979b, p. 37)

Outro componente importante é considerar a situação como um todo em que a criança adapta seus atos, considerando o que o outro fez ou vai fazer. Imitação tem apenas um papel subalterno. Há que se considerar que a criança é ativa, tem interesses próprios, que a leva a reagir em função de um fim desejado. Sua imitação se concentra nos meios de fazer algo tendo em vista um fim. Por exemplo, no caso de jogar bola ela observa os procedimentos dos outros, com a finalidade de aperfeiçoar os seus e conseguir interagir de forma a atingir uma meta que é jogar bem. A atividade do adulto oferece à criança estímulos interessantes, variados, complexos e novos promovendo o rápido progresso do pensamento. A atividade associada exige adaptar, interagir e não pode ser mera reprodução imitativa, sem a função inteligente do pensamento. A significação é a mesma, entretanto, os modos de manifestação e execução são diferentes. Diz Dewey:

As palavras, os gestos, os atos, as ocupações de outra pessoa se coadunam com um impulso já ativo e sugerem algum modo de expressão adequado, algum fim, em que esse impulso encontrará satisfação. (...) O observador poderá notar que esse ato se parece ao do adulto e disso conclui que foi adquirido por imitação, quando, de fato, o foi pela observação, seleção, experimentação, e confirmação por meio dos resultados. (Dewey, 1979a, p. 206 , itálicos do autor)

Este instinto imitativo pode ser utilizado para se desenvolver ações eficientes de direção e controle social pela educação, desde que seja compreendida a partir do processo de associação, em que há uma resposta inteligente aos estímulos do meio social.

A discussão sobre a imitação não pode ser separada do interesse mútuo das pessoas em proceder correspondendo aos atos das outras pessoas e que desta forma se promove a direção e controle social. Acentua Dewey a influência das atividades dos adultos sobre as crianças:

A presença das atividades dos adultos desempenha grande papel no desenvolvimento intelectual da criança, porque acrescenta aos estímulos naturais do meio, outros estímulos, tanto mais exatamente ajustados às necessidades de um ser humano, quanto são mais ricos, melhor organizados, mais complexos, permitindo adaptações mais maleáveis e produzindo novas reações. (Dewey, 1979a, p. 207) 
O estímulo do ambiente social exerce papel importante para se compreender a perpetuação da sociedade. A diferença de cultura, como por exemplo, de um grupo selvagem e um civilizado, não está no menor ou maior grau de capacidades inatas inteligentes, mas nos estímulos que o ambiente social oferece. Vejamos o excerto de Dewey:

O progresso da civilização significa que maior número de forças e coisas naturais foi transformado em instrumento de ação, em meios para se atingirem fins. Não é tanto pelo começarmos com capacidades superiores, mas, sim, devido aos estímulos superiores para provocar e dirigir a manifestação de nossas capacidades, que somos civilizados." (Dewey, 1979b, p. 39)

Assim, a atividade associada gerando o progresso das tecnologias oferece estímulos variados e apurados para provocar e dirigir as capacidades dos membros de um grupo. Em breve tempo uma criança consegue se apropriar de recursos, que levaram séculos para se desenvolver. O estado de selvageria representa a falta de domínio das forças naturais, ou seja, um escasso número de coisas figura em suas atividades conjuntas. Os estímulos advindos das atividades sociais destes grupos são brutos, fixados em qualidades de atenção imediata e de interesse, que não permitem frutificar o espírito. As instituições atrasadas destes grupos limitam os estímulos e atividades de seus membros: "São de tal sorte suas atividades sociais, que lhes restringem os objetos da atenção e interesse e, por isso, limitam-lhe os estímulos para o desenvolvimento mental." (Dewey, 1979b, p. 39)

\subsubsection{A criança, o brinquedo e o trabalho}

A relação da criança com o brinquedo mostra a reação da criança a um significado evocado pelo objeto, portanto, a presença da inteligência na condução da ação. "No momento em que as coisas ficam sendo sinais, no momento em que adquirem uma capacidade representativa, isto é, a de fazer às vezes de outras coisas, o brinquedo, de mera exuberância física que era, transforma-se em atividade que comporta um fator mental." (Dewey, 1979a. P. 207)

O processo de manipulação do brinquedo é conduzido pelos significados naturais e sociais da criança. Facilmente ela transforma um objeto do mundo físico em algum ideal significado. Neste sentido, existe uma idéia orientadora que dá sentido aos atos sucessivos da criança em vista a resultados. O brincar é uma atividade de experimentação na qual a atitude de fazer ou conseguir algo, "implica previsões de resultados que estimulam as suas reações atuais.” (Dewey, 1979b, p. 224) O resultado previsto é imediato e não implica uma mudança 
especial nas coisas, mas ele alimenta um ato subseqüente fornecendo a continuidade entre eles. Não se trata de prever um resultado exterior remoto. Uma atividade gera a outra, ambas sempre alimentadas por um significado fornecido pela fantasia, e assim, modificam-se fácil e frequentemente os atos. A atividade é seu próprio fim, sendo livre, plástica, variando de natureza, conforme o capricho ou necessidade.

Ao brincar, a imaginação ${ }^{34}$ faz o que quer com os objetos, como vemos, por exemplo, a criança fazer uma pedra se transformar numa mesa, folhas em pratos, vassoura num cavalo, cadeira num carro, etc. As coisas, os objetos físicos representam ou são sinais de outras coisas, e esses significados vão se ampliando infinitamente. Diz Dewey: "Quando a criança brinca de cavalo, de loja, de casinha, ou de comadre, está subordinando o presente físico ao ideal do significado. Define-se e constrói-se, assim, um mundo de significações, uma reserva de conceitos (tão importante para toda operação intelectual). (Dewey, 1979a, p. 207)

Diante destes conceitos ou significações familiares a criança organiza, agrupa, estabelece conexões entre eles e os novos elementos criando uma nova situação como uma história com começo, meio e fim.

O jogo exige domínio de maior quantidade de significados organizados. As regras dão sentido e dirigem os diversos atos sucessivos da criança no uso das coisas num modo definido como meios para um fim e os organizam num todo conexo. (Dewey, 1979a, p. 208)

Dewey destaca que o importante na brincadeira é a vontade de brincar da criança do que o brinquedo em si, porque revela o interesse. Esta atitude do espírito é que conta, pois ela indica a criança agindo com significado, com aquilo que é sugerido das coisas. O brinquedo é só um veículo para a sugestão. Isto faz a atitude de brincar ser livre: "Daí ser a atitude lúdica uma atitude de liberdade. $\mathrm{O}$ ser não se prende às particularidades materiais das coisas e não se preocupa com saber se uma coisa 'significa` realmente o que ela faz representar." (Dewey, 1979a, p. 208, aspas do autor)

A atitude da criança de brincar ou jogar vai aos poucos, à medida que ela cresce, transformando-se em atitude de trabalho. Importa observar a continuidade e cumulatividade de significados que há entre estas atividades, nunca podendo ser coisas contrárias entre si. Para Dewey ambos os tipos atividades "subentendem fins conscientemente demandados, e

\footnotetext{
${ }^{34}$ A brincadeira e o jogo são atividades imaginativas e se contrapõem a atividades rotineiras ou mecânicas: "A participação da imaginação é a única coisa que faz a atividade deixar de ser mecânica.” (Dewey, 1979b, p.259)
} 
seleção e adaptação de materiais e processos destinados a conseguir os fins desejados." (Dewey, 1979b, p. 223). Dewey complementa a semelhança entre as duas atividades, afirmando que o interesse repousa sobre a própria atividade, sendo que no brinquedo o interesse está no decorrer da atividade, de momento a momento, com certa casualidade das circunstâncias - porém sempre com uma idéia orientadora; no trabalho há interesse na atividade em relação ao seu fim ou resultado, existindo um fio de continuidade entre as diversas fases. A diferença é a duração de tempo que as atividades de trabalho requerem, devido à conexão mais complexa entre os meios e fins. As atividades de trabalho exigem a utilização de meios intermediários - aparelhos, instrumentos e habilidades conscientemente aplicados - para tingir fins mais remotos. Há aumento da qualidade mental na medida em que o pensamento precisa regular e sugerir uma seqüência de atos.

A partir de certa idade, as atividades de brincar como ficção, "fazer de conta", passam a ser inadequadas e os estímulos já não produzem significações mentais interessantes na criança. Além disso, o desejo da criança de compartilhar das atividades dos adultos, que implicam modificações exteriores, como preparar uma mesa para refeições, cuidar de animais, fazer os próprios brinquedos. $O$ interesse passa a se concentrar em atividades, cujas significações requerem resultados mais concretos, visíveis e tangíveis, de transformação real de certas condições externas. Dewey refere-se a trabalho no sentido psicológico, ou seja, uma atitude mental, e não simples atividade exterior, que tem a seguinte conotação: "quer dizer interesse em materializar de modo adequado uma significação (sugestão ou propósito, fim), em forma objetiva, por meio de materiais e processos apropriados." (Dewey, 1979a, p. 208, aspas do autor) Estas atividades cumprem a função de dar consciência e medida das aptidões da criança. Se não houver transição de interesse, a brincadeira ou jogo podem se degenerar em peraltices, a criar um mundo imaginário e fantasioso com prejuízos morais. Podemos resgatar essas idéias no seguinte excerto do trabalho de Dewey:

Quando resultados razoavelmente remotos e de caráter definido são antevistos e se empregam esforços persistentes para consegui-los, os jogos ou brinquedos transformam-se em trabalho. Bem como os jogos, este significa atividade com um objetivo e não difere dos mesmos pelo fato de ser a atividade subordinada a um resultado exterior e sim porque a idéia de um resultado a conseguir ocasiona uma atividade mais duradoura. Requer maior continuidade de atenção e maior emprego da inteligência para a escolha de adaptação dos meios necessários. (Dewey, 1979b, p. 225)

Dewey observa que a noção corrente que atribui ao trabalho a idéia de uma atividade subordinada a resultados materiais ulteriores exclui a idéia de significação intrínseca desenvolvida com o emprego de sentimentos, imaginação ou pensamento. O trabalho manual 
ou industrial é assumido como trabalho penoso ou tarefa. A atividade se realiza por compulsão ou coação externa, onde os esforços são maquinais, guiados apenas pelo desejo de completar a atividade, para se evitar um castigo ou receber alguma recompensa. Outro sentido de trabalho é o econômico, que implica uma relação de valor como meio de troca por dinheiro, que permite a troca por outras coisas de valor mais direto.

A brincadeira, o jogo e o trabalho ${ }^{35}$ trazem implicações educacionais importantes principalmente para uma educação que se pauta por ocupações ativas, como forma de apreender e descobrir significações, conforme Dewey elaborou. O jogo e o trabalho são, para Dewey, "os instrumentos mais diretos para atingir-se tal extensão das significações. (...) Fornecem centros vitais para o recebimento e a assimilação dos conhecimentos informativos." (Dewey, 1979b, p. 229) No ambiente extra-escolar, um resultado educacional é geralmente um subproduto um tanto acidental da brincadeira ou trabalho. A presença das brincadeiras, jogos e trabalhos na escola exige organizar um ambiente para que eles contribuam tanto para a aquisição de habilidades manuais, eficiência técnica e satisfação imediata, quanto para o adequado desenvolvimento mental, social e moral. Citando Dewey: "Em suma os fundamentos para se dar aos jogos e ao trabalho ativo um lugar definido no currículo são intelectuais e sociais, não constituindo eles, apenas, expedientes temporários ou prazeres passageiros." (Dewey, 1979b, p. 215)

As crianças necessitam tanto de brinquedos como de jogos e trabalhos. Mesmo na atividade infantil pode se introduzir certa dose de trabalho, na medida em que a criança esteja pronta, ou amadurecida para "agir na base de uma idéia", caso contrário se detém arbitrariamente seu desenvolvimento e se fixa num nível de excitação sensorial (cf. Dewey, 1959b, p. 150-151) Acrescenta Dewey:

[...] não há, pois, nenhum fundamento para a suposição de que as crianças de jardins de infância não sejam capazes senão de brinquedos de fazer de

\footnotetext{
${ }^{35} \mathrm{O}$ sentido de trabalho, no campo da educação, é o seguinte: "trabalho significa atividade dirigida pelos fins que o pensamento propõe ao indivíduo, como coisa a realizar; significa engenho e incentiva para escolher meios próprios, para traçar planos; assim, significa, em suma, que as expectativas e as idéias são verificadas nos resultados reais." (Dewey, 1979a, p. 209) Algumas das modalidades de trabalho que Dewey menciona são as seguintes: "Pinturas, desenho, modelagem, canto, desde que exista atenção consciente nos meios - na técnica de execução, estão aí incluídos. Incluídas aí estão todas as formas de treino manual, trabalhos de madeira, de metal, de tecelagem, de costura, de cozinha, etc., desde que não sejam simples tarefas subordinadas a modelos que dispensem a necessidade de reflexão. Na mesma categoria ainda se colocam os aspectos manuais da pesquisa científica, a coleção de materiais para estudo, a manipulação de aparelhos, a sequiência de atos necessários para realizar e anotar experiências." (Dewey, 1959, p. 152)
} 
conta`, enquanto as crianças de escola primária não devam ter outra atividade senão a de trabalho, sem nenhum jogo ou brinquedo. (Dewey, 1959b, p. 151)

Para Dewey, as atividades educativas que limitam o aluno a seguir prescrições e ordens ou reproduzir modelos pré-definidos não contribuem para o aluno desenvolver a percepção para elaborar os fins, nem reflexão para selecionar e adaptar os meios. (cf. Dewey, 1979b, p. 217) Adquirir apenas habilidade muscular através de treino ou trabalhos manuais, a fim de assegurar resultados exteriores perfeitos é um erro educacional. Diz Dewey: “Adquirese a técnica independentemente do objetivo da descoberta e da verificação, que, só ele, daria significação àquela.” (Dewey, 1979b, p.218)

Por outro lado, a atividade que se orienta pela atitude criadora e construtora do aluno exige o cuidado para não descambar em projetos complexos, além das capacidades e condições. Diz Dewey acerca da intervenção do professor nestes casos: "será culpa do professor se o educando não perceber no devido tempo a deficiência de suas realizações, e desse modo, não tiver um estímulo para tentar dedicar-se a exercícios que aperfeiçoem suas aptidões." (Dewey, 1979b, p.217)

O outro significado importante destas ocupações humanas ativas deve-se ao fato delas representarem situações sociais. Assim atividades que envolvem alimentação, habitação, vestuário, produção e comércio, etc., são necessidades da vida, portanto, de interesse comum e fundamental para o homem e, desta forma, uma natural tendência infantil. Certas críticas erram ao reduzir estas atividades de trabalho ao seu valor rotineiro e utilitário, ou um ganhapão, ou são consideradas a partir dos limites impostos pela indústria, em cujas condições elas não passam de um mal a ser suportado em vista da sobrevivência. Esta é uma visão exterior de trabalho. Dewey propõe vê-lo a partir do interior, como atividade reflexiva ou ação inteligente, na qual e pela qual os conceitos ou significações são construídos e se adquire familiaridade com métodos de investigação e verificação. Mesmo que para o adulto certas atividades sejam rotineiras, para a criança elas são vivamente significativas. Interessar-se pelo mundo das ocupações do adulto e se envolver com ele é, para Dewey, "exercitar a imaginação na construção de uma experiência de mais amplo valor, que qualquer outra que a criança já tenha adquirido.” (Dewey, 1979a, p. 212) À medida que se dedicam a estas atividades, os alunos descobrem problemas interessantes, transferindo seu interesse para a investigação intelectual sobre os mais amplos aspectos da vida humana, inclusive os que são tratados pelas ciências sociais. Por exemplo, a jardinagem poderá despertar problemas de germinação, nutrição dos vegetais, produção de frutos, insetos e animais, convivência humana, etc. Todas 
estas atividades e seus resultados se revestem de um valor social, como qualquer outra descoberta, como a roda, a eletricidade, etc. Portanto, estas atividades têm valor científico e social. Mas, julgar a atividade do trabalho do aluno, sob o critério do valor do produto segundo os referenciais costumeiros, ela perderá a importância. Indica Dewey o procedimento: "Deve julgá-lo sob o ponto de vista do plano, da invenção, do engenho, da observação, exercitados pelo imaturo, tendo sempre em mente que aquilo que é para ele história velha pode provocar emoção e pensamento na criança. (Dewey, 1979a, p. 210) Quando o trabalho estiver associado à atitude de jogo, ele adquire a qualidade de arte.

A organização do programa da escola elementar em torno de projetos educativos tem como base a potencialidade intelectual e social das diferentes artes, profissões e ocupações. Dewey apresenta algumas condições para que os projetos sejam educativos.

Interesse: Emoções, desejos, energia canalizada em torno de algo de significado para o indivíduo alimentam a atividade. $\mathrm{O}$ objeto do interesse tem ser explicitado

Valor intrínseco na atividade: As atividades têm que ter certa qualidade, não podendo ser trivial ou ter como conseqüência o mero prazer imediato.

Apresentar problemas que despertem a curiosidade: A atividade produz indagações que conduzem à busca de informações a serem conseguidas pela observação, leitura, e outras fontes fidedignas.

Prolongamento: $\mathrm{O}$ desenvolvimento da atividade deverá ter continuidade, consecutividade, cumulatividade e consequiência. Assim o tempo de sua duração deve ser adequado para se poder organizar o material.

\subsection{Educar e escolher atividades educativas}

$\mathrm{Na}$ condução do processo educativo deve-se evitar a chamada monotonia, que significa parada de desenvolvimento e de crescimento, ausência de felicidade e bem-estar. Este problema não se combate promovendo um prazer resultante de uma reação momentânea imediata. Deve-se oferecer condições para o crescimento progressivo que gera emoção, alegria e felicidade, emoções genuínas de quem se absorve com interesse no que faz: "As emoções que acompanham o crescimento progressivo do curso de uma ação, de um movimento contínuo de expansão e realização, constituem a felicidade; paz ou contentamento mental a que, se vivo e forte, chamamos alegria." (Dewey, 1979a, p. 113) 
A crítica de Dewey sobre a escolha das atividades vem da constatação de que elas ficam expostas aos fatores de arbitrariedade, das tradições escolares, das "ondas de efêmeras fantasias pedagógicas", correntes sociais. Outro fator deve-se aos precários resultados dos que iniciam com o método empírico, provocando o abandono de atividades externas e o apego a matérias e métodos puramente teóricos.

$\mathrm{O}$ aspecto positivo da dificuldade de escolha de atividades educativas indica que as oportunidades são também indefinidamente maiores. O problema de descobrir e organizar as ocupações úteis, problema este considerado por Dewey como o mais importante da educação, exige que sejam pesadas três condições:

[...] (a) que sejam mais afins, mais bem adaptadas ao estágio imaturo de desenvolvimento; (b) que sejam mais promissoras, como preparo para as responsabilidades sociais da vida adulta; (c) que, ao mesmo tempo, tenham a máxima influência sobre a formação de hábitos de observação penetrante e de inferência consecutiva. (Dewey, 1979a, p. 59, itálicos do autor)

Algumas das atividades a que Dewey se refere são ocupações ou trabalhos manuais: jardinagem, cozinha, tecelagem, coisas simples de ferro e madeira, excursões, artes gráficas, além de laboratórios, oficinas e jardins, uso de dramatizações, brinquedos e jogos. Tratam-se, diz ele de "medidas práticas adequadas ao eficaz desenvolvimento da reflexão e dos hábitos de pensamento". Por elas, continua Dewey, "existem oportunidades para se reproduzirem as situações da vida, e para adquirir e aplicar informações e idéias na realização de experiências progressivas (...) Os conhecimentos vitalizam-se com o ser postos em ação, com o exercerem a sua função na direção das atividades.” (Dewey, 1979b, p. 178) As crianças têm propensão para as atividades, estas aproveitam o que há de mais primário e inato nas tendências infantis, são oportunas para realizar um "serviço social eficiente e seguro de si mesmo." (Dewey, 1979a,p. 214). Mas, seguidamente, são adotadas mais por razões utilitárias do que pedagógicas. Podem também ser ensinadas pela rotina, pela imposição, pela convenção. Dewey defende o planejamento de um "trabalho inteligente e consecutivo" em relação às atividades, de acordo com os seguintes fatores: em primeiro lugar está, como foi dito, o interesse, o uso das emoções e desejos, que canalize as energias de maneira significativa para o indivíduo. Em segundo lugar, que os objetos ou ações sejam aproveitados pelos seus valores intrínsecos, ou seja, como "instrumentos de formação de hábitos intelectuais vivos, persistentes, eficientes." O terceiro fator imprescindível no planejamento das atividades é a:

[...] apresentação de problemas típicos que devam ser resolvidos por reflexão e experimentação pessoal e pela aquisição de conteúdos definidos de conhecimentos capazes de levar, mais tarde, a noções científicas mais 
especializadas. [...] uma familiaridade com métodos de investigação e prova experimental. (Dewey, 1979a, p. 214)

O quarto fator é a necessidade de prolongamento dos projetos, a fim de que se consiga sua adequada execução com continuidade, consecutividade e cumulatividade, em relação aos passos e campos por onde se desenvolve.

\subsection{Filosofar e filosofar sobre a Educação}

Para Dewey existe uma articulação muito íntima entre filosofia, ciência e educação a ponto de definir a filosofia como a teoria geral da educação.

A filosofia trata dos problemas que se originam do conflito na vida social: conflito entre interesses organizados e exigências institucionais. Requer uma atitude de totalidade, ou seja, a necessidade de integrar e harmonizar os vários interesses em conflitos.

Dewey considera a filosofia desnecessária, quando os interesses sociais são superficiais demais, que acabam se fundindo, ou quando não estão organizados suficientemente a provocar conflitos entre si. É necessária a discrepância de ideais de conduta que atingem amplamente a sociedade e exigem um reajustamento. Exemplos de conflitos podem ser:

[...] o interesse científico se contrapõe ao religioso, ou o econômico ao científico ou estético, ou quando o interesse conservador pela ordem existente entra em conflito como progressivo interesse pela liberdade, ou quando o institucionalismo se embate com o individualismo, nasce um estímulo para se descobrir algum ponto de vista mais compreensivo, donde as divergências possam ser harmonizadas, e possa ser restaurada a compatibilidade ou continuidade da experiência. (Dewey, 1979b, p. 360)

Os sistemas filosóficos formulam estes problemas tornando explícitas, a partir de determinadas concepções, as relações de conflitividade e incerteza do homem com a natureza, consigo mesmo e com os outros. Neste caso, a filosofia tenta captar aquilo que constitui a qualidade de sua experiência.

Dewey aceita em seu conceito de filosofia a qualidade de "amor à sabedoria" no sentido de procedimento e direção da vida. Três aspectos acompanham a prática filosófica para Dewey: "a filosofia foi geralmente definida de modo a implicar uma certa totalidade, generalidade e última causalidade (ultimateness) da matéria e do método." (Dewey, 1979b, p. 357_324) Compreender a matéria é buscar a unidade ou seus princípios finais. A atitude 
filosófica se revela no "esforço para conseguir-se uma visão de experiência a mais unificada, coerente e completa possível." (Dewey, 1979b, p. 357)

Os aspectos da totalidade, generalidade e última causalidade denotam uma atitude em relação ao mundo, especialmente em relação ao conhecimento. Este é o critério que Dewey utiliza para diferenciar a filosofia da ciência. O conhecimento fundamentado dos fatos, suas causas e leis é tarefa das ciências, como a física, química, biologia, história, matemática, etc. Diz Dewey: “Às ciências é que compete dizer quais as generalizações admissíveis sobre o mundo e quais, especificamente, são elas.” (Dewey, 1979b, p.358) Já a filosofia é pensar a atitude a ser tomada diante do conhecimento: "Filosofia é pensar o que aquilo que é conhecido requer de nossa parte - qual a atitude de correspondência que ele exige. É uma atitude do que é possível, e não um registro de fatos consumados. Por esta razão é hipotética, assim como todo ato de pensar." (Dewey, 1979b, p 358/359)

A totalidade é a atitude filosófica de continuidade, ou seja, a prontidão e coerência no modo de reagir considerando as significações e a pluralidade de coisas que acontecem. Ela mantém o equilíbrio na multiplicidade de atos de forma a garantir a transmissão e o enriquecimento das significações; é um hábito ativo: "o prosseguimento de um primeiro hábito de agir com a readaptação necessária para conservá-lo vivo e em evolução.” (Dewey, 1979b, p.358) Assim, a totalidade denota uma atitude de aprender: "a característica da filosofia é a capacidade de aprender, de extrair significações até das desagradáveis vicissitudes da vida e transformar aquilo que foi aprendido em aptidão para continuar a aprender." (Dewey, 1979b, p. 359) Dewey entende os aspectos da generalidade e última causalidade de forma análoga. Última causalidade significa uma disposição para penetrar níveis mais profundos das significações extraídas, das relações de todos os acontecimentos, negando-se a considerar a experiência como algo finalizado e esgotado; generalidade busca compreender o ato na sua relação com o toda a que pertence, e que lhe dá significação, negando o isolamento dos mesmos.

Decorre daí a identidade da filosofia com o pensar, que é distinto do conhecimento estabelecido, do registro de fatos consumados e sistematizados pela ciência. Atividade filosófica é o pensamento que volta sobre o que foi pensado, permitindo pensar seu novo direcionamento: "Pode-se quase definir a filosofia como o pensamento que se tornou consciente de si mesmo - que generalizou seu lugar, função e valor na experiência." (Dewey, 1979b, p. 359) 
A especialização da filosofia, na medida em que utiliza uma linguagem técnica diferente da usada pelo povo dissimula os problemas filosóficos. Estes aparecem somente quando o conflito da vida social se generaliza e é sentido pela ampla maioria da população. Por isso, passam a ser problema da filosofia e da educação. A filosofia busca formular esses problemas relacionados aos vários interesses sociais e gerais e elaborar hipóteses e métodos para um melhor equilíbrio de interesses. A educação aparece, então, como um "terreno vantajoso para penetrar na significação humana das discussões filosóficas." (Dewey, 1979b, p. 361) Isto porque as autênticas conclusões filosóficas sobre os conflitos nunca são coisas remotas da vida e, portanto, influenciam a atividade educativa e consequentemente a conduta. Caso contrário, estas conclusões permanecem apenas verbais, simbólicas e, portanto, são completamente artificiais. Assim a exigência para a educação é de tratar os problemas no "terreno em que surgem e lutam, em sua própria casa", diz Dewey, porque é a única maneira de trazer diferenças práticas. Portanto, a educação como formadora desta atitude mental, sentimental e moral sobre a conduta se identifica com a atividade filosófica: "Se quisermos conceber a educação como o processo de formar atitudes fundamentais, da natureza intelectual e sentimental, perante a natureza e os outros homens, pode-se até definir a filosofia como a teoria geral da educação." (Dewey, 1979b, p.362)

Dewey atribui duas tarefas à filosofia em relação aos fins da ciência: por um lado, a de criticar os objetivos da ciência, apontando os valores obsoletos e os meramente sentimentais; por outro lado, a de interpretar o alcance social dos resultados da ciência especializada. (cf. Dewey, 1979b, p. 362) Para realizar esta tarefa a filosofia necessita da mediação da educação. Assim, Dewey articula estas três dimensões: ciência, filosofia e educação:

Nas artes mecânicas, as Ciências tornam-se meios de tratar as coisas de modo a utilizar suas energias para objetivos determinados. Por meio das artes educativas a filosofia pode engendrar métodos para utilizar as energias dos seres humanos de acordo com as concepções sérias e profundas sobre a vida. A educação é o laboratório onde as distinções filosóficas são concretizadas e postas à prova (Dewey, 1979b, p. 363)

Dewey argumenta que a origem da filosofia entre os atenienses decorre de uma necessidade educacional. A filosofia começa como especulação da natureza. Os sofistas passam a utilizar os resultados e métodos desta especulação primeira sobre a natureza para pensar a conduta humana. Estes primeiros professores passam a se preocupar com a instrução dos jovens nas questões da virtude, da política, das coisas da cidade e das coisas domésticas. Esta passagem é muito significativa para a filosofia, diz Dewey, pois, passa a se configurar 
como atividade que trata das relações entre particular e universal, teoria e prática, compreendendo a virtude a partir da ação. Diz Dewey: "a filosofia começou a tratar das relações do individual com o universal, com alguma classe compreensiva ou com algum grupo; da relação do homem com a natureza, da tradição com a reflexão; do conhecimento e ação.” (Dewey, 1979b, p. 363)

Na medida em estas questões passaram a ser discutidas em si mesmas costituíram um ramo independente de investigações da filosofia, afastando-se da educação. Este fato não significa que a educação se reduza a uma aplicação destas idéias desenvolvidas pela filosofia. Dewey esclarece o vínculo da filosofia com a educação:

A "filosofia da educação" não é a aplicação exterior das idéias já feitas a um sistema de prática escolar que tivesse origem e meta radicalmente diversas: é apenas uma formulação explicita dos problemas da formação de uma mentalidade reta e de bons hábitos morais, tendo-se em vista as dificuldades da vida social contemporânea. A mais profunda definição de filosofia que se possa dar é a de ser a teoria da educação em seus aspectos mais gerais. (Dewey, 1979b, p. 364)

Dewey coloca a necessidade de uma reconstrução da filosofia e a educação diante das mudanças da vida social, da revolução da indústria e do desenvolvimento da democracia. Esta reconstrução implica na reconstrução das idéias e ideais que orientam as mudanças na vida prática

\subsection{Educar para investigar a conduta moral}

A moral consiste num fim unificador e culminante da educação para Dewey. A educação é entendida, não como um simples meio para a vida, mas a própria vida. E vida para Dewey é crescimento. E no crescimento é que reside a própria moral: "O crescimento, o desenvolvimento em si mesmo, é o único 'fim' moral. (Dewey, 1959a, p. 177) A partir desta base, Dewey elabora sua máxima moral: “O mau homem é o que está começando a aruinar-se, que está se tornando menos e menos bom, não obstante o quanto bom tenha sido. O bom homem é o que está se tornando melhor, pouco importando o quanto indigno tenha sido." (Dewey, 1959a, p. 176)

Temos que vincular necessariamente a moral com a própria regra pragmática - “com o fim de descobrir o significado da idéia, indaguemos as consequiências" - para pensar a educação moral. Moralidade e inteligência trabalham conjuntamente. Dewey expressa esta conexão ao afirmar que "em toda situação moral, o julgamento e escolha hão de anteceder a 
ação." (Dewey, 1959a, p. 165). Esta afirmação nos remete ao processo da investigação, como já estudado. Este é o trabalho da inteligência, que é por sua vez acompanhado pela moral:

Nossas falhas morais têm origem em alguma fraqueza de disposição, em alguma ausência de humanidade, em alguma inclinação unilateral que nos faz chegar ao juízo ou à decisão quanto ao fato concreto de modo negligente ou malevolente. A benquerença extremada, a sensibilidade sutil, a persistência em face do desagradável, o equilíbrio de interesses que nos capacita por levar a cabo o trablho de análise e decisão de modo inteligente, são os traços morais distintivos - as virtudes ou excelências morais. (Dewey, 1959a, p. 165-166)

A moral tem íntima conexão com todos os objetivos e valores da educação, manifestando-se nas questões da disciplina, do desenvolvimento da criança, da cultura, do conhecimento, dos métodos e da participação social. A educação que tem por objetivo a formação do caráter é fundamental para uma sociedade democrática, já que esta depende substancialmente das atitudes individuais e das aptidões pessoais. Afirma Dewey: "Moral é toda a educação que desenvolve a capacidade de participar-se eficazmente da vida social." (Dewey, 1979b, p. 396)

Para Dewey, o problema da educação moral no âmbito escolar depende das relações entre o conhecimento e a conduta. Mas este campo tem sido demarcado pelos dualismos entre o interior e exterior, o dever e o interesse, inteligência e caráter. Tais dualismos criam obstáculos e pervertem o processo da educação no percurso de atingir os objetivos da educação moral.

A teoria da moral, que concebe a atividade como composta dos fatores interior e exterior, ou em outros termos, o espiritual e o material como contrários entre si, está assentada em outros dualismos, como o do espírito e mundo, alma e corpo, fins e meios. Nesta teoria, o espírito diz respeito ao que é interior, existe na consciência e é entendido como sendo o caráter e fonte dos motivos da ação; a conduta diz respeito ao que é exterior ao espírito, movimentos ocasionados pelos motivos, e suas conseqüências aparecem como resultados externos e separados do espírito. Criou-se um mundo imaginário de autoridade e autosuficiência da vida interior do espírito. Esta cisão emana de condições sociais hostis que fizeram com que uma dada classe se refugiasse nos seus próprios pensamentos e desejos, não empregando meios para reorganizar o ambiente. Tomaram em conta a indiferença e o desprezo ao mundo exterior e recalcamento da ação em prol do cultivo das idéias. Exemplos desta teoria são o estoicismo, o cristianismo monástico e popular e outros movimentos religiosos dos primeiros séculos da era cristã. Na modernidade, o caso da Alemanha do século 
dezoito e dezenove, e a própria defesa de Kant sobre a boa vontade, como sendo completa em si mesma independente da ação, constituindo ela o único bem moral, revela este dualismo. Reagindo a esta teoria, desenvolveram-se as concepções do hedonismo e utilitarismo, que acentuam a importância daquilo que o homem faz, as conseqüências ou mudanças que resultam de suas ações. A tonalidade da moral passa a ter orientação subjetiva e arbitrária. No ambiente escolar estas teoria reaparecem através das práticas que prezam a obediência aos preceitos impostos, exortações às "boas intenções", e hábitos rotineiros. Para Dewey, sempre que esta tendência moral prepondera, elimina-se a condição orgânica da conduta, ou seja, a atitude do interesse, do desejo consciente e da reflexão deliberada, que proporcionam uma atividade contínua, progressiva e acumulativa.

O outro antagonismo prejudicial à formação do caráter é o que opõe o dever ao interesse. Dever subentende a ação guiada por "princípios", obediência a uma lei, portanto, um proceder desinteressado. O interesse, nesta interpretação, tem o sentido de proceder egoísta, atendendo às vantagens pessoais de acordo com a circunstância. $\mathrm{O}$ argumento de defesa do interesse se baseia a na afirmação de que mesmo no agir por princípio ou dever há um resultado positivo para si, força que motiva a ação por certos objetos ou idéias, daí o interesse próprio. $\mathrm{O}$ argumento do agir por princípio considera que toda abnegação e sacrifício exigidos para uma ação estão sob a tutela do dever e não do interesse. Desta forma entrincheirados, o dever e o interesse revelam a cisão entre o eu individual e o interesse. $\mathrm{O}$ eu tem a conotação de "qualquer coisa fixa ou feita, completa e isolada", anterior à ação e que busca adquirir coisas como virtude, fama, poder, lucro, prazer, etc. O equívoco desta distinção está no fato de colocar o eu como um fim e o interesse por objetos, idéias, atos e pessoas como meios. Não se leva em conta que o eu é "uma coisa em formação contínua por meio da escolha da atividade" (cf. Dewey, 1979b, p. 386_ 351) O dualismo entre eu e interesse é baseado nesta falsa concepção. Diz Dewey:

O fato é que o eu e o interesse são dois nomes para designarem uma coisa única; a espécie e a intensidade do interesse ativamente tomado por alguma coisa revelam e medem a qualidade do eu existente. Basta ter-se em mente que interesse significa a identificação ativa e operante do eu com certo objeto, para cair por terra aquele pretenso dilema. (Dewey, 1979b, p. 386)

A generosidade, por exemplo, não pode ser ação de indiferença maquinal, mas implica interesse no que se faz, e identificação do eu com toda a série de relações implicadas na ação, de forma a readaptar e expandir o eu a partir das conseqüências observadas. 
Dewey assevera que proceder por princípio em unidade com o interesse é conduzir a atividade de forma contínua. Princípio refere-se ao curso da ação e não a circunstâncias ocasionais: "O princípio não é aquilo que justifica uma atividade e, sim, é apenas outro nome para a continuidade da atividade." (Dewey, 1979b, p. 388_353) O melhor modo de agir se depreende da percepção das conseqüências de um curso da atividade e não de um agir por princípios abstratos, que poderão até agravar um mal que se pretende evitar. Aprender com a experiência como melhor método de agir é a orientação deweyana. O princípio afastado do curso da atividade pode ser cego. Decorre desta percepção, a importância de pensar as condições escolares para uma atividade de manifesto interesse e desejo contínuo, unificado e acumulativo, de construção das significações. A motivação intrínseca à ação proporciona o enfrentamento da distração e obstáculos. O apelo aos princípios não passa de verbalismo.

Outro antagonismo no campo da moral surge da divisão entre inteligência e caráter. A moral é identificada com a razão, como na tese kantiana que a coloca esta como a única e genuína agência dos motivos da moral. A moral é elevada a uma instância à parte aos demais conhecimentos ordinários, afastada da inteligência prática.

$\mathrm{Na}$ educação, este antagonismo corresponde à distinção e desvinculação entre desenvolvimento do caráter como fim supremo e a aquisição dos conhecimentos e desenvolvimento da inteligência. Enquanto estes tomam a maior parte do tempo e atividades escolares, a formação do caráter é feita à parte, e na base de lições de moral, ou catequese sobre a virtude e o dever pré-estabelecidos pela autoridade.

O autor inclui neste dualismo em discussão, como concepção extremada em relação à anterior, a tese socrático-platônica e aristotélica. Platão defendeu que a prática consciente de um mal era devido ao desconhecimento do bem. Para Dewey, ele não levou em conta que o fator decisivo para a prática é o hábito e não o conhecimento. Aristóteles defende a virtude moral análoga a arte da medicina, em que se confia mais num médico experiente do que noutro que tenha conhecimentos teóricos. A crítica de Aristóteles ao ensino de Platão não levava em conta que, para este, o conhecimento é resultado de uma prática disciplinada. A compreensão do bem se consegue por educação prolongada, uma recompensa pelo esforço e pelo amadurecimento da experiência.

Para Dewey, o conhecimento do bem só pode ter significação se tiver o crivo da ação, ou seja, se uma satisfação foi devidamente experimentada. $\mathrm{O}$ conhecimento que atende às exigências da experiência é o que influi na conduta. Por isso, o conhecimento livresco produz apenas um efeito na conduta, que é o da repetição quando solicitado; o mesmo ocorre 
com uma especialidade isolada e técnica do conhecimento, que fica restrita aos próprios limites, não interferindo na conduta. Assim, o problema educacional da moral é o de relacionar os conhecimentos com os impulsos e hábitos no curso da atividade. Diz Dewey:

Aquilo que é aprendido em uma ocupação que tenha um objetivo e implicando cooperação com outras pessoas é conhecimento moral, quer o considerem, ou não, conscientemente como tal. Pois ele cria um interesse social e confere a compreensão necessária para tornar esse interesse eficaz na vida prática. Precisamente porque os estudos do programa representam padrões para a vida social, eles constituem os órgãos para iniciação nos valores sociais. (Dewey, 1979b, p.392_356)

Assim, a aquisição de conhecimentos depende de condições que permitam a experiência compartilhada que impregna de espírito social, critério mais importante para a educação moral. Pode-se adquirir conhecimentos e aprender a linguagem em relativo isolamento. Entretanto, é na contextura dos trabalhos e jogos associados a outros indivíduos que se compreende a significação dos sinais lingüísticos, além da aquisição da cultura, o desenvolvimento natural e social que são características morais. A meta da educação é o crescimento do indivíduo como membro digno de uma sociedade, isto é, viver de forma que o que recebe dos outros se equilibre com a sua contribuição para a vida dos outros. $\mathrm{O}$ que materialmente participa nesta relação de receber e dar são as significações que servem de oportunidades e meios para a evolução da vida. "Aquilo que ele recebe e dá como ser humano, como ser dotado de desejos, sentimentos e idéias, não são bens exteriores e sim um expandir-se e um aprofundar-se da vida consciente - uma compreensão mais intensa, disciplinada e ampla das significações." (Dewey, 1979b, p. 395_359)

As qualidades do espírito ou da mente são qualidades morais. Se impostas como normas pela autoridade, configurando-se uma conformidade externa, elas perdem seu valor ético e, mesmo produzindo resultados morais, estes são indesejáveis numa sociedade democrática. 
É difícil traçar no fenômeno a linha divisória entre as tendências pessoais e as tendências sociais: a vida resumida do homem é um capítulo instantâneo da vida de sua sociedade... Acompanhar a primeira é seguir paralelamente e com mais rapidez a segunda; acompanhá-las juntas é observar a mais completa mutualidade de influxos

Euclides da Cunha, Os Sertões

\section{CONSIDERAÇÕES FINAIS}

Investigar a importância do conceito no pragmatismo deweyano evidenciou um conjunto amplo de noções correlacionadas que sustentam esta filosofia. O empreendimento deweyano é o de reconstruir os conceitos, reconstruindo a filosofia. Procuraremos evitar, agora, repetir todos os nexos abordados ao longo desta pesquisa. Levantamos algumas considerações que, a nosso ver, são relevantes diante do problema trabalhado.

Uma primeira questão nos leva ao momento histórico do surgimento do Pragmatismo e do desenvolvimento das teses deweyanas. A textura cultural americana da segunda metade do século XIX e início do século XX proporcionou condições favoráveis para o desenvolvimento das idéias nas áreas da filosofia e ciência. É um período de transformações e conflitos econômicos, sociais e políticos. Teorias inovadoras estão aparecendo, como é o caso do Evolucionismo. Novos estudos sobre a origem do homem, do pensamento e da linguagem, dos problemas da sociedade, dentre tantos outros, estão na pauta do dia. Este ambiente original da cultura americana favoreceu a produção da pesquisa no âmbito acadêmico, onde atuam os primeiros criadores desta corrente de pensamento. Os filósofos pioneiros do Pragmatismo souberam responder aos conflitos e incertezas da civilização, desenvolvendo um corpo conceitual específico, como uma maneira de ver e resolver os problemas. E a resposta original foi encontrada sugerindo um método que desafiava a natureza das crenças, da razão e da verdade das filosofias mais antigas. O método compreendia que a função da inteligência é a solução criativa de problemas. A regra de ouro do método, cunhada por Peirce, é considerar todo pensamento ou toda concepção a partir da soma de conseqüências práticas que podem resultar, exercendo influência direta sobre a conduta da vida. Aparentemente simples, a regra foi entendida e levada adiante por cada um dos pioneiros, de maneira bastante original. Peirce desenvolveu o método de pensamento, que consiste numa teoria de análise lógica ou da definição verdadeira. 


\section{Como Dewey pensou o pragmatismo?}

Em sua autobiografia, Dewey afirma ser a própria experiência de vida um fator importante para intuição de sua filosofia. A vida na família, sua educação, a experiência religiosas e os demais embates e envolvimento com os problemas da época, como podemos ver através de sua biografia, constituem um traço marcante na elaboração de sua filosofia.

Um dos problemas que o deixava preocupado era o dos dualismos - matéria-espírito, corpo-mente, indivíduo-sociedade, conhecimento-prática, etc. - da filosofia, da psicologia, da religião e da educação, e suas repercussões na vida pessoal, social, política, educacional. Tais dualismos traziam conseqüências trágicas, como a perniciosa divisão da sociedade em classes ou castas. Indicava que alguma coisa não andava bem nestas maneiras de conceber o mundo e tinha que ser melhor equacionada.

Dewey empreende uma releitura da própria da história filosofia, dos gregos aos seus contemporâneos. A filosofia é uma fonte fértil de conceitos. Entretanto, os conceitos da filosofia tradicional estão construídos sob a lógica da imagem abstrata, cópia da realidade, representação mental das coisas ou do a priori da mente, ou resultante da relação entre estas concepções. Dewey questiona o lugar e o papel dado à experiência e ao pensamento no campo da filosofia. Sua análise mostra como a experiência foi relegada a uma categoria inferior, ao mundo da vida, da sobrevivência, da opinião, do corpo, do fragmentário e movediço, desclassificada como possibilidade e garantia para qualquer conhecimento verdadeiro. Dewey encontrou na síntese hegeliana (sujeito-objeto, matéria-espírito, divino-humano) uma forma de reintroduzir o valor da unidade da experiência. Na raiz da experiência está a vida, e o pensamento é o instrumento que o homem tem para garantir sua sobrevivência. A teoria darwiniana da evolução naturalista oferecia um aparato conceitual para entender a relação integrada do organismo com a natureza. Dewey transpôs esta interpretação para o campo da filosofia. A experiência inteligente é a forma ativa dos organismos reagirem para continuarem vivos através da interação com o meio. Mudanças, conflitos, desarranjos, problemas surgem a todo o momento na experiência. A inteligência aparece como instrumento da readaptação para continuar a sobrevivência. A sobrevivência é a primeira função da inteligência. Ela é o instrumento de fabricar instrumentos tecnológicos para tornar mais apto o organismo no seu processo de adaptação e sobrevivência. Os instrumentos são aperfeiçoados pelo o uso e, neste processo, a própria inteligência cresce. O caráter dinâmico da experiência é responsável pela variedade e mutabilidade na natureza. 
Dewey mostra como a ciência foi germinada neste âmbito, exatamente porque lidava com a experiência, onde o critério pragmático exerce sua função. O uso de instrumentos foi cada vez mais sendo apurado. Daí surgiu a matemática, e o uso deste instrumento, e também a criação de outros mais adaptados para trabalhar em outras experiências, produziu verdadeiras revoluções. Mas, a ciência não se ocupa de uma descrição do mundo tal como ele funciona. Ela se ocupa com os aspectos que são acessíveis à observação nas situações em que há um observador que poderá ampliar infinitamente suas observaçõs com a ajuda de instrumentos. Dewey recolocar a norma pragmática em termos de relações de causa-consequência. E tudo o que serve a esta regra é instrumento e, por sua vez, conceito. O sentido das coisas significa o seu uso possível na geração de outras coisas, que serão experiênciadas no futuro. Daí decorre que o conceito como instrumento consiste num plano de ação. Ele é hipotético, antecipativo, previsor, e, por conta disso, instrumento de controle e guia da ação, meio para executar operações em vista de um determinado fim. James havia mostrado como os princípios darwinianos auxiliam a explicar os processos conscientes e a mente. Dewey dispunha de elementos da psicologia da mente de James para reconstruir muitas de suas bases sobre adaptação do ser humano ao meio. Completa-se o primeiro circuito do giro reconstrutivo, a partir da unidade evolucionista-hegeliana do conceito: a continuidade e interação entre organismo, experiência, natureza, inteligência, instrumento, ciência. Evidentemente que não podemos excluir deste quadro a linguagem, o instrumento dos instrumentos. A linguagem como instrumento natural com o qual nos equipamos para lidar com o meio. Ele descarta a noção de representação na qual a linguagem cumpre a função de ser espelho da natureza e coloca o homem na condição de expectador. Além disso, nesta concepção, a própria linguagem passa a ser uma entidade autônoma, um meio representacional entre nós e uma realidade fixa. A função do pensamento e da linguagem não é a especulação, para Dewey. Ambos são originários da relação adaptativa do organismo e meio, e suas funções são eminentemente práticas. É a de ser um instrumento de trabalho para a manutenção da vida. Ela é imprescindível para desenvolver os conceitos, que são planos de ação. O aprimoramento deste poderoso instrumento dá-se na e para a experiência.

A experiência, possibilitada pela relação contínua e interativa do organismo e meio, tem uma dimensão social. A sobrevivência humana se dá pelo caráter genético social do homem. O conceito é um instrumento socializador. A interdependência e cooperação fazem parte da natureza humana, assim como um vasto conjunto de necessidades sociais, como a amizade, o governo das coisas comuns, a expressão e apreciação estéticas, etc. É pelo 
processo de associar-se que o ser humano, não só supre melhor suas necessidades básicas, mas, de maneira especial, expande sua experiência trocando e transmitindo idéias, emoções e valores. O conceito, como instrumento que permite a universalização, opera como um denominador comum, que liga o indivíduo ao social, proporciona o sentimento e a consciência de pertença ao todo. A experiência de vida associada, inter-relacionada, comunicada, constitui para Dewey a vida democrática. Democracia é um conceito ideal que, diferentemente dos demais, só pode ser entendido a partir de uma atitude de fé, da moral e da educação. Atitude de fé porque é a única forma de vida digna do ser humano, mesmo sabendo que nenhuma experiência democrática é completa. Fé não denota uma religião particular, mas uma intuição singular da religação com os outros e com a natureza. Atitude moral, porque implica uma escolha, decisão. Para isso, é preciso investigar e deliberar sobre as melhores hipóteses, dando oportunidade para escolhas que ofereçam ao organismo a interação que garanta a continuidade da vida no presente e no futuro. Estas escolhas (conceitos-crença) se traduzem em condutas, em ações práticas, que modificam o organismo e o meio. Tais mudanças criam um novo ambiente e, como a ciência mostra, muitas delas, no limite, são irreversíveis.

Educacional, porque é a forma de vida que favorece o crescimento do organismo individual e social. Pela educação é possível manter a continuidade da cultura, crenças, valores, hábitos, instituições, etc.

Assim sendo, pensamos que é possível encontrar os seguintes nexos na concepção de conceito de Dewey:

Conceito e natureza: O conceito é inerente à vida. É o elemento inteligente da natureza e do organismo vivendo em virtude de um ambiente. As primeiras aquisições de uma criança, ainda no âmbito de domínio de seu corpo, são aquisições orgânicas e psíquicas, que exercem a função do conceito.

Conceito e experiência: O conceito é o elemento inteligível da experiência. Os conceitos constituem a parte da experiência que é conhecida (significações familiares) e conduzida por hábitos. Eles garantem a continuidade da experiência. São elementos que não nos interessam alterar, corroboram com a adaptação do organismo, tornam econômica e funcional as ações do indivíduo. Entretanto, nenhum conceito tem a garantia de ser absoluto e imutável. Eles são hipotéticos. Os elementos determinados da experiência - os conceitos coexistem com os elementos indeterminados. Surgem situações problemáticas, que exigem do organismo uma nova resposta. A situação problemática poderá ser resolvida com uma 
significação oriunda do repertório acumulado de significações ou hábitos ou exigirá que o pensamento modifique ou crie uma nova significação.

Conceito e hábito: Os conceitos são retenções orgânicas de significados em resposta a situações problemáticas anteriores. Eles constituem as formas de agir suficientemente gerais. Eles agem como hábitos. Quando os conceitos adquirem estrutura fixa e resistem às mudanças, os hábitos são rotineiros. Assim, como a resposta do organismo ao meio é fixa ela tende a inibir o crescimento. Os hábitos podem ser ativos. Neste caso, sobressai o papel da inteligência reflexiva que antecipa na imaginação as possíveis conseqüências, oferecendo a possibilidade da escolha da melhor alternativa. Desta forma, o hábito corrobora com o crescimento e dá mais liberdade para o indivíduo, ou seja, lhe dá poder para agir.

Conceito e investigação: Os conceitos atuam na forma de hipóteses (ideacionais). Estas hipóteses funcionam como direção e controle das operações de observações (material perceptivo). São provadas e revisadas com base nas conseqüências que produzem, na aplicação prática (função experimental do conceito). Unificam a situação problemática através da asserção garantida. Estas asserções garantidas criam o verdadeiro em termos empíricos experimentais. A verdade é engendrada neste processo e resulta da prática. Ela não é anterior ao processo, resulta dele. As operações conceituais na investigação refletem e encarnam o contínuo experiencial estabelecido, tanto pelas condições biológicas como culturais. Permitem, assim, a reorganização progressiva e cumulativa de condições antecedentes, tendo em vista a ação futura. O estudo dos métodos de solucionar problemas e dos instrumentos desenvolvidos para este fim (termos, conceitos, juízos, inferências, conhecimento, verdade, etc.) e seu potencial de aperfeiçoamento define o campo da lógica. Ela é a teoria da investigação. Como a prática investigativa não tem outro fundamento a não ser o estudo dos processos que a constituem, ela é, também, um instrumento de criação humana, portanto, contingente, histórica, modificável, evolutiva.

Conceito, educação e democracia: Os conceitos são instrumentos para a significação e transmissão da experiência através da comunicação. A produção e aperfeiçoamento dos instrumentos na experiência é essencial para vida em contínua mudança. Educar é aprender a usar e melhorar continuamente os instrumentos. Aprende-se fazendo. Por isso, aprender é aprender a aprender a pensar. Aprender com esforço deliberado, desenvolvendo as etapas do processo de solução efetiva de um problema, é essencial para o progresso da inteligência. Este processo forma o cabedal de conceitos e habilidades, tornando os indivíduos e a comunidade melhor aparelhada para solucionar novos problemas. Por sua 
vez, a educação é um processo que dura a vida toda, considerando que a necessidade de solucionar problemas nunca finda.

A escola, como instituição social, tem o papel de oferecer um ambiente mais controlado e simplificado das situações sociais para guiar a experiência inteligente de solucionar problemas imaginativa e praticamente. O desenvolvimento da capacidade de resolver os problemas sociais, com a participação ativa e livre da vida democrática, depende de um ambiente democrático. A democracia necessita de uma educação que capacite as pessoas na solução inteligente de problemas e não na memorização de conteúdos ou verdades fixas.

A vida democrática é uma forma de vida em que a solução inteligente dos problemas comporta as mais vastas oportunidades, constituindo uma forma de educação moral dos seus membros e reguladora de seus ideais. Torna os indivíduos sensíveis aos problemas sociais e proporciona a investigação pública e cooperativa dos bens sociais, avaliando-os, reajustando ou criando. Prepara para o julgamento de valores. A concepção de um valor está submetida ao processo da concepção de qualquer conceito. Os valores existem na natureza de forma que são experienciados, ou seja, são fruídos, como um bem, num contexto de uso. Valores são fruídos como um bem, quando há esforço deliberado inteligente para encontrar os meios para atingir o fim (bem) desejado, levando-se em conta as conseqüências. Os valores são formados pela continuidade entre fins e meios. Valores são planos de ação, que poderão funcionar bem ou não. São hipotéticos e estão sujeitos ao contínuo aperfeiçoamento e criação. Os bens sociais, quando se tornam problemáticos e conflitantes, requerem a valoração social, ou seja, a prática democrática reflexiva, deliberativa e cooperativa sobre os valores sociais. Os bens sociais são criados por este processo e não por forças estranhas a ela como o egoísmo.

A filosofia da democracia deve ser uma filosofia da educação. A atividade filosófica opera na zona de conflitos e tensões sociais e culturais. A unidade encontra-se na continua reconstrução ou criação dos conceitos, a partir do pluralismo das experiências e da variedade de crenças. 


\section{BIBLIOGRAFIA}

\section{do autor}

BROCK UNIVERSITY. St. Catharines, Ontario, Canada. A John Dewey source page. Logical Conditions of a Scientific Treatment of Morality (1903), 2007. Disponível em <http://www.brocku.ca/MeadProject/Dewey/Dewey_1903.html> Acesso em: 28 abr 2008.

DEWEY, John. A common faith. New Haven: Yale University Press, 1952.

. Como pensamos como se relaciona o pensamento reflexivo com o processo educativo: uma reexposição.Tradução: Haydée Camargo Campos. $4^{\mathrm{a}}$ ed. São Paulo: Nacional, 1979a. Atualidades pedagógicas; vol. 2. 292 p.

Democracia e educação. Tradução: Godofredo Rangel e Anísio Teixeira. São Paulo: Nacional, 1979b. Atualidades pedagógicas; vol. 21. 416p.

Democracy and education. New York: The Macmillan Company, 1944;

Education today. Edited and with a foreword by Joseph Ratner. New York: G.P. Putnam's Sons, 1940. 373p.

Essays in experimental logic. New York: Dover publications, 1953.444p.

Experience and education. New York: The Macmillan Company, 1939a.

Experience and nature. New York: Dover Publications, Inc., 1958. 443p.

Freedom and culture. New York: G. P. Putnam’s Sons, 1939 b.

From absolutism to experimentalism. In: ADAMS, G.P., MONTAGUE, W.P. Contemporary American philosophy, vol. II. New York: The Macmillan Co., 1930. p.12-27.

How we think. A reestatement of the relation of reflective think to the educative process. New York: D.C. Heath \& Co, 1933. 301p.

Human nature and conduct. $9^{\mathrm{a}}$ ed. New York: Henry Holt and Co, 1927.

Human nature and conduct: an introductions to social psychology. New York: Prometheus Books, 2002.

Liberalismo, liberdade e cultura. Tradução de Anísio Teixeira. São Paulo: Nacional, 1970. 261p.

Logic. The theory of inquiry. New York: Henry Hold and Company, 1960. 546p.

Philosophy and civilization. Massachusets: Peter Smith Gloucester, 1968.

Problems of men. New York: Philosophical Library, 1946. 424p.

Psychology. 3a. ed. New York: American Book Company, 1896. 427p. 
Nacional. 1959a.

Reconstrução em filosofia. Tradução: Antônio Pinto de Carvalho. São Paulo: Reconstruction in philosophy. New York: The New American Library, 1954.

The latter works of John Dewey, 1925-1953:1939-1941 (LW) Edited by Jo Ann Boydston. Volume 16. Carbondale: Sounthen Illinois University Press, 1991a. 523p.

The latter works of John Dewey, 1925-1953: 1949-1952. (LW) Edited by Jo Ann Boydston. Volume 16. Carbondale: Sounthen Illinois University Press, $1991 \mathrm{~b}$.

The public and its problems. 12a. ed. Ohio: Ohio University Press, 1991c. 236 p.

The quest for certainty: a study of the relation of knowledge and action. 12 ed., New York: Minton, Balch \& Company, 1929. 318 p.

Vida e Educação. Tradução: Anísio Teixeira. 3a. ed. São Paulo: Nacional., 1959b.

Social Interpretation. In The Philosophical Review. V. 7, No. 6, Nov 1898, p. 629630.

The influence of Darwin on Philosophy and other Essays in contemporary Thought. Bloomington: Indiana University Press, 1965. 309p.

. The school and the society. In: Introduction and notes by Martin S. Dworkin. New York: Columbia University, 1961. p. 33-90.

Theory the moral life. New York: Irvington Publishers, 1996. 179p.

Vida e educação. Tradução de Anísio Teixeira. In: Os Pensadores. São Paulo: Abril Cultural, 1980. V. p.107 - 191.

MCLELlAN, J.A. Applied Psychology. An Introduction to the Principles and Practice of Education. Toronto Copp: Clark Co, Ltd, 1889. 317p.

\section{Geral}

AMARAL, Maria N. C. Pacheco. 1990. Dewey: Filosofia e experiência democrática. São Paulo: Perspectiva/EDUSP.

Dewey: jogo e filosofia da experiência democrática. In: KISHIMOTO, T. M. (org.) O brincar e suas teorias. São Paulo: Pioneira, 1998. p.79-107.

John Dewey: educação e experiência democrática. In: Revista do Clube Humboldt do Brasil. Ed. Responsável: Erwin T. Rosenthal., 1998. N² 2, Ano II, 2002, p. 163-172.

CALVINO, Ítalo. Por que ler os clássicos. São Paulo: Companhia das Letras, 2004. 288p. 
BUTTS, Freeman and CREMIN, Lawrence A. 1959. A history of education in American culture. New York: Henry Holt and Company.

CAMPBELL, James. Undestanding John Dewey: nature and cooperative intelligence Carbondale: Southern Illinois University, 1996. 310p.

COMETTI, J. P.Filosofia sem privilégios. Porto: Edições Asa, 1995.

CUNHA, Marcus Vinicius da. Indivíduo e sociedade no ideário escolanovista: Brasil, 19301960. Tese de doutorado em educação. USP 1992.

GERIBELlO, Wanda Pompeu. Anísio Teixeira: Análise e Sistematização de sua Obra. Tese de Doutoramento, Filosofia da Educação, PUC/SP, 1973.

HABERMAS, Jürgen. Um perfil filosófico-político. Dossiê Habermas. In: Novos estudos Cebrap, 18, 1987. p.77-102.

HOOK, Sidney. John Dewey, philosopher of science and freedom. A symposium. Edited by Sidney Hook, New York: Dial Press Inc., 1950;

IBRI, Ivo A. Kósmos Noetós: A arquitetura metafísica de Charles S. Peirce. São Paulo: Perspectiva e Hólon, 1992. Coleção Estudos. V.130. 138p.

JAMES, William. Pragmatism, a new name for some old way of thinking. New York: Longmans, Green and Co., 1943.

Lidador, 1967.

Pragmatismo e outros ensaios. Tradução de Jorge C. da Silva. Rio de Janeiro:

Pragmatismo e outros ensaios. Tradução de Jorge C. da Silva e Pablo R. Mariconda. São Paulo: Abril Cultural (Os Pensadores), 1974.

MILLS, Wright C. Sociology and pragmatism. 2. ed. Nova York: Oxford University Press, 1966. 346p.

MURARO, Darcísio. A importância do pensar na educação escolar: o pensamento reflexivo como princípio educativo em John Dewey. Dissertação de mestrado. Filosofia da Educação, PUC-SP, 1998. 174p.

PEIRCE, Charles S. Semiótica. 3a . ed. São Paulo: Perspectiva, 2003. 337p.

Semiótica e Filosofia. 9a. ed. São Paulo: Cultrix, 1993. 164p.

1931-1935. Collected Papers of Charles Sanders Peice, Ed. Charles Hartshorne, Paul Weiss e Arthur Burks (org.). Cambridge, Massachusetts, Harvard University Press, 8 vol.

PIATT, Donald A. Dewey logical theory In: Schilpp, Paul A. (Editor). The Philosophy of John Dewey, Chicago: Northwestern University, 1939.

PITOMBO, Maria Isabel Moraes. Conhecimento, valores e educação em John Dewey. São Paulo: Pioneira, 1974. Manuais de Estudo. 172p.

RATNER, Joseph. Dewey`s conception of philosophy. In: Schilpp, Paul A. (Editor) The Philosophy of John Dewey, Chicago: Northwestern University, 1939. p. 49-73. 
RORTY, Richard. Philosophy and the mirror of nature. New York: Princeton University Press, 1979. 1988.

. A filosofia e o espelho da natureza. Tradução de Jorge Pires. Lisboa: Dom Quixote, The linguistic turn. New York: Princeton University Press, 1967.

Consequences of pragmatism. (Essays: 1972-1980). Minneapolis, MN: University of Minnesota Press, 1982.

Objectivity, relativism and truth [Philosophical papers, volume 1]. Cambridge, MA: Cambridge University Press, 1991a..

SASS, Odair. Crítica da razão solitária : a psicologia social segundo George Herbert Mead. Bragança Paulista: Editora Universitária São Francisco, 2004. 303p.

SCHNEIDER, Herbert W. História de la filosofia norteamericana. México: Fondo de Cultura Económica, 1950.

TEIXEIRA, Anísio. A pedagogia de Dewey (esboço da Teoria da Educação de John Dewey)." In: Dewey, John. Vida e educação. Trad. Henry Suzzallo, 4. ed. São Paulo. Ed. Melhoramentos, 1954.

WHITE, Morton G. The origin of Dewey's instrumentalism. Octagon Books: New York, 1977. 161p. 